\title{
Inferência de redes de regulação gênica utilizando o paradigma de crescimento de sementes
}

\author{
Carlos Henrique Aguena Higa
}

\author{
TESE APRESENTADA \\ $\mathrm{AO}$ \\ Instituto De Matemática e Estatística \\ DA \\ Universidade DE SÃo PAUlO \\ PARA \\ OBTENÇÃO DO TÍTULO \\ $\mathrm{DE}$ \\ DOUTOR EM CIÊNCIAS \\ Programa: Ciência da Computação \\ Orientador: Prof. Dr. Ronaldo Fumio Hashimoto
}

Durante o desenvolvimento deste trabalho o autor recebeu auxílio financeiro da CAPES

São Paulo, dezembro de 2011 



\title{
Inferência de redes de regulação gênica utilizando o paradigma de crescimento de sementes
}

\author{
Esta tese contém as correções e alterações \\ sugeridas pela Comissão Julgadora durante a defesa \\ realizada por Carlos Henrique Aguena Higa em 17/2/2012. \\ O original encontra-se disponível no Instituto de \\ Matemática e Estatística da Universidade de São Paulo.
}

Comissão Julgadora:

- Prof. Dr. Ronaldo Fumio Hashimoto (orientador) - IME-USP

- Prof. Dr. André Fujita - IME-USP

- Prof. Dr. Fabrício Martins Lopes - UTFPR

- Prof. Dr. David Corrêa Martins Jr. - UFABC

- Prof. Dr. Júlio Cesar Martins Montes - UNIFESP 
You can't connect the dots looking forward. You can only connect them looking backwards.

So you have to trust that the dots will somehow connect in your future. You have to trust in something: your gut, destiny, life, karma, whatever. Because, believing that the dots will connect down the road will give you the confidence to follow your heart; even when it leads you off the well-worn path.

Steve Jobs 
Aos meus pais. 


\section{Agradecimentos}

Primeiramente, agradeço a Deus e aos bons espíritos por terem me acompanhado ao longo desta caminhada.

Agradeço aos meus pais, Pedro e Neide, por sempre terem feito tudo para que eu pudesse ter uma boa educação. Aos meus irmãos, Ana Paula e Juliano, pelo apoio. À minha namorada, Poliana N. Peres, pelo carinho, apoio e paciência. E agradeço aos demais familiares pelo incentivo.

Ao meu orientador, Ronaldo F. Hashimoto, pela contribuição neste trabalho, sempre me orientando com muita dedicação. Muito obrigado.

Aos professores Roberto Hirata-Jr, Nina Hirata, Roberto Cesar-Jr., Carlos Santos, David Martins-Jr, Fabrício Lopes, Evaldo Oliveira, Ricardo Vêncio, Edward Dougherty e Ulisses BragaNeto, pela oportunidade de aprender muito em nossas conversas, discussões e reuniões.

Aos colegas e colaboradores Tales P. Andrade, Vitor H. Louzada e Henrique Stagni, e aos demais colegas do IME-USP.

Aos colegas de trabalho da FACOM-UFMS, em especial, aos professores Nalvo F. de AlmeidaJr e Marcelo H. de Carvalho.

Aos amigos Álvaro J. P. Franco, Priscila C. Calegari, Francisco E. S. de Araújo, Giovanna D. Mendonça, Ana C. M. Candil, Ana E. L. Naveira, Maria G. Castro, João Burckas, Flávio Yamamoto, Daniel O. Dantas, José E. O. Luna, Rodrigo P. Gondim, Camila A. Cândido, Carla A. Cândido e Andrea T. Nakasato. Obrigado pelo apoio.

À secretaria de pós-graduação do IME-USP.

À CAPES e ao IME-USP, pelo apoio financeiro durante o desenvolvimento deste trabalho. 


\section{Resumo}

HIGA, C. H. A. Inferência de redes de regulação gênica utilizando o paradigma de crescimento de sementes. 2012. 78 f. Tese (Doutorado) - Instituto de Matemática e Estatística, Universidade de São Paulo, São Paulo, 2012.

Um problema importante na área de Biologia Sistêmica é o de inferência de redes de regulação gênica. Os avanços científicos e tecnológicos nos permitem analisar a expressão gênica de milhares de genes simultaneamente. Por "expressão gênica", estamos nos referindo ao nível de mRNA dentro de uma célula. Devido a esta grande quantidade de dados, métodos matemáticos, estatísticos e computacionais têm sido desenvolvidos com o objetivo de elucidar os mecanismos de regulação gênica presentes nos organismos vivos. Para isso, modelos matemáticos de redes de regulação gênica têm sido propostos, assim como algoritmos para inferir estas redes. Neste trabalho, focamos nestes dois aspectos: modelagem e inferência. Com relação à modelagem, estudamos modelos existentes para o ciclo celular da levedura (Saccharomyces cerevisiae). Após este estudo, propomos um modelo baseado em redes Booleanas probabilísticas sensiveis ao contexto, e em seguida, um aprimoramento deste modelo, utilizando cadeias de Markov não homogêneas. Mostramos os resultados, comparando os nossos modelos com os modelos estudados. Com relação à inferência, propomos um novo algoritmo utilizando o paradigma de crescimento de semente de genes. Neste contexto, uma semente é um pequeno subconjunto de genes de interesse. Nosso algoritmo é baseado em dois passos: passo de crescimento de semente e passo de amostragem. No primeiro passo, o algoritmo adiciona outros genes à esta semente, seguindo algum critério. No segundo, o algoritmo realiza uma amostragem de redes, definindo como saída um conjunto de redes potencialmente interessantes. Aplicamos o algoritmo em dados artificiais e dados biológicos de células HeLa, mostrando resultados satisfatórios.

Palavras-chave: redes de regulação gênica, redes Booleanas, inferência de redes, problemas de satisfação de restrições, cadeia de Markov, seleção de características. 


\section{Abstract}

HIGA, C. H. A. Inference of gene regulatory networks using the seed growing paradigm. 2012. 78 f. Tese (Doutorado) - Instituto de Matemática e Estatística, Universidade de São Paulo, São Paulo, 2012.

A key problem in Systems Biology is the inference of gene regulatory networks. The scientific and technological advancement allow us to analyze the gene expression of thousands of genes, simultaneously. By "gene expression" we refer to the mRNA concentration level inside a cell. Due to this large amount of data, mathematical, statistical and computational methods have been developed in order to elucidate the gene regulatory mechanisms that take part of every living organism. To this end, mathematical models of gene regulatory networks have been proposed, along with algorithms to infer these networks. In this work, we focus in two aspects: modeling and inference. Regarding the modeling, we studied existing models for the yeast (Saccharomyces cerevisiae) cell cycle. After that, we proposed a model based on context sensitive probabilistic Boolean networks, and then, an improvement of this model, using nonhomogeneous Markov chain. We show the results, comparing our models against the studied models. Regarding the inference, we proposed a new algorithm using the seed growing paradigm. In this context, a seed is a small subset of genes. Our algorithm is based in two main steps: seed growing step and sampling step. In the first step, the algorithm adds genes into the seed, according to some criterion. In the second step, the algorithm performs a sampling process on the space of networks, defining as its output a set of potentially interesting networks. We applied the algorithm on artificial and biological HeLa cells data, showing satisfactory results.

Keywords: gene regulatory networks, Boolean networks, inference, constraint satisfaction problems, Markov chain, feature selection. 


\section{Sumário}

Lista de Abreviaturas $\quad$ Xv

Lista de Símbolos $\quad$ xvii

Lista de Figuras $\quad$ xix

Lista de Tabelas $\quad$ xxi

1 Introdução 1

1.1 Bioiformática e Biologia Sistêmica . . . . . . . . . . . . . . . . 1

1.2 Redes de regulação gênica . . . . . . . . . . . . . . . . . . . . . . . 2

1.3 Objetivos e contribuição . . . . . . . . . . . . . . . . . . . 3

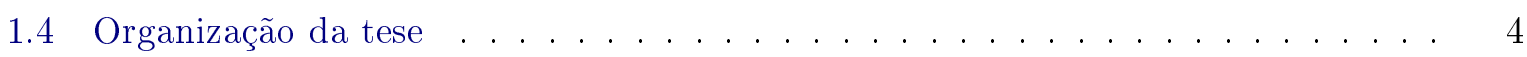

2 Fundamentação teórica $\quad 7$

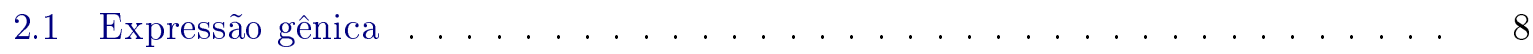

2.1 .1 DNA microarrays . . . . . . . . . . . . . . . . . 9

2.2 Modelos de redes de regulação gênica . . . . . . . . . . . . . . . . . . . . . . . . . . . . . . . . . . . . . . .

2.2 .1 Redes de relevância . . . . . . . . . . . . . . . . . . . . . . . 14

2.2.2 Modelos gráficos Gaussianos . . . . . . . . . . . . . . . . . . . . . . . . . 14

2.2 .3 Equações diferenciais ordinárias . . . . . . . . . . . . . . . . . . . . . 14

2.2 .4 Redes neurais . . . . . . . . . . . . . . . . . . . . . . 15

2.2 .5 Redes Bayesianas . . . . . . . . . . . . . . . . . . . 16

2.2.6 Redes genéticas probabilísticas . . . . . . . . . . . . . . 16

2.3 Modelos Booleanos . . . . . . . . . . . . . . . . . . . . 18

2.3.1 Redes Booleanas . . . . . . . . . . . . . . . . . . . . . . . 19

2.3.2 Redes Booleanas com limiar . . . . . . . . . . . . . . . . . . . . 20

2.3.3 Redes Booleanas com perturbação . . . . . . . . . . . . . . . . . . . 22

2.3.4 Redes Booleanas probabilísticas . . . . . . . . . . . . . . . . . 24

2.4 Algoritmos para inferência de redes . . . . . . . . . . . . . . . . . . 25

2.4.1 Redes de relevância . . . . . . . . . . . . . . . . . . . 26

2.4.2 Modelos gráficos Gaussianos . . . . . . . . . . . . . . . . . . . . 27

2.4 .3 Redes neurais . . . . . . . . . . . . . . . . . . . 27

2.4.4 Equações diferenciais ordinárias . . . . . . . . . . . . . . . . . . . 27 
2.4 .5 Redes Bayesianas . . . . . . . . . . . . . . . . . . . . . 28

2.4 .6 Redes Booleanas . . . . . . . . . . . . . . . . . . . . 28

2.4 .7 Redes genéticas probabilísticas . . . . . . . . . . . . . . 29

2.5 Reconhecimento de padrões . . . . . . . . . . . . . . . . . . . 29

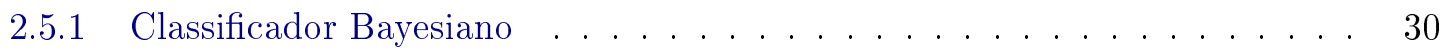

2.5.2 Seleção de características . . . . . . . . . . . . . . . . . . . 31

2.6 Problema de satisfação de restrições . . . . . . . . . . . . . . . 35

2.6.1 Busca de soluções para o CSP . . . . . . . . . . . . . . . . . . 36

2.6.2 Busca de soluções usando backtracking . . . . . . . . . . . . . . 37

2.6.3 Propagando informação através de restrições . . . . . . . . . . . . . . 39

3 O ciclo celular da levedura $\quad 41$

3.1 Ciclo celular . . . . . . . . . . . . . . . . . . . . . . . 41

3.2 Modelo determinístico . . . . . . . . . . . . . . . . . . . . 42

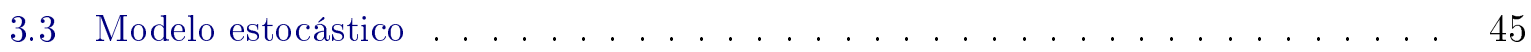

4 Modelagem do ciclo celular $\quad 49$

4.1 Modelo cPBN . . . . . . . . . . . . . . . . . . . . . . 49

4.2 Modelo NHMC . . . . . . . . . . . . . . . . . . . . . . . 50

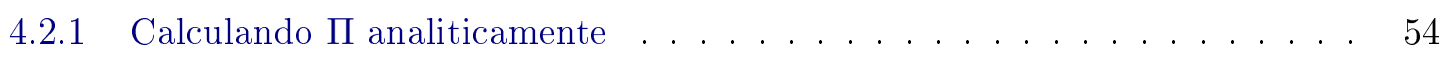

4.2 .2 Resultados . . . . . . . . . . . . . . . . . . . . . 58

5 Inferência de redes de regulação gênica $\quad 63$

5.1 Utilizando CoD para inferir relações entre genes . . . . . . . . . . . . . . . . . 64

$5.1 .1 \quad$ CoD estacionário . . . . . . . . . . . . . . . . . . . . . 64

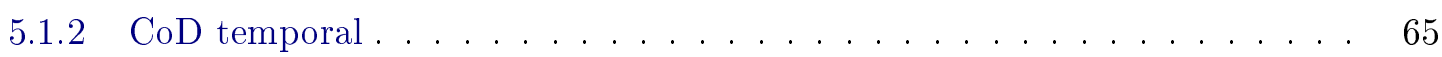

5.2 Gerando redes consistentes usando CSP . . . . . . . . . . . . . . . . . . 69

$5.2 .1 \quad$ Formulando o CSP . . . . . . . . . . . . . . . . . . . . . 69

5.2 .2 Gerando restrições do CSP . . . . . . . . . . . . . . . . 70

5.2 .3 Analisando as conexões entre os genes . . . . . . . . . . . . . . 75

5.3 Algoritmo baseado em crescimento de semente . . . . . . . . . . . . . . . . . . 81

5.3 .1 Passo de amostragem . . . . . . . . . . . . . . . 82

$5.3 .2 \quad$ Passo de crescimento de semente . . . . . . . . . . . . . 85

5.3 .3 Resultados . . . . . . . . . . . . . . . . . . . 89

6 Conclusões $\quad 105$

6.1 Considerações finais . . . . . . . . . . . . . . . . . . . . . . . 105

6.2 Sugestões para pesquisas futuras . . . . . . . . . . . . . . 107

$\begin{array}{lr}\text { A Resultados - células HeLa } 1 & 109\end{array}$

B Resultados - células HeLa $2 \quad 113$

$\begin{array}{ll}\text { C Trabalhos produzidos } & 117\end{array}$ 
Referências Bibliográficas

Índice Remissivo 


\title{
Lista de Abreviaturas
}

\author{
API Application programming interface \\ BN Redes Booleanas (Boolean networks) \\ BNp Redes Booleanas com perturbação (Boolean networks with perturbation) \\ BPTT Backpropagation through time \\ cDNA DNA complementar (complementary DNA) \\ CoD Coeficiente de determinação (Coefficient of determination) \\ cPBN PBN sensíveis ao contexto (context sensitive PBN) \\ CSP Problemas de satisfação de restrições (Constraint satisfaction problems) \\ DAG Grafo acíclico dirigido (Directed acyclic graph) \\ DBN Redes Bayesianas dinâmicas (Dynamic Bayesian networks) \\ DNA Ácido desoxirribonucleico (Deoxyribonucleic acid) \\ DPI Data processing inequality \\ EDO Equações diferenciais ordinárias \\ EFD Equal frequency discretization \\ EM Expectation-Maximization \\ EWD Equal width discretization \\ FP Falso negativo (False negative) \\ FPR Taxa de falso negativo (False negative rate) \\ GGM Modelos gráficos Gaussianos (Graphical Gaussian models) \\ GRN Redes de regulação gênica (Gene regulatory networks) \\ GT Ground truth \\ IFFS Improved Forward Floating Selection \\ MCMC Monte Carlo Markov Chain \\ mRNA Ácido ribonucleico mensageiro (Messenger ribonucleic acid) \\ MRV Menores valores restantes (Minimum remaining values) \\ NHMC Cadeia de Markov não homogênea (Nonhomogeneous Markov chain) \\ PBN Redes Booleanas probabilísticas (Probabilistic Boolean networks) \\ PCR Reação em cadeia da polimerase (Polymerase chain reaction) \\ PGN Redes genéticas probabilísticas (Probabilistic genetic networks) \\ RNA Ácido ribonucleico (Ribonucleic acid) \\ RNAP RNA polimerase \\ RNN Rede neural recorrente (Recurrent neural network)
}


ROC Receiver operating characteristic

SAGE Serial analysis of gene expression

SBS Sequential Backward Selection

SFFS Sequential Forward Floating Selection

SFS Sequential Forward Selection

snRNA Small nuclear RNA

tBN Redes Booleanas com limiar (thresholded Boolean networks)

tCoD Coeficiente de determinação temporal (Temporal coefficient of determination)

TP Verdadeiro positivo (True positive)

TPR Taxa de verdadeiro positivo (True positive rate)

UTR Região não traduzida (Untranslated region) 


\section{Lista de Símbolos}

\begin{tabular}{ll}
$A$ & Matriz de regulação \\
$a_{i, j}$ & Aresta de regulação do gene $x_{j}$ para $x_{i}$ \\
$\mathcal{I}_{i}(t)$ & Input no gene $x_{i}$ no tempo $t$ \\
$S$ & Semente (subconjunto pequeno) de genes inicial \\
$\mathbf{T}$ & Dados temporais \\
$s(t)$ & Uma amostra no tempo $t$ \\
$X$ & Conjunto de genes \\
$x_{i}$ & Gene de uma rede \\
$f_{i}$ & Função de regulação para o gene $x_{i}$ \\
$\mathbf{x}_{i}(t)$ & Estado de uma rede no tempo $t$ \\
$k_{i}$ & Conectividade de entrada do gene $x_{i}$ \\
$E[\cdot]$ & Esperança \\
$p$ & Probabilidade de perturbação \\
$P$ & Matriz de transição de estados \\
$Y$ & Gene alvo \\
$\mathbf{Z}$ & Conjunto de genes preditores \\
$\theta$ & Coeficiente de determinação \\
$J$ & Função critério \\
$\Pi$ & Distribuição de probabilidade estacinária \\
$\alpha$ & Parâmetro de estocasticidade \\
$\beta$ & Parâmetro de estocasticidade (temperatura) \\
$\gamma$ & Número de matrizes da NHMC \\
$O$ & Matriz nula \\
$\mathcal{K} e r(\cdot)$ & Kernel ou espaço nulo de uma matriz \\
$\mathcal{Z}$ & Conjunto de verdadeiros genes preditores \\
$\mathcal{L}$ & Limiar \\
$V$ & Conjundo de variáveis de um CSP \\
$\mathcal{A}$ & Atrator \\
$\mathcal{B}$ & Bacia de atração \\
$H$ & Entropia \\
$x_{c}$ & Gene candidato \\
\hline &
\end{tabular}




\section{Lista de Figuras}

2.1 Início da transcrição. . . . . . . . . . . . . . . . . . . . . . . . . 8

2.2 Transcrição em andamento. . . . . . . . . . . . . . . . 8

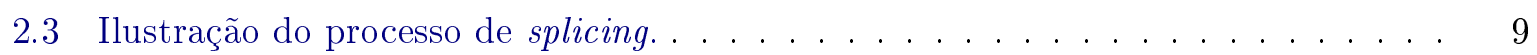

2.4 Experimento de microarray. . . . . . . . . . . . . . . . . . . . 11

2.5 Visão esquemática de uma rede de regulação gênica. . . . . . . . . . . . . . . . 13

2.6 Um exemplo simples de redes Bayesianas Dinâmicas. . . . . . . . . . . . . . 17

2.7 Diagrama de transição de estados de uma BN. . . . . . . . . . . . . . . . . 20

2.8 Representação gráfica da interação entre os quatro genes. . . . . . . . . . . . . . 21

2.9 Diagrama de transição de estados de uma tBN. . . . . . . . . . . . . . . . . . . 22

2.10 Estrutura básica de uma PBN. . . . . . . . . . . . . . . . . 25

2.11 Fluxograma do algoritmo IFFS. . . . . . . . . . . . . . . . . . 35

2.12 Exemplo de um grafo de restrições para um CSP. . . . . . . . . . . . . . . . 37

2.13 Aplicação do backtracking. . . . . . . . . . . . . . . . . . . . . 38

2.14 Grafo de restrições para um problema de coloração de mapas. . . . . . . . . . . . 39

3.1 Fases do ciclo celular. . . . . . . . . . . . . . . . . . . . . . . . . 42

3.2 Rede do ciclo celular da levedura. . . . . . . . . . . . . . . . . . . . 43

3.3 Diagrama de transição de estados da rede do ciclo celular. . . . . . . . . . . . . . 44

3.4 Probabilidade estacionária do estado $G_{1}^{*} \ldots \ldots \ldots \ldots \ldots$. . . . . . 47

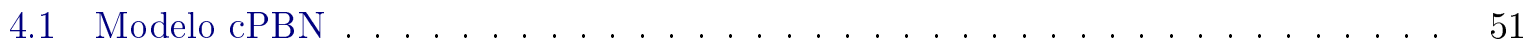

4.2 Gráfico da probabilidade estacionária do estado $\mathrm{G}_{1} \ldots \ldots \ldots \ldots \ldots$

4.3 Probabilidade dos estados da via do ciclo celular. . . . . . . . . . . . . . . 52

4.4 Comparação dos modelos cPBN e Zhang . . . . . . . . . . . . . . . 53

4.5 Probabilidade dos estados da via . . . . . . . . . . . . . . . 54

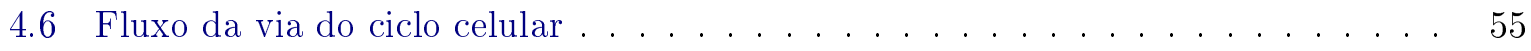

4.7 Matriz do modelo NHMC . . . . . . . . . . . . . . . . . . 56

4.8 Probabilidade estacionária do estado $\mathrm{G}_{1}$ no modelo NHMC. . . . . . . . . . . . 59

4.9 Probabilidade estacionária dos estados da via do ciclo celular. . . . . . . . . . . . 60

4.10 Probabilidade estacionária dos estados atratores. . . . . . . . . . . . . . . 61

5.1 CoDs calculados para conjuntos preditores de tamanho um. . . . . . . . . 65

5.2 CoDs calculados para conjuntos preditores de tamanho dois. . . . . . . . . . . 66

5.3 Um exemplo de gráfico de barras. . . . . . . . . . . . . . . . . . . 76 
5.4 Gráfico de barras para os genes Cln3, MBF, SBF, Cln1 e Cdh1 . . . . . . . . . 77

5.5 Gráfico de barras para os genes: Swi5, Cdc20, Clb5, Sic1, Clb1 e Mcm1. . . . . . 78

5.6 Conexões determinadas e parcialmente determinadas. . . . . . . . . . . . 78

5.7 Taxa de verdadeiro positivo para os maiores ranks calculados. . . . . . . . . . . . 79

5.8 Gráfico de barras para as conexões de entrada do gene CDC2 . . . . . . . . . 80

5.9 Histograma das entropias, considerando um gene $h u b$ aleatório. . . . . . . . . . 91

5.10 Espaço ROC para o experimento com dados artificiais. . . . . . . . . . . . . . . 92

5.11 Rede inferida representada por um dos melhores pontos no espaço ROC. . . . . . 92

5.12 O diagrama de transição de estados da rede da Fig. 5.11 . . . . . . . . . . . . . 93

5.13 Histograma das entropias calculadas sem considerar um gene hub. . . . . . . . 93

5.14 Rede inferida sem considerar um gene $h u b \ldots \ldots \ldots \ldots$. . . . . . . . . 94

5.15 Diagrama de transição de estados da rede da Fig. 5.14 . . . . . . . . . . . . . 94

5.16 Histograma das entropias, considerando o gene CDC2 como hub, para os dados de células HeLa. . . . . . . . . . . . . . . . . . . . . . 96

5.17 Rede possuindo a menor entropia considerando o gene CDC2 como hub. . . . . . 97

5.18 Diagrama de transição de estados da rede da Fig. 5.17 . . . . . . . . . . . . . . . . . . . . . . . . . . . . .

5.19 Rede possuindo a maior razão $L / T$. . . . . . . . . . . . . . . . . . . . . 99

5.20 Diagrama de transição de estados da rede da Fig. 5.19 . . . . . . . . . . . . 100

5.21 Histograma das entropias, sem considerar um gene $h u b$, para os dados de células HeLa. . . . . . . . . . . . . . . . . . . . . . . 100

5.22 Rede inferida possuindo a maior razão $L / T$, sem considerar um gene hub. . . . . 101

5.23 Diagrama de transição de estados da rede da Fig. 5.22 . . . . . . . . . . . . . . 101

5.24 Rede inferida possuindo a menor entropia, sem considerar um gene hub. . . . . . 102

A.1 Gráfico de barras para os genes CCNE1 e E2F1. . . . . . . . . . . . . . . 109

A.2 Gráfico de barras para os genes CDC6, PCNA, RFC4, DHFR, RRM2 e RAD51. . 110

A.3 Gráfico de barras para os genes CDC2, TOP2A, CCNF, CCNA2, STK15 e BUB1. 111

A.4 Gráfico de barras para os genes CCNB1, PLK, PTTG1, RAD21, VEGFC e CDKN3.112

B.1 Gráfico de barras para os genes CCNE1 e E2F1. . . . . . . . . . . . . . . . 113

B.2 Gráfico de barras para os genes CDC6, PCNA, RFC4, DHFR, RRM2 e RAD51. . 114

B.3 Gráfico de barras para os genes CDC2, TOP2A, CCNF, CCNA2, STK15 e BUB1. 115

B.4 Gráfico de barras para os genes CCNB1, PLK, PTTG1, RAD21, VEGFC e CDKN3.116 


\section{Lista de Tabelas}

2.1 Os possíveis produtos de Kmeans e CoKmeans são mostrados nesta tabela, para

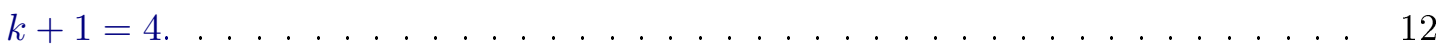

2.2 Funções Booleanas. . . . . . . . . . . . . . . . . . . . . . . . . . 19

2.3 Função XOR para determinar o valor de $x_{1}(t+1) \ldots \ldots \ldots \ldots \ldots \ldots$

3.1 Os sete atratores da rede do ciclo celular da levedura. . . . . . . . . . . . . . . 43

3.2 Evolução temporal dos estados do ciclo celular. . . . . . . . . . . . . . . . . . . 44

3.3 Os nove atratores do modelo estocástico. . . . . . . . . . . . . . . . . . 45

3.4 Estados com a segunda maior probabilidade de transição a partir do estado $\mathrm{G}_{1}$

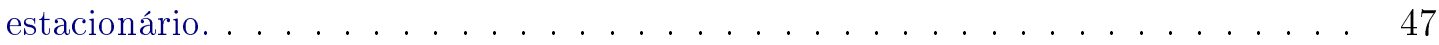

5.1 Tabela de próximos estados. . . . . . . . . . . . . . . 67

5.2 Tabela contendo valores de tCoDs. . . . . . . . . . . . . . . . . 68

$5.3 T / T_{c}$ para cada gene alvo e $k=1, \ldots, 6 \ldots \ldots \ldots \ldots \ldots$

5.4 Um exemplo de dados temporais contendo 5 amostras e 4 genes. . . . . . . . . . . 71

5.5 Restrições geradas a partir da análise de pares de estados. . . . . . . . . . . . . 72

5.6 Restrições obtidas observando pares de transições. . . . . . . . . . . . . . . . . . 74

5.710 maiores ranks usando dados artificiais. . . . . . . . . . . . . . . . 76

5.8 Genes considerados nos dados de células HeLa. . . . . . . . . . . . . . . . . . 79

5.9 Os 10 maiores ranks calculados com os dados de células HeLa. . . . . . . . . . . . 80

5.10 Os 10 maiores ranks calculados com os dados de células HeLa, adicionando conhecimento biológico. . . . . . . . . . . . . . . . . . . 81

5.11 Matriz de confusão. . . . . . . . . . . . . . . . . . . . . . . . 90

5.12 A matriz de confusão da rede apresentada na Fig. 5.11 . . . . . . . . . . . . . . 91

5.13 Matriz de confusão da rede da Fig. 5.14 . . . . . . . . . . . . . . . . . . . 94

5.14 Tabela resumindo alguns resultados com relação a FPR e TPR. . . . . . . . . . . 95

5.15 Dados discretizados das células HeLa. . . . . . . . . . . . . . . . . 95

5.16 Similaridades obtidas pelo algoritmo de crescimento de semente anterior e o algoritmo proposto, para cada uma das 20 sementes testadas. . . . . . . . . . . . . 103 


\section{Capítulo 1}

\section{Introdução}

\subsection{Bioiformática e Biologia Sistêmica}

Em junho de 2000, Francis Collins e Craig Venter, ao lado do então presidente dos Estados Unidos, Bill Clinton, anunciaram na Casa Branca que o primeiro esboço do genoma humano estava concluído. Oito messe depois, a revista Nature publicou o trabalho da equipe de Collins, o Human Genome Project (IHGSC, 2001), enquanto que a Science publicava o trabalho da Celera Genomics (Venter, 2001), a empresa de Venter. Houve uma certa expectativa de que a cura de diversas doenças, como o câncer, estaria próxima. Não foi exatamente o que aconteceu, mas não podemos negar que houve um grande avanço na ciência e, percebemos que ainda existe muito trabalho a ser feito.

Antes mesmo do sequenciamento do genoma humano, o termo Bioinformática foi introduzido por Paulien Hogeweg e Ben Hesper em 1978, definido como sendo "the study of informatic process in biotic systems" (Hogeweg, 2011). Antes disso, alguns trabalhos pioneiros em Biologia Teórica já existiam. Por exemplo, em 1972, uma série de livros chamada Towards a Theoretical Biology, editada por Conrad Hal Waddington (Waddington, 1972) já havia aparecido, e Stuart Kauffman já havia apresentado seu trabalho em redes Booleanas aleatórias como modelos de regulação de transcrição gênica, em 1969 (Kauffman, 1969). A área de Biologia Sistêmica integra conhecimentos da biologia para entender como as partes de um organismo ou célula (genes, proteínas, tecidos, etc.) trabalham em conjunto para garantir a sobrevivência da célula. Em outras palavras, estudamos organismos biológicos em nível de sistema ao invés de estudarmos seus componentes individualmente. Segundo Hiroaki Kitano, o estudo em nível de sistema pode ser derivado a partir de quatro propriedades (Kitano, 2002):

1. Estrutura do sistema: inclui a rede de interações gênicas e vias metabólicas, assim como os mecanismos pelos quais tais interações modulam as propriedades físicas de estruturas intra e multicelulares.

2. Dinâmica do sistema: como o sistema se comporta no decorrer do tempo sob diversas condições;

3. Controle: mecanismos para controlar o estado de uma célula para evitar um comportamento indesejável e fornecer potenciais alvos terapêuticos para tratamento de doenças; 
4. Projeto: estratégias para modificar e construir sistemas biológicos com propriedades desejadas.

Este trabalho concentra-se nos dois primeiros itens acima, como descrito a seguir.

\subsection{Redes de regulação gênica}

Devido ao avanço de tecnologias high-throughput, hoje é possível analisar a expressão de uma grande quantidade de genes simultaneamente. O termo "expressão gênica" se refere ao transcriptoma de um organismo. Uma fonte de dados de expressão gênica muito utilizada é a tecnologia de DNA microarrays (Schena et al., 1995; Shalon et al., 1996). Existem outros tipos de dados, como por exemplo, ChIP (Das et al., 2004) (Chromatin immunoprecipitation), ChIP-chip (ChIP combinado com microarray) (Buck e Lieb, 2004; Zheng et al., 2007) e análise de interação proteína-proteína (Herzberg et al., 2007; Selbach e Mann, 2006). Além disso, a maneira como analisamos o transcriptoma foi aprimorada com uma nova tecnologia conhecida como RNASeq (Wang et al., 2009). Além de expressões gênicas (transcriptomics), outros campos "omics" têm evoluído, como proteomics (proteínas) e metabolomics (metabólitos). Lidar com estes dados têm sido um grande desafio em diversas áreas, entre elas, a Biologia Sistêmica.

Em Biologia Sistêmica, um problema bastante abordado é o da inferência de redes de regulação gênica (GRN - gene regulatory networks) a partir de dados de expressão gênica. Em geral, um modelo matemático que explique as relações entre os genes do sistema biológico é proposto para auxiliar o processo de inferência. Existem modelos estáticos ou dinâmicos, contínuos ou discretos, lineares ou não-lineares, determinísticos ou estocásticos (Hache et al., 2009). Entre os modelos mais populares podemos citar primeiramente as redes Booleanas, ou BNs (Boolean networks) propostas por Kauffman (Kauffman, 1969). Temos também as redes Booleanas probabilisticas (probabilistic Boolean Networks - PBN) propostas por Shmulevich (Shmulevich et al., 2002a) e as redes Bayesianas (Friedman et al., 2000). Existem modelos baseados em equações diferenciais ordinárias (Goodwin, 1963) que foram sugeridos décadas atrás e modelos não lineares como $S$ systems (Savageau, 1970). Existem ainda outros modelos e uma revisão sobre modelos de redes de regulação gênica pode ser vista em (Hecker et al., 2009) e (Karlebach e Shamir, 2008).

Neste trabalho estaremos focando a nossa atenção nos modelos discretos, mais precisamente nos modelos Booleanos. Em tais modelos, a expressão gênica de um gene é representada apenas por dois valores: 0 (ativo) e 1 (inibido). Modelos Booleanos são mais "grossos" se comparados com os modelos contínuos, havendo desvantagens e vantagens sobre os últimos. Uma desvantagem, bastante apontada, é a perda de informação decorrente da discretização dos dados. Por outro lado, modelos contínuos são mais detalhados mas necessitam de uma quantidade maior de amostras para serem inferidos. Uma discussão a respeito de modelagem contínua ou discreta pode ser vista em (Ivanov e Dougherty, 2006). Modelos discretos têm sido aplicados com sucesso, por exemplo, para modelar o desenvolvimento da planta Arabidopsis thaliana (Espinosa-Soto et al., 2004), o ciclo celular da levedura, Saccharomyces cerevisiae (Li et al., 2004) e do parasita causador da malária, (Plasmodium falciparum) (Barrera et al., 2007), entre outros.

O problema da inferência ou engenharia reversa de GRN a partir de dados de expressão 
gênica consiste em elucidar as interações entre genes/proteínas, utilizando um modelo matemático. Em outras palavras, queremos descobrir qual a rede de regulação gênica que gerou os dados de expressão gênica. A inferência de GRN é motivada pela premissa de que um estado funcional de um organismo é amplamente determinado pela expressão gênica (baseado no dogma central da Biologia Molecular) (D'Haeseleer et al., 1999). As redes de regulação gênica possuem um papel importante em processos biológicos, incluindo a diferenciação celular, metabolismo, ciclo celular e transdução de sinal. O entendimento da dinâmica destas redes pode ajudar a esclarecer os mecanismos de doenças que ocorrem quando estes processos celulares estão desregulados (Karlebach e Shamir, 2008).

A inferência de redes a partir de expressões gênicas é um problema inverso. Em geral, este problema é mal posto (ill-posed), no sentido de que podem existir várias redes capazes de gerar os dados observados (também pode ocorrer de não existir uma rede). Isso torna o problema bastante complexo, uma vez que os dados disponíveis são limitados. Em alguns casos, apenas algumas dezenas de amostras de expressão gênica estão disponíveis. Para auxiliar o processo de inferência, diversas metodologias têm sido utilizadas, baseadas em diversas áreas de estudo, como Reconhecimento de Padrões, Inteligência Artificial, Teoria da Informação, Estatística, entre outros.

Neste trabalho, como foi mencionado anteriormente, estamos utilizando modelos Booleanos e, além disso, o processo de inferência é baseado no paradigma de crescimento de semente. Neste contexto, referimos a uma semente como um conjunto de genes relacionados entre si ou que existam hipóteses que nos levam a crer que estes genes estão fortemente relacionados no processo biológico em questão. Alguns algoritmos utilizando este paradigma foram propostos, o primeiro por (Hashimoto et al., 2004), que utiliza uma força de conexão entre os genes, que pode ser definida a partir do coeficiente de determinação ou CoD (Dougherty et al., 2000; Hashimoto et al., 2003); outro algoritmo proposto por (Peña et al., 2005), que pode ser visto como uma extensão do primeiro e utiliza redes Bayesianas. Em (Lima, 2009) foi proposto um algoritmo baseado em crescimento por camadas, onde uma força de conexão também é utilizada para crescer a semente.

\subsection{Objetivos e contribuição}

O principal objetivo deste trabalho é o desenvolvimento de um algoritmo para a inferência de redes de regulação gênica, a partir de dados temporais de expressão gênica. Durante o desenvolvimento deste trabalho, estudamos dois pontos: modelagem e inferência de GRN. Parte do trabalho realizado durante o doutorado foi voltado à modelagem do ciclo celular da levedura. Primeiro estudamos um modelo determinístico do ciclo celular, proposto em (Li et al., 2004) e um modelo estocástico (Zhang et al., 2006). Baseando nestes modelos, propomos um modelo utilizando redes Booleanas probabilísticas sensiveis ao contexto (Seção 2.3.4), e posteriormente, um aprimoramento que pode ser visto como uma cadeia de Markov não homogênea.

Na parte de inferência de GRN, utilizamos o modelo de redes Booleanas com limiar e o paradigma de crescimento de semente de genes. Com este paradigma, o algoritmo de inferência proposto possui dois passos: o passo de crescimento da semente e o passo da inferência. No passo 
de crescimento, o algoritmo adiciona genes à semente inicial, até que uma certa quantidade de genes tenha sido adicionada. No passo de inferência, o algoritmo realiza um processo de amostragem, selecionando redes que podem ser biologicamente significantes.

O passo de crescimento da semente pode ser visto como um problema de seleção de características, onde as características são os genes. Assim, estudamos as propriedades das redes Booleanas com limiar e formulamos uma função critério para selecionar os genes e crescer a semente. Além disso, para encontrar redes Booleanas que expliquem os dados de expressão gênica, utilizamos uma abordagem baseada em problemas de satisfação de restrições, ou CSP (constraint satisfaction problems).

Para validar o algoritmo proposto, utilizamos dados de expressão gênica artificiais gerados a partir de uma rede conhecida (ground-truth). Comparamos as redes inferidas com a rede conhecida para avaliar o desempenho do algoritmo. Também utilizamos dados biológicos de células HeLa. Neste caso, buscamos por informações contidas na literatura com o objetivo de validar as redes inferidas.

\subsection{Organização da tese}

O restante desta tese está organizada nos seguintes capítulos:

- Capítulo 2 - Fundamentação teórica: neste capítulo estaremos apresentando os conceitos teóricos necessários para a leitura do texto. Além disso, apresentamos uma breve revisão bibliográfica sobre modelos e algoritmos de inferência de redes de regulação gênica. Os modelos Booleanos são apresentados com mais detalhes, pois foram utilizados neste trabalho. Também discutimos brevemente o problema de seleção de características e o problema de satisfação de restrições (CSP). Algoritmos para lidar com estes problemas foram utilizados neste trabalho;

- Capítulo 3 - O ciclo celular da levedura: apresentamos os aspectos biológicos do ciclo celular da levedura Saccharomyces cerevisiae, juntamente com dois modelos matemáticos para este processo. Também trata-se de uma revisão bibliográfica, porém, como estes modelos foram utilizados extensivamente durante o trabalho, eles são apresentados com detalhes neste capítulo. O primeiro, é um modelo determinístico; o segundo, visto como uma extensão do primeiro, inclui parâmetros para modelar a estocasticidade, naturalmente presente em organismos biológicos;

- Capítulo 4 - Modelagem do ciclo celular: neste capítulo apresentamos a nossa proposta para a modelagem do ciclo celular. Começaremos com um modelo baseado em redes Booleanas probabilísticas sensiveis ao contexto, e depois, um aprimoramento deste modelo, que pode ser visto como uma cadeia de Markov ergódica não homogênea. Comparamos nossos modelos com os modelos apresentados no Capítulo 3, apresentando os resultados obtidos;

- Capítulo 5 - Inferência de redes de regulação gênica: o algoritmo de inferência de GRN, baseado no paradigma de crescimento de semente de genes proposto, é apresentado 
neste capítulo. Primeiro, apresentamos uma abordagem baseada em problemas de satisfação de restriçôes para analisar interações entre genes. Esta mesma abordagem é utilizada no algoritmo de inferência, que possui dois passos principais: passo de crescimento de semente e passo de amostragem. No primeiro passo, utilizamos algoritmos de seleção de características; descrevemos como a função critério utilizada nestes algoritmos foi projetada. No segundo passo, selecionamos algumas redes inferidas, que são apresentadas como a saída do algoritmo. Validamos o algoritmo utilizando dados artificiais, gerados por um modelo do ciclo celular apresentado no Capítulo 3. Também aplicamos o algoritmo em dados biológicos de células HeLa. Neste caso, realizamos uma busca na literatura pelas interações gênicas inferidas. Apresentamos os resultados ao final deste capítulo.

- Capítulo 6 - Conclusões: nossas conclusões, considerações finais e perspectivas para trabalhos futuros são colocadas neste capítulo. 


\section{Capítulo 2}

\section{Fundamentação teórica}

Neste capítulo apresentaremos a fundamentação teórica e revisão bibliográfica necessária para a leitura do trabalho a ser apresentado no próximo capítulo. Como este texto trata-se de uma tese de doutorado em Ciência da Computação onde a subárea de atuação é a Bioinformática, será apresentado tópicos na área de ciências exatas e biológicas:

- Expressão gênica (Seção 2.1): esta seção se faz necessária para entendermos de onde e como são obtidos os dados utilizados neste trabalho. Apresentaremos o conceito de $e x$ pressão gênica e como dados de expressão gênica são obtidos. Apresentamos também um algoritmo para a discretização de dados de expressão gênica utilizado neste trabalho;

- Modelos de redes de regulação gênica (Seção 2.2): apresentaremos o conceito de redes de regulação gênica e alguns modelos matemáticos populares para representar tais redes, como modelos baseados em equações diferenciais ordinárias e redes Bayesianas, que são frequentemente encontrados na literatura. Estes modelos são apresentamos a título de informação; o leitor pode, se desejar, ir diretamente para a Seção 2.3, na qual iremos apresentar os modelos Booleanos, utilizados neste trabalho;

- Modelos Booleanos (Seção 2.3): nesta seção apresentamos com mais detalhes os modelos Booleanos (determinísticos e estocásticos), incluindo o modelo de redes Booleanas com limiar, utilizado neste trabalho. Veremos características e exemplos destas redes;

- Algoritmos para inferência de redes (Seção 2.4): esta seção também se trata de uma revisão bibliográfica, onde alguns algoritmos propostos para inferência de redes de regulação gênica são apresentados brevemente. Os algoritmos apresentados são baseados nos diversos modelos apresentados nas Seções 2.2 e 2.3. Não temos a intenção de listar todos os algoritmos existentes e, o leitor pode, se desejar, dirigir-se à Seção 2.5.2 diretamente.

- Reconhecimento de padrões (Seção 2.5): em análise de sinais genômicos, uma grande variedade de problemas envolve reconhecimento de padrões. Nesta seção, apresentamos o problema de classificação e de seleção de características. Algoritmos para o problema de seleção de características são utilizados como uma ferramenta para lidar com o problema proposto neste trabalho. Apresentaremos formalmente o problema de seleção de características e algoritmos utilizados para resolver este problema; 
- Problema de satisfação de restrições (Seção 2.6): parte do problema proposto neste trabalho foi modelado como um problema de satisfação de restrições, estudado nesta seção. Veremos a definição formal deste problema e métodos para encontrar soluções.

\subsection{Expressão gênica}

Expressão gênica é o processo pelo qual a informação codificada por um gene é utilizada para a síntese do produto gênico final, que geralmente é uma proteína (em alguns casos, o produto final pode ser um RNA funcional). Este processo é realizado por todas as formas de vida conhecidas - procariotos e eucariotos - para que os organismos se mantenham vivos. O processo ocorre em passos: transcrição, splicing do RNA, tradução, e modificação pós-traducional da proteína.

Uma molécula de DNA é formada por duas fitas (cadeias) de açúcares e fosfatos, onde existe uma base nitrogenada ligada à molécula de açúcar. Entre as possíveis bases temos a adenina (A), citosina (C), guanina (G) e timina (T). Cada fita possui duas pontas, $5^{\prime}$ e $3^{\prime}$, orientadas em direção antiparalela. A fita codificante (coding strand) armazena a informação genética, enquanto a fita molde (template strand) serve como modelo para a produção de RNA. Nos procariotos, o início da transcrição ocorre com a ligação do RNA polimerase (RNAP) à região promotora, auxiliada por um fator de transcrição conhecido como fator sigma. Nos eucariotos a transcrição é um pouco mais complexa. Existem vários tipos de RNAP (de I a V), dependendo do RNA a ser sintetizado (RNA mensageiro, micro RNA, RNA transportador, entre outros). Além disso, o início da transcrição necessita de um conjunto de fatores de transcrição. A Fig. 2.1 ilustra esta situação.

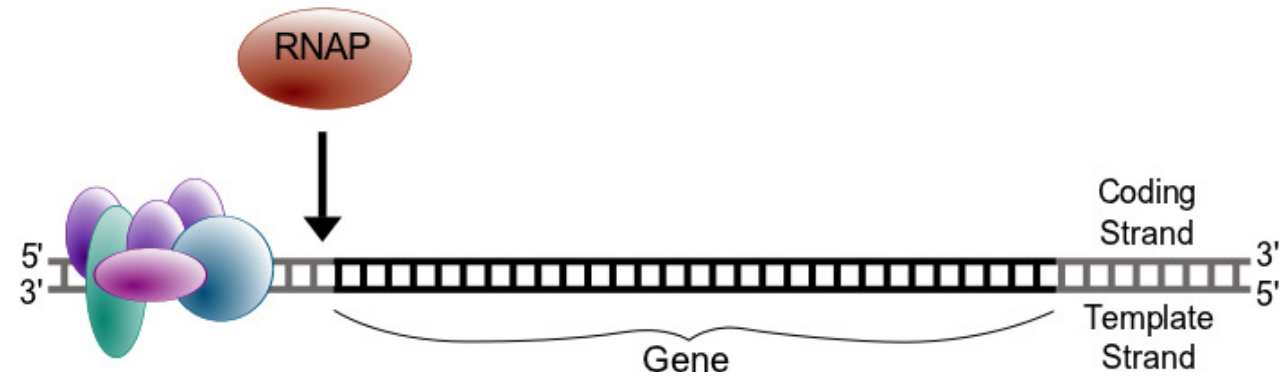

Figura 2.1: Início da transcrição em um eucarioto. Fonte: Wikipedia (2011c).

No passo seguinte o RNAP adiciona um nucleotídeo por vez na fita de RNA sendo criada. Com relação aos nucleotídeos do DNA, a diferença é que no RNA a uracila (U) substitui a timina (T). Além disso, o açúcar presente no DNA é a desoxirribose, enquanto que no RNA é a ribose. A fita de RNA sendo criada é complementar à fita molde no sentido $3^{\prime} \rightarrow 5^{\prime}$, que por sua vez é complementar à fita codificante $5^{\prime} \rightarrow 3^{\prime}$ do DNA (Fig. 2.2).

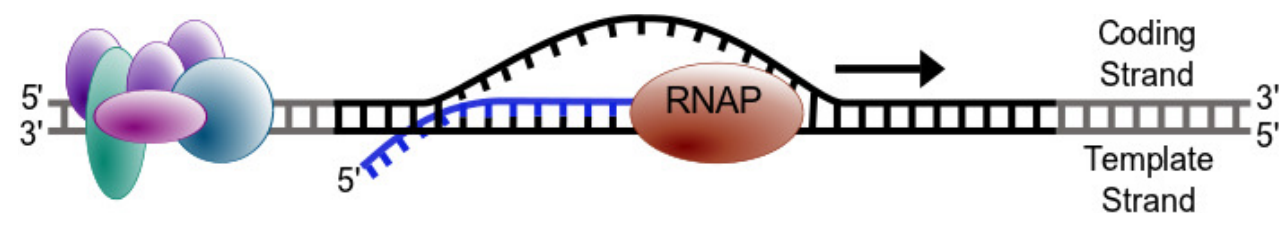

Figura 2.2: Transcrição em andamento. Fonte: Wikipedia (2011c). 
No caso de procariotos, o RNA transcrito é o mRNA (RNA mensageiro) pronto para o processo de tradução. Em eucariotos este RNA é, na verdade, o pre-mRNA que passa por uma série de modificações para se tornar um mRNA maduro. Uma modificação importante que ocorre é conhecida como splicing. Geralmente, o pre-mRNA é formado por segmentos alternados de íntrons e éxons. A palavra intron é derivada do termo intragenic region. O splicing consiste em remover os íntrons e unir os éxons, formando o mRNA (Fig. 2.3). Para realizar o splicing a célula conta com o spliceossomo, um complexo de snRNA (small nuclear RNA) e subunidades proteicas, que faz a remoção dos íntrons. Assim, quando um gene é transcrito, dizemos que este gene está expresso, caso contrário ele está inibido.

pre-mRNA

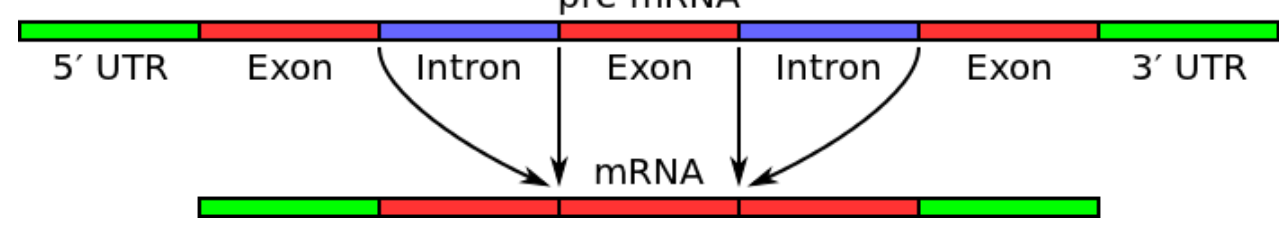

Figura 2.3: Ilustração do processo de splicing. UTR é uma região que não é traduzida (untranslated region). Os éxons formam a região codificante no mRNA. Fonte: Wikipedia (2011b).

Após o splicing, o mRNA carrega a informação para a produção de proteínas, que é realizada fora do núcleo celular. Esta é a fase conhecida como tradução. O mRNA possui duas pontas que não codificam proteína, $5^{\prime}$ UTR e $3^{\prime}$ UTR, e uma região que codifica proteína. O código genético para a produção de proteínas é codificado em forma de códons, onde cada códon é formado por uma tripla de nucleotídeos. Cada tripla codifica um entre os 20 possíveis aminoácidos. Como o número possível de triplas de nucleotídeos é $4^{3}=64$, sabemos que um aminoácido pode ser codificado por mais do que uma tripla de nucleotídeos. Por exemplo, o aminoácido fenilalanina possui duas codificações: UUU e UUC.

A unidade celular responsável pela produção de proteínas a partir do mRNA é o ribossomo. Existem códons especiais para que esta "fábrica" de proteínas possa identificar o ponto inicial do mRNA onde a codificação para aminoácidos deve ter início. O códon de iniciação ou start codon (AUG), correspondente ao aminoácido metiodina, marca o ponto de início do processo de síntese de proteína. O códon de terminação ou stop codon (UAG, UAA ou UGA) indica quando a síntese deve parar. Além do mRNA, o tRNA (RNA transportador) também tem papel fundamental na síntese de proteína. O tRNA possui em sua molécula uma região chamada de anticódon, também formada por três nucleotídeos, correspondente ao códon no mRNA. Por exemplo, o anticódon para a fenilalanina UUU é a tripla AAA. Nesta seção descrevemos o processo de transcrição e tradução de maneira breve, omitindo alguns detalhes. Uma explicação mais completa e detalhada pode ser encontrada em (Alberts et al., 2007).

\subsubsection{DNA microarrays}

A tecnologia de DNA microarrays nos permite medir o nível de transcrição de uma grande quantidade de genes simultaneamente. A utilização dessa tecnologia foi relatada pela primeira vez em (Schena et al., 1995), e um genoma eucarioto completo (Saccharomyces cerevisiae) em um microarray foi publicado pela primeira vez em (Lashkari et al., 1997). A maior parte dos 
dados de expressão gênica utilizados em algoritmos de inferência provém de experimentos de microarrays. Apesar disso, existem outras maneiras de se medir a expressão gênica, como por exemplo, SAGE (serial analysis of gene expression).

O princípio básico por trás do DNA microarray é hibridização entre duas fitas de DNA, através da propriedade da complementaridade entre nucleotídeos. Um gene conhecido é amplificado por reação em cadeia da polimerase ou PCR (polymerase chain reaction). Em seguida, uma certa quantidade de DNA correspondente a este gene é fixado em uma lâmina de vidro (ou outro material, como plástico) em um certo ponto (spot). Milhares de spots são preenchidos e assim, milhares de genes podem ter a sua expressão analisada simultaneamente. Os principais fornecedores comerciais de DNA microarrays são Affymetrix, Illumina, Applied Biosystems, GE Healthcare, Beckman Coulter e Eppendorf Biochip Systems.

Para analisar a expressão gênica em uma célula, os mRNAs são transformados em cDNA (DNA complementar) por uma enzima conhecida como transcriptase reversa. Os cDNAs são marcados com um corante fluorescente (fluoróforo), e se um determinado mRNA estiver presente na célula, seu correspondente cDNA marcado irá se ligar por hibridização à sua cadeia complementar na lâmina. Um processo de lavagem da lâmina remove os cDNAs não hibridizados, e a lâmina passa então por um processo de análise da intensidade do brilho dos spots. Como o fluoróforo brilha ao ser estimulado por luz, é possível medir a intensidade do brilho de cada spot. Esta intensidade indica o nível de expressão do gene correspondente.

No processo acima descrito, usamos apenas um corante. Tal processo corresponde ao que chamamos de single-channel microarray. Outro experimento comum consiste em analisar a expressão gênica em células em condições diferentes, ou seja, analisar duas fontes distintas de mRNA. Neste caso, é utilizado o double-channel microarray, onde o cDNA de uma fonte (teste) é marcada com corante vermelho (Cy5) e a outra fonte (referência) com corante verde (Cy3). Estes cDNAs são misturados e hibridizados em uma mesma lâmina (hibridização competitiva). Assim, spots com brilho na cor vermelho indicam que o gene correspondente está expresso na amostra teste, enquanto que o brilho verde indica a expressão na amostra de referência. No caso em que o gene está expresso em ambas as fontes, o spot tende a apresentar uma fluorescência amarelada. Um esquema mostrando o procedimento realizado em um experimento de microarray (double-channel) é mostrado na Fig. 2.4.

A análise da intensidade dos spots envolve uma fase de processamento da imagem do microarray para extrair o sinal (expressão), analisar sua variabilidade e avaliar a qualidade (Datta e Dougherty, 2007). O objetivo final desta fase é extrair o sinal de cada spot e gerar uma matriz numérica contendo as intensidades dos sinais. Em geral, as linhas desta matriz correspondem aos genes, e as colunas aos experimentos de microarray.

Da maneira como apresentamos, um experimento de microarray poderia medir perfeitamente o nível de expressão dos genes em estudo. Na prática, sabemos que existe uma variação nos dados obtidos, e geralmente assumimos que podem existir diversas fontes de ruído: ruído no preparo da amostra, na rotulação, na hibridização, na extração do brilho fluorescente do spot, entre outros. Algumas abordagens têm sido propostas para quantificar e tratar ruídos em dados de microarray (Chen et al., 2002; Kerr et al., 2000; Lee et al., 2000; Tu et al., 2002).

A hipótese por trás da análise de microarrays é que cada lâmina contém, para cada gene, 


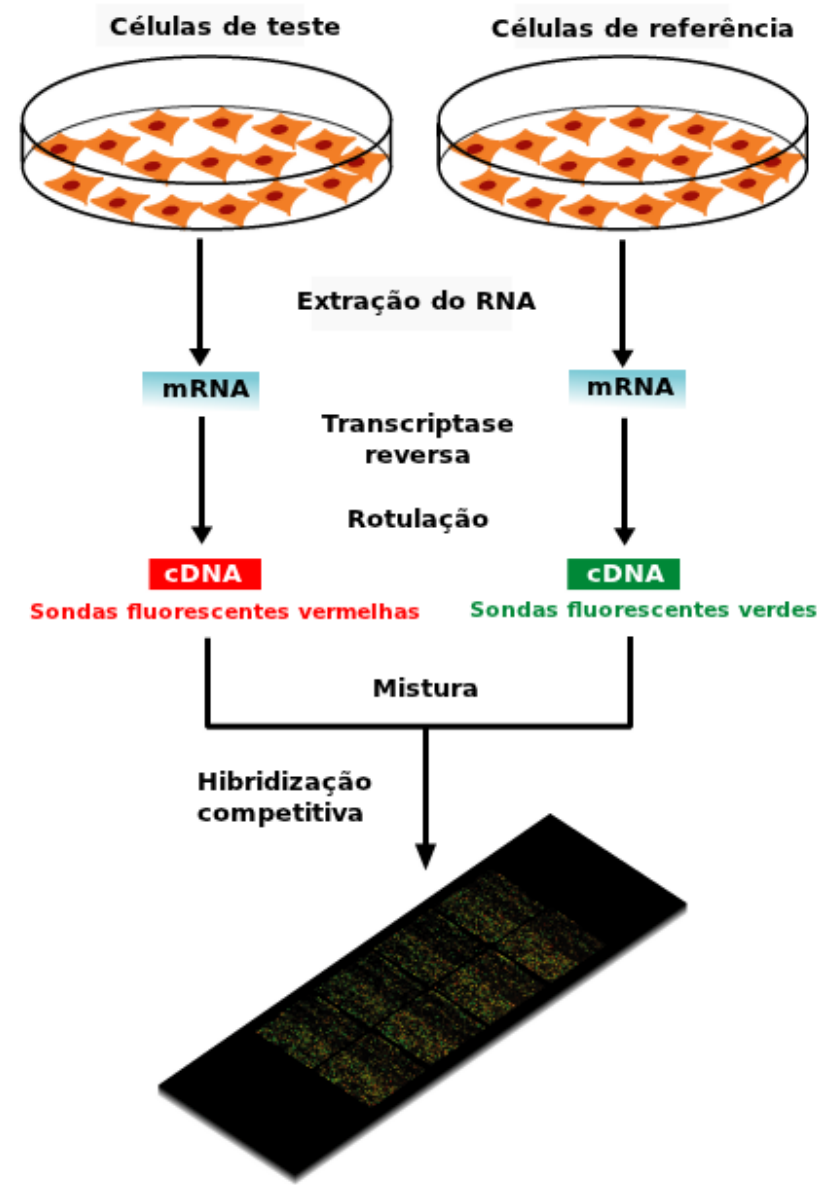

Figura 2.4: Esquema ilustrando os passos de um experimento de microarray (double-channel). Fonte: Wikipedia (2011a).

uma representação do nível de expressão dos genes. Em geral, um estudo envolvendo dados de microarray tende a comparar as expressões gênicas em microarrays distintos. Dessa maneira, os dados precisam passar por um processo de normalização antes de serem comparados. Um dos motivos para que a normalização seja feita é que a quantidade de RNA pode ser diferente. Outro motivo é que pode existir um viés na rotulação fluorescente, por exemplo. Existem algumas abordagens para a normalização de dados de microarrays que podem ser vistos em (Bilban et al., 2002; Quackenbush, 2002; Tseng et al., 2001; Yang et al., 2002).

Os dados de expressão gênica providos por microarrays podem ser basicamente de dois tipos: estacionários ou temporais. Nos dados estacionários, uma amostra (microarray) não possui uma relação de tempo com as outras. Por exemplo, um experimento em que vários microarrays são obtidos, um de cada paciente com câncer. Por outro lado, os dados temporais representam uma análise das expressões ao longo do tempo. Por exemplo, dados obtidos a cada hora do ciclo de vida do parasita Plasmodium falciparum, causador da malária. Neste trabalho, utilizamos apenas dados temporais; estes dados capturam uma visão mais completa do sistema do que dados estacionários (Sima et al., 2009). 


\section{Discretização}

A matriz numérica obtida em um experimento de microarray contém valores no domínio dos números reais, ou seja, os dados são contínuos. Em alguns casos, como neste trabalho, necessitamos trabalhar com dados discretos. Para isso, precisamos discretizar ou quantificar os dados em um certo número de níveis de expressão. O mais comum é discretizar em dois ou três níveis, no máximo. Existem alguns algoritmos para realizar esta tarefa, como por exemplo, EWD (Equal Width Discretization), EFD (Equal Frequency Discretization) (Catlett, 1991; Dougherty et al., 1995), Kmeans (MacQueen, 1967) e CoKmeans discretization (Kmeans aplicado por colunas). Neste trabalho utilizamos um algoritmo chamado BiKmeans (Bidirectional Kmeans discretization) (Li et al., 2010).

Seja $E_{n \times m}$ uma matriz contendo as expressões gênicas de $n$ genes em $m$ amostras. Assim, $E(i,:)$ denota o vetor de expressões do gene $i$ em todas as amostras; $E(:, j)$ denota a expressão de todos os genes na amostra $j$. O algoritmo Kmeans divide $E(i,:)$ em $k$ intervalos de tal forma que valores próximos de expressão do gene $i$ são colocados no mesmo intervalo. Por sua vez, o CoKmeans divide $E(:, j)$ em $k$ intervalos de tal forma que valores próximos na amostra $j$ são colocados no mesmo intervalo.

O algoritmo BiKmeans implementa ambos, Kmeans e CoKmeans, com parâmetro $k+1$, resultando em dois valores discretos para cada valor de expressão gênica. Se o produto dos dois valores é igual ou maior que $e^{2}$, e menor do que $(e+1)^{2}$, o valor discreto final desta expressão é $e$, onde $e$ é um inteiro positivo no intervalo de 1 a $k$. Por exemplo, se uma determinada expressão recebe o valor 3 pelo Kmeans e 2 pelo CoKmeans com parâmetro $k+1=4$, o produto é $2 \times 3=6$, que é maior do que $2^{2}=4$ e menor do que $(2+1)^{2}=9$. Portanto, o valor desta expressão é colocada no segundo intervalo, ou seja, $e=2$. Por exemplo, na Tabela 2.1 temos os possíveis produtos que podemos encontrar entre o valor resultante de Kmeans e CoKmeans. Se o resultado do produto estiver no intervalo [1,3], então o valor da expressão gênica é 1; se estiver no intervalo $[4,6]$ o valor é 2 ; e se estiver no intervalo $[8,16]$ o valor é 3 (Li et al., 2010).

\begin{tabular}{|cc|cccc|}
\hline & & \multicolumn{4}{|c|}{ Kmeans } \\
& & $\mathbf{1}$ & $\mathbf{2}$ & $\mathbf{3}$ & $\mathbf{4}$ \\
\hline \multirow{4}{*}{ CoKmeans } & $\mathbf{1}$ & 1 & 2 & 3 & 4 \\
& $\mathbf{2}$ & 2 & 4 & 6 & 8 \\
& $\mathbf{3}$ & 3 & 6 & 9 & 12 \\
& $\mathbf{4}$ & 4 & 8 & 12 & 16 \\
\hline
\end{tabular}

Tabela 2.1: Os possiveis produtos de Kmeans e CoKmeans são mostrados nesta tabela, para $k+1=4$. Produtos de 1 a 3 são colocados no primeiro intervalo, 4 e 6 no segundo, e de 8 a 16 no terceiro.

Como veremos, neste trabalho utilizamos dados discretizados em dois níveis. Assim, o algoritmo BiKmeans é aplicado com parâmetro $k+1=3$. Sendo assim, as expressões gênicas são separadas em dois intervalos: $[1,3]$ e $[4,9]$. Os valores que caem no primeiro intervalo receberiam o valor $e=1$ pela definição original do algoritmo BiKmeans. No entanto, neste trabalho, o primeiro intervalo corresponde ao valor $e=0$ e consequentemente, o segundo intervalo ao valor $e=1$.

Usando o algoritmo BiKmeans discretizamos os dados de expressão gênica em dois níveis: 0 
ou 1. Quando o valor é 0 dizemos que o gene está inibido, caso contrário o gene está expresso. Na próxima seção apresentaremos modelos de redes de regulação gênica. Entre os modelos apresentados, o modelo de redes Booleanas, utilizado neste trabalho, será apresentado em detalhes, onde voltaremos a discutir esta questão relacionada aos níveis de discretização dos dados. Com os dados de microarray disponíveis, uma questão natural que surge é: como podemos identificar as interações entre os genes observados no fenômeno em questão? Para ajudar a responder esta questão, modelos de redes de regulação gênica e algoritmos para a inferência de tais redes têm sido propostos. Faremos uma revisão sobre estes tópicos nas duas próximas seções.

\subsection{Modelos de redes de regulação gênica}

Os genes, as proteínas, incluindo os fatores de transcrição, e as interações entre estes elementos formam o que chamamos de Redes de Regulação Gênica ${ }^{1}$, ou GRN (gene regulatory networks). Uma GRN é tipicamente representada por um diagrama onde nós representam os genes/proteínas/complexos proteicos; arestas entre pares de genes indicam que existe uma interação entre estes genes, ou seja, o produto de um gene afeta o produto do outro. Estas arestas podem ser direcionadas, indicando ativação ou inibição, por exemplo. Sendo assim, as arestas representam as dependências entre os genes, e ciclos formados por uma sequência de arestas representam feedback loops. A estrutura de uma GRN é uma abstração da dinâmica química do sistema, ilustrada na Fig. 2.5. Na parte superior da figura, temos três níveis: genoma, transcriptoma e proteoma. Existe uma comunicação entre estes níveis. Por exemplo, o gene A atua como fator de transcrição do gene B. Esta dinâmica é abstraída no nível de GRN, na parte inferior da figura.
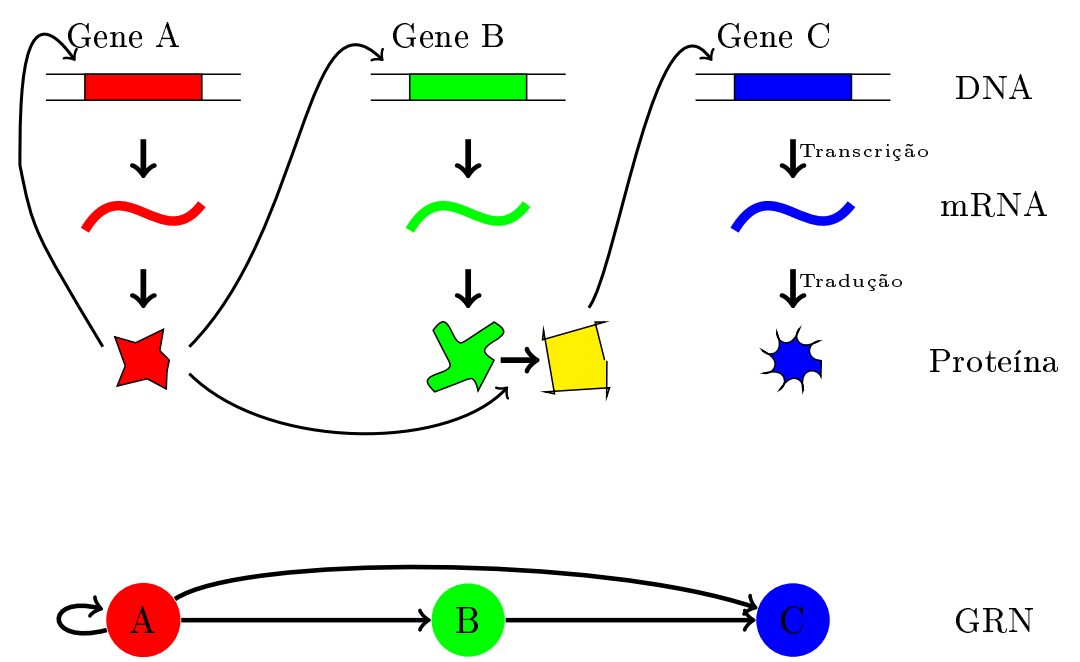

Figura 2.5: Visão esquemática de uma rede de regulação gênica. Figura adaptada de (Hecker et al., 2009).

Modelos matemáticos e computacionais de redes de regulação gênica têm sido desenvolvidos para auxiliar o estudo das interações entre genes/proteínas de sistemas biológicos. Existem modelos estáticos ou dinâmicos, contínuos ou discretos, lineares ou não lineares, determinísticos ou estocásticos (Hache et al., 2009). Nesta seção iremos apresentar brevemente alguns modelos

\footnotetext{
${ }^{1}$ Alguns autores utilizam a expressão Redes de Regulação Genética.
} 
existentes. Como foi mencionado no início deste capítulo, estaremos focando nossa atenção em modelos Booleanos, apresentados na Seção 2.3.

\subsubsection{Redes de relevância}

Redes de relevância ou redes de associação foram propostas por Butte e Kohane (2000) e são baseadas em um esquema de pontuação entre pares de genes. A pontuação é baseada em medidas de similaridade e geralmente utiliza-se a correlação de Pearson, que assume uma dependência linear entre os genes, ou informação mútua que é utilizada no algoritmo ARACNE (Margolin et al., 2006), como veremos mais adiante na próxima seção. Devido ao fato desta rede medir apenas similaridade, elas não podem atribuir direções nas conexões entre os genes (Gardner e Faith, 2005).

\subsubsection{Modelos gráficos Gaussianos}

Modelos gráficos Gaussianos, ou GGM (Graphical Gaussian Models), são modelos gráficos probabilísticos não direcionados que permitem a identificação de relações de independência condicional entre os nós, dentro da suposição de uma distribuição Gaussiana multivariada dos dados (Werhli et al., 2006). GGMs se comportam de maneira similar às redes Bayesianas (Hache et al., 2009). Na próxima seção iremos apresentar brevemente como GGMs podem ser inferidos.

\subsubsection{Equações diferenciais ordinárias}

Um dos modelos contínuos mais populares é o modelo baseado em equações diferenciais ordinárias (EDO). A ideia de utilizar EDO para modelar redes regulatórias foi sugerida décadas atrás (Goodwin, 1963). Muitos modelos têm sido propostos utilizando EDO, alguns lineares e outros não lineares. Em geral, a mudança do nível de expressão de um gene em um certo tempo (contínuo ou discreto) é caracterizado por uma função que leva em consideração a influência regulatória (ativação ou inibição) de outros genes (Lee e Tzou, 2009). Esta função pode ser descrita como:

$$
\frac{d x_{i}}{d t}=f_{i}\left(x_{1}, x_{2}, \ldots, x_{n}, p, u\right),
$$

onde $x_{i}(1 \leq i \leq n)$ é o nível de expressão do gene $i$ no tempo $t, n$ é o número de genes, $p$ é um conjunto de parâmetros do sistema e $u$ é uma perturbação externa. A função $f_{i}$ pode ser linear ou não linear, descrevendo a dinâmica do sistema. Evidentemente, processos regulatórios são caracterizados por uma dinâmica complexa não linear. No entanto, muitas abordagens de inferência de GRN baseadas em EDO consideram modelos lineares ou são limitadas a tipos de funções não lineares muito específicas (DeJong, 2002).

Um modelo baseado em EDO bastante utilizado é o S-system (Savageau, 1969). Neste modelo, 
a taxa de variação da expressão gênica é expressa por:

$$
\frac{d x_{i}}{d t}=\alpha_{i} \prod_{j=1}^{n} x_{j}^{g_{i, j}}-\beta_{i} \prod_{j=1}^{n} x_{j}^{h_{i, j}}
$$

onde $\alpha_{i}$ e $\beta_{i}$ são parâmetros constantes não negativos que indicam a direção do fluxo de massa. Os números reais $g_{i, j}$ e $h_{i, j}$ são expoentes de ordem cinética que refletem a intensidade da interação do gene $x_{j}$ para o gene $x_{i}$ (Lee e Tzou, 2009). Modelos não lineares, como o S-system, que consistem de muitos parâmetros exigem um grande número de experimentos para se adequarem aos dados (Vilela et al., 2008).

Abordagens utilizando equações diferenciais ordinárias fornecem uma informação detalhada sobre a dinâmica da rede, mas necessitam de dados de alta qualidade e, portanto, são apropriadas para poucos sistemas (Karlebach e Shamir, 2008). Podemos citar alguns exemplos de modelagem de GRN utilizando EDO. Li et al. utilizaram EDO para validar o modelo deles para o ciclo celular em Caulobacter crescentus (Li et al., 2007). Chen et al. usaram a mesma abordagem para modelar o ciclo celular em leveduras (Chen et al., 2004). Outro exemplo inclui a modelagem do sistema circadiano em Arabidopsis thaliana (Locke et al., 2005). Maiores detalhes a respeito de EDO em modelagem de GNR podem ser vistos em (Szallasi et al., 2006).

\subsubsection{Redes neurais}

Uma rede neural (no contexto de GRN) pode ser considerada como um modelo de regulação onde cada nó da rede está associado a um gene em particular. O valor do nó corresponde ao valor da expressão do gene. Uma aresta direcionada entre os nós representa uma interação com uma certa "força" indicada por um peso na aresta. A dinâmica de uma rede neural (considerando tempo discreto) formada por $n$ nós é descrita por um sistema de regras de atualização, no qual para cada nó $x_{i}$ :

$$
x_{i}(t+\Delta t)=x_{i}(t)+\Delta t\left[a_{i} S\left(\sum_{j} w_{i j} x_{j}(t)+b_{i}\right)-d_{i} x_{i}(t)\right],
$$

$\forall i \leq n$ (Hache et al., 2009). Os parâmetros do modelo são os pesos $w_{i j}, i, j=1, \ldots, n$, representando a influência do nó $j$ sobre o nó $i$; força de ativação $a_{i}, i=1, \ldots, n$; viés (bias) $b_{i}$, $i=1, \ldots, n$; e taxa de degradação $d_{i}, i=1, \ldots, n$. A função sigmoide $S(x)=\left(1+e^{-x}\right)^{-1}$ realiza a saturação da força de regulação.

Um dos tipos de redes neurais mais utilizados em modelagem de GRN é a rede neural recorrente, ou RNN (recurrent neural network) (Lee e Tzou, 2009). Em uma RNN completamente recorrente, cada nó tem uma aresta apontada para todos os outros nós, inclusive ele mesmo. Dada a rede neural, a tarefa seguinte é ajustar os parâmetros do modelo de acordo com uma estratégia de aprendizagem, como o Backpropagation through time (BPTT) (Werbos, 1990). No entanto, devido à complexidade computacional, esta abordagem pode ser aplicada apenas em sistemas muito pequenos (Lee e Tzou, 2009). 


\subsubsection{Redes Bayesianas}

Outro modelo bastante popular é o modelo de redes Bayesianas (Friedman et al., 2000). Uma rede Bayesiana é um grafo acíclico direcionado (DAG - directed acyclic graph) que estabelece explicitamente as relações probabilísticas entre os nós da rede (Lee e Tzou, 2009). Sejam $X_{1}, X_{2}, \ldots, X_{n}$ as variáveis aleatórias representando os nós (genes) do grafo. Uma rede Bayesiana é definida por um par $B=(G, \Theta)$, onde $G$ é o DAG; e $\Theta$ define um conjunto de distribuições de probabilidade condicional induzidas pela estrutura de $G$, para cada variável. Para cada nó $X_{i}$, $i=1, \ldots, n$, denotamos o conjunto de nós que são pais de $X_{i}$ por $\operatorname{Pa}\left(X_{i}\right)$. Sendo assim, a rede Bayesiana especifica uma distribuição de probabilidade conjunta dada por:

$$
P\left(X_{1}, \ldots, X_{n}\right)=\prod_{i=1}^{n} P\left(X_{i} \mid \operatorname{Pa}\left(X_{i}\right)\right) .
$$

Redes Bayesianas podem ser utilizadas considerando níveis de expressão gênica contínua ou discreta. No entanto, no caso contínuo as redes Bayesianas são tipicamente difíceis de serem inferidas a partir de dados experimentais (Hecker et al., 2009). Além disso, como as redes Bayesianas são representadas graficamente por um grafo acíclico, elas não podem ser usadas para modelar redes que contenham feedback loops.

Para contornar este problema, foi proposto o modelo de redes Bayesianas dinâmicas, ou DBN (dynamic Bayesian networks). A DBN é uma extensão do modelo de redes Bayesianas que leva em consideração o fator tempo. Em uma DBN temos $\mathbf{X}[t]=\left\{X_{1}[t], X_{2}[t], \ldots, X_{n}[t]\right\}$, onde $X_{i}[t], i=$ $1, \ldots, n$, indica o valor da variável aleatória $X_{i}$ no instante $t$. Uma suposição Markoviana é levada em consideração, ou seja, $P(\mathbf{X}[t+1] \mid \mathbf{X}[0], \ldots, \mathbf{X}[t])=P(\mathbf{X}[t+1] \mid \mathbf{X}[t])$ (Friedman et al., 1999). Também é assumido que as transições são independentes do tempo $t$, ou seja, a probabilidade de transição $P(\mathbf{X}[t+1] \mid \mathbf{X}[t])$ é independente de $t$.

Uma DBN que representa a distribuição de probabilidade conjunta sobre todas as possíveis séries temporais das variáveis em $\mathbf{X}$ consiste de duas partes: (1) uma rede Bayesiana inicial $B_{0}=\left(G_{0}, \Theta_{0}\right)$ que define uma distribuição conjunta das variáveis em $\mathbf{X}[0]$; e (2) uma rede Bayesiana de transição $B_{1}=\left(G_{1}, \Theta_{1}\right)$ que especifica as probabilidades de transição $P(\mathbf{X}[t+1] \mid \mathbf{X}[t])$, para todo $t$. Na Figura 2.6 temos um exemplo simples ilustrando uma rede Bayesiana dinâmica com três nós. Na rede $B_{1}$ (mas não em $B_{0}$ ), as variáveis em $\mathbf{X}[0]$ não possuem pais. Sendo assim, uma DBN definida por um par $\left(B_{0}, B_{1}\right)$ corresponde a uma rede sobre as variáveis $\mathbf{X}[0], \ldots, \mathbf{X}[\infty]$ (Friedman et al., 1999). Na prática, apenas intervalos finitos $0, \ldots, T$ são analisados. Dado o modelo de DBN, a distribuição conjunta sobre $\mathbf{X}[0], \ldots, \mathbf{X}[T]$ é

$$
P(\mathbf{x}[0], \ldots, \mathbf{x}[T])=P_{B_{0}}(\mathbf{x}[0]) \prod_{t=0}^{T-1} P_{B_{1}}(\mathbf{x}[t+1] \mid \mathbf{x}[t]),
$$

onde $P_{B_{1}}(\mathbf{x}[t+1] \mid \mathbf{x}[t])$ é obtido através da rede Bayesiana de transição $B_{1}$.

\subsubsection{Redes genéticas probabilísticas}

Uma modelo discreto e estocástico conhecido como redes genéticas probabilísticas (PGN - probabilistic genetic networks) foi introduzido por (Barrera et al., 2004). Uma PGN é uma família 


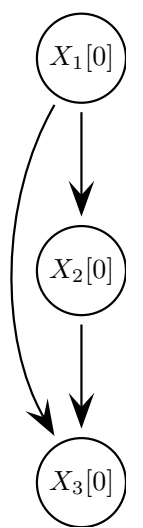

(a) $B_{0}$

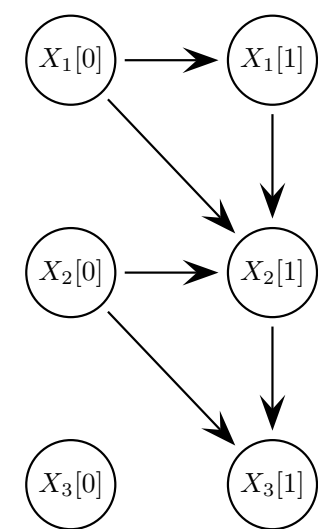

(b) $B_{1}$

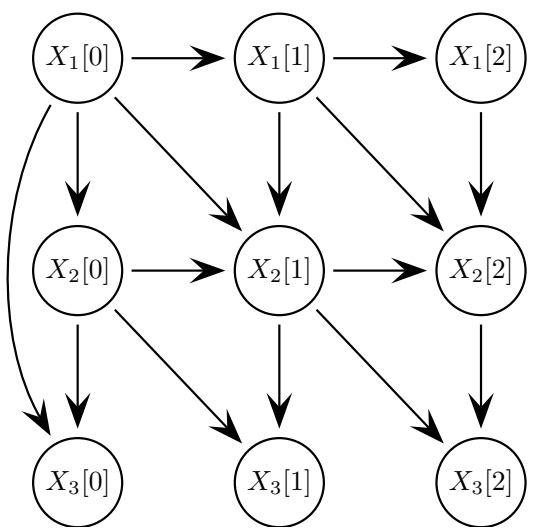

(c) Correspondente rede Bayesiana dinâmica

Figura 2.6: Um exemplo simples de redes Bayesianas dinâmicas retirado de (Friedman et al., 1999). Em (a) temos a rede Bayesiana inicial. Em (b) a rede Bayesiana de transição. Em (c) temos a rede Bayesiana dinâmica formada por $B_{0}$ e $B_{1}$.

particular de cadeias de Markov com algumas propriedades adicionais inspiradas em fenômenos biológicos. Neste modelo, cada gene ou proteína é representado por uma variável que pode assumir um valor em $R$, onde $R=\{0,1\}$ em sistemas binários, $R=\{-1,0,1\}$ em sistemas ternários. Um estado é um vetor composto por todas as variáveis. A função de transição $\phi$, para uma rede de $N$ variáveis e memória $m$, é uma função de $R^{m N}$ para $R^{N}$. Assim, a função $\phi$ mapeia os $m$ estados anteriores, $x(t-1), x(t-2), \ldots, x(t-m)$, em um estado $x(t)$, onde $x(t)=\left[x_{1}(t), x_{2}(t), \ldots, x_{N}(t)\right]^{T} \in R^{N}$.

Na PGN a função de transição $\phi$ é uma função estocástica, ou seja, para cada sequência de estados $x(t-1), x(t-2), \ldots, x(t-m)$, o próximo estado $x(t)$ é uma configuração de um vetor aleatório. Assim, a PNG é uma cadeia de Markov de ordem $m$ (pois depende dos $m$ instantes de tempo anteriores) caracterizada por uma matriz de transição de estados, onde os estados possuem dimensão $m \times N$. Entre as características da PGN podemos citar:

- Possui uma distribuição de probabilidade estacionária;

- Todos os estados são alcançáveis;

- A transição de uma variável é condicionalmente independente da transição de outras variáveis;

- Existe uma trajetória (sequência de estados) que possui uma alta probabilidade de ocorrer, comparada com outras trajetórias.

Este modelo foi aplicado em um estudo de redes gênicas da malária (Barrera et al., 2004, 2007). Para uma descrição mais detalhada da PGN veja (Trepode et al., 2007).

Nesta seção apresentamos brevemente alguns modelos mais populares utilizados em modelagem de redes de regulação gênica. Cada modelo possui suas vantagens e desvantagens. Resumindo, 
modelos contínuos, não lineares, são mais "finos" no sentido de que representam os organismos de maneira mais fiel à realidade. No entanto, esta representação fina tem um preço quando precisamos inferir o modelo, pois necessitamos de uma grande quantidade de dados. O oposto ocorre com modelos discretos, como o modelo de redes Booleanas que apresentaremos na próxima seção. Modelos discretos representam um nível menor de detalhes e são menos realísticos, com a vantagem de que uma quantidade menor de dados é necessária para a sua inferência. O modelo a ser utilizado depende da quantidade de dados disponível e dos objetivos da modelagem e da análise. Segundo o princípio da navalha de Occam (Occam's razor), o modelo não deve ser mais complexo do que o necessário para explicar os dados. Se dois modelos geram predições que condizem com os mesmos dados, então o modelo mais simples é preferível, pois ele pode ser melhor entendido (Karlebach e Shamir, 2008). Na próxima seção, iremos apresentar com mais detalhes os modelos Booleanos, bastante conhecidos e que são utilizados em nosso trabalho. Mais adiante, na Seção 2.4 iremos apresentar brevemente algumas técnicas de inferência de GRNs baseadas em alguns dos modelos aqui apresentados.

\subsection{Modelos Booleanos}

Nesta seção iremos apresentar um modelo discreto conhecido como redes Booleanas, ou simplesmente BN (Boolean networks). As redes Booleanas foram introduzidas na Biologia por Kauffman (Kauffman, 1969). Antes de apresentar uma definição formal de BNs vale a pena levantar alguns pontos que nos levam a utilizar este modelo. Os modelos matemáticos são representações formais simplificadas da realidade. Cada modelo possui suas características e, portanto, podem nos ajudar a responder diferentes perguntas. De fato, a importância de utilizar modelos é que podemos adquirir novos conhecimentos a respeito de um fenômeno. Apesar de sabermos que fenômenos biológicos se manifestam de maneira contínua, é muito comum descrevê-los em uma maneira lógica binária, tal como "ligado" e "desligado", "ativo" e "inativo", e "induzido" e "não induzido" (Shmulevich et al., 2002b). Sendo assim, podemos questionar se podemos extrair alguma informação quando discretizamos os dados de expressão gênica em dois níveis (0 e 1). (Shmulevich e Zhang, 2002) mostraram que utilizando dados binários de cDNA microarrays foi possível mostrar uma clara separação entre diferentes tipos de gliomas, assim como entre diferente tipos de sarcomas. Isto indica que mesmo quando passamos do domínio contínuo para o domínio discreto ainda podemos extrair alguma informação biológica dos dados.

Uma vantagem em utilizar modelos discretos é que eles necessitam de uma quantidade menor de dados para serem inferidos. No caso de dados de expressão gênica, sabemos que em geral temos uma pequena quantidade de amostras disponíveis e uma grande quantidade de genes a serem analisados. Sendo assim, acreditamos que o modelo de redes Booleanas pode nos auxiliar no processo de inferência de GRNs. O modelo Booleano é o modelo discreto relativamente mais simples, porém várias das definições e algoritmos são aplicados a qualquer nível de discretização. 


\subsubsection{Redes Booleanas}

Uma rede Booleana $G(V, F)$ é formada por um conjunto de nós (ou genes, no caso de GRNs) $V=\left\{x_{1}, x_{2}, \ldots, x_{n}\right\}$ e um conjunto de funções Booleanas $F=\left\{f_{1}, f_{2}, \ldots, f_{n}\right\}$. Cada gene $x_{i}$, $i=1, \ldots, n$, pode assumir apenas dois valores: 0 ou 1 . Quando $x_{i}=0$, dizemos que o gene está inibido ou "desligado"; caso contrário, $x_{i}$ está ativo ou "ligado". O valor do gene $x_{i}$ no tempo $t+1$ é determinado por $k_{i}$ genes, $x_{j_{1}(i)}, x_{j_{2}(i)}, \ldots, x_{j_{k_{i}(i)}}$, no tempo $t$ através de uma função Booleana $f_{i}:\{0,1\}^{k_{i}} \rightarrow\{0,1\}$. O mapeamento injetor $j_{k}:\{1, \ldots, n\} \rightarrow\{1, \ldots, n\}, k=1, \ldots, k_{i}$ determina a dependência do gene $x_{i}$ (Shmulevich et al., 2002b). Assim,

$$
x_{i}(t+1)=f_{i}\left(x_{j_{1}(i)}(t), x_{j_{2}(i)}(t), \ldots, x_{j_{k_{i}(i)}}(t)\right) .
$$

Nós assumimos que todos os genes são atualizados de maneira síncrona pelas funções em $F$. Esta sincronia artificial facilita em termos computacionais enquanto preserva as propriedades qualitativas da dinâmica global da rede (Huang, 1999; Kauffman, 1993). A conectividade máxima de uma BN é definida por $K=\max _{i}\left\{k_{i}\right\}$.

Um estado da BN no tempo $t$ é um vetor binário $\mathbf{x}(t)=\left(x_{1}(t), x_{2}(t), \ldots, x_{n}(t)\right)$. Sendo assim, existem $2^{n}$ estados possíveis, $\mathbf{x}_{0}, \mathbf{x}_{1}, \ldots, \mathbf{x}_{2^{n}-1}$. Dado um estado no tempo $t$, a aplicação das funções Booleanas de maneira síncrona leva a rede para o próximo estado no tempo $t+1$ de maneira determinística. Podemos representar estas transições graficamente através de um diagrama de transiçâo de estados. Este diagrama é um grafo onde cada vértice representa um estado da rede; uma aresta direcionada de $\mathbf{x}_{i}$ para $\mathbf{x}_{j}$ indica que as funções em $F$ resultam na transição $\mathbf{x}_{i} \rightarrow \mathbf{x}_{j}$.

Considere um exemplo, retirado de (Shmulevich et al., 2002b), de uma BN contendo cinco genes $\left\{x_{1}, \ldots, x_{5}\right\}$. As funções Booleanas são dadas pelas tabelas-verdade (Tabela 2.2). Neste exemplo, a conectividade máxima é $K=3$, apesar de que algumas variáveis de entrada podem ser duplicadas, reduzindo a conectividade. A função $f_{4}$, por exemplo, é a tabela-verdade da função maioria. Como podemos ver, uma vez que $j_{1}(4)=3$ e $j_{2}(4)=j_{3}(4)=4, f_{4}\left(x_{3}, x_{4}, x_{4}\right)=x_{4}$, que é uma função de apenas uma variável essencial. A maioria entre $x_{3}, x_{4}$ e $x_{4}$ é sempre $x_{4}$, não importa o valor de $x_{3}$.

\begin{tabular}{c||ccccc}
$x_{j_{1}(i)} x_{j_{2}(i)} x_{j_{3}(i)}$ & $f_{1}$ & $f_{2}$ & $f_{3}$ & $f_{4}$ & $f_{5}$ \\
\hline \hline 000 & 0 & 0 & 0 & 0 & 0 \\
001 & 1 & 1 & 1 & 0 & 0 \\
010 & 1 & 1 & 1 & 0 & 0 \\
011 & 1 & 0 & 0 & 1 & 0 \\
100 & 0 & 0 & 1 & 0 & 0 \\
101 & 1 & 1 & 1 & 1 & 0 \\
110 & 1 & 1 & 0 & 1 & 0 \\
111 & 1 & 1 & 1 & 1 & 1 \\
\hline \hline$j_{1}$ & 5 & 3 & 3 & 3 & 5 \\
$j_{2}$ & 2 & 5 & 1 & 4 & 4 \\
$j_{3}$ & 4 & 4 & 5 & 4 & 1
\end{tabular}

Tabela 2.2: Os indices $j_{1}, j_{2}$ e $j_{3}$ indicam as conexões de entrada para cada gene. Tabela adaptada de (Shmulevich et al., 2002b). 
O grafo que representa o diagrama de transição de estados da BN dado pela Tabela 2.2 é apresentado na Figura 2.7. É fácil ver que devido ao número finito de estados e ao comportamento determinístico, certos estados serão revisitados de maneira cíclica, dependendo do estado inicial. Tais estados são chamados de atratores; os estados que levam a um atrator são estados transientes. A bacia de atração de um atrator é formado pelos estados que compõem o atrator juntamente com os estados transientes que levam a este atrator. Por exemplo, na Fig. 2.7, o estado (00000) é um atrator e juntamente com os outros sete estados que levam a ele temos a bacia de atração deste atrator. Atratores que possuem um único estado são chamados de singletons ou pontos fixos. O atrator (00000) é um singleton, porém o atrator formado pelos estados (11110) e (11010) não é um atrator singleton.

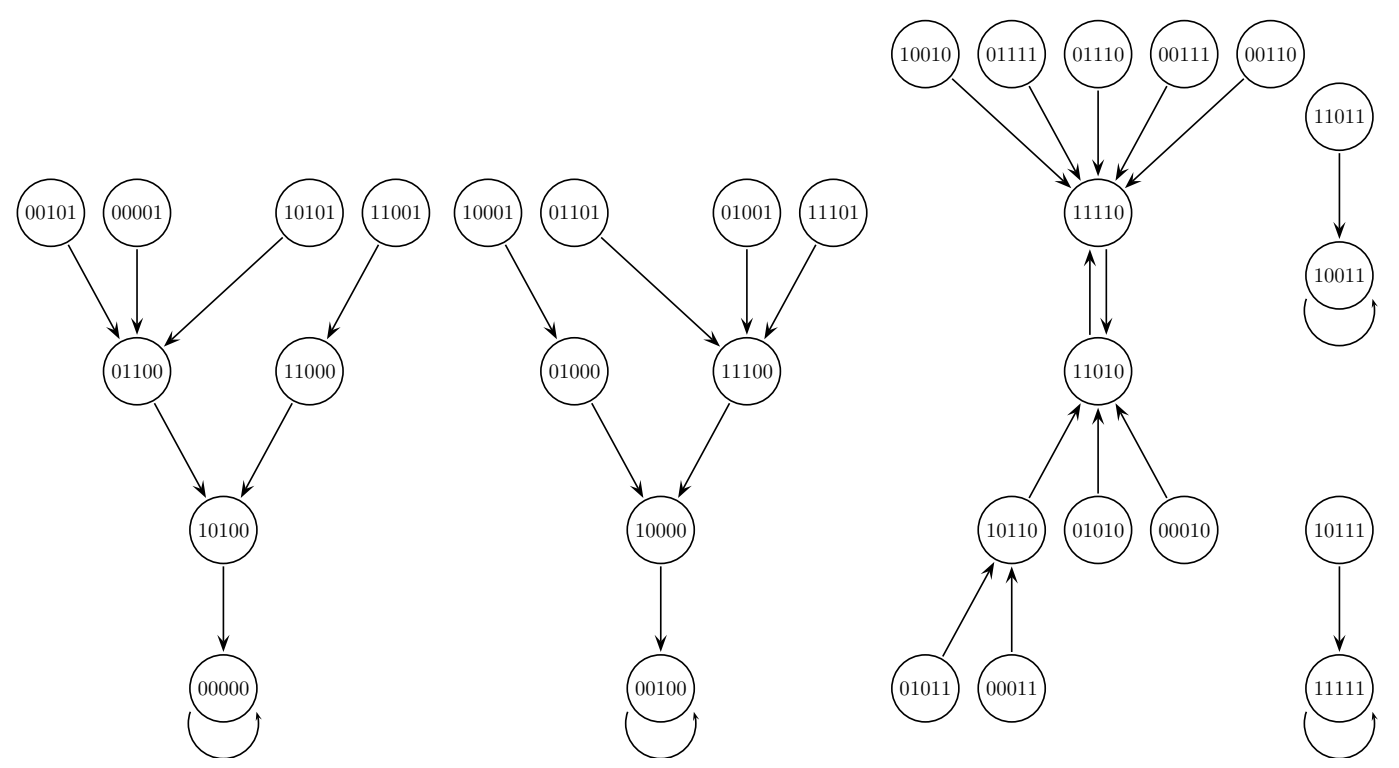

Figura 2.7: Diagrama de transição de estados da BN definida na Tabela 2.2. Figura adaptada de (Shmulevich et al., 2002b).

Os atratores desempenham um papel importante pois representam o comportamento assintótico do sistema. Como veremos no próximo capítulo, em alguns casos supomos que os dados de expressão gênica representam o sistema biológico em equilíbrio, que no caso de redes Booleanas é representado pelos atratores. A intuição de Kauffman era de que os atratores das redes Booleanas deveriam corresponder a tipos de células (Kauffman, 1969, 1993). Huang apresentou o conceito de "cancer attractors" em que células cancerosas estão presas em atratores "anormais" (Huang e Ingber, 2007; Huang et al., 2009).

\subsubsection{Redes Booleanas com limiar}

Na definição de redes Booleanas, o conjunto de funções $F$ pode conter qualquer função $f_{i}$, $i=1, \ldots, n$, tal que $f_{i}:\{0,1\}^{k_{i}} \rightarrow\{0,1\}$ e $1 \leq k_{i} \leq n$. O número total de funções Booleanas possíveis para um gene $x_{i}$ é $2^{2^{k_{i}}}$. Em uma rede Booleana com limiar ou tBN (thresholded Boolean network) não são consideradas todas as funções possíveis; existe uma restrição no espaço de funções. Antes de definir a classe de funções de uma tBN vamos definir uma matriz de regulação 
$A_{n \times n}$ onde

$$
a_{i, j}=\left\{\begin{aligned}
-1, & \text { para uma regulação negativa de } x_{j} \text { para } x_{i} \\
1, & \text { para uma regulação positiva de } x_{j} \text { para } x_{i} \\
0, & \text { caso contrário. }
\end{aligned}\right.
$$

Este modelo permite que os genes possuam uma característica de auto-degradação. Se um gene $x_{i}$ possui tal característica, temos $a_{i, i}=-1$. Dada a matriz $A$, chamamos de entrada ou input do gene $x_{i}$ no tempo $t$ o seguinte somatório:

$$
\mathcal{I}_{i}(t)=\sum_{j=1}^{n} a_{i, j} \cdot x_{j}(t) .
$$

Definimos então o valor do gene $x_{i}$ no tempo $t+1$ da seguinte maneira:

$$
x_{i}(t+1)=\left\{\begin{aligned}
1, & \text { se } \mathcal{I}_{i}(t)>\tau \\
0, & \text { se } \mathcal{I}_{i}(t)<\tau \\
x_{i}(t), & \text { se } \mathcal{I}_{i}(t)=\tau
\end{aligned}\right.
$$

onde $\tau$ é um limiar. Neste trabalho utilizamos $\tau=0$. Como podemos ver, a função Booleana para o gene $x_{i}$, representada pela Equação 2.9, toma como entrada o próprio gene $x_{i}$, pois quando $\mathcal{I}_{i}(t)=\tau$ o valor de $x_{i}$ no tempo $t+1$ não se altera.

Para ilustrar, vamos considerar uma pequena rede contendo apenas quatro genes. Na Fig. 2.8 temos a representação gráfica da interação ou regulação entre os genes. Flechas de um gene $x_{j}$ para um gene $x_{i}$ indicam uma interação positiva e implicam em $a_{i, j}=1$; arestas com uma barra na extremidade indicam uma interação negativa e implicam em $a_{i, j}=-1$; o laço tracejado no gene $x_{2}$ indica que este gene possui a característica de auto-degradação, ou seja, $a_{2,2}=-1$.

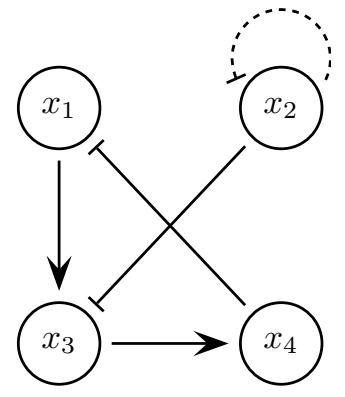

Figura 2.8: Representação gráfica da interação entre os quatro genes.

Dadas as relações de interação na Fig. 2.8, podemos construir diretamente a correspondente matriz de regulação:

$$
A=\begin{gathered}
x_{1} \\
x_{1} \\
x_{2} \\
x_{3} \\
x_{4}
\end{gathered}\left(\begin{array}{cccc}
0 & 0 & 0 & -1 \\
0 & -1 & 0 & 0 \\
1 & -1 & 0 & 0 \\
0 & 0 & 1 & 0
\end{array}\right) .
$$


Aplicando a função Booleana definida pela Equação 2.9 para cada estado possível, podemos construir o diagrama de transição de estados, apresentado na Fig. 2.9.

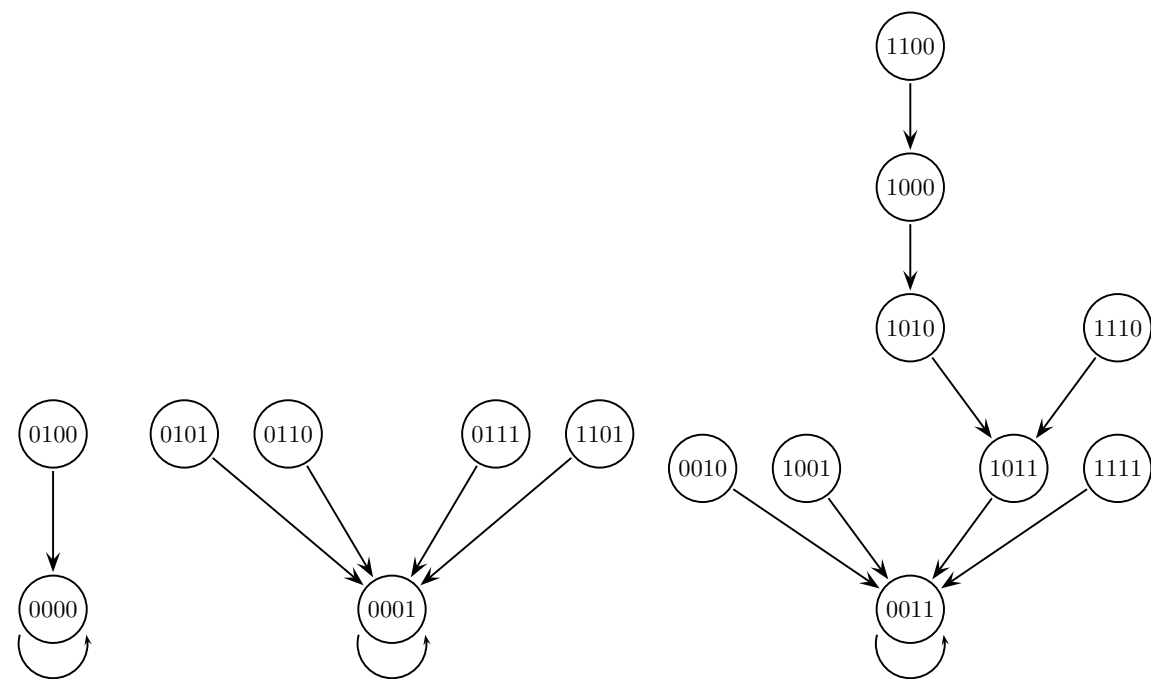

Figura 2.9: Diagrama de transição de estados da tBN definida na Fig. 2.8

Para ver que nem todas as funções Booleanas podem ser representadas seguindo este modelo, considere um caso em que temos três genes $x_{1}, x_{2}$ e $x_{3}$. Seja $f_{3}$ uma função Booleana que define o valor do gene $x_{3}$ no tempo $t+1$ tal que $x_{3}(t+1)=f_{3}\left(x_{1}(t), x_{2}(t), x_{3}(t)\right)$. Pode-se verificar que $f_{3}(0,0,0)=0$ qualquer que seja a matriz $A$ pois o input em $x_{3}$ será nulo. Assim, jamais teremos $f_{3}(0,0,0)=1$. De fato, neste modelo temos $f_{i}(0,0, \ldots, 0)=0$ para qualquer gene $x_{i}$. Outro exemplo é a função XOR (OU exclusivo) na Tabela 2.3. Neste caso, $x_{1}(t+1)=f_{1}\left(x_{1}(t), x_{2}(t)\right)=$ $x_{1}(t) \oplus x_{2}(t)$, onde $\oplus$ representa a operação XOR. Não existe uma configuração da matriz $A$ tal que seja possível representar esta função.

\begin{tabular}{|c|c||c|}
\hline$x_{1}(t)$ & $x_{2}(t)$ & $x_{1}(t+1)$ \\
\hline \hline 0 & 0 & 0 \\
\hline 0 & 1 & 1 \\
\hline 1 & 0 & 1 \\
\hline 1 & 1 & 0 \\
\hline
\end{tabular}

Tabela 2.3: Função XOR para determinar o valor de $x_{1}(t+1)$.

\subsubsection{Redes Booleanas com perturbação}

Até o momento, consideramos redes Booleanas completamente determinísticas. Sendo assim, se olharmos para o diagrama de transição de estados de uma BN, cada estado possui apenas uma única aresta de saída. Sabemos que os organismos não são sistemas fechados, i.e., nos organismos os genes estão sujeitos a estímulos externos como variações de temperatura, mutações, etc. Este fenômeno é modelado através de uma perturbação. Portanto, qualquer gene, dentre os $n$ possíveis, pode ser perturbado com probabilidade $p$, independente dos outros genes. Esta perturbação corresponde a uma troca de valor do gene de 0 para 1, ou vice versa (Shmulevich et al., 2002c).

Suponhamos que, a cada passo, temos um vetor de perturbação aleatório $\gamma \in\{0,1\}^{n}$. Se a 
$i$-ésima posição de $\gamma$ é igual a 1 , então o gene $x_{i}$ tem o seu valor trocado, caso contrário, não. Por simplicidade, assumimos que $\gamma$ é independente e identicamente distribuído (i.i.d.). Assim, iremos supor que $\operatorname{Pr}\left[\gamma_{i}=1\right]=\mathrm{E}\left[\gamma_{i}\right]=p$ para $i=1, \ldots, n$. Portanto,

$$
\operatorname{Pr}[\gamma=(0, \ldots, 0)]=(1-p)^{n}
$$

Seja $\mathbf{x}(t)$ o estado da rede no tempo $t$, então o próximo estado $\mathbf{x}(t+1)$ é dado por:

$$
\mathbf{x}(t+1)= \begin{cases}\mathbf{x}(t) \oplus \gamma, & \text { com probabilidade } 1-(1-p)^{n} \\ \mathbf{f}\left(x_{1}(t), \ldots, x_{n}(t)\right), & \text { com probabilidade }(1-p)^{n}\end{cases}
$$

onde $\oplus$ corresponde à operação $\mathrm{OU}$ exclusivo $(\mathrm{XOR})$ e $\mathbf{f}\left(x_{1}(t), \ldots, x_{n}(t)\right)$ corresponde à aplicação das funções Booleanas em $F$ para cada gene (Shmulevich et al., 2002c).

Uma rede Booleana com perturbação em que $p>0$ pode ser vista como uma cadeia de Markov homogênea $\mathbf{X}$ e espaço de estados $\{0,1\}^{n}$. Para cada par de estados $\mathbf{x}_{i}$ e $\mathbf{x}_{j}, i, j \in\left\{0, \ldots, 2^{n}-1\right\}$, e para qualquer instante $t, \operatorname{Pr}\left[\mathbf{x}_{i} \rightarrow \mathbf{x}_{j}\right]=\operatorname{Pr}\left[\mathbf{X}(t+1)=\mathbf{x}_{j} \mid \mathbf{X}(t)=\mathbf{x}_{i}\right]$ é a probabilidade de transitar do estado $\mathbf{x}_{i}$ para $\mathbf{x}_{j}$. Esta probabilidade é composta pelas probabilidades em 2.12. Sendo assim, se $\operatorname{Pr}^{*}\left[\mathbf{x}_{i} \rightarrow \mathbf{x}_{j}\right]$ é a probabilidade de que uma perturbação mova o sistema do estado $\mathbf{x}_{i}$ para $\mathbf{x}_{j}$, as probabilidades de transição da cadeia de Markov $\mathbf{X}$ é dada por:

$$
\begin{aligned}
& \operatorname{Pr}\left[\mathbf{x}_{i} \rightarrow \mathbf{x}_{j}\right]= \\
= & \mathbf{1}_{\left[\mathbf{f}\left(\mathbf{x}_{i}\right)=\mathbf{x}_{j}\right]} \cdot(1-p)^{n}+\operatorname{Pr}^{*}\left[\mathbf{x}_{i} \rightarrow \mathbf{x}_{j}\right] \cdot\left(1-(1-p)^{n}\right) \\
= & \mathbf{1}_{\left[\mathbf{f}\left(\mathbf{x}_{i}\right)=\mathbf{x}_{j}\right]} \cdot(1-p)^{n}+\left(1-\mathbf{1}_{\left[\mathbf{x}_{i}=\mathbf{x}_{j}\right]}\right) \times \frac{p^{\eta\left(\mathbf{x}_{i}, \mathbf{x}_{j}\right)}(1-p)^{n-\eta\left(\mathbf{x}_{i}, \mathbf{x}_{j}\right)}}{\left(1-(1-p)^{n}\right)}\left(1-(1-p)^{n}\right) \\
= & \mathbf{1}_{\left[\mathbf{f}\left(\mathbf{x}_{i}\right)=\mathbf{x}_{j}\right]} \cdot(1-p)^{n}+\left(1-\mathbf{1}_{\left[\mathbf{x}_{i}=\mathbf{x}_{j}\right]}\right) p^{\eta\left(\mathbf{x}_{i}, \mathbf{x}_{j}\right)} \times(1-p)^{n-\eta\left(\mathbf{x}_{i}, \mathbf{x}_{j}\right)},
\end{aligned}
$$

onde a função indicadora $\mathbf{1}_{[P]}=1$ se a proposição $P$ é verdadeira, e $\mathbf{1}_{[P]}=0$ caso contrário; e a função $\eta\left(\mathbf{x}_{i}, \mathbf{x}_{j}\right)$ é a distância Hamming (número de bits diferentes) entre dois vetores binários $\mathbf{x}_{i}$ e $\mathbf{x}_{j}$ (Brun et al., 2005).

Se calcularmos a matriz de transição de estados $P_{2^{n} \times 2^{n}}$ onde $p_{i j}=\operatorname{Pr}\left[\mathbf{x}_{i} \rightarrow \mathbf{x}_{j}\right]$, temos que $p_{i j}>0, \forall i, j$, se tivermos $p>0$. Desta maneira, os estados da cadeia de Markov são aperiódicos. Além disso, como é possível transitar de qualquer estado para qualquer outro estado (não necessariamente em um passo), a cadeia de Markov é irredutivel. Uma cadeia de Markov aperiódica e irredutível é chamada de cadeia de Markov ergódica, e possui uma única distribuição de probabilidade estacionária П. A distribuição estacionária nos permite analisar o comportamento assintótico do sistema, independentemente do estado inicial.

Como, em geral, consideramos que a probabilidade de perturbação é muito pequena, i.e., $p \approx 0$, a matriz de transição tem uma característica específica. Para cada linha $i$ de $P$, existe uma coluna $j$ tal que $p_{i j} \gg p_{i k}, k \neq j$. Esta probabilidade $p_{i j}$ corresponde justamente ao par de estados $\left(\mathbf{x}_{i}, \mathbf{x}_{j}\right)$ cuja transição $\mathbf{x}_{i} \rightarrow \mathbf{x}_{j}$ ocorreria de maneira determinística se tivéssemos $p=0$. Dizemos que a matriz $P$ é "quase determinística" quando possui esta característica. 


\subsubsection{Redes Booleanas probabilísticas}

As redes Booleanas probabilísticas, ou PBN (probabilistic Boolean networks), foram introduzidas por Shmulevich como modelos de redes de regulação gênica (Shmulevich et al., 2002a,b). A ideia básica das PBNs é permitir que cada gene $x_{i}$ possua mais do que uma única função Booleana de atualização. Assim, para cada gene $x_{i}$ temos um conjunto $F_{i}=\left\{f_{1}^{(i)}, f_{2}^{(i)}, \ldots, f_{l(i)}^{(i)}\right\}$ de $l(i)$ funções Booleanas. Uma instância da PBN é definida por um vetor de funções $\mathbf{f}_{k}=$ $\left(f_{k_{1}}^{(1)}, f_{k_{2}}^{(2)}, \ldots, f_{k_{n}}^{(n)}\right), k=1, \ldots, N$, onde $N=\Pi_{i=1}^{n} l(i)$ é o total de instâncias possíveis. Além disso, $1 \leq k_{i} \leq l(i)$ e $f_{k_{i}}^{(i)} \in F_{i}, i=1, \ldots, n$. Em outras palavras, o vetor de funções $\mathbf{f}_{k}$ : $\{0,1\}^{n} \rightarrow\{0,1\}^{n}$ funciona como um mapeamento representando uma possível instância de uma PBN (Shmulevich et al., 2002a). Sendo assim, dado um estado $\mathbf{x}(t), \mathbf{f}_{k}(\mathbf{x}(t))=\mathbf{x}(t+1)$ é o próximo estado da rede dado pela instância $\mathbf{f}_{k}$. Obviamente, se $l(i)=1, \forall i$, então temos apenas uma BN.

Seja $\mathbf{f}=\left(f^{(1)}, \ldots, f^{(n)}\right)$ um vetor aleatório assumindo valores em $F_{1} \times \cdots \times F_{n}$. Ou seja, $\mathbf{f}$ pode assumir qualquer instância possível da PBN. A probabilidade de que a função $f_{j}^{(i)}, 1 \leq j \leq l(i)$, seja escolhida para o gene $x_{i}$ é igual a

$$
c_{j}^{(i)}=\operatorname{Pr}\left[f^{(i)}=f_{j}^{(i)}\right]=\sum_{k: f_{k_{i}}^{(i)}=f_{j}^{(i)}} \operatorname{Pr}\left[\mathbf{f}=\mathbf{f}_{k}\right] .
$$

Uma vez que $c_{j}^{(i)}$ são probabilidades, temos que

$$
\sum_{j=1}^{l(i)} c_{j}^{(i)}=1
$$

A Fig. 2.10 ilustra a estrutura básica de uma PBN.

A dinâmica de uma PBN é essencialmente a mesma das redes Booleanas, mas a cada passo uma nova instância da PBN é escolhida (pode ser que a própria instância atual seja escolhida). Sendo assim, uma PBN pode ser vista como uma coleção de BNs, $\mathbf{f}_{1}, \mathbf{f}_{2}, \ldots, \mathbf{f}_{N}$. Para calcular a probabilidade de cada $\mathrm{BN}$ ser selecionada vamos primeiramente definir a matriz

$$
D=\left[\begin{array}{ccccc}
1 & 1 & \ldots & 1 & 1 \\
1 & 1 & \ldots & 1 & 2 \\
\vdots & \vdots & \ddots & \vdots & \vdots \\
1 & 1 & \ldots & 1 & l(n) \\
1 & 1 & \ldots & 2 & 1 \\
1 & 1 & \ldots & 2 & 2 \\
\vdots & \vdots & \ddots & \vdots & \vdots \\
1 & 1 & \ldots & 2 & l(n) \\
\vdots & \vdots & \ddots & \vdots & \vdots \\
l(1) & l(2) & \cdots & l(n-1) & l(n)
\end{array}\right]
$$

contendo linhas ordenadas de maneira lexicográfica, cada uma correspondendo a uma possível rede Booleana (Shmulevich et al., 2002a). Assim, a posição $d_{j i}$ especifica que a função Booleana 


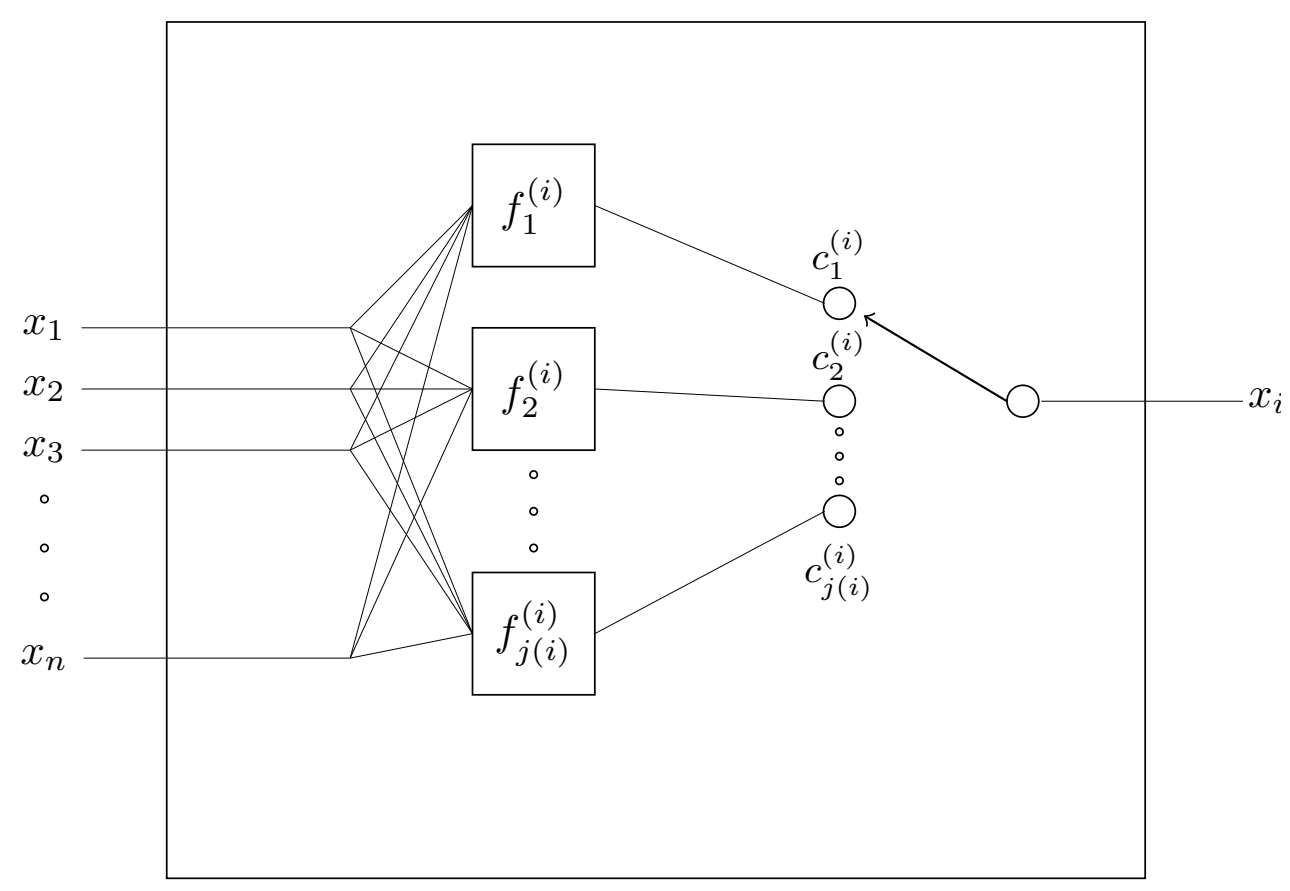

Figura 2.10: Estrutura básica de uma PBN (Shmulevich et al., 2002a).

$f_{j}^{(i)}$ deve ser usada pelo gene $x_{i}$. É fácil ver que $D$ é uma matriz $N \times n$. Usando esta matriz, a probabilidade de que uma $B N \mathbf{f}_{k}$ seja escolhida é dada por

$$
P_{k}=\prod_{i=1}^{n} c_{d_{k i}}^{(i)} .
$$

Cada BN que compõe a PBN pode ser uma BN com perturbação. Brun et al. (2005) apresentaram fórmulas analíticas para calcular a matriz de transição de estados da cadeia de Markov no caso de PBNs com perturbação.

Em um caso mais geral, temos as redes Booleanas probabilisticas sensiveis ao contexto (cPBN - context-sensitive PBN). Em uma cPBN, cada $\mathrm{BN} \mathbf{f}_{1}, \mathbf{f}_{2}, \ldots, \mathbf{f}_{N}$ define um contexto em que o sistema se encontra. A cada passo, a cPBN troca de contexto com uma probabilidade $q$. Se $q \approx 0$ então a cPBN é pouco sensível e permanecerá em um determinado contexto por um certo número de passos. No caso em que $q=1$ temos que a $c$ PBN troca de contexto a cada passo, como nas PBNs. Na próxima seção apresentaremos alguns algoritmos/métodos de inferência de GRNs existentes.

\subsection{Algoritmos para inferência de redes}

Nas Seções 2.2 e 2.3 apresentamos alguns modelos matemáticos que são utilizados para modelar GRNs. Nesta seção, estaremos apresentando brevemente algumas técnicas e métodos de inferência encontradas na literatura. 


\subsubsection{Redes de relevância}

O método de redes de relevância foi proposto em (Butte e Kohane, 2000) e é baseado na correlação entre pares de genes. Assim, a correlação é calculada para todos os pares de genes. Por exemplo, para dados contínuos, a correlação de Pearson pode ser utilizada:

$$
\operatorname{corr}(x, y)=\frac{(1 / m) \sum_{i=1}^{m}\left(x_{i}-\bar{x}\right)\left(y_{i}-\bar{y}\right)}{\sqrt{(1 / m) \sum_{i=1}^{m}\left(x_{i}-\bar{x}\right)^{2}} \sqrt{(1 / m) \sum_{i=1}^{m}\left(y_{i}-\bar{y}\right)^{2}}},
$$

onde $x=\left(x_{1}, \ldots, x_{m}\right)$ e $y=\left(y_{1}, \ldots, y_{m}\right)$ são observações $m$-dimensionais de duas variáveis diferentes com média empírica $\bar{x}$ e $\bar{y}$, respectivamente (Emmert-Streib e Dehmer, 2008). Assim, uma correlação cujo valor exceda um determinado limiar resulta em uma aresta não direcionada entre os genes correspondentes.

Um algoritmo que se tornou bastante popular é o ARACNE (Margolin et al., 2006). Este algoritmo utiliza redes de relevância em conjunto com a informação mútua (IM) que vem da Teoria da Informação. A informação mútua para um par de variáveis aleatórias discretas $X$ e $Y$ pode ser definida como:

$$
I(X, Y)=\sum_{y \in Y} \sum_{x \in X} p(x, y) \cdot \log \frac{p(x, y)}{p(x) \cdot p(y)},
$$

onde $p(x, y)$ é a distribuição conjunta de $X$ e $Y$, e $p(x)$ e $p(y)$ são as probabilidades marginais de $X$ e $Y$, respectivamente. De maneira intuitiva, a IM mede a informação que $X$ e $Y$ compartilham. Além da informação mútua, o algoritmo ARACNE utiliza uma técnica conhecida como Data Processing Inequality, ou DPI, que estabelece que se duas variáveis $X$ e $Y$ interagem apenas através de uma terceira variável $Z(X \rightarrow Z \rightarrow Y$ ou $Y \rightarrow Z \rightarrow X)$, então

$$
I(X, Y) \leq \min \{I(X, Z) ; I(Z, Y)\}
$$

O algoritmo inicia com um grafo onde cada $I\left(X_{i}, X_{j}\right)>I_{0}$ é representada por uma aresta $(i, j)$, para um limiar $I_{0}$. O algoritmo então examina cada tripla de genes em que todas as três IMs são maiores do que $I_{0}$ e remove a aresta com o menor valor. O DPI funciona neste cenário, porém em um cenário divergente, i.e., $X \leftarrow Z \rightarrow Y$ todos os três pares $(X, Y),(X, Z)$ e $(Y, Z)$ apresentam IM positiva, mas não existe uma inequalidade definida entre eles. Um outro método, conhecido como CLR (Faith et al., 2007), calcula uma medida baseada na distribuição dos valores da IM, ao invés de considerar $I(X, Y)$ diretamente. Em (Zhao et al., 2008) foi explorado o conceito de informação mútua condicional definida (para valores discretos) como:

$$
I(X ; Y \mid Z)=\sum_{\mathcal{X}, \mathcal{Y}, \mathcal{Z}}\left[p(x, y \mid z) \cdot \log \frac{p(x, y \mid z)}{p(x \mid z) \cdot p(y \mid z)}\right],
$$

onde $p(x, y \mid z), p(x \mid z)$ e $p(y \mid z)$ são distribuições de probabilidade condicional. Dado o gene intermediário $Z$, os genes $X$ e $Y$ se tornam independentes e, portanto, a informação mútua condicional $I(X ; Y \mid Z)$ tende a zero (Zhao et al., 2008). 


\subsubsection{Modelos gráficos Gaussianos}

Na Seção 2.2 vimos que em GGMs supomos que os dados seguem uma distribuição Gaussiana multivariada $N(\mu, \Sigma)$. A inferência de GGMs é baseada na estimação da matriz de covariância $\Sigma$ desta distribuição. Sejam dois genes $X_{i}$ e $X_{j}$, a força de associação entre eles é medida pelo coeficiente de correlação parcial $\rho_{i j}$. A partir da teoria das distribuições normais, é conhecido que os coeficientes $\rho_{i j}$ podem ser calculados a partir da inversa $\Omega=\Sigma^{-1}$ da matriz de covariância através da seguinte relação (Emmert-Streib e Dehmer, 2008):

$$
\rho_{i j}=\frac{-\omega_{i j}}{\sqrt{\omega_{i i} \omega_{j j}}}
$$

onde $\omega_{i j}$ são os elementos da matriz $\Omega$.

Para inferir um GGM, aplica-se o seguinte procedimento. A partir dos dados, uma matriz de covariância empírica é estimada e invertida. A seguir, as correlações parciais $\rho_{i j}$ são calculadas a partir da Equação 2.21. Arestas $(i, j)$ correspondentes a valores baixos de $\rho_{i j}$ são descartadas. O passo crítico deste procedimento é a estimação da matriz de covariância e sua inversa (Werhli et al., 2006).

\subsubsection{Redes neurais}

Como foi mencionado na Seção 2.2, a estratégia de aprendizagem dos parâmetros de uma rede neural é o algoritmo Backpropagation through time (BPTT) (Werbos, 1990). O BPTT é um algoritmo iterativo de aprendizagem de parâmetros baseado em gradiente que minimiza a função erro

$$
E(\mathbf{x}, \hat{\mathbf{x}})=\frac{1}{2} \sum_{t} \sum_{i}\left[x_{i}(t)-\hat{x}_{i}(t)\right]^{2}
$$

através da variação dos parâmetros do modelo (W, a, b, d) (ver Seção 2.2) a cada passo. Na Equação 2.22, $\mathbf{x}$ é o vetor dos valores calculados, e $\hat{\mathbf{x}}$ são os dados de expressão gênica (em tempo discreto) (Hache et al., 2009). A matriz $\mathbf{W}$ de força de regulação possui valores reais, que são discretizados para obter uma matriz binária ou ternária, representando assim a topologia da rede.

\subsubsection{Equações diferenciais ordinárias}

O processo de inferência de GRNs modeladas por equações diferenciais ordinárias consiste em encontrar os parâmetros do modelo que fazem com que o modelo explique os dados de expressão gênica. A função em 2.1 pode ser linear ou não linear. Uma função muito encontrada na literatura para modelar a expressão de um gene alvo através de outro gene é a curva de Hill (Hill curve) (DeJong, 2002):

$$
h^{+}\left(x_{j}, \theta_{j}, m\right)=\frac{x_{j}^{m}}{x_{j}^{m}+\theta_{j}^{m}},
$$


onde $\theta_{j}>0$ é um limiar para a influência regulatória de $x_{j}$ em um dado gene alvo e $m>0$ é um parâmetro de declividade. Esta função se concentra no intervalo $[0,1]$ e cresce quando $x_{j} \rightarrow \infty$.

Quando a função $f_{i}$ é não linear, é difícil encontrar soluções analíticas para 2.1. Além disso, o número de amostras, que em geral é pequeno, dificulta a identificação das interações não lineares (Hecker et al., 2009). No caso de EDO lineares, algumas abordagens utilizam técnicas da Álgebra Linear para solucionar as equações. Por exemplo, Di Bernardo et al. (2004) utilizaram técnicas de regressão linear para inferir o modelo a partir de dados de expressão gênica. Outras abordagens podem ser encontradas em (Chang et al., 2008) e (Fuente et al., 2004).

\subsubsection{Redes Bayesianas}

Existe uma grande quantidade de algoritmos de inferência baseados em redes Bayesianas. Este modelo pode ser inferido a partir de dados discretos ou contínuos, porém, este último torna o problema mais difícil devido ao aumento na complexidade computacional. Dados estacionários podem ser utilizados para inferir redes Bayesianas, e dados temporais para redes Bayesianas dinâmicas. Métodos para aprendizagem de redes Bayesianas são cobertos com mais detalhes em (Needham et al., 2007). Resumindo, existem três partes essenciais no processo de inferência de redes Bayesianas (Hecker et al., 2009):

- Seleção do modelo. Defina um grafo acíclico direcionado (DAG) G como candidato para o grafo de conexões;

- Ajuste de parâmetros. Dado o grafo e os dados experimentais, encontre a melhor probabilidade condicional para cada nó $(\Theta)$;

- Avaliação do ajuste. Avalie cada modelo $B=(G, \Theta)$ atribuindo uma pontuação. Quanto maior a pontuação, melhor o ajuste do modelo aos dados. O modelo com a maior pontuação representa a GRN inferida.

Mesmo para um número pequeno de variáveis pode existir uma grande quantidade de grafos $G$ possíveis, dificultando a inferência e a aprendizagem dos parâmetros $\Theta$. Algumas abordagens como Monte Carlo Markov Chain (MCMC) e busca gulosa podem ser aplicadas para tratar este problema (Needham et al., 2007). Na parte de ajuste de parâmetros aplicam-se algumas técnicas como máxima verossimilhança, máxima a posteriori e Expectation-Maximization (EM).

\subsubsection{Redes Booleanas}

Assim como as redes Bayesianas, as redes Booleanas (incluindo suas extensões, como BNs com perturbação e PBNs) se tornaram bastante popular nos últimos anos. Por exemplo, o algoritmo REVEAL (Liang et al., 1998) utiliza a informação mútua (Equação 2.18) para recuperar as relações entre os genes, assim como as funções Booleanas, ou tabelas-verdade, que governam a sua dinâmica.

Outra maneira natural para inferir as relações entre os genes é utilizar o coeficiente de determinação, $(\mathrm{CoD})$. Dado $X=\left\{x_{1}, \ldots, x_{n}\right\}$ um conjunto de genes, seja $Z \subseteq X$ um subconjunto de genes preditores e $y=x_{i}, 1 \leq i \leq n$, um gene alvo. $\mathrm{O} \mathrm{CoD}$ é uma medida normalizada do 
quanto as observações em $Z$ podem melhorar na predição/classificação de $y$, se comparado com a ausência de observações. Para qualquer $Z$, o CoD de $y$ é definido por (Dougherty et al., 2000):

$$
\theta_{Z}(y)=\frac{\varepsilon_{\bullet}-\varepsilon_{Z}}{\varepsilon_{\bullet}}
$$

onde $\varepsilon_{\bullet}$ é o erro cometido ao estimar $Y$ na ausência de observações e $\varepsilon_{Z}$ é o erro de Bayes relativo ao conjunto $Z$ para predizer y (o conceito de erro de Bayes é apresentado na Seção 2.5). Segue da definição que $0 \leq \theta_{Z}(y) \leq 1$. Quanto mais alto o valor de $\theta_{Z}(y)$, melhor a predição de $y$ observando-se $Z$. Assim, os maiores CoDs podem ser utilizados para selecionar os genes para compor a funções Booleanas.

Em (Higa et al., 2008) mostramos as dificuldades em utilizar o CoD calculados a partir de uma distribuição de probabilidade estacionária. Utilizando uma abordagem diferente, onde o fator tempo foi levado em consideração, apresentamos o coeficiente de determinação temporal (tCoD) para inferência de GRNs (Higa et al., 2009a).

Outras abordagens baseadas em redes Booleanas podem ser encontradas em podem ser encontradas em (Akutsu et al., 1999), (Dougherty e Xiao, 2006), (Zhao et al., 2006), (Marshall et al., 2007) e (Vahedi et al., 2009).

\subsubsection{Redes genéticas probabilísticas}

Um método baseado no algoritmo SFFS (Sequential Forward Floating Selection, que veremos na próxima seção) e que utiliza a entropia média condicional são apresentados em (Barrera et al., 2007; Lopes et al., 2008, 2011), onde a inferência de redes é realizada considerando as interações regulatórias entre os genes representados por uma PGN (Lopes, 2011). Em geral, para cada gene alvo $Y$, o algoritmo busca um conjunto de genes preditores $\mathbf{X}$, que faça a melhor predição de $Y$. Esta busca é feita através do algoritmo para seleção de características SFFS. Como função critério, é utilizada a entropia condicional média (Martins-Jr, 2008; Martins-Jr et al., 2006). A ideia é penalizar instâncias não observadas nos dados, pois em geral, os dados de expressão gênica possuem milhares de genes e poucas amostras.

Apresentamos apenas alguns algoritmos de inferência, a título de conhecimento e revisão bibliográfica. Existem outras dezenas de algoritmos, e várias outras técnicas são empregadas, como por exemplo, álgebra computacional (Laubenbacher e Stigler, 2004), causalidade Granger (Fujita et al., 2009), clusterização (D'Haeseleer et al., 2000), entre outros.

\subsection{Reconhecimento de padrões}

Como vimos no início deste capítulo, podemos obter dados de expressões gênicas utilizando tecnologias como o microarray. Assim, outros problemas podem ser formulados, como o de classificar padrões a partir de perfis de expressão gênica. No contexto de reconhecimento de padrões, este problema consiste em projetar um classificador $\psi$ que atribua a um vetor de expressão gênica $\mathbf{x}=\left(x_{1}, x_{2}, \ldots, x_{n}\right)$ um rótulo $y \in\{0,1, \ldots, c-1\}$. Para projetar este classificador necessitamos 
de um conjunto de amostras provenientes de células de um mesmo tecido ou tecidos diferentes.

Uma maneira de projetar um classificador $\psi$ é tratar o problema estatisticamente. Neste contexto, um padrão é um vetor aleatório de $n$ características $\mathbf{X}=\left(X_{1}, X_{2}, \ldots, X_{n}\right)$ (Duda et al., 2001). Um conjunto de amostras de treinamento é utilizado, onde cada amostra é composta por um padrão e um rótulo $Y$ conhecido a priori. Esta abordagem é conhecida como classificação supervisionada.

No caso de expressões gênicas, geralmente existe uma grande quantidade de características (genes) e uma quantidade limitada de amostras, dificultando o problema. Além disso, deve-se evitar o overfitting, ou seja, que o classificador seja super-ajustado aos dados utilizados para projetá-lo.

\subsubsection{Classificador Bayesiano}

O conceito de classificador Bayesiano é utilizado nesta tese quando falamos de coeficiente de determinação $(\mathrm{CoD})$. Para entender este conceito, vamos apresentar primeiro algumas definições da teoria de probabilidade e estatística.

A probabilidade a priori de uma classe $y \in Y$ ocorrer, denotada por $P(Y=y)$ ou $P(y)$, é a probabilidade de $y$ ocorrer na ausência de outras observações. Assim,

$$
\sum_{y=0}^{c-1} P(Y=y)=1
$$

no caso em que temos $c$ classes.

A probabilidade de um padrão $\mathbf{x} \in \mathbf{X}$ ocorrer dado que uma classe $y$ ocorreu é denotada por $P(\mathbf{X}=\mathbf{x} \mid Y=y)$ ou $P(\mathbf{x} \mid y)$. Assim, a probabilidade de ocorrer um padrão $\mathbf{x}$ é dado por

$$
P(\mathbf{x})=\sum_{y=0}^{c-1} P(\mathbf{x} \mid y) P(y) .
$$

A probabilidade a posteriori, ou probabilidade de uma classe ser $y$ dado que o padrão é $\mathbf{x}$, é denotada por $P(y \mid \mathbf{x})$. Pela regra de Bayes temos

$$
P(y \mid \mathbf{x})=\frac{P(\mathbf{x} \mid y) P(y)}{P(\mathbf{x})} .
$$

Um classificador Bayesiano $\psi$ atribui um rótulo $y^{*}$ a um novo padrão $\mathbf{x}$ de modo que a probabilidade condicional $P\left(y^{*} \mid \mathbf{x}\right)$ seja a maior. Formalmente,

$$
\psi(\mathbf{x})=y^{*}=\underset{y \in Y}{\arg \max } P(y \mid \mathbf{x}) .
$$

É claro que este classificador pode cometer um erro ao classificar $\mathbf{x}$ com uma classe $y$. A probabilidade deste erro é dada por

$$
\varepsilon_{y}(\mathbf{x})=1-P(y \mid \mathbf{x})
$$

$y=0, \ldots, c-1$. Assim, o erro médio de um classificador Bayesiano, chamado de erro de Bayes, 
é a média ponderada de todos os erros $\varepsilon_{y^{*}}(\mathbf{x})$ :

$$
\varepsilon_{Y}(\mathbf{X})=\sum_{\mathbf{x} \in \mathbf{X}} P(\mathbf{x}) \varepsilon_{y^{*}}(\mathbf{x})
$$

onde $y^{*}$ é dado pela Eq. 2.28.

O erro a priori de um classificador Bayesiano mede o erro quando este necessita classificar uma amostra na ausência de qualquer outra observação. Neste caso, $\psi$ atribui o valor mais observado de $Y$, ou seja,

$$
\psi_{Y}=y^{*}=\underset{y \in Y}{\arg \max } P(y) .
$$

Assim, o erro a priori cometido é

$$
\varepsilon_{Y}=1-\max _{y \in Y} P(y)
$$

O classificador Bayesiano é estatisticamente ótimo, pois sempre atribui ao $\mathbf{x}$ a classe cuja probabilidade é a maior. No entanto, é necessário que se conheça a distribuição de probabilidade entre os padrões e as classes, o que não acontece na prática. Na maioria dos casos, estas probabilidades são estimadas através de dados de treinamento.

\subsubsection{Seleção de características}

Um problema bastante conhecido na área de reconhecimento de padrões é o de seleção de características. Dado um conjunto $X$ de características, o objetivo é selecionar um subconjunto $Z \subset X$, de acordo com algum critério. Diversos algoritmos têm sido propostos para lidar com este problema utilizando diversas técnicas, como busca exaustiva, simulated annealing, algoritmos genéticos, algoritmos gulosos, entre outros. Em geral, estes algoritmos são utilizados como um pré-processamento dos dados quando deseja-se reduzir a dimensionalidade. No contexto deste trabalho as características são os genes, ou seja, $X=\left\{X_{1}, X_{2}, \ldots, X_{n}\right\}$. Como veremos mais adiante, desenvolvemos um algoritmo de inferência de GRN baseado no paradigma de crescimento de semente. Uma semente é um subconjunto pequeno de genes e "crescer a semente" significa adicionar outros genes a este conjunto, de acordo com algum critério. Desta maneira, precisamos selecionar genes para agregar à semente, ou seja, precisamos selecionar características.

Dado um conjunto $X$ de $n$ características, vamos denotar por $\mathcal{X}_{d}$ o conjunto de todos os possíveis subconjuntos de $X$ de tamanho $d$. Seja $J\left(Z^{\prime}\right)$ uma função critério que avalia um subconjunto $Z^{\prime} \in \mathcal{X}_{d}$. Sem perda de generalidade, vamos considerar que um valor alto de $J$ indica um subconjunto de características melhor. Sendo assim, podemos formular o problema de seleção de características da seguinte maneira: encontre o subconjunto $Z_{d}^{*}$ para o qual

$$
J\left(Z_{d}^{*}\right)=\max _{Z^{\prime} \in \mathcal{X}_{d}} J\left(Z^{\prime}\right) .
$$

Assumindo que uma função critério adequada tenha sido escolhida de forma a validar o subconjunto de características, o problema de seleção de características reduz-se a um problema de busca de um subconjunto ótimo de acordo com a medida adotada. 
Existem métodos ótimos e subótimos para seleção de subconjuntos de características. Entre os ótimos exitem métodos baseados na busca exaustiva, que são apenas viáveis quando o número de características é pequeno. Dessa maneira, os métodos subótimos são bastante utilizados por serem computacionalmente mais eficientes quando o número de características é grande. Métodos baseados em busca sequencial são bastante utilizados e possuem o mesmo princípio de adicionar e remover características para/de um subconjunto atual. A seguir, apresentaremos um método conhecido como IFFS (Improved Forward Floating Selection), que é baseado no tradicional SFFS (Sequential Forward Floating Selection), com um passo adicional para "substituir uma característica fraca" (Nakariyakul e Casasent, 2009).

\section{Busca sequencial}

Antes de apresentarmos o algoritmo IFFS vamos apresentar algumas definições e os algoritmos SFS (Sequential Forward Selection) (Whitney, 1971) e SBS (Sequential Backward Selection) (Marill e Green, 1963), que fazem parte do IFFS. Para um dado subconjunto de características $Z_{d}$, seja $x^{+}$a característica tal que

$$
x^{+}=\underset{x \in X-Z_{d}}{\arg \max } J^{+}\left(Z_{d}, x\right),
$$

onde $J^{+}\left(Z_{d}, x\right)=J\left(Z_{d} \cup\{x\}\right)$ denota a função critério usada para validar o subconjunto obtido adicionando $x$ ao subconjunto $Z_{d}$. Então, iremos definir $A D D\left(Z_{d}\right)$ como uma operação que adiciona a característica $x^{+}$ao atual subconjunto $Z_{d}$ para obter o subconjunto $Z_{d+1}$ se

$$
A D D\left(Z_{d}\right) \equiv Z_{d} \cup\left\{x^{+}\right\}=Z_{d+1},
$$

para $Z_{d}, Z_{d+1} \subset X$. De maneira análoga, para um dado subconjunto de características $Z_{d}$, seja $x^{-}$a característica tal que

$$
x^{-}=\underset{x \in Z_{d}}{\arg \max } J^{-}\left(Z_{d}, x\right),
$$

onde $J^{-}\left(Z_{d}, x\right)=J\left(Z_{d}-\{x\}\right)$ denota a função critério usada para validar o subconjunto obtido removendo $x$ de $Z_{d}$. Então, iremos definir $R E M\left(Z_{d}\right)$ como uma operação que remove a característica $x^{-}$do atual subconjunto $Z_{d}$ para obter o subconjunto $Z_{d-1}$ se

$$
\operatorname{REM}\left(Z_{d}\right) \equiv Z_{d}-\left\{x^{-}\right\}=Z_{d-1},
$$

onde $Z_{d}, Z_{d-1} \in X$.

O algoritmo SFS têm como parâmetro um inteiro $d$, que indica a quantidade de elementos do subconjunto final, e adiciona iterativamente uma característica por vez. A saída do algoritmo é um subconjunto $Z_{d} \subset X$ contendo $d$ características, tal que $Z_{d}$ otimiza o valor da função $J\left(Z_{d}\right)$ e $X=\left\{X_{1}, X_{2}, \ldots X_{n}\right\}$ é o conjunto de características em questão. Podemos descrever o SFS em passos da seguinte maneira

Passo 1: $Z_{0} \leftarrow \emptyset, k \leftarrow 1$; 
Passo 2: $Z_{k} \leftarrow A D D\left(Z_{k-1}\right), k \leftarrow k+1$;

Passo 3: Se $k<d$ volte para o Passo 2; caso contrário, termine o algoritmo.

Assim como o algoritmo SFS, o SBS também tem como saída um subconjunto $Z_{d} \subset X$ de características. A diferença é que no SBS as características são removidas iterativamente a partir do conjunto $X$, até que o subconjunto resultante contenha $d$ características. Podemos descrever o algoritmo SBS em passos da seguinte maneira:

Passo 1: $Z_{n} \leftarrow X, k \leftarrow n-1$;

Passo 2: $Z_{k} \leftarrow R E M\left(Z_{k+1}\right), k \leftarrow k-1$;

Passo 3: Se $k>d$ volte para o Passo 2; caso contrário, termine o algoritmo.

Assim como em outros métodos sequenciais, os algoritmos SFS e SBS sofrem do chamado efeito nesting (uma vez que uma característica tenha sido selecionada, ela não pode ser mais descartada do conjunto final). No SFS, uma vez que uma característica tenha sido adicionada ela não será mais removida do subconjunto. No caso do SBS, uma característica removida jamais será adicionada ao subconjunto. Para contornar este problema, foram propostos métodos conhecidos como algoritmos $(l, r)$ (Devijver e Kittler, 1982), onde características são adicionadas e removidas sucessivamente. Esta mesma ideia é a base para algoritmos de busca flutuante.

\section{Busca sequencial flutuante}

Um algoritmo flutuante bastante popular é a busca sequencial flutuante para frente (SFFS) (Pudil et al., 1994). No início da execução deste algoritmo temos um conjunto vazio $Z_{0}$, e aplicamos o algoritmo SFS até obtermos um subconjunto $Z_{2}$ com duas características. Para subconjuntos contendo mais do que duas características, o algoritmo SBS é executado com o objetivo de remover uma característica considerada ruim de acordo com a função critério. O SFFS aplica os algoritmos SFS e SBS de maneira alternada, até que uma condição de parada seja atingida. Um parâmetro opcional $\Delta \in[0, n-d]$ pode ser utilizado para controlar a condição de parada. Podemos descrever o SFFS nos seguintes passos

Passo 1: $Z_{0} \leftarrow \emptyset, k \leftarrow 0$;

Passo 2: $Z_{k+1}=A D D\left(Z_{k}\right), k \leftarrow k+1$;

Passo 3: Repita $Z_{k-1}=\operatorname{REM}\left(Z_{k}\right), k \leftarrow k-1$, enquanto este passo otimizar o valor da função critério para subconjuntos menores;

Passo 4: Se $k<d+\Delta$ vá para o Passo 2; caso contrário, termine o algoritmo.

A versão oposta do SFFS é a busca sequencial flutuante para trás (SBFS - Sequential Backward Floating Selection). A diferença é que este algoritmo parte do conjunto completo de características $X$. O seu funcionamento é similar ao SFFS, também aplicando o SFS e SBS de maneira alternada.

Neste trabalho, utilizamos um algoritmo conhecido como IFFS, que é uma melhoria do algoritmo SFFS. Como mencionamos, um passo adicional foi incluído neste algoritmo com o objetivo 
de "substituir uma característica fraca". Para ilustrar como o algoritmo funciona, vamos usar um exemplo adaptado de (Nakariyakul e Casasent, 2009). Vamos assumir que os primeiros quatro subconjuntos selecionados pelo SFS sejam $\left\{X_{1}\right\},\left\{X_{1}, X_{4}\right\},\left\{X_{1}, X_{4}, X_{5}\right\}$ e $\left\{X_{1}, X_{4}, X_{5}, X_{7}\right\}$. Vamos assumir que os correspondentes valores da função critério $J$ são 4, 6, 9 e 10, respectivamente, e que remover uma característica usando o SBS não melhora o valor da função critério.

Em um primeiro passo (adicionando características), o SFS é usado para adicionar uma característica a este subconjunto de quatro características, tal que esta característica maximize o valor da função critério $J$. Vamos assumir que a característica $X_{6}$ seja escolhida pelo SFS e que o valor de $J$ para o novo subconjunto de cinco características seja 13, ou seja, $J\left(\left\{X_{1}, X_{4}, X_{5}, X_{7}, X_{6}\right\}\right)=13$.

Em um segundo passo (removendo características), o SBS é aplicado como no algoritmo SFFS para tentar remover condicionalmente uma característica do conjunto de cinco características com o objetivo de obter um subconjunto melhor de quatro características, ou seja, um subconjunto cujo valor de $J$ seja maior que 10 . Para este exemplo, vamos assumir que removendo a característica $X_{4}$ de $\left\{X_{1}, X_{4}, X_{5}, X_{7}, X_{6}\right\}$ obtemos um valor maior de $J$ do que removendo qualquer outra característica deste subconjunto; além disso, vamos assumir que o valor de $J$ para este subconjunto é 11 , ou seja, $J\left(\left\{X_{1}, X_{5}, X_{7}, X_{6}\right\}\right)=11$. Assim, este novo subconjunto de quatro características se torna o melhor subconjunto de quatro características. Este passo é repetido para tentar encontrar um subconjunto melhor de três características, etc. Para este exemplo, vamos assumir que o SBS não encontra um subconjunto melhor de três características.

Em um terceiro passo (substituindo uma característica fraca), o IFFS remove condicionalmente uma característica por vez do subconjunto de características atual e usa o SFS para adicionar uma característica a cada subconjunto resultante. Se o valor de $J$ do novo subconjunto é maior do que o valor atual, este novo subconjunto é utilizado como o subconjunto atual. Para o nosso exemplo, este passo considera todos os possíveis subconjuntos de três características a partir do subconjunto de quatro características: $\left\{X_{5}, X_{7}, X_{6}\right\},\left\{X_{1}, X_{7}, X_{6}\right\},\left\{X_{1}, X_{5}, X_{6}\right\}$ e $\left\{X_{1}, X_{5}, X_{7}\right\}$. Usando o SFS, adicionamos condicionalmente uma característica a cada um desses quatro subconjuntos para produzir quatro novos subconjuntos de de quatro características. Se o maior valor de $J$ para qualquer um desses quatro subconjuntos é maior do que 11 então o subconjunto correspondente se torna o melhor subconjunto de quatro características. Vamos assumir que $J\left(\left\{X_{5}, X_{7}, X_{6}\right\}\right)=8,5$ e que $J\left(\left\{X_{5}, X_{7}, X_{6}, X_{9}\right\}\right)=11,5$ é o maior valor entre os quatro novos subconjuntos de quatro características. Assim, $J\left(\left\{X_{5}, X_{7}, X_{6}\right\}\right)=8,5$ é menor do que $J\left(\left\{X_{1}, X_{4}, X_{5}\right\}\right)=9$ (o melhor subconjunto de três características), mas $J\left(\left\{X_{5}, X_{7}, X_{6}, X_{9}\right\}\right)=11,5$ é maior do que $J\left(\left\{X_{1}, X_{5}, X_{7}, X_{6}\right\}\right)=11$. Dessa forma, o novo melhor subconjunto de quatro características passa a ser $\left\{X_{5}, X_{7}, X_{6}, X_{9}\right\}$, enquanto que o melhor subconjunto de três características continua a ser $\left\{X_{1}, X_{4}, X_{5}\right\}$. O SFFS não poderia produzir o subconjunto $\left\{X_{5}, X_{7}, X_{6}, X_{9}\right\}$, uma vez que o SBS não levaria ao subconjunto $\left\{X_{5}, X_{7}, X_{6}\right\}$ pois $J\left(\left\{X_{5}, X_{7}, X_{6}\right\}\right)<J\left(\left\{X_{1}, X_{4}, X_{5}\right\}\right)$; portanto, o SFFS não consideraria adicionar a característica $X_{9}$ ao subconjunto $\left\{X_{5}, X_{7}, X_{6}\right\}$. Esta é a vantagem do IFFS sobre o SFFS. O IFFS substitui a "característica fraca" $X_{1}$ em $\left\{X_{1}, X_{5}, X_{7}, X_{6}\right\}$ pela característica $X_{9}$, resultando em um subconjunto melhor: $\left\{X_{5}, X_{7}, X_{6}, X_{9}\right\}$. Na Fig. 2.11 apresentamos o fluxograma da execução do IFFS. 


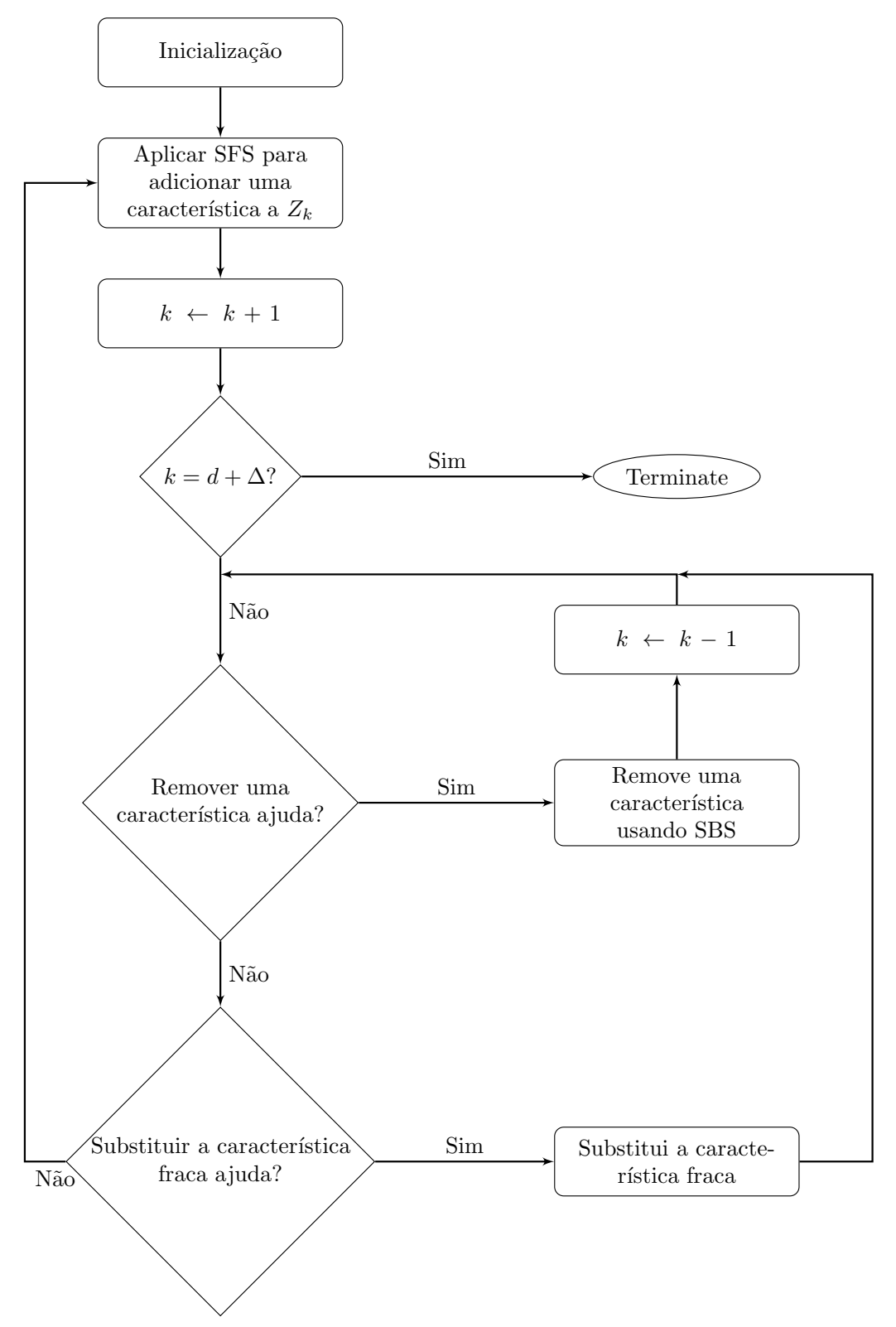

Figura 2.11: Fluxograma do algoritmo IFFS (Nakariyakul e Casasent, 2009).

\subsection{Problema de satisfação de restrições}

Muitos problemas em Ciência da Computação e outras áreas podem ser modelados como problemas de satisfação de restrições (CSP - constraint satisfaction problem). Nesta seção, iremos formalizar o conceito de CSP e apresentar técnicas utilizadas para encontrar soluções para tais problemas. Como veremos no próximo capítulo, estas técnicas podem ser utilizadas para encontrar tBNs (Seção 2.3.2) que expliquem dados temporais de expressão gênica.

Formalmente, um CSP é definido por um conjunto de variáveis, $V=\left\{V_{1}, V_{2}, \ldots, V_{n}\right\}$, e um conjunto de restrições $R=\left\{R_{1}, R_{2}, \ldots, R_{m}\right\}$. Além disso, cada variável $V_{i}$ possui um domínio não vazio $D_{i}$ de possíveis valores que ela pode assumir. Um estado é uma atribuição para algumas (parcial) ou todas (completa) as variáveis, $\left\{V_{i}=v_{i}, V_{j}=v_{j}, \ldots\right\}, 1 \leq i, j \leq n, v_{i} \in D_{i}$ e $v_{j} \in D_{j}$. Uma atribuição que não viola nenhuma restrição é chamada de atribuição consistente. Uma 
solução do CSP é uma atribuição completa e consistente. Alguns problemas também exigem que a solução maximize alguma função objetivo.

\subsubsection{Busca de soluções para o CSP}

A busca por uma solução (ou soluções) do CSP é feita através de algoritmos de busca, atribuindo-se valores para as variáveis e verificando se as restrições são satisfeitas. Assim, uma variável é escolhida através de alguma ordenação ou heurística, e então um valor do seu domínio é atribuído à ela, também escolhido através de alguma ordenação específica ou heurística. Descreveremos a seguir algumas técnicas para a busca de soluções do CSP, apresentando primeiramente os tipos de variáveis e restrições que podem aparecer na formulação de um CSP.

\section{Tipos de variáveis e restrições}

O tipo mais simples de CSP envolve variáveis discretas que possuem domínios finitos. Se o tamanho do maior domínio, para qualquer variável, é $d$, então o número de possíveis atribuições completas é $O\left(d^{n}\right)$, ou seja, exponencial no número de variáveis. Um tipo de CSP de domínio finito é o CSP Booleano, onde as variáveis podem assumir apenas os valores verdadeiro ou falso. Por exemplo, o famoso problema 3-SAT (Cook, 1971), da classe NP-Completo, pode ser visto como um CSP Booleano. Assim, no pior caso, não podemos resolver CSPs de domínios finitos em tempo menor que exponencial. No entanto, na maioria das aplicações práticas, algoritmos para busca de soluções em CSPs podem resolver problemas de ordem de grandeza maior do que os resolvidos por algoritmos genéricos de busca (Russell e Norvig, 2002).

Variáveis discretas também podem ter domínio infinito, por exemplo, o conjunto dos inteiros ou o conjunto de cadeias de caracteres de tamanho ilimitado. Neste caso, não é possível enumerar as atribuições e verificar se satisfazem as restrições. Dessa maneira, aplicam-se formas de restringir os domínios, por exemplo, colocando limites superiores e inferiores para os mesmos.

Podemos ter também variáveis contínuas. Os CSPs em domínio contínuos mais conhecidos são os problemas de programaçâao linear, onde as restrições devem ser desigualdades lineares, formando uma região convexa. Problemas de programação linear podem ser resolvidos em tempo polinomial no número de variáveis.

Com relação às restrições, existem tipos padronizados de restrições, que nos permite criar técnicas genéricas para solucionar CSPs. O tipo mais simples é a restrição unária, que restringe o valor de uma variável a um único valor. Uma restrição unária pode ser facilmente satisfeita eliminando todos os valores conflitantes do domínio da variável. Uma restrição binária relaciona duas variáveis, por exemplo, $V_{i} \neq V_{j}$. Um exemplo clássico que envolve restrições binárias é a coloração de mapas. Neste problema, representamos mapas como grafos planares, e precisamos colorir as regiões (vértices) do mapa tal que duas regiões adjacentes não tenham a mesma cor. No contexto de CSP, um grafo de restriçôes pode ser utilizado para visualizar o problema. Neste grafo, os vértices representam as variáveis e as arestas as restrições. Um grafo de restrições para o problema de coloração de mapas é ilustrado na Fig. 2.12. Nesta figura temos quatro regiões indicadas por A, B, C e D; regiões adjacentes são conectadas por uma aresta. O problema consiste em colorir este mapa utilizando as cores vermelho, verde e azul. Assim, uma possível solução seria 
$\mathrm{A}=$ vermelho, $\mathrm{B}=$ verde, $\mathrm{C}=$ vermelho e $\mathrm{D}=$ azul.

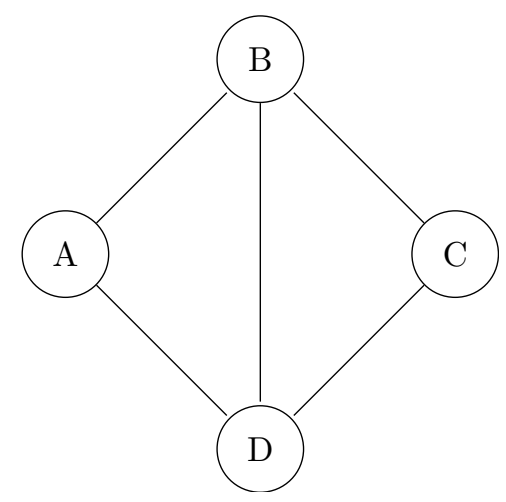

Figura 2.12: Exemplo de um grafo de restrições para uma instância do problema de coloração de mapas. As regiões (vértices) adjacentes são ligadas por uma aresta.

No caso de CSPs envolvendo restrições entre mais do que duas variáveis um hiper grafo de restrições pode ser utilizado. No entanto, usando variáveis auxiliares é possível converter um CSP com restrições não binárias em um CSP com restrições binárias (Russell e Norvig, 2002).

\subsubsection{Busca de soluções usando backtracking}

Nesta seção iremos formular o CSP como um problema de busca, possibilitando que qualquer algoritmo de busca (como busca em largura ou em profundidade) possa ser utilizado para encontrar soluções do CSP. Neste contexto de algoritmos de busca, podemos notar que o fator de ramificação no nível mais alto é $n d$, pois qualquer um $\operatorname{dos} d$ valores podem ser atribuídos a qualquer variável. No próximo nível, o fator de ramificação é $(n-1) d$, e assim por diante. Dessa maneira, podemos gerar uma árvore com $n ! \cdot d^{n}$ folhas, mesmo que exista apenas $d^{n}$ possibilidades.

O problema desta formulação é que não estamos levando em consideração uma propriedade comum em todos os CSPs, que é a comutatividade. Um problema é comutativo se a ordem da aplicação de um conjunto de ações não altera o resultado final. Assim, todo algoritmo de busca em CSP gera sucessores (estados) considerando as possíveis atribuições para uma única variável a cada nó da árvore de busca. No exemplo da Fig. 2.12, na raiz da árvore poderíamos escolher entre $\mathrm{A}=$ vermelho, $\mathrm{A}=$ verde e $\mathrm{A}=$ azul; mas jamais escolheríamos entre $\mathrm{A}=$ vermelho e $\mathrm{B}$ $=$ azul. Assim, o número de folhas é $d^{n}$, como desejamos.

O termo backtracking é usado para um algoritmo de busca em profundidade (DFS - depth first search) que escolhe valores para uma variável de cada vez e então recua (backtracks) quando não existe uma atribuição possível. A Fig. 2.13 ilustra parte de uma árvore de busca gerada pelo algoritmo backtracking para colorir o grafo da Fig. 2.12. Seguindo o ramo mais à esquerda da árvore encontramos uma solução para o CSP.

Algumas questões que surgem naturalmente são:

- Qual variável deve ser selecionada a seguir, e em qual ordem os valores devem ser testados?

- Quais são as implicações de uma atribuição para com as variáveis que ainda não foram selecionadas? 


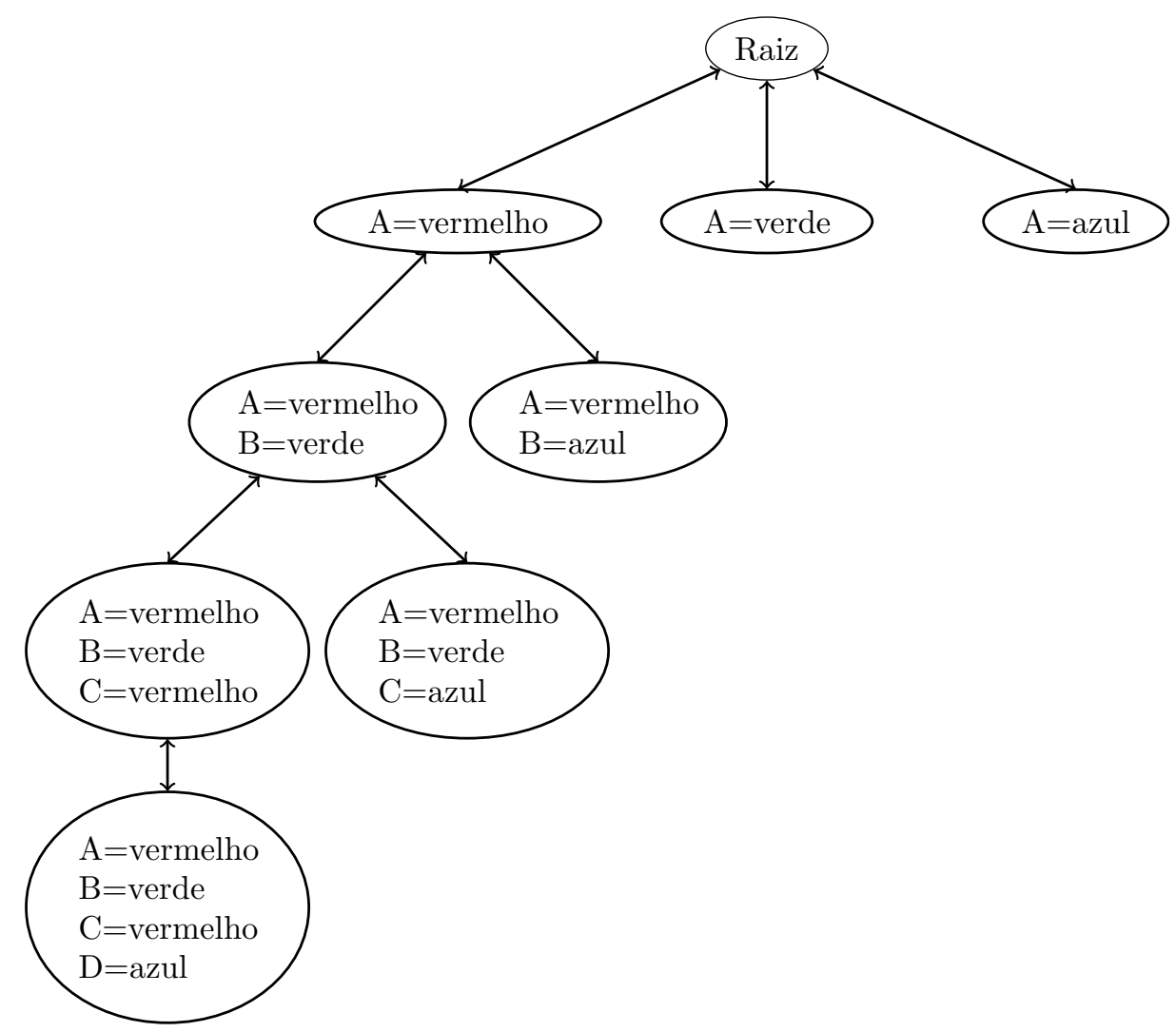

Figura 2.13: Backtracking sendo aplicado para colorir o grafo da Fig. 2.12 representado por uma árvore.

- Quando ocorre uma falha - ou seja, um estado é alcançado e não há valores possíveis para a variável - a busca pode evitar que esta falha ocorra novamente?

Vamos comentar brevemente a respeito destas questões. Para o exemplo da coloração de mapas (Fig. 2.12), vamos supor que as duas primeiras atribuições sejam $\mathrm{A}=$ vermelho e $\mathrm{B}=$ verde. Sendo assim, podemos escolher a cor azul para D, pois esta é a única possibilidade, ao invés de tentarmos uma atribuição para C. Esta ideia intuitiva de escolher a variável com o menor número de valores possíveis é chamada de heurística de menores valores restantes (MRV - minimum remaining values). Esta heurística tende a selecionar a variável com maior chance de causar uma falha. De fato, se $V_{i}$ é uma variável com zero valores possíveis, ela será escolhida e uma falha será detectada, evitando a busca através de outras variáveis pois a falha ocorrerá de qualquer maneira no momento em que $V_{i}$ for selecionada.

A heurística MRV não ajuda na escolha da coloração da primeira região, pois inicialmente cada região possui três cores possíveis. Neste caso, a heurística de grau pode ajudar, tentando reduzir o fator de ramificação escolhendo a variável envolvida no maior número de restrições com outras variáveis que não foram selecionadas. Em geral, a heurística MRV é melhor, mas a heurística de grau pode ser utilizada em caso de empates (Russell e Norvig, 2002).

Uma vez que a variável é escolhida, o algoritmo deve selecionar um valor para ela. A maneira mais simples é selecionar um valor aleatoriamente, dentre os valores possíveis, que obedeça a(s) restrição(ões). Uma heurística, conhecida como valor menos restritivo, também pode ser utilizada. Esta heurística escolhe o valor que elimina a menor quantidade de escolhas para as 
variáveis vizinhas, considerando o grafo de restrições. Vale notar que se estamos interessados em encontrar todas as soluções viáveis para o CSP, e não apenas uma única solução, a ordem não importa pois teremos que considerar todos os valores de qualquer maneira. O mesmo acontece se não há solução viável para o problema.

\subsubsection{Propagando informação através de restrições}

Até o momento, o algoritmo backtracking considera apenas as restrições da variável escolhida. Porém, olhando para outras restrições podemos melhorar o procedimento de busca. Para isso, técnicas como a verificação prematura e a propagação de restrições são utilizadas.

\section{Verificação prematura}

A verificação prematura funciona da seguinte maneira: quando uma variável $X_{i}$ recebe um valor, olhamos para cada variável $X_{j}$ que ainda não possui um valor e que esteja conectada a $X_{i}$ através de uma restrição e removemos do domínio de $X_{j}$ qualquer valor que seja inconsistente com o valor de $X_{i}$. Por exemplo, na Fig. 2.12, suponha que o algoritmo tenha atribuído $\mathrm{A}=$ vermelho e $\mathrm{B}=$ verde. Se em seguida atribuirmos $\mathrm{C}=$ azul, podemos observar que o domínio de $\mathrm{D}$ passa a ser vazio. Assim, detectamos uma falha sem ter que atribuir um valor à variável $\mathrm{D}$, e o algoritmo recua imediatamente.

\section{Propagação de restrições}

Apesar de ajudar a detectar inconsistências, a verificação prematura não é capaz de detectar todas elas. Vamos considerar o grafo de restrições da Fig. 2.14 para o problema da coloração de mapas. Vamos supor que tenhamos $\mathrm{A}=$ vermelho e $\mathrm{C}=$ verde. Usando a verificação prematura, os domínios de B e D são reduzidos à cor azul. Mas B e D são adjacentes e portanto não podem ter a mesma cor. A verificação prematura não detectaria esta inconsistência.

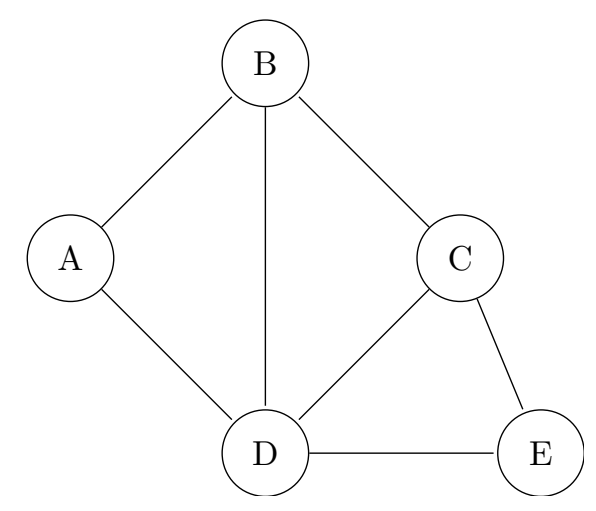

Figura 2.14: Grafo de restrições para um problema de coloração de mapas.

A propagação de restrições é a propagação das implicações de uma restrição sobre uma variável para outras variáveis. Neste caso, temos que propagar a partir de A e C sobre a B e D (como é feito na verificação prematura), e então sobre a restrição entre B e D para detectar a inconsistência. Além disso, esta propagação deve ser feita rapidamente, pois não faz sentido gastar mais tempo para propagar as restrições do que para realizar uma simples busca. 
Para realizar a propagação de restrições de maneira rápida, é utilizada a ideia de consistência de arco. O termo "arco" se refere a um arco direcionado no grafo de restrições. Dados os domínios atuais de duas variáveis $X_{i}$ e $X_{j}$, um arco de $X_{i}$ para $X_{j}$ é consistente se, para todo $x_{i}$ no domínio de $X_{i}$, existe algum $y_{i}$ no domínio de $Y_{i}$ consistente com $x_{i}$. Na Fig. 2.14, se tivermos A $=$ vermelho e $\mathrm{C}=$ verde, os domínios de $\mathrm{D}$ e $\mathrm{E}$ são $\{$ azul $\}$ e $\{$ vermelho, azul $\}$, respectivamente. No caso de $\mathrm{D}$ = azul, existe uma atribuição consistente para $\mathrm{E}$, isto é, $\mathrm{E}=$ vermelho; portanto, o arco de D para E é consistente. Por outro lado, o arco de $\mathrm{E}$ para D não é consistente, pois para a atribuição $\mathrm{E}=$ azul não existe nenhuma atribuição consistente para D. Podemos tornar este arco consistente removendo o valor azul do domínio de E. Também podemos aplicar esta ideia no arco de D para B. Ambas as variáveis possuem o domínio \{azul\}. O resultado é que azul deve ser eliminado do domínio de $\mathrm{D}$, deixando o domínio vazio. Assim, detectamos uma inconsistência que não seria detectada utilizando apenas a verificação prematura.

A verificação de consistência de arco pode ser aplicada como uma etapa de pré-processamento antes do início do processo de busca ou como uma etapa de propagação depois de cada atribuição durante a busca (Russell e Norvig, 2002). Um algoritmo conhecido como AC-3 (Mackworth, 1977) realiza a verificação de consistência de arco em tempo $O\left(n^{2} d^{3}\right)$ no pior caso, onde $n$ é o número de variáveis e $d$ o tamanho do maior conjunto domínio. Como o problema 3-SAT é um caso especial de CSP, não esperamos encontrar um algoritmo polinomial para decidir se um dado CSP é consistente. Assim, é de se esperar que a consistência de arco não revela todas as inconsistências possíveis.

Apresentamos nesta seção a definição formal de CSP e também apresentamos brevemente algumas técnicas e algoritmos utilizados para encontrar soluções de CSP. Para uma leitura mais detalhada sugerimos (Marriott e Stuckey, 1998; Russell e Norvig, 2002; Tsang, 1993). 


\section{Capítulo 3}

\section{O ciclo celular da levedura}

Neste capítulo, apresentaremos dois modelos para o ciclo celular da levedura (Saccharomyces cerevisiae). O primeiro, é um modelo determinístico baseado em redes Booleanas com limiar, proposto por (Li et al., 2004). O segundo, é um modelo estocástico, proposto por (Zhang et al., 2006) que pode ser visto como uma extensão do primeiro. Apesar da simplicidade, estes modelos apresentaram resultados interessantes, e auxiliaram o desenvolvimento do nosso trabalho. Propomos melhorias com relação a estes modelos, apresentadas no Capítulo 4 e também utilizamos este modelo para o desenvolvimento do algoritmo de inferência, apresentado no Capítulo 5.

Na Seção 3.1, apresentaremos de maneira breve o processo do ciclo celular. Em seguida, na Seção 3.2, apresentamos o modelo determinístico para o ciclo celular da levedura, e na Seção 3.3 apresentamos o modelo estocástico.

\subsection{Ciclo celular}

O ciclo celular é uma série de eventos que ocorre em uma célula, levando à divisão desta. Nesta seção, estaremos descrevendo o ciclo celular de organismos eucariotos; em procariotos o ciclo celular ocorre através de um processo chamado fissão binária ou bipartição. O ciclo celular é um processo vital pelo qual um zigoto se desenvolve tornando-se um organismo maduro, assim como células (do sangue, da pele, por exemplo) são renovadas.

Este processo de divisão celular consiste de quatro fases: $G_{1}$ (na qual a célula cresce e, sob condições apropriadas, a divisão celular tem início), S (na qual o DNA é sintetizado e os cromossomos replicados), $\mathrm{G}_{2}$ (um "intervalo" entre S e M), e M (mitose, onde os cromossomos se separam e a célula se divide em duas). Após a fase $M$, a célula retorna para a fase $G_{1}$, esperando por condições apropriadas para que uma nova divisão ocorra. A Fig. 3.1 ilustra um esquema das fases do ciclo celular. Ainda é possível que a célula entre em uma fase chamada de $\mathrm{G}_{0}$, após a fase M. Quando uma célula para de se dividir, ela pode entrar nesta fase por um longo período (indeterminado) de tempo, como no caso dos neurônios. Isso também é comum em células que já estão completamente diferenciadas.

As três primeiras fases, $\mathrm{G}_{1}, \mathrm{~S}$ e $\mathrm{G}_{2}$, são conhecidas como interfase, onde a célula se prepara para que a divisão ocorra, de fato, na fase M. A mitose, por sua vez, é composta por uma sequência de passos: prófase, metáfase, anáfase, telófase e citocinese. 


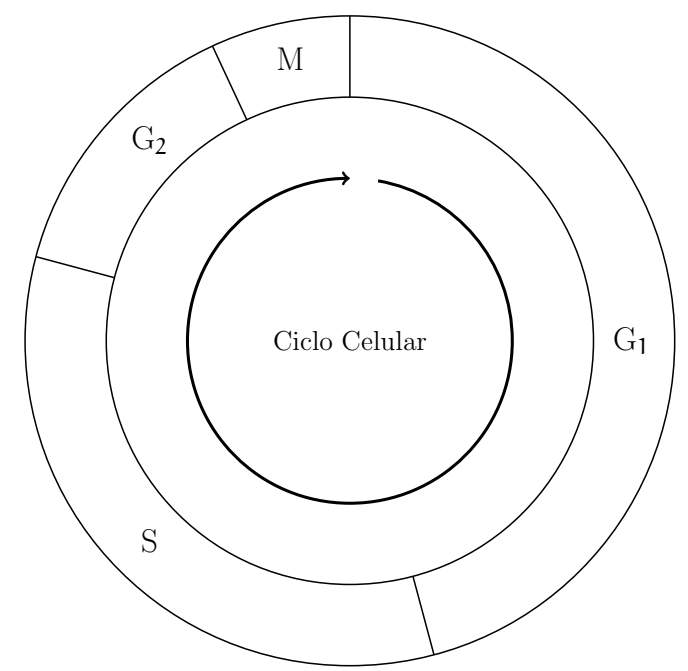

Figura 3.1: Fases do ciclo celular: $G_{1}, S, G_{2}$ e M. Eventualmente, uma fase $\mathrm{G}_{0}$ (não ilustrada na figura) ocorre após a fase $M$.

A prófase é caracterizada pela individualização dos cromossomos, pelo aparecimento do fuso mitótico e pela decomposição da membrana nuclear. É a etapa mais longa da mitose. Na metáfase, os centrômeros dos cromossomos se ligam às fibras cromossômicas. Durante a anáfase, as cromátides irmãs são levadas para polos opostos da célula. Na telófase, a membrana nuclear é reconstruída, as fibras cromossômicas desaparecem e os cromossomos começam a se descondensar. Por fim, a citocinese é a divisão da célula em duas células filhas.

Além das fases do ciclo celular apresentadas na Fig. 3.1, também existem os checkpoints, que são mecanismos de controle para garantir que a divisão ocorra corretamente. Células que contenham danos no DNA na fase $\mathrm{G}_{1}$ não podem replicar o DNA, e aquelas que continuam danificadas em $\mathrm{G}_{2}$ não podem entrar na mitose (Murray, 1994). Estes danos no DNA podem causar câncer (Kastan e Bartek, 2004). Assim, estes checkpoints devem impedir que a divisão celular siga adiante quando a célula encontra-se defeituosa.

O primeiro checkpoint é o $G_{1}$ checkpoint, ao final da fase $\mathrm{G}_{1}$ e antes da fase S. Neste ponto que a célula pode entrar na fase $\mathrm{G}_{0}$ ou ficar "presa", esperando por condições favoráveis para que a célula entre na fase S. No caso de leveduras, este checkpoint é chamado START. O segundo checkpoint é o $G_{2}$ checkpoint, localizado ao final da fase $\mathrm{G}_{2}$. Este checkpoint previne que as células iniciem a mitose quando elas encontram danos no DNA durante a fase $\mathrm{G}_{2}$, ou quando elas avançam para a fase $G_{2}$ com algum dano não reparado causado durante as fases $G_{1}$ ou S (Kastan e Bartek, 2004).

\subsection{Modelo determinístico}

Existem aproximadamente 800 genes envolvidos no processo de ciclo celular da levedura (Spellman et al., 1998). No entanto, o número de reguladores chave que são responsáveis pelo controle deste processo complexo é muito menor ( $\mathrm{Li}$ et al., 2004). O modelo do ciclo celular da levedura proposto por (Li et al., 2004) é baseado em uma rede Booleana com limiar (ver Seção 2.3.2) composta por 11 genes, como mostra a Fig. 3.2. O significado das arestas é o mesmo encontrado na Fig. 2.8. Os 
11 genes $x_{1}, \ldots, x_{11}$ são Cln3, MBF, SBF, Cln1, Cdh1, Swi5, Cdc20, Clb5, Sic1, Clb1 e Mcm1, respectivamente. O nó "cell-size" foi introduzido apenas para indicar um checkpoint para o início do ciclo celular. Neste texto, utilizamos a palavra "gene" por simplificação, pois na realidade podemos ter complexos proteicos como, por exemplo, o MBF e o SBF.

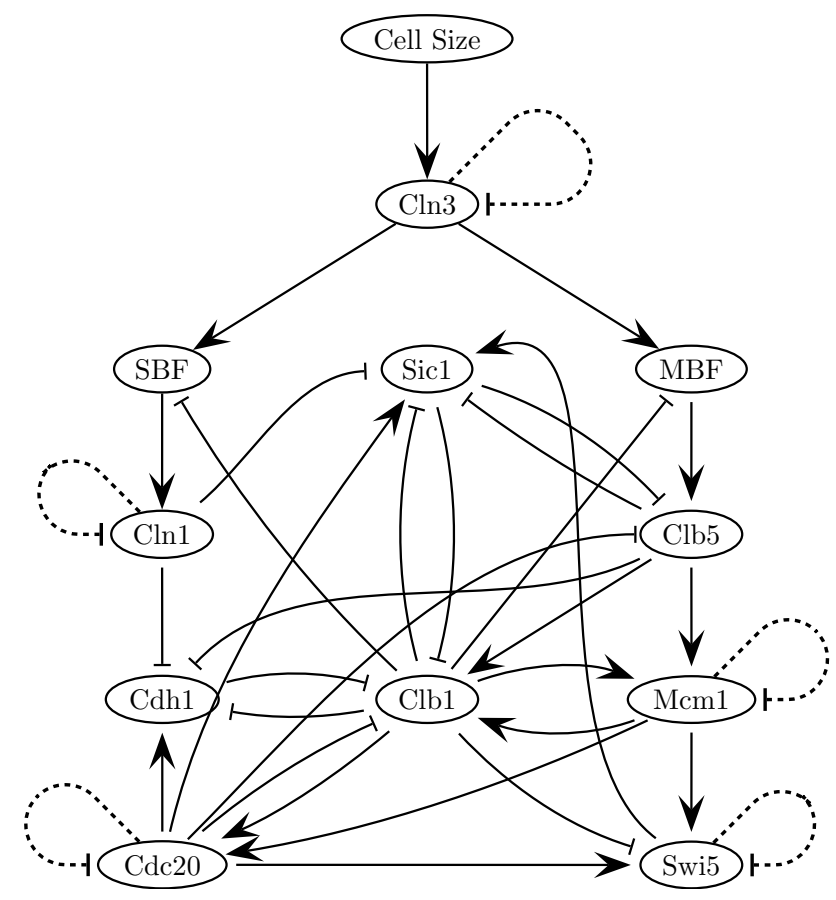

Figura 3.2: Rede do ciclo celular da levedura proposto por (Li et al., 2004).

Considerando o modelo de redes Booleanas restritas, Li et al. (2004) estudaram a dinâmica da rede. Eles descobriram que há sete atratores nesta rede, mostrados na Tabela 3.1, onde cada linha representa um atrator, e a primeira coluna indica o tamanho da bacia de atração. Neste caso, todos os atratores são formados por um único estado (atratores singletons). Como podemos ver, existe uma bacia grande composta por 1.764 ou $\approx 86 \%$ dos estados. De acordo com Li et al. (2004) este atrator corresponde ao estado biológico $\mathrm{G}_{1}$ estacionário.

\begin{tabular}{cccccccccccc} 
Tam. bacia & Cln3 & MBF & SBF & Cln1 & Cdh1 & Swi5 & Cdc20 & Clb5 & Sic1 & Clb1 & Mcm1 \\
\hline 1.764 & 0 & 0 & 0 & 0 & 1 & 0 & 0 & 0 & 1 & 0 & 0 \\
151 & 0 & 0 & 1 & 1 & 0 & 0 & 0 & 0 & 0 & 0 & 0 \\
109 & 0 & 1 & 0 & 0 & 1 & 0 & 0 & 0 & 1 & 0 & 0 \\
9 & 0 & 0 & 0 & 0 & 0 & 0 & 0 & 0 & 1 & 0 & 0 \\
7 & 0 & 1 & 0 & 0 & 0 & 0 & 0 & 0 & 1 & 0 & 0 \\
7 & 0 & 0 & 0 & 0 & 0 & 0 & 0 & 0 & 0 & 0 & 0 \\
1 & 0 & 0 & 0 & 0 & 1 & 0 & 0 & 0 & 0 & 0 & 0 \\
\hline
\end{tabular}

Tabela 3.1: Os sete atratores da rede do ciclo celular da levedura. O valor na primeira coluna indica o tamanho da bacia de atração, seguido dos valores binários de cada gene que compõem o estado atrator.

Biologicamente, o processo do ciclo celular tem início quando existe uma concentração suficiente de Cln3, o que ocorre em condições favoráveis à divisão celular (Alberts et al., 2007). Para simular este processo, eles "estimularam" o estado $\mathrm{G}_{1}$ estacionário (primeira linha da Tabela 3.1) através do sinal do tamanho da célula (cell size), ativando o gene Cln3 (primeira linha da Tabela 3.2). Aplicando a Eq. 2.9 para simular o processo, eles observaram que o sistema volta para 
o estado $\mathrm{G}_{1}$ estacionário. A evolução temporal dos estados, apresentada na Tabela 3.2, segue a sequência do ciclo celular, indo do estado $\mathrm{G}_{1}$ estimulado (Início), passando pelas fases $\mathrm{S}, \mathrm{G}_{2}$ e $\mathrm{M}$, até o estado $\mathrm{G}_{1}$ estacionário. Esta é a via ou trajetória biológica ou via da rede do ciclo celular.

\begin{tabular}{ccccccccccccc}
$t$ & Cln3 & MBF & SBF & Cln1 & Cdh1 & Swi5 & Cdc20 & Clb5 & Sic1 & Clb1 & Mcm1 & Fase \\
\hline 1 & 1 & 0 & 0 & 0 & 1 & 0 & 0 & 0 & 1 & 0 & 0 & Início \\
2 & 0 & 1 & 1 & 0 & 1 & 0 & 0 & 0 & 1 & 0 & 0 & $\mathrm{G}_{1}$ \\
3 & 0 & 1 & 1 & 1 & 1 & 0 & 0 & 0 & 1 & 0 & 0 & $\mathrm{G}_{1}$ \\
4 & 0 & 1 & 1 & 1 & 0 & 0 & 0 & 0 & 0 & 0 & 0 & $\mathrm{G}_{1}$ \\
5 & 0 & 1 & 1 & 1 & 0 & 0 & 0 & 1 & 0 & 0 & 0 & $\mathrm{~S}$ \\
6 & 0 & 1 & 1 & 1 & 0 & 0 & 0 & 1 & 0 & 1 & 1 & $\mathrm{G}_{2}$ \\
7 & 0 & 0 & 0 & 1 & 0 & 0 & 1 & 1 & 0 & 1 & 1 & $\mathrm{M}$ \\
8 & 0 & 0 & 0 & 0 & 0 & 1 & 1 & 0 & 0 & 1 & 1 & $\mathrm{M}$ \\
9 & 0 & 0 & 0 & 0 & 0 & 1 & 1 & 0 & 1 & 1 & 1 & $\mathrm{M}$ \\
10 & 0 & 0 & 0 & 0 & 0 & 1 & 1 & 0 & 1 & 0 & 1 & $\mathrm{M}^{2}$ \\
11 & 0 & 0 & 0 & 0 & 1 & 1 & 1 & 0 & 1 & 0 & 0 & $\mathrm{M}$ \\
12 & 0 & 0 & 0 & 0 & 1 & 1 & 0 & 0 & 1 & 0 & 0 & $\mathrm{G}_{1}$ \\
13 & 0 & 0 & 0 & 0 & 1 & 0 & 0 & 0 & 1 & 0 & 0 & $\mathrm{G}_{1}^{*}$ \\
\hline
\end{tabular}

Tabela 3.2: Evolução temporal dos estados do ciclo celular. A primeira coluna ( $t$ ) indica o tempo, de 1 a 13, para cada estado da via. A última coluna indica a fase do ciclo celular a qual o estado pertence.

A trajetória dos 13 estados da Tabela 3.2 pode ser observada na Fig. 3.3, onde o caminho em negrito indica a via do ciclo celular. Este diagrama de transição de estados contém todos os 1.764 estados que compõem a bacia de atração do atrator $G_{1}$ estacionário.

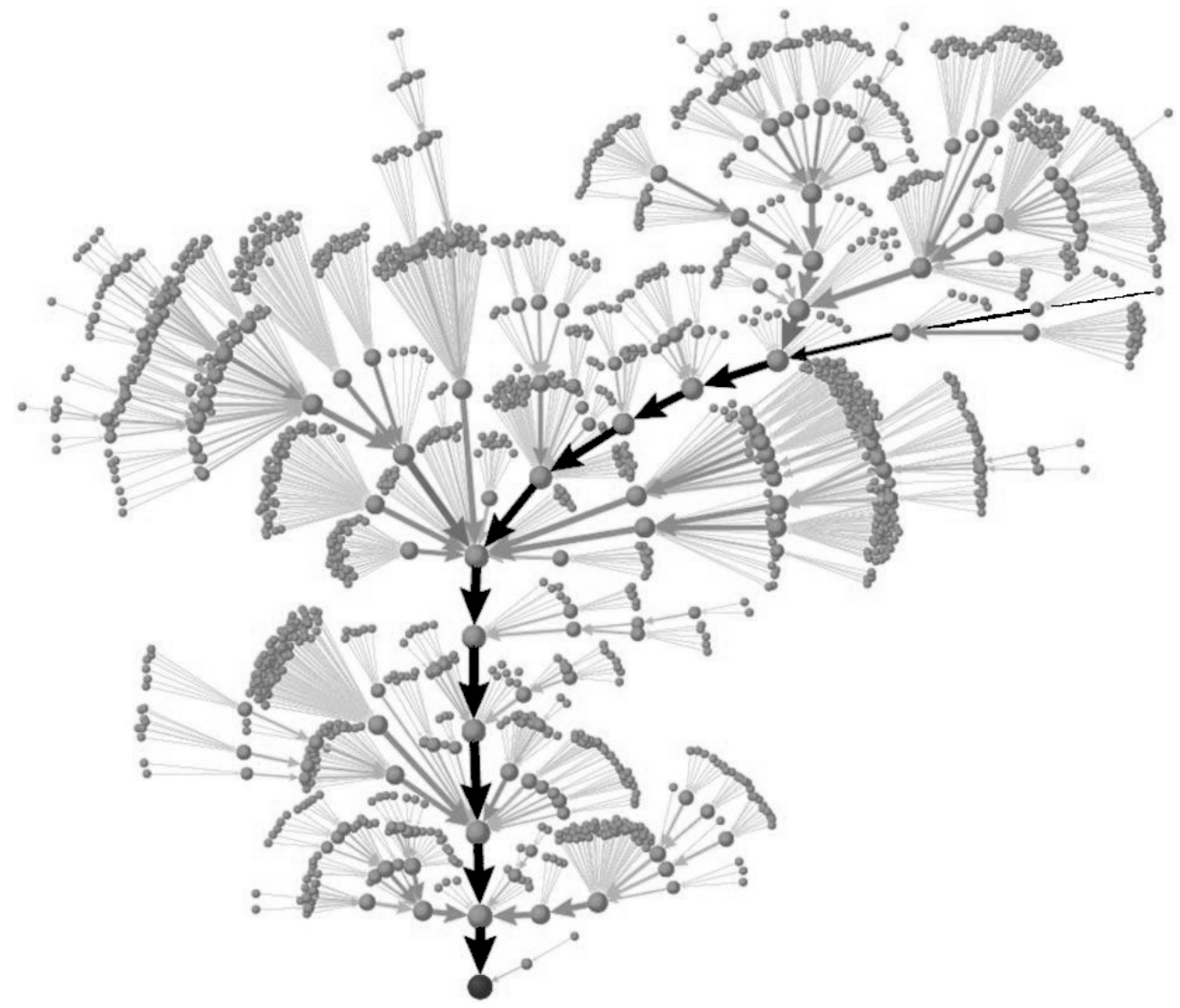

Figura 3.3: A trajetória dos 1.764 estados (nós) em direção ao estado $G_{1}$ estacionário. A via do ciclo celular (Tabela 3.2) é indicada pelo caminho em negrito. Fonte: (Li et al., 2004).

O principal resultado do trabalho de Li et al. (2004) é que esta rede é dinamicamente e estruturalmente estável. Foi mostrado que grande parte da estrutura da bacia de atração na 
Fig. 3.3 é preservada mesmo com pequenas alterações estruturais na rede, e.g., adicionando ou removendo arestas.

Podemos utilizar este modelo para gerar dados de expressão gênica artificiais. Por exemplo, podemos tomar os estados na Tabela 3.1 como um conjunto de dados estacionários, ou a sequência de estados da Tabela 3.2 como uma série temporal de expressão gênica. Assim, podemos aplicar uma metodologia de inferência de GRN nestes dados e verificar as conexões entre os genes que foram recuperadas, comparando a rede inferida com a rede da Fig. 3.2. Este modelo do ciclo celular é determinístico pois, a partir de um determinado estado, aplicando a Eq. 2.9, sempre obteremos o mesmo estado seguinte. Na próxima seção, apresentamos uma versão estocástica deste modelo.

\subsection{Modelo estocástico}

Apesar de interessante, o modelo proposto por Li et al. (2004) não leva em consideração o efeito de ruídos ou perturbações presentes no processo do ciclo celular. O modelo proposto por (Zhang et al., 2006) é um modelo estocástico baseado na rede da Fig. 3.2 com duas pequenas diferenças. A primeira é que a aresta de auto-degradação do Cdc20 é substituída por uma aresta de repressão do Cdh1 para o Cdc20. A segunda é que na matriz de regulação temos $a_{i, j}=-0.1$ no caso de auto-degradação de um gene $x_{i}$. Com esta mudança, a estrutura do diagrama de transição de estados muda levemente, criando dois novos atratores, e portanto, modificando o tamanho da bacia de atração dos atratores já existentes. Os nove atratores são apresentados na Tabela 3.3.

\begin{tabular}{cccccccccccc} 
Tam. bacia & Cln3 & MBF & SBF & Cln1 & Cdh1 & Swi5 & Cdc20 & Clb5 & Sic1 & Clb1 & Mcm1 \\
\hline 1,649 & 0 & 0 & 0 & 0 & 1 & 0 & 0 & 0 & 1 & 0 & 0 \\
$\mathbf{1 3 0}$ & $\mathbf{0}$ & $\mathbf{1}$ & $\mathbf{1}$ & $\mathbf{1}$ & $\mathbf{0}$ & $\mathbf{1}$ & $\mathbf{1}$ & $\mathbf{0}$ & $\mathbf{1}$ & $\mathbf{0}$ & $\mathbf{0}$ \\
106 & 0 & 1 & 0 & 0 & 1 & 0 & 0 & 0 & 1 & 0 & 0 \\
$\mathbf{7 7}$ & $\mathbf{0}$ & $\mathbf{0}$ & $\mathbf{1}$ & $\mathbf{1}$ & $\mathbf{0}$ & $\mathbf{1}$ & $\mathbf{1}$ & $\mathbf{0}$ & $\mathbf{1}$ & $\mathbf{0}$ & $\mathbf{0}$ \\
64 & 0 & 0 & 1 & 1 & 0 & 0 & 0 & 0 & 0 & 0 & 0 \\
9 & 0 & 0 & 0 & 0 & 0 & 0 & 0 & 0 & 1 & 0 & 0 \\
7 & 0 & 0 & 0 & 0 & 0 & 0 & 0 & 0 & 0 & 0 & 0 \\
5 & 0 & 1 & 0 & 0 & 0 & 0 & 0 & 0 & 1 & 0 & 0 \\
1 & 0 & 0 & 0 & 0 & 1 & 0 & 0 & 0 & 0 & 0 & 0 \\
\hline
\end{tabular}

Tabela 3.3: Os nove atratores do modelo proposto por (Zhang et al., 2006). As duas linhas em negrito correspondem aos dois novos atratores.

Neste modelo, a probabilidade de alcançar um estado no próximo instante de tempo depende apenas do estado atual, ou seja, neste modelo estocástico, a evolução da rede possui a propriedade Markoviana (Zhang et al., 2006). Estamos considerando instantes de tempo discreto e assumimos que o processo é homogêneo com relação ao tempo. Assim, a probabilidade de transição da cadeia de Markov é definida por:

$$
\operatorname{Pr}\left[\left(x_{1}(t+1), \ldots, x_{11}(t+1) \mid x_{1}(t), \ldots, x_{11}(t)\right]=\prod_{i=1}^{11} \operatorname{Pr}\left[x_{i}(t+1) \mid x_{1}(t), \ldots, x_{11}(t)\right],\right.
$$

onde 


$$
\begin{gathered}
\operatorname{Pr}\left[x_{i}(t+1)=\lambda_{i} \mid x_{1}(t), \ldots, x_{11}(t)\right]=\frac{\exp \left(\beta\left(2 \lambda_{i}-1\right) \mathcal{I}_{i}(t)\right)}{\exp \left(\beta \mathcal{I}_{i}(t)\right)+\exp \left(-\beta \mathcal{I}_{i}(t)\right)}, \text { se } \mathcal{I}_{i}(t) \neq 0 ; \mathrm{e} \\
\operatorname{Pr}\left[x_{i}(t+1)=x_{i}(t) \mid x_{1}(t), \ldots, x_{11}(t)\right]=\frac{1}{1+e^{-\alpha}}, \text { se } \mathcal{I}_{i}(t)=0
\end{gathered}
$$

onde $\lambda \in\{0,1\}$ e $\mathcal{I}_{i}(t)=\sum_{j=1}^{11} a_{i j} x_{j}(t)$. O parâmetro positivo $\beta$ caracteriza um ruído no sistema relacionado à temperatura. Para caracterizar a estocasticidade quando o input em um gene é zero, o parâmetro $\alpha$ foi introduzido. Note que, quando $\beta, \alpha \rightarrow \infty$, este modelo recupera o comportamento determinístico do modelo proposto por (Li et al., 2004). Este modelo pode ser visto como uma rede Booleana com perturbação, ou seja, cada gene pode ter seu valor alterado aleatoriamente, com uma pequena probabilidade.

Como esta cadeia de Markov possui um número finito de estados e é irredutível, cada estado é acessível por todos os outros estados (não necessariamente em um passo). Nesta cadeia de Markov todos os estados são aperiódicos, uma vez que a probabilidade de transição de um estado para ele mesmo é não nula. Portanto, esta cadeia de Markov é ergódica (Zhang et al., 2006). Neste caso, existe uma distribuição de probabilidade estacionária $\Pi=\left(\pi_{0}, \pi_{1}, \ldots, \pi_{2047}\right)$ que pode ser encontrada solucionando o sistema de equações lineares $\Pi \cdot P=\Pi$, onde $P$ é a matriz de transição de estados da cadeia de Markov.

Para estudar o sistema com relação ao estado biológico $\mathrm{G}_{1}$ estacionário, (Zhang et al., 2006) calcularam a probabilidade estacionária deste estado. Este estado é definido pelo vetor binário (00001000100), que equivale ao número decimal 68. Assim, denotamos esta probabilidade estacionária por $\pi_{68}$ ou $\pi_{\mathrm{G}_{1}}$. No gráfico apresentado na Fig. 3.4 valores de $\pi_{\mathrm{G}_{1}}$ foram calculados em função de $\beta$, para diversos valores de $\alpha$. Para valores altos de $\beta$ (baixa temperatura ou baixo nível de ruído), o estado $\mathrm{G}_{1}$ é o estado mais provável do sistema.

Na Fig. 3.4 ainda é possível notar que para $\alpha=10$ o valor de $\pi_{\mathrm{G}_{1}}$ tende a aumentar para valores de $\beta$ até aproximadamente 3.2 , onde $\pi_{\mathrm{G}_{1}}=0.64$. A partir de então, este valor passa a diminuir até convergir em 0.5 quando $\beta \approx 7$. Para entender este comportamento do sistema, analisamos a matriz de transição de estados da cadeia de Markov. Na verdade, precisamos apenas analisar a linha correspondente ao estado $\mathrm{G}_{1}$ estacionário (linha 68). A maior probabilidade de transição a partir deste estado é a probabilidade de transitar para ele mesmo, ou seja, permanecer no estado $\mathrm{G}_{1}$. Isto acontece pois, considerando o modelo determinístico, este estado é um atrator singleton. Agora, olhando para a segunda maior probabilidade de transição nesta linha, ocorrem empates entre dois ou mais estados. Na Tabela 3.4 podemos ver que para $\alpha=5$ ocorre um empate entre 8 estados, para $\beta=3$ e $\beta=7$. Quando $\alpha=10$, podemos ver que, para $\beta=3$, a segunda maior probabilidade de transição não corresponde aos mesmos estados para $\beta=7$. Além disso, os estados 4, 64 e 580 são estados atratores. Dessa maneira, quando simulamos o sistema com $\alpha=10$ e $\beta=7$, eventualmente ocorre uma transição do estado $\mathrm{G}_{1}$ estacionário para um destes estados atratores, onde o sistema permanece por um certo tempo. Isso se reflete no valor de $\pi_{\mathrm{G}_{1}}$, que possui um valor menor quando $\beta=7$, se comparado com $\beta=3$ (para $\alpha=10$ ).

Outros trabalhos estendidos a partir do modelo de (Li et al., 2004) e (Zhang et al., 2006) 


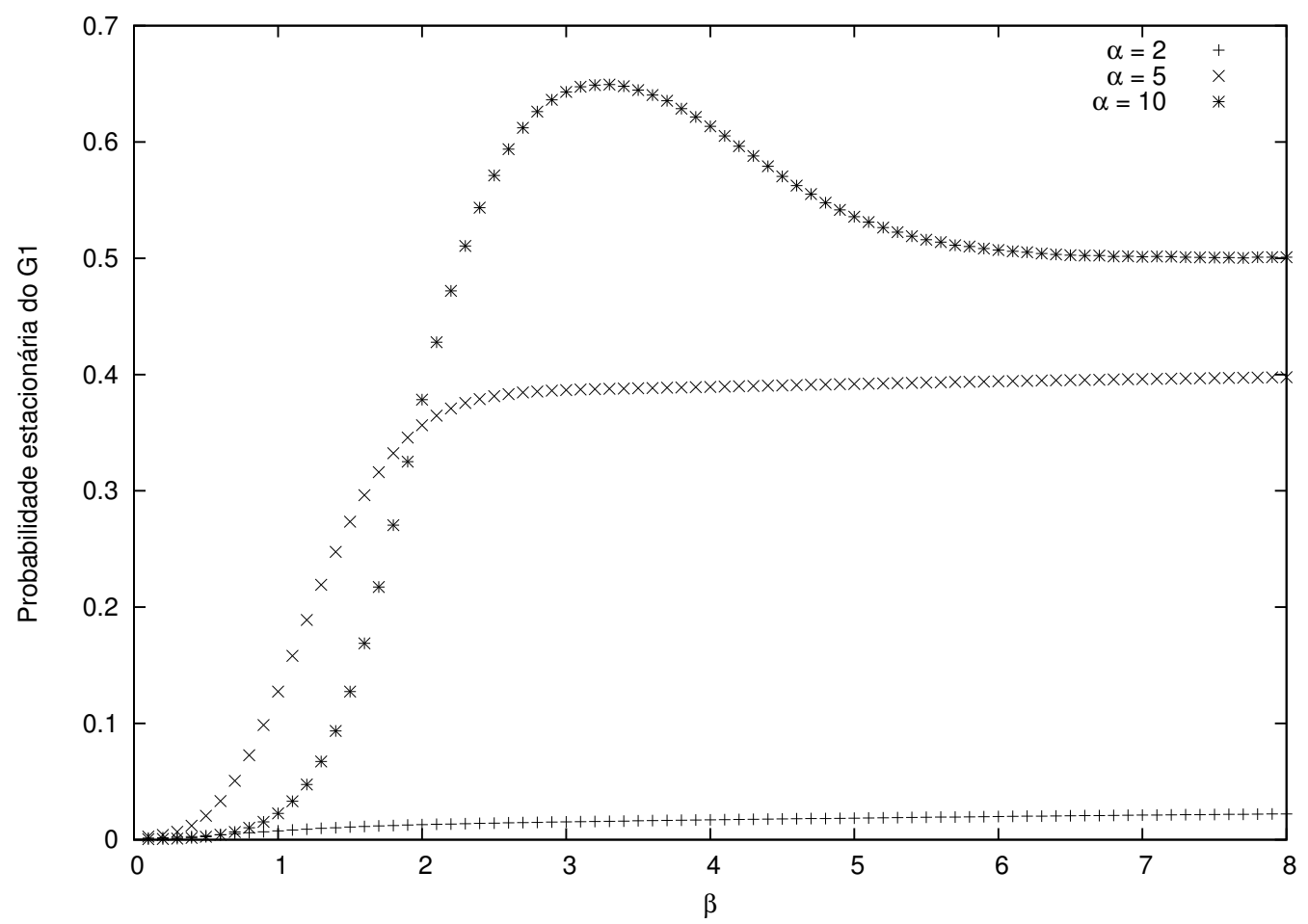

Figura 3.4: Gráfico mostrando a probabilidade estacionária do estado $G_{1}^{*}$.

\begin{tabular}{|c|c|l|}
\hline$\alpha$ & $\beta$ & Estados com a segunda maior prob. de transição \\
\hline \hline \multirow{2}{*}{5} & 3 & $4,64,69,100,196,324,580$ e 1092 \\
\cline { 2 - 3 } & 7 & $4,64,69,100,196,324,580$ e 1092 \\
\hline \hline \multirow{2}{*}{10} & 3 & 76 e 84 \\
\cline { 2 - 3 } & 7 & $4,64,69,100,196,324,580$ e 1092 \\
\hline
\end{tabular}

Tabela 3.4: Estados com a segunda maior probabilidade de transição a partir do estado $G_{1}$ estacionário. Os estados estão representados pelo valor em decimal do correspondente vetor binário. Para $\alpha=5$ a estrutura da matriz de transição se mantém quando passamos de $\beta=3$ para $\beta=7$. O mesmo não acontece para $\alpha=10$.

podem ser encontrados na literatura. Por exemplo, em (Braunewell e Bornholdt, 2007) o modelo determinístico foi estendido, adicionando-se ruído e permitindo a atualização assíncrona dos genes. Foi mostrado que o modelo se mantém robusto mesmo levando em consideração a assincronia na ativação/degradação de proteínas no sistema biológico. Em (Irons, 2009), o modelo de (Li et al., 2004) também foi estendido permitindo um atraso na atualização dos genes. Além disso, outros genes foram adicionados e as funções Booleanas foram escolhidas levando-se em consideração informações disponíveis na literatura. 


\section{Capítulo 4}

\section{Modelagem do ciclo celular}

Neste capítulo, iremos apresentar um modelo para o ciclo celular da levedura baseado no modelo proposto por (Zhang et al., 2006). Como apresentado no Capítulo 3, o modelo estocástico de (Zhang et al., 2006) pode ser visto como uma cadeia de Markov ergódica homogênea. A nossa proposta de modelagem consiste em utilizar uma cadeia de Markov não homogênea, em que a matriz de transição de estados pode variar com o passar do tempo. Iremos nos referir ao nosso modelo por NHMC (nonhomogeneous Markov chain).

O modelo NHMC originou-se a partir de uma modelagem utilizando redes Booleanas probabilísticas sensíveis ao contexto, cPBN (Higa et al., 2009b), que apresentaremos também neste capítulo. O objetivo foi propor uma extensão dos modelos existentes. No modelo de (Zhang et al., 2006), uma vez que o sistema se encontra no estado atrator $\mathrm{G}_{1}$ estacionário, a probabilidade de que o sistema percorra novamente os estados do ciclo celular é muito pequena. No modelo que propomos, a saída do estado $G_{1}$ estacionário para que uma nova divisão celular ocorra é modelada explicitamente. Comparamos os modelos em termos de distribuição de probabilidade estacionária. Para o nosso modelo, primeiramente estimamos, e depois, propomos uma maneira para calcular analiticamente esta distribuição.

Na próxima seção, apresentaremos o modelo cPBN, que é um modelo simples e que serviu como base para o modelo NHMC, apresentado na Seção 4.2.

\subsection{Modelo cPBN}

De acordo com o modelo de (Zhang et al., 2006), uma vez que a célula encontra-se no estado $\mathrm{G}_{1}$ estacionário, ela permanecerá neste estado a menos que um ruído ocorra. Além disso, a probabilidade de que a célula saia deste estado diminui quando $\alpha, \beta \rightarrow \infty$, ou seja, quando este modelo tende ao modelo determinístico de (Li et al., 2004). Sendo assim, a transição do estado $\mathrm{G}_{1}$ estacionário para o estado que representa o início do ciclo celular (veja Tabela 3.2) não é modelado explicitamente, o que significa que, neste modelo, uma vez que a célula se divide e entra novamente no estado $\mathrm{G}_{1}$ estacionário, ela dificilmente passará por uma nova etapa de divisão celular. Para modelar esta transição, nós propomos um modelo baseado em redes Booleanas probabilísticas sensíveis ao contexto, que chamamos aqui de modelo cPBN.

Uma rede Booleana probabilística (PBN) é formada por um conjunto de redes Booleanas 
(BNs), e a cada passo no tempo uma BN é escolhida para governar a transição de estados. $\mathrm{O}$ modelo de redes Booleanas sensíveis ao contexto (cPBN) limita esta troca de BNs, onde uma $\mathrm{BN}$ permanece governando a transição de estados por um certo tempo, até que algum evento aleatório ocorra, por exemplo, correspondendo a algum estímulo externo à célula. Quando isso ocorre, dizemos que houve uma troca de contexto na célula, e uma outra BN passa a governar a transição de estados. Além disso, é possível adicionar a perturbação, utilizando um conjunto de redes Booleanas com perturbação (BNps) ao invés de BNs. O nosso modelo é baseado no modelo cPBN, apesar de que existe uma diferença com relação à definição original. A troca de contexto de uma BN para outra é realizada de forma determinística e em uma determinada condição, como veremos mais adiante.

Como vimos na Seção 3.2, a trajetória biológica do ciclo celular é composta por 13 estados. Vamos denotar estes estados por $e_{1}, e_{2}, \ldots, e_{13}$, onde $e_{1}$ e $e_{13}$ correspondem à primeira e à última linha da Tabela 3.2, respectivamente. O primeiro modelo cPBN que propomos em (Higa e Hashimoto, 2007) consiste de duas BNps, $B_{1}$ e $B_{2}$ (Fig. 4.1). A $B_{1}$ é essencialmente o modelo Booleano proposto por ( $\mathrm{Li}$ et al., 2004), incluindo uma probabilidade de perturbação $p$. Na $B_{1}$, existe uma alta probabilidade de que ocorra a transição $e_{13} \rightarrow e_{13}$ (atrator singleton). $\mathrm{Na} B_{2}$, a transição $e_{13} \rightarrow e_{13}$ é substituída pela transição $e_{13} \rightarrow e_{1}$, fazendo com que a célula passe por uma nova etapa de divisão celular. Esta mudança, de $B_{1}$ para $B_{2}$, caracteriza a troca de contexto, controlada por um parâmetro $T$, que indica a quantidade de transições $e_{13} \rightarrow e_{13}$ necessárias para que a célula inicie uma nova etapa do ciclo. $T$ pode ser visto como o tempo necessário para que a célula cresça e inicie o processo de divisão celular. Assim, temos duas trocas de contexto determinísticas: $(i)$ a primeira quando a variável $T$ (um contador, inicializado com 0 e incrementado a cada transição $e_{13} \rightarrow e_{13}$ ) atinge um certo valor positivo, fazendo o sistema trocar de contexto, de $B_{1}$ para $B_{2}$; (ii) uma vez que a transição $e_{13} \rightarrow e_{1}$ ocorre, há uma nova troca de contexto, de $B_{2}$ para $B_{1}$.

Na Fig. 4.2 apresentamos um gráfico com o valor da probabilidade estacionária $\pi_{G_{1}}$ em função do parâmetro $p$, para $T=10,20$ e 30. Estas probabilidades foram calculadas através de simulações do sistema. Como esperado, esta probabilidade diminui a medida que o valor da probabilidade de perturbação $p$ aumenta, pois o sistema se torna mais instável. A partir de $p \approx 0.03$ é possível ver que os valores de $T$ não são mais significantes, pois existe uma alta probabilidade de que ocorra uma perturbação antes que $T$ transições $e_{13} \rightarrow e_{13}$ ocorram.

Na Fig. 4.3 comparamos o modelo cPBN com o modelo de (Zhang et al., 2006), com relação à probabilidade estacionária dos demais estados da via do ciclo celular. Os parâmetros de ambos os modelos foram escolhidos de forma que a probabilidade estacionária do estado $\mathrm{G}_{1}$ dos dois modelos fossem muito próximas. Podemos notar que no modelo cPBN a probabilidade dos estados da via do ciclo celular aumenta levemente, pois neste modelo existe uma maior probabilidade de que a célula passe por uma nova divisão celular.

\subsection{Modelo NHMC}

O modelo NHMC é uma extensão do modelo cPBN (Higa et al., 2009b). Este modelo consiste de $\gamma$ matrizes de transição de estados, ou seja, $\gamma$ cadeias de Markov ergódicas $P_{1}, P_{2}, \ldots, P_{\gamma}$. Em 


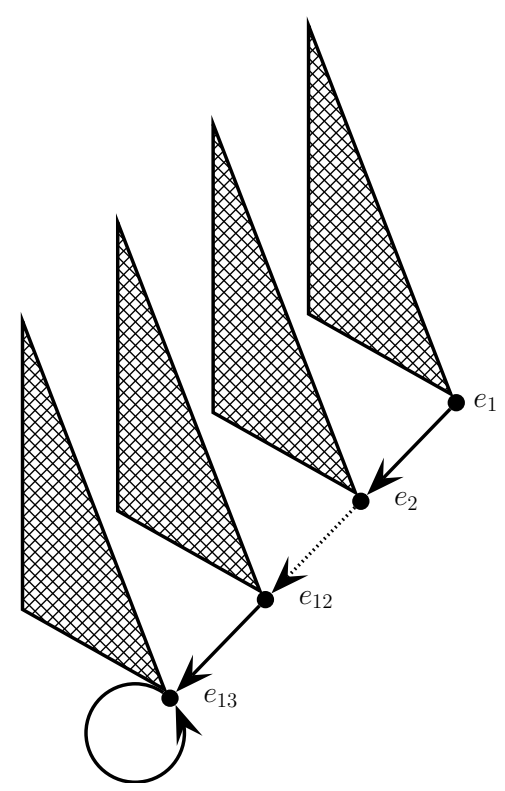

(a) $B_{1}$

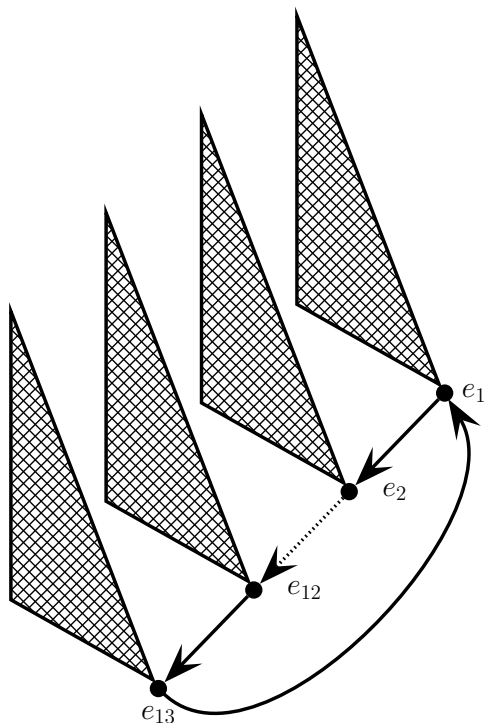

(b) $B_{2}$

Figura 4.1: Esquema gráfico denotando os diagramas de transição de estados das BNps $B_{1}$ e $B_{2}$. $O$ triângulo hachurado ligado a um estado $e_{i}$ indica o conjunto de estados que convergem para este estado. $A$ diferença entre as redes é que na rede $B_{1}$, a transição mais provável a partir do estado $e_{13}$ é $e_{13} \rightarrow e_{13}$, enquanto que na rede $B_{2}$ é a transição $e_{13} \rightarrow e_{1}$.

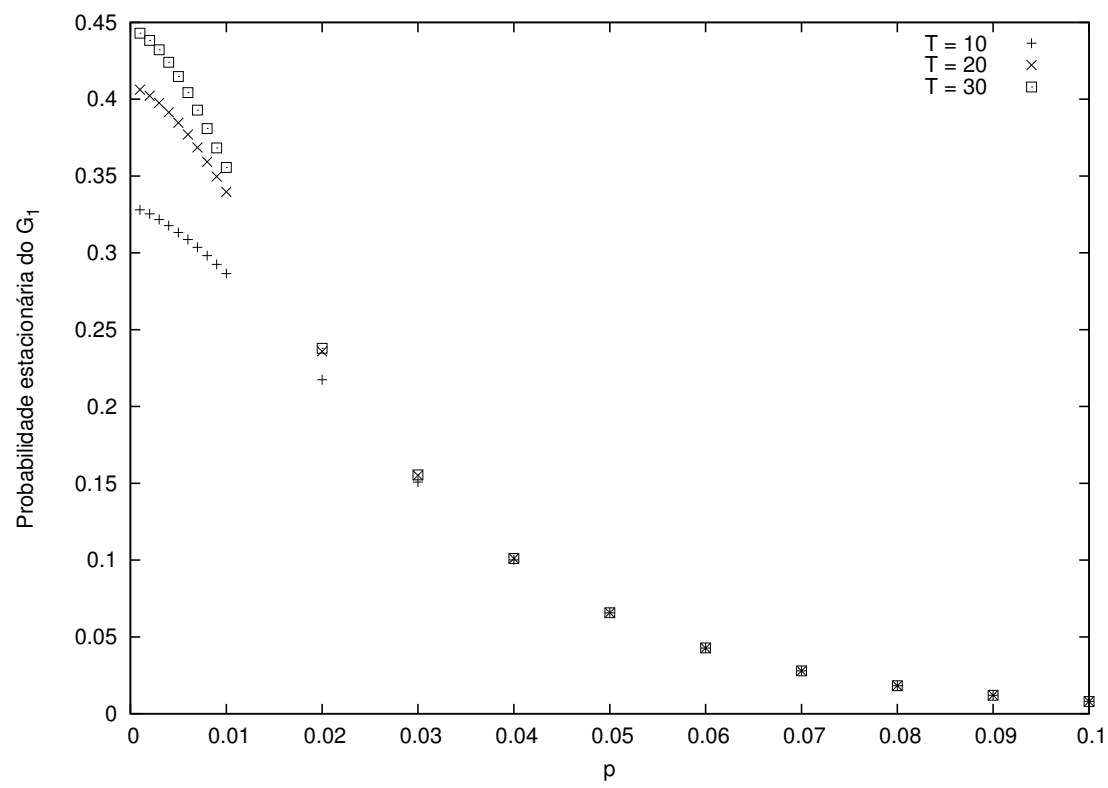

Figura 4.2: Gráfico mostrando a probabilidade estacionária do estado $G_{1}$ em função da probabilidade de perturbação p, para $T=10,20$ e 30 .

cada matriz $P_{k}, k=1,2, \ldots, \gamma$, a posição $p_{a, b}^{(k)}$ é a probabilidade de transição de $e_{a}$ para $e_{b}$. A primeira matriz, $P_{1}$ é a matriz obtida através do modelo de (Zhang et al., 2006) para um certo par de parâmetros $\alpha$ e $\beta$. A última matriz, $P_{\gamma}$ é a matriz $P_{1}$ com as posições $p_{13,1}^{(1)}$ e $p_{13,13}^{(1)}$ trocadas. Dessa maneira, em $P_{\gamma}$ damos mais massa de probabilidade para a transição $e_{13} \rightarrow e_{1}$, como na Fig. 4.1b. Formalmente, a $k$-ésima matriz de transição é obtida a partir das seguintes 


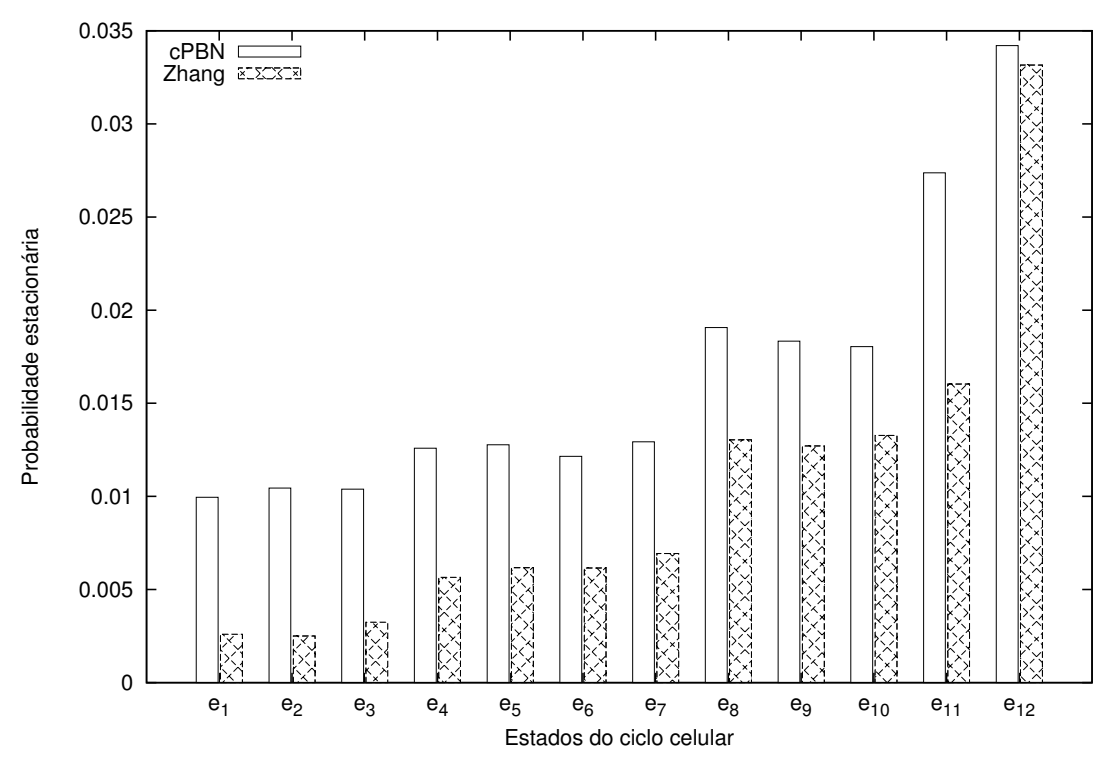

Figura 4.3: Gráfico comparando a probabilidade estacionária dos estados da via do ciclo celular.

equações:

$$
\begin{aligned}
& p_{13,1}^{(k)}=(1-g(k)) \cdot p_{13,1}^{(1)}+g(k) \cdot p_{13,13}^{(1)} \\
& p_{13,13}^{(k)}=(1-g(k)) \cdot p_{13,13}^{(1)}+g(k) \cdot p_{13,1}^{(1)} \\
& p_{i, j}^{(k)}=p_{i, j}^{(1)}, \text { para } i \neq 13 \text { ou }(j \neq 13 \text { e } j \neq 1),
\end{aligned}
$$

onde $g(k):\{1, \ldots, \gamma\} \rightarrow[0,1]$ tal que $g(1)=0, g(\gamma)=1$ e $g(k-1) \leq g(k)$, para $k=2,3, \ldots, \gamma$. Existem várias opções para a escolha de $g(\cdot)$; nós optamos por uma mudança linear entre as matrizes, ou seja,

$$
g(k)=\frac{k-1}{\gamma-1} .
$$

O processo de ciclo celular é modelado da seguinte maneira: inicialmente, o processo segue as transições de acordo com a matriz $P_{1}$ até que o sistema atinja o estado $\mathrm{G}_{1}$ estacionário, $e_{13}$, onde a célula permanece até que haja condições favoráveis para uma nova divisão celular (por exemplo, até que haja uma concentração suficiente da proteína $C \ln 3$, que desencadeia o início da divisão celular). A cada transição $e_{13} \rightarrow e_{13}$, a matriz de transição $P_{k}$ é substituída pela matriz $P_{k+1}$, até que $k=\gamma-1$. Note que, se uma ocorrer uma transição que não seja $e_{13} \rightarrow e_{13}$ ou $e_{13} \rightarrow e_{1}$, não ocorre a substituição da matriz. Eventualmente, a transição $e_{13} \rightarrow e_{1}$ irá ocorrer, quando a célula inicia o processo de divisão, e então a matriz $P_{1}$ passa a governar as transições entre estados.

Este modelo baseado em redes Booleanas sensíveis ao contexto é diferente da definição original (Seção 2.3.4), pois a troca de contexto está condicionada à transição $e_{13} \rightarrow e_{13}$, que representa a fase $\mathrm{G}_{1}$ estacionária. $\mathrm{O}$ número de matrizes $\gamma$ é um parâmetro do nosso modelo e, quando $\gamma \rightarrow \infty$, o modelo tende ao modelo estocástico de (Zhang et al., 2006). Note que, apesar do modelo constituir uma cadeia de Markov heterogênea, a cadeia continua ergódica, uma vez que cada matriz do modelo corresponde a uma cadeia de Markov ergódica. 
Para comparar o nosso modelo com o modelo de Zhang, realizamos três experimentos. Para isso, a distribuição de probabilidade estacionária do nosso modelo foi obtida (estimada) através de simulações do sistema, $\operatorname{com} \gamma=13$. No primeiro experimento, estudamos a probabilidade estacionária do sistema se encontrar no estado $\mathrm{G}_{1}$ estacionário em função do parâmetro $\beta$. Em ambos os modelos, a maior massa de probabilidade encontra-se no estado $\mathrm{G}_{1}$. Na Fig. 4.4 podemos ver que para valores mais altos de $\beta$ (baixa temperatura ou baixo nível de ruído) esta probabilidade é maior no modelo de Zhang (para $\alpha=5$ fixo). Isso ocorre pois no modelo de Zhang o sistema passa mais tempo no estado $e_{13}$ (devido à transição $e_{13} \rightarrow e_{13}$ ). No entanto, o comportamento em ambos os modelos é o mesmo: $\pi_{\mathrm{G}_{1}}$ aumenta a medida em que $\beta$ aumenta e, segundo (Zhang et al., 2006), existe uma fase de transição por volta de $\beta=1.0$ onde o sistema se torna instável para níveis mais altos de ruídos (menores valores de $\beta$ ). Quando o nível de ruído fica abaixo desse ponto, o sistema se torna ordenado; a via do ciclo celular se torna a via mais provável, e a probabilidade de desvio desta via se torna pequena.

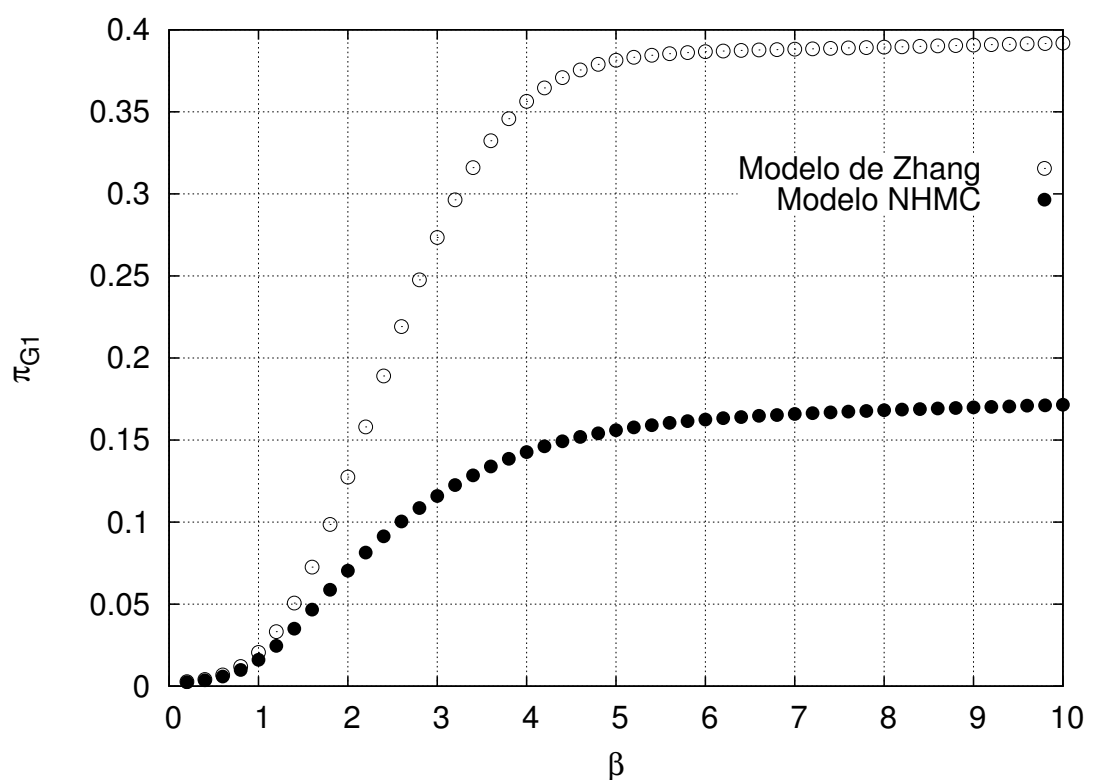

Figura 4.4: Probabilidade estacionária do estado $G_{1}$ em função de $\beta$, com $\alpha=5$. Para o modelo NHMC, usamos $\gamma=13$.

Em um segundo experimento, analisamos a probabilidade estacionária dos estados da via do ciclo celular, $e_{1}, \ldots, e_{13}$. Para este experimento, definimos $\alpha=5$ e $\beta=6$. Segundo (Zhang et al., 2006), nesta situação o sistema é considerado estável. Na Fig. 4.5 comparamos a probabilidade estacionária dos estados da via do ciclo celular do nosso modelo com o modelo de Zhang. Podemos ver que, exceto para o estado $e_{13}$, o nosso modelo apresenta uma probabilidade um pouco mais alta. Isto acontece pois no nosso modelo, a probabilidade de ocorrer a transição $e_{13} \rightarrow e_{1}$ aumenta quando a transição $e_{13} \rightarrow e_{13}$ ocorre. Assim, modelamos explicitamente a transição $e_{13} \rightarrow e_{1}$, dando início a uma nova divisão celular.

Em um terceiro experimento, analisamos o fluxo de rede entre os estados consecutivos da via do ciclo celular. Em (Zhang et al., 2006), o fluxo de rede entre dois estados, $e_{i}$ e $e_{j}$, é definido 


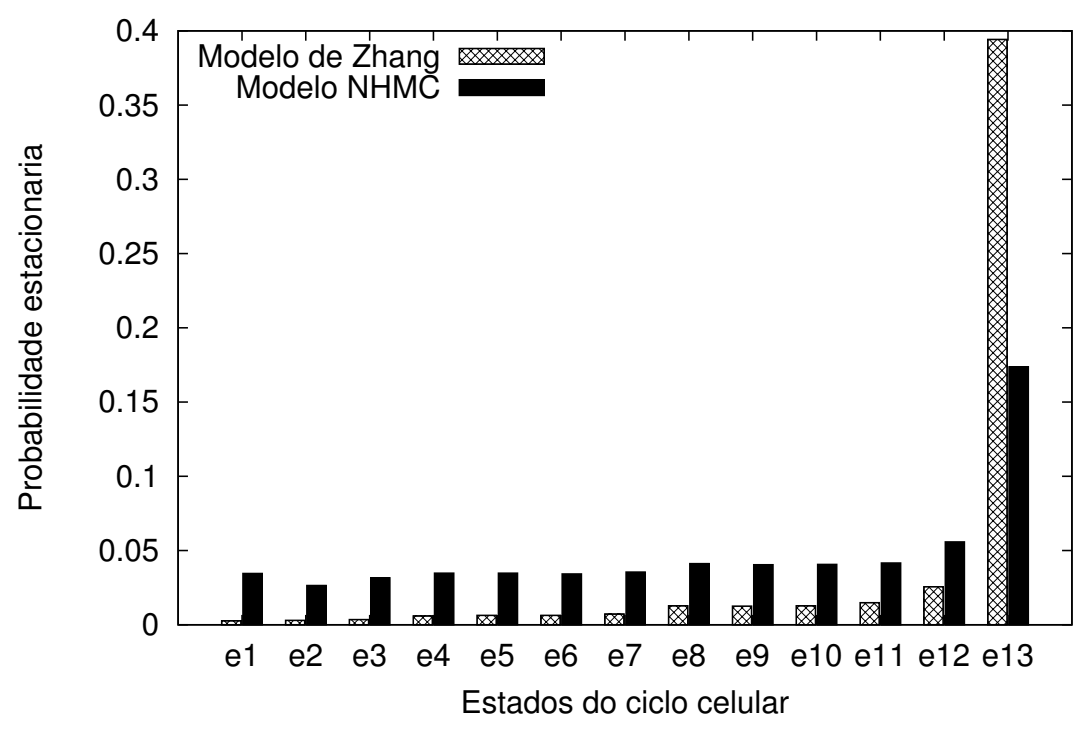

Figura 4.5: Probabilidade estacionária dos estados da via do ciclo celular.

por

$$
\pi_{i} \cdot p_{i, j}-\pi_{j} \cdot p_{j, i}
$$

onde $p_{i, j}$ é a probabilidade de transição de $e_{i}$ para $e_{j}$. A probabilidade $\pi_{i} \cdot p_{i, j}$ pode ser intuitivamente interpretada como a taxa de transição (ou probabilidade de fluxo) de $e_{i}$ para $e_{j}$ (Ross, 2007). No modelo NHMC, os valores de $p_{i, j}^{(k)}, k=1, \ldots, \gamma$, são iguais a $p_{i, j}$ do modelo de Zhang, exceto $p_{1,13}^{(k)}$ e $p_{13,1}^{(k)}$. No nosso modelo, estimamos estas duas últimas probabilidades através de simulações. De acordo com (Zhang et al., 2006), o fluxo entre diferentes estados do sistema é predominante entre os estados da via do ciclo celular. Isto também ocorre no nosso modelo, conforme a Fig. 4.6. Além disso, podemos ver que o fluxo entre os estados da via é maior no modelo NHMC.

\subsubsection{Calculando $\Pi$ analiticamente}

O próximo passo foi calcular a distribuição estacionária analiticamente. Para isso, fizemos algumas modificações no modelo cPBN. Primeiro, modelamos o parâmetro $\alpha$ em função de $\beta$, ou seja, $\alpha=f(\beta)$. Explicaremos mais adiante o motivo desta mudança. A segunda modificação foi considerar as matrizes $P_{1}, P_{2}, \ldots, P_{\gamma}$ como uma única matriz $P$ de dimensão $\left(2^{n} \cdot \gamma\right) \times\left(2^{n} \cdot \gamma\right)$, onde $n=11$ genes. Em outras palavras, $P$ é formada pelas submatrizes $P_{1}, P_{2}, \ldots, P_{\gamma}$ na diagonal principal de $P$. Assim, podemos ver o modelo cPBN como uma cadeia de Markov onde os estados são $s_{0}^{1}, \ldots, s_{2047}^{1}, s_{0}^{2}, \ldots, s_{2047}^{\gamma}$. Portanto, $s_{i}^{k}$ denota o estado $s_{i}$ da submatriz $P_{k}$

O estado $\mathrm{G}_{1}$ estacionário, $e_{13}$, corresponde ao vetor binário que representa o número decimal 68 (última linha da Tabela 3.2). Assim, indicaremos este estado por $s_{68}^{k}$ quando nos referirmos a este estado na submatriz $P_{k}$. Analogamente, o primeiro estado do ciclo, $e_{1}$, é denotado por $s_{1092}^{k}$. Para modelar o processo do ciclo celular, apenas as seguintes transições são permitidas: 


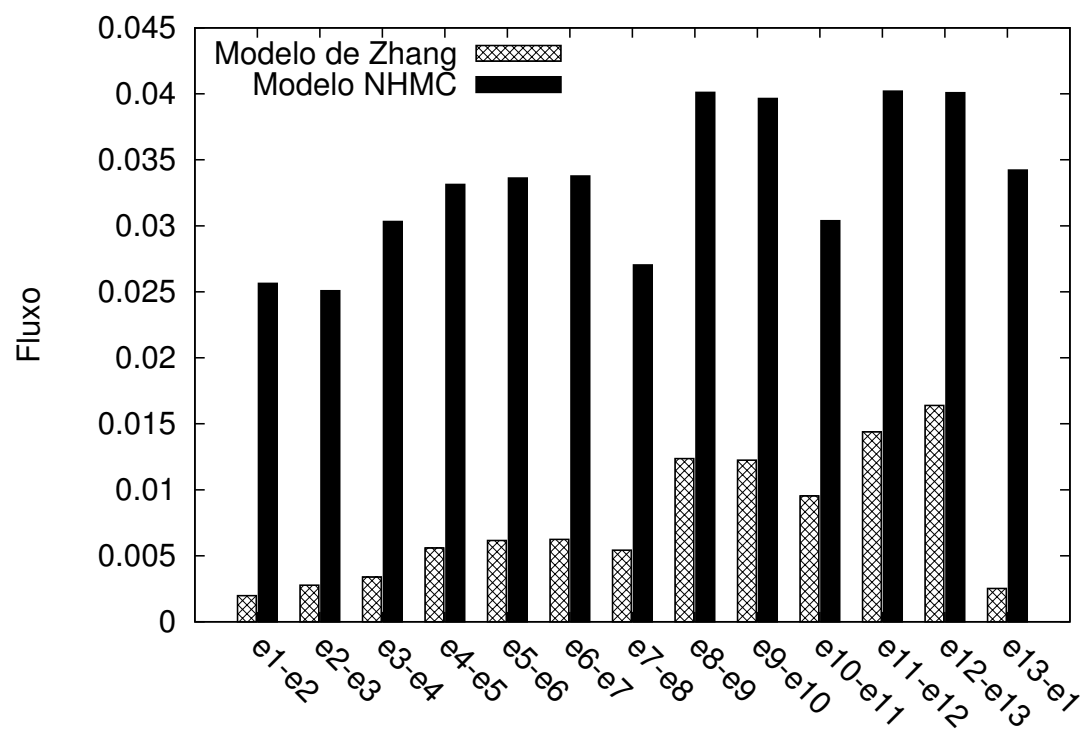

Figura 4.6: Fluxo entre os estados consecutivos da via do ciclo celular.

- $s_{i}^{k} \rightarrow s_{j}^{k}, i \neq 68$, para $k=1, \ldots, \gamma$;

- $s_{68}^{k} \rightarrow s_{j}^{k}, j \neq 68,1092$, para $k=1, \ldots, \gamma$;

- $s_{68}^{k} \rightarrow s_{68}^{k+1}$, para $k=1, \ldots, \gamma-1$;

- $s_{68}^{k} \rightarrow s_{1092}^{1}$, para $k=1, \ldots, \gamma$.

As demais transições não são permitidas, e para isso são colocados valores nulos em $P$. Para ilustrar como construímos esta matriz $P$, vamos considerar um exemplo onde $\gamma=3$. Assim, temos três submatrizes $P_{1}, P_{2}$ e $P_{3}$ formando a matriz $P$, onde os $3 \cdot 2^{11}$ estados são $s_{0}^{1}, \ldots, s_{2047}^{3}$. Em $P$, denotaremos a probabilidade de transição de $s_{i}^{k}$ para $s_{j}^{k^{\prime}}$ por $\mathrm{P}\left[s_{i}^{k} \rightarrow s_{j}^{k^{\prime}}\right]$. Na Fig. 4.7 mostramos a matriz $P$ formada pelas três submatrizes. As áreas hachuradas indicam valores nulos na matriz. Como a transição $s_{68}^{1} \rightarrow s_{68}^{1}$ não é permitida temos $\mathrm{P}\left[s_{68}^{1} \rightarrow s_{68}^{1}\right]=0$. Porém, a partir do estado $s_{68}^{1}$ é possível transitar para o estado $s_{68}^{2}$. Dessa maneira, construímos a matriz $P$ definindo $\mathrm{P}\left[s_{68}^{1} \rightarrow s_{68}^{2}\right]=p_{68,68}^{(1)}$, indicado por uma flecha na Fig. 4.7 .

Com esta matriz $P$, quando um estado $s_{68}^{k}$ é alcançado, a transição $s_{68}^{k} \rightarrow s_{68}^{k+1}$ pode ocorrer, e o próximo passo será governado pela submatriz $P_{k+1}$. Se em algum momento ocorrer a transição $s_{68}^{k} \rightarrow s_{1092}^{1}$, significa que a célula passou do estado $\mathrm{G}_{1}$ estacionário para o primeiro estado da via do ciclo celular. Assim, a submatriz $P_{1}$ será utilizada no próximo passo. Nas demais transições $s_{i}^{k} \rightarrow s_{j}^{k}$, a submatriz $P_{k}$ continua governando as transições seguintes.

Para calcular a distribuição estacionária $\Pi=\left(\pi_{0}^{1}, \ldots, \pi_{2047}^{\gamma}\right)$ devemos solucionar o sistema de equações lineares

$$
\Pi^{T} \cdot P=\Pi^{T} .
$$

Se considerarmos o conjunto de estados $\left\{s_{i}^{1}, s_{i}^{2}, \ldots, s_{i}^{\gamma}\right\}, i=0, \ldots, 2047$, como sendo um super 


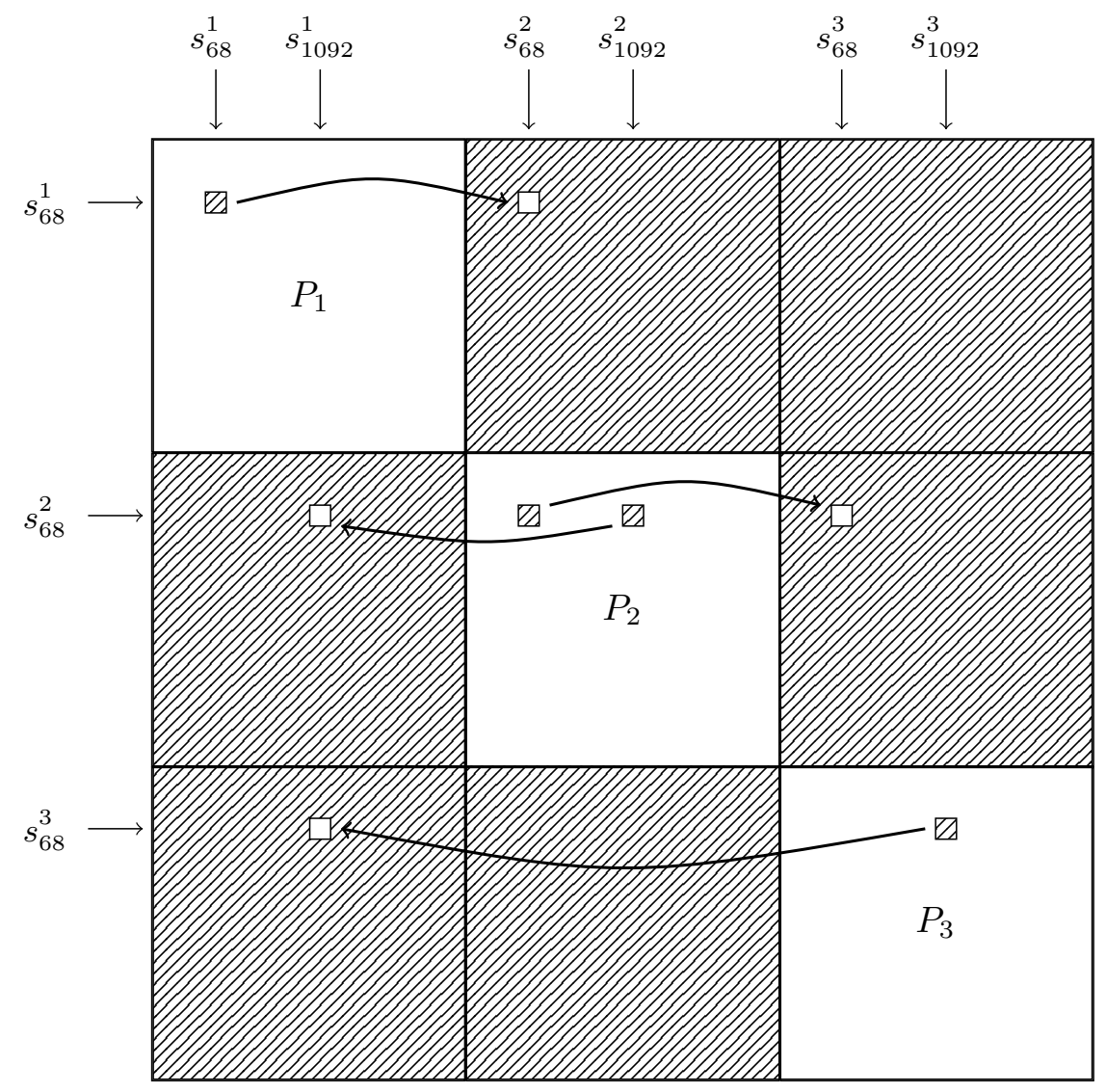

Figura 4.7: Matriz $P$ composta pelas submatrizes $P_{1}, P_{2}$ e $P_{3}$. Áreas hachuradas indicam valores nulos. Uma flecha de uma posição $p_{i, j}$ para uma posição $p_{i, k}$ indica que o valor de $p_{i, j}$ foi atribuido a $p_{i, k}$, e em seguida, foi atribuido o valor 0 a $p_{i, j}$.

estado $s_{i}$, definimos sua probabilidade estacionária por

$$
\pi_{i}=\sum_{k=1}^{\gamma} \pi_{i}^{k} .
$$

Para encontrar uma solução para o sistema linear da Eq. 4.4, procedemos da seguinte maneira. A matriz $P$ é dada por

$$
P=\left(\begin{array}{ccccccc}
P_{1}^{\prime} & Q_{1} & O & O & \cdots & O & O \\
R_{2} & P_{2}^{\prime} & Q_{2} & O & \cdots & O & O \\
R_{3} & O & P_{3}^{\prime} & Q_{3} & \cdots & O & O \\
\vdots & \vdots & \vdots & \vdots & \ddots & \vdots & \vdots \\
R_{\gamma-1} & O & O & O & \cdots & P_{\gamma-1}^{\prime} & Q_{\gamma-1} \\
R_{\gamma} & O & O & O & \cdots & O & P_{\gamma}^{\prime}
\end{array}\right)
$$

onde as submatrizes $P^{\prime}, Q, R$ e $O$, de dimensão $2^{11} \times 2^{11}$, são definidas como segue:

- $Q_{i}, i=1, \ldots, \gamma-1: q_{68,68}^{(i)}=p_{68,68}^{(i)}$ e todas as outras posições são configuradas com zero;

- $R_{i}, i=2, \ldots, \gamma: r_{68,1092}^{(i)}=p_{68,1092}^{(i)}$ e todas as outras posições são configuradas com zero;

- $P_{1}^{\prime}$ : é a matriz $P_{1}$ com a posição $p_{68,68}^{(1)}$ configurada com zero; 
- $P_{\gamma}^{\prime}$ : é a matriz $P_{\gamma}$ com a posição $p_{68,1092}^{(\gamma)}$ configurada com zero;

- $P_{i}^{\prime}, i=2, \ldots, \gamma-1$ : é a matriz $P_{i}$ com ambas as posições $p_{68,68}^{(i)}$ e $p_{68,1092}^{(i)}$ configuradas com zero;

- $O$ : é a matriz nula.

Para calcular a distribuição estacionária, devemos encontrar o vetor $\Pi^{T}=\left(\pi_{0}^{1}, \ldots, \pi_{2047}^{\gamma}\right)$ tal que

$$
\Pi^{T} P=\Pi^{T} \Leftrightarrow\left(P^{T}-I\right) \Pi=\mathbf{0} .
$$

A matriz $\bar{P}=\left(P^{T}-I\right)$ é dada por:

$$
\bar{P}=\left(\begin{array}{ccccccc}
\left(P_{1}^{\prime}-I\right)^{T} & R_{2}^{T} & R_{3}^{T} & R_{4}^{T} & \cdots & R_{\gamma-1}^{T} & R_{\gamma}^{T} \\
Q_{1}^{T} & \left(P_{2}^{\prime}-I\right)^{T} & Q_{2} & O & \cdots & O & O \\
O & Q_{2}^{T} & \left(P_{3}^{\prime}-I\right)^{T} & Q_{3} & \cdots & O & O \\
\vdots & \vdots & \vdots & \vdots & \ddots & \vdots & \vdots \\
O & O & O & O & \cdots & \left(P_{\gamma-1}^{\prime}-I\right)^{T} & O \\
O & O & O & O & \cdots & Q_{\gamma-1}^{T} & \left(P_{\gamma}^{\prime}-I\right)^{T}
\end{array}\right) .
$$

Assim, precisamos encontrar um vetor $\Pi \in \operatorname{Ker}(\bar{P})$ e normalizá-lo, para que a soma de seus componentes seja igual a 1. Neste caso, como se trata de uma cadeia de Markov ergódica, sabemos que existe uma única distribuição estacionária П. Assim, se atribuirmos a qualquer componente de $\Pi$ um valor pré-definido, e.g., $\pi_{0}^{1}=1$, e excluir uma das equações, teremos um sistema linear possuindo uma única solução que podemos resolver para encontrar os valores de $\pi_{1}^{1}, \pi_{2}^{1}, \ldots, \pi_{2047}^{\gamma}$.

Excluindo qualquer equação, ainda teríamos que solucionar um sistema $\left(2^{11} \gamma-1\right) \times\left(2^{11} \gamma-1\right)$; mas se excluirmos a equação correspondente a 1092-ésima linha de $\bar{P}$, as matrizes $R_{k}^{T}$ irão se tornar matrizes nulas, facilitando a resolução do sistema. Dessa maneira, atribuindo $\pi_{0}^{1}=1$, teremos o seguinte sistema de equações:

$$
\left(\begin{array}{cccccc}
\hline\left(P_{1}^{\prime}-I\right)^{T} & 0 & 0 & \cdots & 0 & 0 \\
Q_{1}^{T} & \left(P_{2}^{\prime}-I\right)^{T} & 0 & \cdots & 0 & 0 \\
0 & Q_{2}^{T} & P_{3}^{\prime}-I^{T} & \ldots & 0 & 0 \\
\vdots & \vdots & \vdots & \ddots & \vdots & \vdots \\
0 & 0 & 0 & \ldots & \left(P_{\gamma-1}^{\prime}-I\right)^{T} & 0 \\
0 & 0 & 0 & \ldots & Q_{\gamma-1}^{T} & \left(P_{\gamma}^{\prime}-I\right)^{T}
\end{array}\right) \bar{\Pi}=\left(\begin{array}{c}
-u \\
0 \\
0 \\
\ldots \\
0 \\
0
\end{array}\right)
$$

onde

- $\overline{\left(P_{1}^{\prime}-I\right)^{T}}$ é a matriz obtida de $\left(P_{1}^{\prime}-I\right)^{T}$, excluindo a 1092-ésima linha e a primeira coluna (relacionada à variável $\pi_{0}^{1}$ );

- $\bar{\Pi}$ é o vetor obtido de $\Pi$, excluindo a primeira componente; 
- $u$ é o vetor de dimensão $n-1$ composto pelas entradas $p_{1,2}^{(1)}, p_{1,3}^{(1)}, \ldots, p_{1, n}^{(1)}$, que são os coeficientes relacionados à variável $\pi_{0}^{1}$.

Esta é uma matriz bloco triangular inferior e a solução é encontrada resolvendo $(i)$ um sistema $\left(2^{11}-1\right) \times\left(2^{11}-1\right)$ cuja matriz de coeficientes é $\overline{\left(P_{1}^{\prime}-I\right)^{T}} ;(i i) \gamma-1$ sistemas $2^{11} \times 2^{11}$ onde as matrizes de coeficientes são $\left(P_{k}^{\prime}-I\right)^{T}, k=2, \ldots, \gamma$. Assim, teremos $\gamma-2$ sistemas (para $k=2, \ldots, \gamma-1)$ possuindo a mesma matriz de coeficientes. Sendo possível utilizar a mesma decomposição LU (custo $O\left(2^{11^{3}}\right)$ ). Como a resolução de sistemas triangulares é $O\left(2^{11^{2}}\right)$, o custo total é $O\left(2^{11^{3}}+2^{11^{2}} \gamma\right)$.

\subsubsection{Resultados}

O modelo NHMC depende dos parâmetros $\beta$ e $\gamma$ e de duas funções $g(k)$ e $f(\beta)$, enquanto que o modelo de Zhang depende apenas de $\alpha$ e $\beta$. A função $g(k)$ controla a taxa com que a concentração da proteína Cln3 aumenta na célula. Em nossos experimentos utilizamos

$$
g(k)=\frac{\gamma^{k-1}-1}{\gamma^{\gamma-1}-1} .
$$

Este é um outro exemplo de função que pode ser utilizada, no lugar da função $g$ da Eq. 4.2. Desta vez, optamos por uma mudança gradativa entre as matrizes. A função $f(\beta)$ utilizada foi

$$
f(\beta)=0.1 \cdot \beta^{2}+5 .
$$

Dado que $\alpha$ e $\beta$ representam a estocasticidade do sistema, seus valores devem estar de acordo com relação ao ruído, ou seja, quando $\beta$ é alto (menos ruído), $\alpha$ deve ser alto o suficiente para representar um nível de ruído próximo ao de $\beta$. Não seria adequado usar um valor alto para $\beta$ e um valor baixo para $\alpha$, pois assim o sistema iria se comportar de maneira instável em certo momento, e bastante estável em outro. Sendo assim, existem várias escolhas para $f(\beta)$.

Analisando a distribuição estacionária, comparamos o modelo NHMC com o modelo original de Zhang, para $\beta$ de 0.1 a 8.0. No modelo original, utilizamos três valores para $\alpha: 2,5$ e 10 . No modelo NHMC, utilizamos $\gamma=10,30$ e 100. Como podemos ver na Fig. 4.8, o modelo NHMC apresenta uma probabilidade mais baixa para o estado $\mathrm{G}_{1}$ estacionário, exceto quando o modelo original é muito ruidoso $(\alpha=2)$. Isto é esperado, pois no modelo NHMC a concentração da proteína Cln3 aumenta gradativamente, levando a célula a se dividir novamente.

Em seguida, analisamos também a probabilidade estacionária dos outros estados do ciclo celular, comparando o modelo NHMC com o modelo original de Zhang. Utilizamos $\beta=3$ para ambos os modelos, e no modelo original utilizamos $\alpha=2,5$ e 10 (Fig. 4.9a, 4.9b e 4.9c, respectivamente). Podemos ver que os estados da via possuem probabilidade maior no modelo NHMC.

Na Fig. 4.10 temos a probabilidade estacionária dos outros estados atratores. No modelo de Zhang, a probabilidade estacionária destes estados aumenta a medida em que aumentamos o valor de $\alpha$ (diminuímos o ruído). É interessante combinar as Fig. 4.9b e 4.10b e observar que para certos parâmetros, o modelo NHMC possui uma probabilidade mais alta com relação aos estados da via do ciclo celular, enquanto mantém a probabilidade dos outros estados atratores próxima do modelo original. 


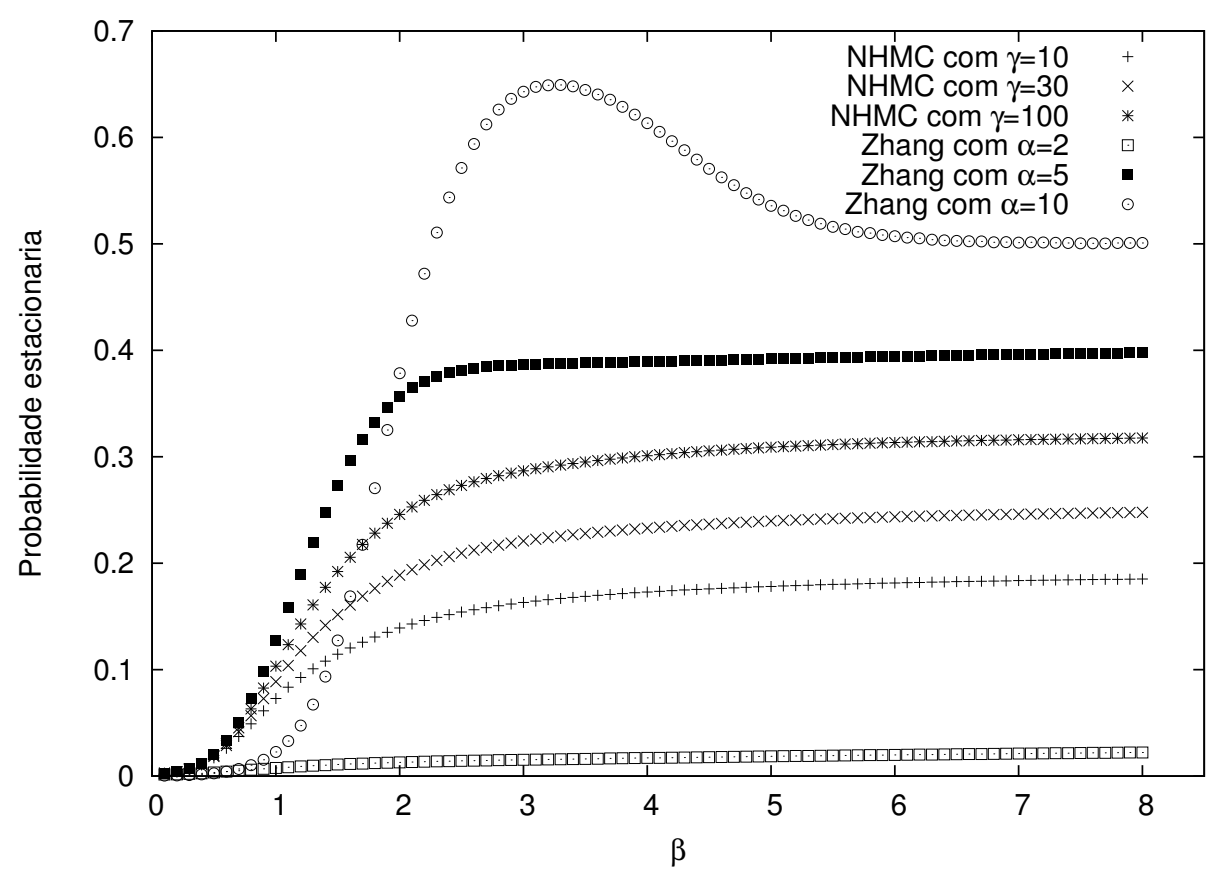

Figura 4.8: Comparação da probabilidade estacionária do estado $G_{1}$.

O modelo NHMC pode ser visto como uma extensão do modelo de (Zhang et al., 2006), onde modelamos explicitamente a saída do estado $\mathrm{G}_{1}$ estacionário para que uma nova divisão celular ocorra. Assim, no nosso modelo, os estados da via do ciclo celular apresentam uma probabilidade estacionária mais alta que no modelo original. Além disso, o comportamento peculiar do modelo de Zhang quando $\alpha=10$ (Fig. 4.8) não ocorre no nosso modelo devido à função $f(\beta)$. 


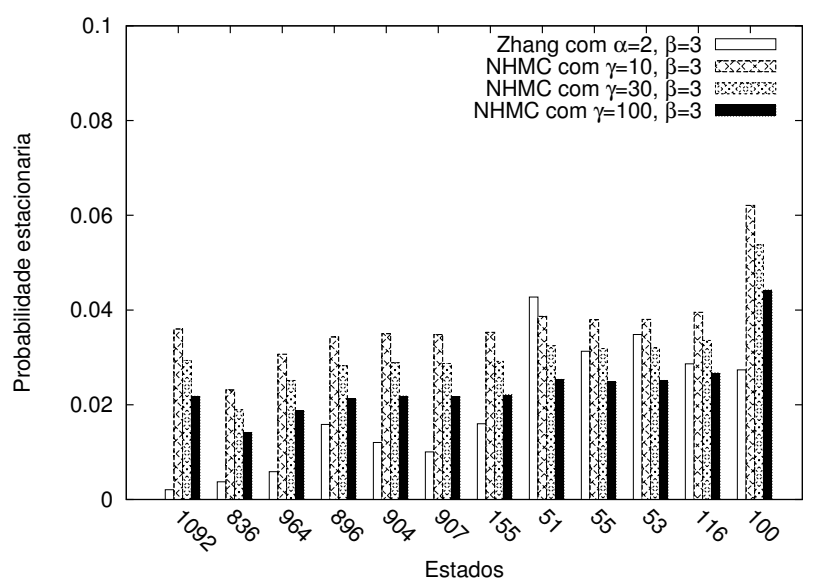

(a) $\alpha=2$

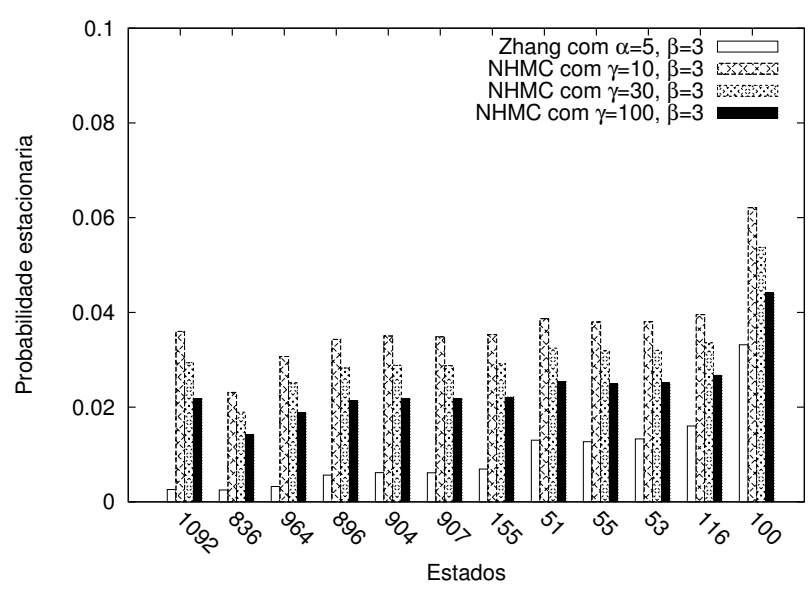

(b) $\alpha=5$

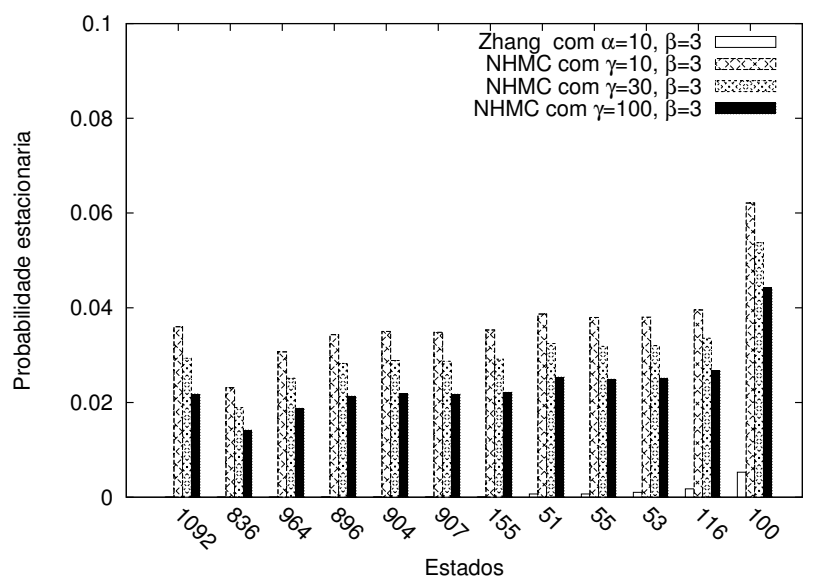

(c) $\alpha=10$

Figura 4.9: Probabilidade estacionária dos estados da via do ciclo celular. Cada estado é representado pelo seu correspondente valor decimal. 


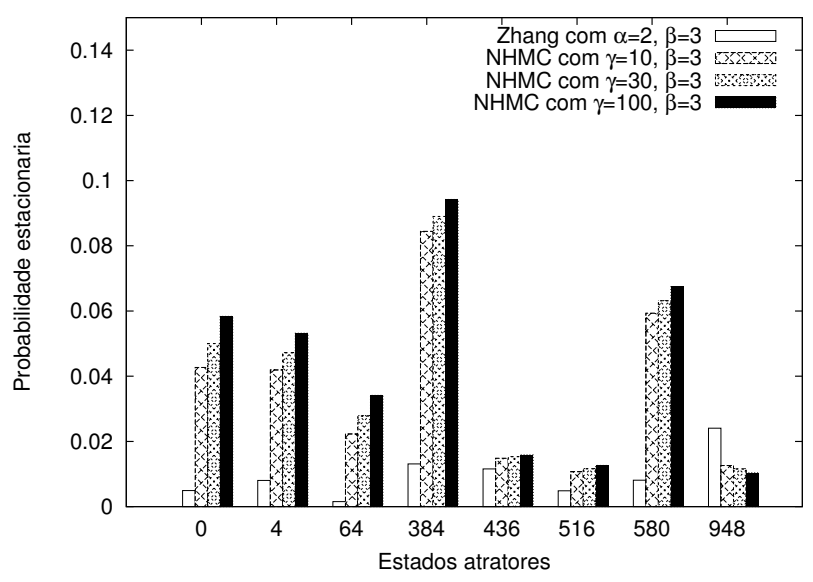

(a) $\alpha=2$

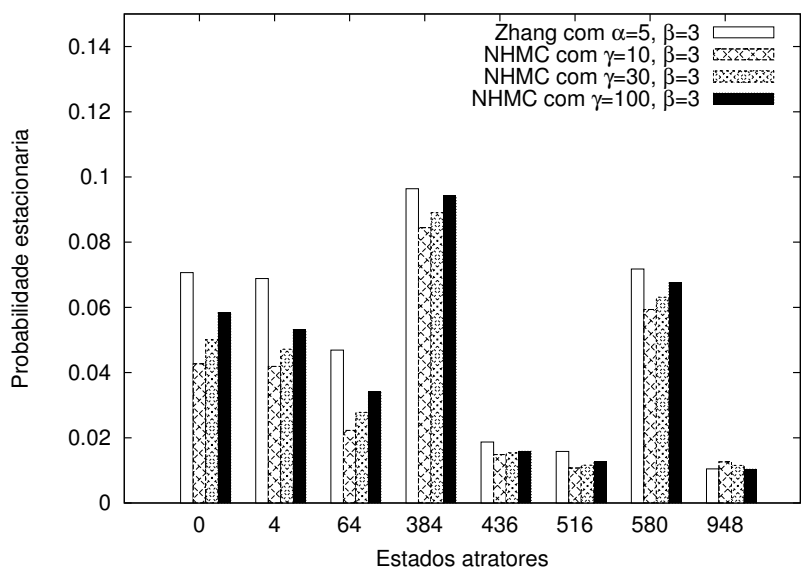

(b) $\alpha=5$

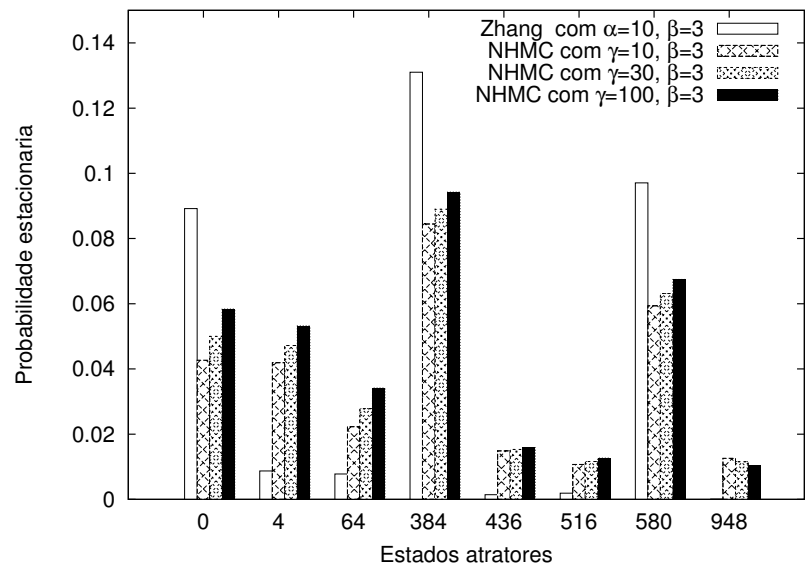

(c) $\alpha=10$

Figura 4.10: Probabilidade estacionária dos estados atratores. 


\section{Capítulo 5}

\section{Inferência de redes de regulação gênica}

Neste capítulo, trataremos de um problema chave na área de Biologia Sistêmica, que é a inferência de redes de regulação gênica a partir de dados temporais de expressão gênica. Dados temporais capturam uma visão mais completa do sistema do que dados estacionários (Sima et al., 2009). O algoritmo de inferência proposto é baseado no paradigma de crescimento de semente de genes. Neste contexto, definimos uma semente como sendo um conjunto pequeno de genes, que é alvo de interesse no estudo de algum fenômeno ou processo biológico. Assim, "crescer" a semente significa agregar outros genes a este conjunto, que estejam relacionados com o processo em questão.

O modelo matemático de GRN adotado é o de redes Booleanas com limiar e perturbação. Como veremos mais adiante, o algoritmo proposto tem como saída um conjunto de redes consistentes com os dados de entrada, e não apenas uma única rede. O objetivo é que, a partir dos dados de expressão gênica e de uma semente inicial, um pesquisador possa analisar um subconjunto de redes potencialmente significantes.

O algoritmo que propomos é composto por dois passos. O primeiro, é o passo de crescimento da semente, onde genes são adicionados à semente inicial. O segundo, é o passo de amostragem, onde várias redes são analisadas e algumas são selecionadas para fazerem parte da saída do algoritmo.

Antes de apresentarmos o algoritmo de inferência, iremos apresentar alguns trabalhos relacionados à inferência realizados durante o doutorado. Em particular, o coeficiente de determinação, ou CoD (Dougherty et al., 2000), foi estudado como medida de interação entre os genes de uma GRN (Seção 5.1). Na Seção 5.1.2, apresentaremos o coeficiente de determinação temporal para a inferência de redes, a partir de uma matriz de transição de estados de uma cadeia de Markov ergódica e sua respectiva distribuição estacionária.

Adotando o modelo de redes Booleanas com limiar, apresentamos na Seção 5.2 uma metodologia para gerar redes a partir de dados temporais, utilizando uma abordagem baseada em problemas de satisfação de restrições (CSP). Esta metodologia é utilizada no algoritmo de inferência baseado em crescimento de semente, apresentado na Seção 5.3. 


\subsection{Utilizando CoD para inferir relações entre genes}

Considere $X=\left\{x_{1}, x_{2}, \ldots, x_{n}\right\}$ um conjunto de $n$ genes, onde $x_{i} \in\{0,1\}, i=1, \ldots, n$. Seja $y \in X$ um gene alvo, e $Z \subseteq X$ um conjunto de genes preditores. O coeficiente de determinação, ou CoD, é uma medida normalizada do grau em que as observações em $Z$ podem melhorar a predição da expressão de $y$, se comparado com a ausência de observações. Para qualquer conjunto $Z$, o CoD relativo a $y$ é definido por

$$
\theta_{Z}(y)=\frac{\varepsilon_{\bullet}-\varepsilon_{Z}}{\varepsilon_{\bullet}}
$$

onde $\varepsilon_{\bullet}$ é o erro de Bayes para estimar $y$ na ausência de outras observações e $\varepsilon_{Z}$ é o erro de Bayes para $Z$ (Hashimoto et al., 2003).

Pela definição, temos que $0 \leq \theta_{Z}(y) \leq 1$, para qualquer $Z$ e $y$. Quando $\theta_{Z}(y) \approx 0$, significa que $Z$ não é um bom conjunto preditor de $y$. Por outro lado, quando $\theta_{Z}(y) \approx 1$, tomamos $Z$ como um bom conjunto de genes preditores.

\subsubsection{CoD estacionário}

O CoD pode ser calculado considerando ou não o fator tempo. Nesta seção iremos abordar o segundo caso, onde chamamos o $\mathrm{CoD}$ de estacionário. Em geral, um algoritmo que utiliza o CoD para inferir conexões entre genes, precisa estimar os erros $\varepsilon_{\bullet}$ e $\varepsilon_{Z}$ através dos dados de expressão gênica. Aqui, fizemos um estudo teórico, utilizando uma distribuição de probabilidade estacionária conhecida. No caso de dados estacionários, supomos que os dados são observações do sistema em equilíbrio, ou seja, são observações de estados atratores de uma rede Booleana.

Em (Higa et al., 2008) apresentamos um trabalho ${ }^{1}$ mostrando as dificuldades para recuperar as interações gênicas de uma rede previamente conhecida (ground truth), utilizando CoD estacionários. Com o modelo de (Zhang et al., 2006) obtemos a distribuição estacionária $\Pi$, usada para calcular os CoDs. Em um primeiro experimento, consideramos todos os conjuntos possíveis de genes preditores de tamanho 1 (um), para cada gene alvo possível. A rede apresentada na Fig. 5.1 contém as mesmas arestas do modelo de (Zhang et al., 2006). Uma aresta de $x_{i}$ para $x_{j}$ indica que o $\mathrm{CoD}$ foi calculado tal que $Z=\left\{x_{i}\right\}$ e $y=x_{j}$; o valor do $\mathrm{CoD}$ é indicado juntamente com a aresta. Como podemos perceber, maioria destes CoDs possuem valores relativamente baixos. O valor mais alto encontrado foi 0.8 , tomando $Z=\{\mathrm{SBF}\}$ e $y=\mathrm{Cln} 1$.

Em um outro experimento, encontramos CoDs para conjuntos preditores contendo dois genes. Considerando cada um dos 11 genes como alvo, calculamos os CoDs usando todos os subconjuntos preditores de dois genes possíveis. Na Fig. 5.2, apenas os CoDs maiores que 0.4 são apresentados. Os losangos contêm os valores dos CoDs, onde suas duas arestas de entrada indicam os dois genes preditores; a aresta de saída aponta para o gene alvo. Alguns valores parecem ser interessantes, como por exemplo, para $Z=\{\mathrm{Mcm} 1$, Sic1 $\}$ e $y=$ Clb1 temos o CoD igual a 0.61. De fato, Mcm1 e Sic1 influenciam o gene Clb1 na Fig. 3.2. Por outro lado, o CoD para $Z=\{\mathrm{Cln} 1, \mathrm{Mcm} 1\}$ e $y=\operatorname{SBF}$ vale 0.82, mas nenhum dos genes em $Z$ influencia o gene SBF, de acordo com a Fig. 3.2.

Vimos que, mesmo conhecendo a distribuição de probabilidade estacionária dos estados de

\footnotetext{
${ }^{1}$ Pôster premiado na área de Biologia Sistêmica - X-Meeting 2008.
} 


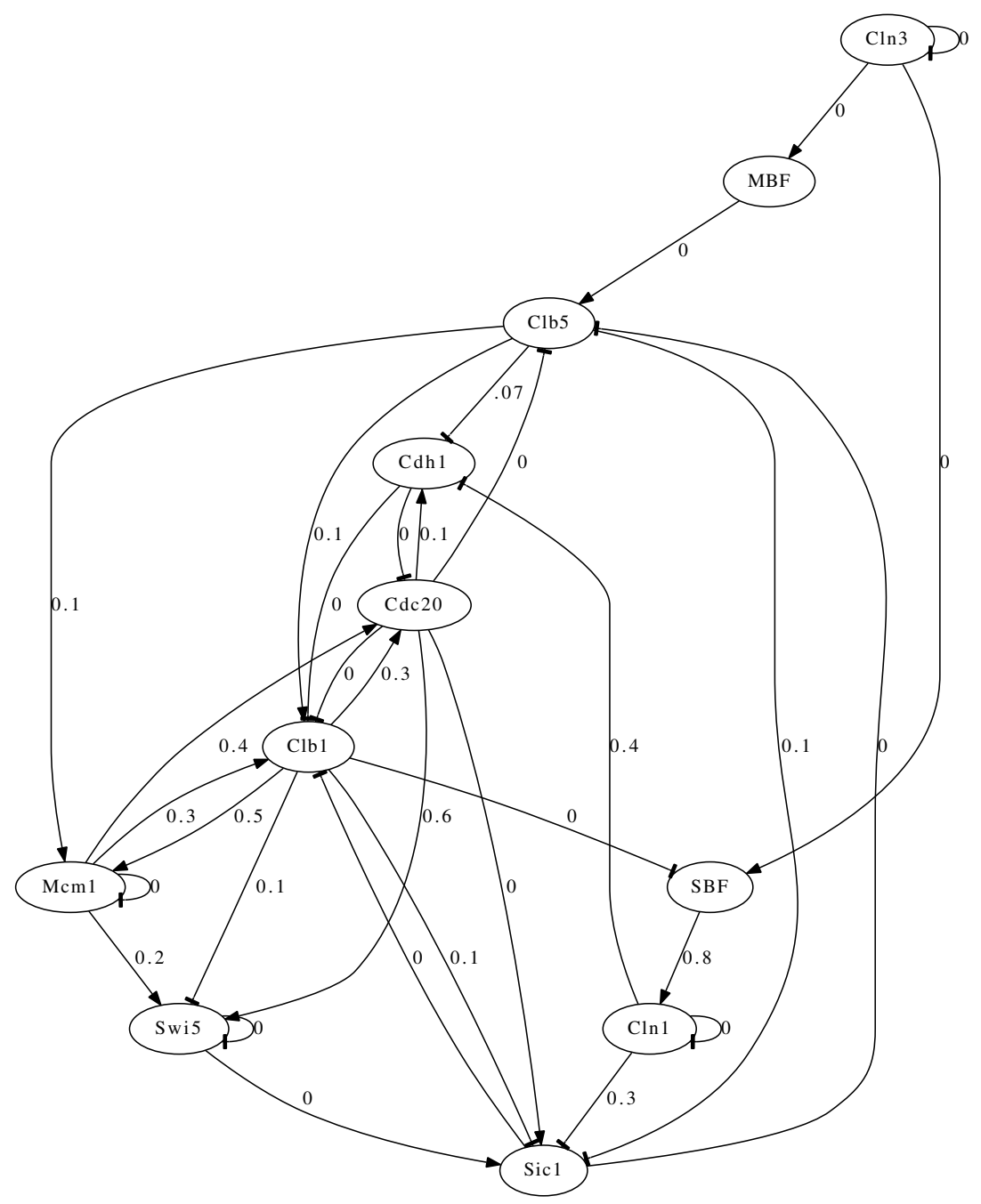

Figura 5.1: CoDs calculados a partir da distribuição estacionária do modelo de (Zhang et al., 2006), para conjuntos preditores de tamanho um. As arestas direcionadas apontam para o gene alvo.

uma rede Booleana, o $\mathrm{CoD}$ não produz resultados satisfatórios pare este caso em particular. Como tentamos inferir a rede do ciclo celular, que é um fenômeno bem definido e dividido em fases, acreditamos que o fator tempo é essencial neste caso. Sendo assim, propomos uma maneira para calcular o CoD levando em conta o fator tempo, apresentado a seguir.

\subsubsection{CoD temporal}

Seja $P$ a matriz de transição de estados $2^{n} \times 2^{n}$ de uma cadeia de Markov ergódica e $\Pi=$ $\left(\pi_{0}, \pi_{1}, \ldots, \pi_{2^{n}-1}\right)$ sua respectiva distribuição estacionária. Para cada par de estados, $\mathbf{x}_{i}$ e $\mathbf{x}_{j}$, $0 \leq i, j \leq 2^{n}-1$, temos que $p_{i, j}=\operatorname{Pr}\left[\mathbf{x}_{j}(t+1) \mid \mathbf{x}_{i}(t)\right]$ é a probabilidade de transição do estado $\mathbf{x}_{i}$ no tempo $t$ para o estado $\mathbf{x}_{j}$ no tempo $t+1$. Assim, chamamos os CoDs calculados a partir de $P$ e sua respectiva distribuição estacionária de CoDs temporais, ou tCoDs. Os tCoDs tentam capturar a dependência temporal dos genes no regime estacionário.

Dados $P$ e $\Pi$, podemos calcular a seguinte probabilidade para o par de estados $\mathbf{x}_{i}$ e $\mathbf{x}_{j}$ :

$$
m_{i, j}=\pi_{i} \cdot p_{i, j}
$$




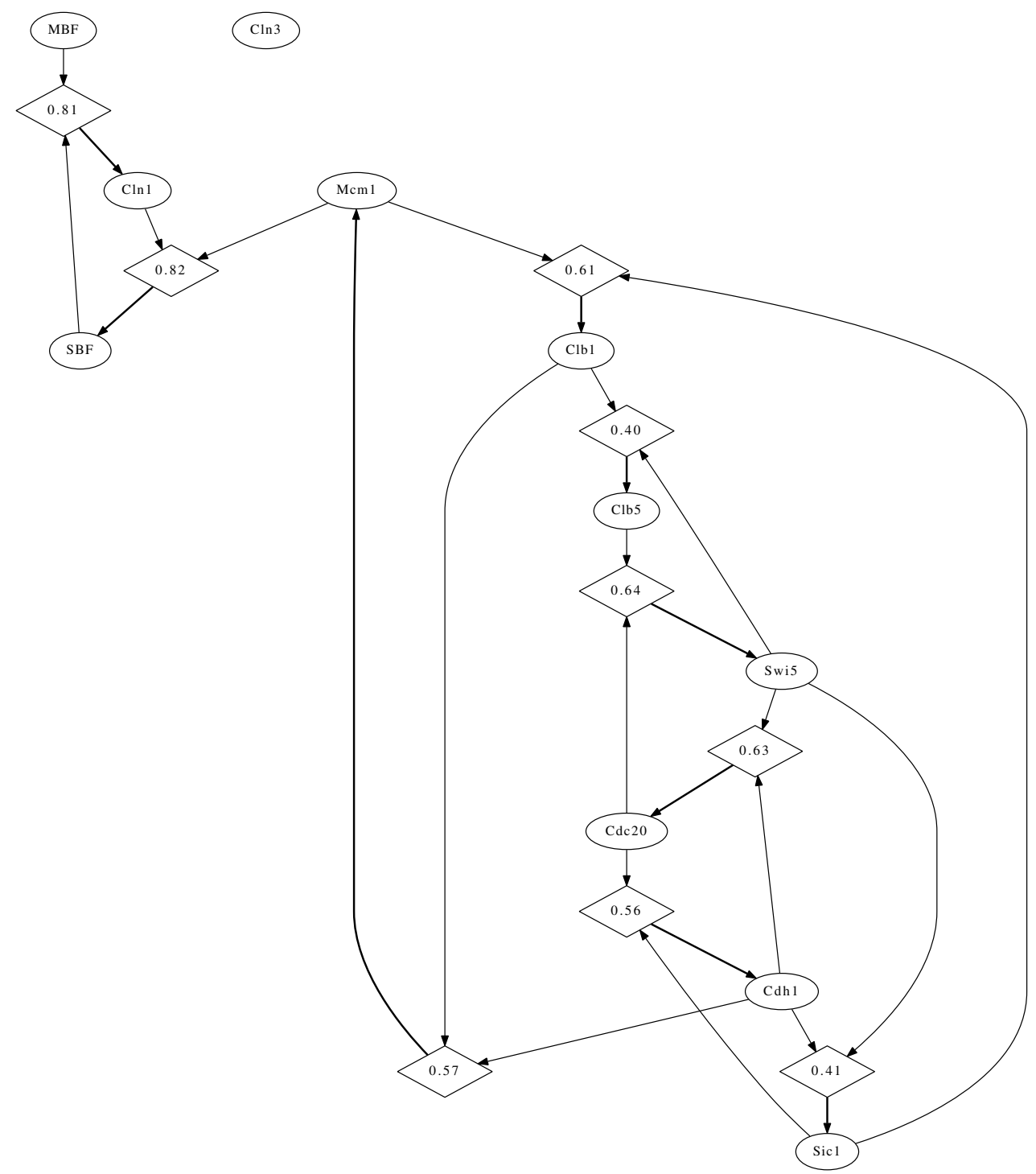

Figura 5.2: CoDs calculados considerando conjuntos preditores de tamanho dois. Os valores dos CoDs estão contidos nos losangos; as arestas de entrada do losango indicam os genes preditores e a aresta de saída aponta para o gene alvo.

Intuitivamente, $m_{i, j}$ pode ser vista como a taxa de transição (ou probabilidade de fluxo) de $\mathbf{x}_{i}$ para $\mathbf{x}_{j}$ (Ross, 2007).

Para obter $\varepsilon_{\bullet}$, vamos considerar um gene alvo $y=x_{\tau}, 1 \leq \tau \leq n$. Podemos então calcular a seguinte probabilidade:

$$
\operatorname{Pr}[y=\lambda]=\sum_{i, j} m_{i, j} \cdot \mathbf{1}\left[\mathbf{x}_{j}^{\tau}=\lambda\right]
$$

onde $\lambda \in\{0,1\}$ e $\mathbf{x}_{j}^{\tau} \in\{0,1\}$ denota o valor do gene $x_{\tau}$ no estado $\mathbf{x}_{j}$; a função indicadora $\mathbf{1}[p]$ vale 1 se a proposição $p$ é verdadeira, e 0 caso contrário. Como estamos observando o valor do gene alvo $x_{\tau}$ no estado $\mathbf{x}_{j}$, e o fluxo ocorre de $\mathbf{x}_{i}$ para $\mathbf{x}_{j}$, estamos observando o gene alvo no 
instante de tempo seguinte. Calculando $\operatorname{Pr}[y=1]$ e $\operatorname{Pr}[y=0]$ temos:

$$
\varepsilon_{\bullet}=\min \{\operatorname{Pr}[y=1], \operatorname{Pr}[y=0]\} .
$$

Agora, seja $Z=\left\{x_{j_{1}}, x_{j_{2}}, \ldots, x_{j_{k}}\right\}$ um conjunto de genes preditores, onde $j_{i}:\{1, \ldots, n\}$ $\rightarrow\{1, \ldots, n\}, i=1, \ldots, k$, é um mapeamento injetor. Seja $\mathbf{z}=\left(x_{j_{1}}, x_{j_{2}}, \ldots, x_{j_{k}}\right)$ o vetor formado pelos genes em $Z$, onde $\mathbf{z} \in\{0,1\}^{k}$. Dado que $\mathbf{z}$ possui $2^{k}$ configurações possíveis, podemos calcular para cada $\mathbf{z}_{\ell}, 0 \leq \ell \leq 2^{k}-1$, a seguinte probabilidade:

$$
\operatorname{Pr}\left[y=\lambda, \mathbf{z}_{\ell}\right]=\sum_{i, j} m_{i, j} \cdot \mathbf{1}\left[\mathbf{x}_{i}^{Z}=\mathbf{z}_{\ell} \text { e } \mathbf{x}_{j}^{\tau}=\lambda\right]
$$

onde $\mathbf{x}_{i}^{Z} \in\{0,1\}^{k}$ é o sub vetor composto pelos genes em $\mathbf{x}_{i}$ que correspondem aos genes em $Z$. Desta maneira, $\varepsilon_{\mathbf{Z}}$ é a soma dos erros ao predizer $y$ para cada configuração possível de $\mathbf{z}$ :

$$
\varepsilon_{Z}=\sum_{\ell=0}^{2^{k}-1} \min \left\{\operatorname{Pr}\left[y=0, \mathbf{z}_{\ell}\right], \operatorname{Pr}\left[y=1, \mathbf{z}_{\ell}\right]\right\} .
$$

Com os erros $\varepsilon_{\bullet}$ e $\varepsilon_{Z}$ podemos calcular o tCoD usando a Equação 5.1. Em (Higa et al., 2009a) foi mostrado que o tCoD pode ser utilizado em inferência de redes Booleanas com limiar.

\section{Teste de consistência}

Podemos ter vários conjuntos preditores $Z$ possuindo um CoD alto. Porém, pode ser que um certo conjunto não seja consistente com a matriz $P$. Antes de definir a consistência de um conjunto $Z$, precisamos definir uma tabela de próximos estados. Esta tabela possui duas colunas, estado atual e próximo estado. A primeira contém uma linha para cada estado $\mathbf{x}_{i}$ possível, $i=0, \ldots, 2^{n}-1$. Para preencher a segunda coluna, olhamos a matriz $P$. Em um processo biológico estável, a matriz $P$ tem a característica de que cada linha possui uma única probabilidade relativamente alta, se comparada com as demais. Digamos que esta probabilidade alta, na linha correspondente ao estado $\mathbf{x}_{i}$, esteja associada à transição $\mathbf{x}_{i} \rightarrow \mathbf{x}_{j}$. Assim, a segunda coluna correspondente à linha $\mathbf{x}_{i}$ será preenchida com o estado $\mathbf{x}_{j}$. Denotamos o próximo estado de $\mathbf{x}_{i}$ por $\mathbf{x}_{i}^{+}$. Na Tabela 5.1 temos um exemplo de tabela de próximos estados.

\begin{tabular}{|ccccc||ccccc|}
\hline \multicolumn{5}{|c|}{$\mathbf{x}_{i}$} & & \multicolumn{5}{c|}{$\mathbf{x}_{i}^{+}$} \\
\hline$x_{1}$ & $x_{2}$ & $\ldots$ & $x_{n-1}$ & $x_{n}$ & $x_{1}$ & $x_{2}$ & $\ldots$ & $x_{n-1}$ & $x_{n}$ \\
\hline \hline 0 & 0 & $\ldots$ & 0 & 0 & 1 & 1 & $\ldots$ & 0 & 1 \\
0 & 0 & $\ldots$ & 0 & 1 & 0 & 1 & $\ldots$ & 0 & 0 \\
$\vdots$ & $\vdots$ & $\vdots$ & $\vdots$ & $\vdots$ & $\vdots$ & $\vdots$ & $\vdots$ & $\vdots$ & $\vdots$ \\
1 & 1 & $\ldots$ & 1 & 0 & 1 & 1 & $\ldots$ & 1 & 0 \\
1 & 1 & $\ldots$ & 1 & 1 & 0 & 1 & $\ldots$ & 0 & 1 \\
\hline
\end{tabular}

Tabela 5.1: Tabela de próximos estados.

Seja um conjunto preditor $Z=\left\{x_{j_{1}}, x_{j_{2}}, \ldots, x_{j_{k}}\right\}$ e um gene alvo $y=x_{\tau}$. Para cada configu- 
ração possível do vetor $\mathbf{z}_{\ell}, \ell=0,1, \ldots, 2^{k}-1$, podemos calcular o somatório

$$
\sigma_{\ell}=\sum_{i=0}^{2^{n}-1} \mathbf{x}_{i}^{+(\tau)} \cdot \mathbf{1}\left[\mathbf{x}_{i}^{Z}=\mathbf{z}_{\ell}\right]
$$

onde $\mathbf{x}_{i}^{+(\tau)}$ denota o valor do gene $x_{\tau}$ no vetor $\mathbf{x}_{i}^{+}$. Como haverá exatamente $2^{n-k}$ linhas da tabela em que $\mathbf{x}_{i}^{Z}=\mathbf{z}_{\ell}$, temos que $0 \leq \sigma_{\ell} \leq 2^{n-k}$. Dizemos que um conjunto $Z$ é consistente com $P$ e $y$, se $\sigma_{\ell}=0$ ou $\sigma_{\ell}=2^{n-k}$, para $\ell=0, \ldots, 2^{k}-1$. Assim, para uma configuração fixa de $\left(x_{j_{1}}, x_{j_{2}}, \ldots, x_{j_{k}}\right)$, o valor de $x_{\tau}$ permanece fixo em 0 ou 1 .

\section{Resultados}

Em nossos experimentos, calculamos os tCoDs usando a matriz de transição do modelo proposto por (Zhang et al., 2006), com os parâmetros $\alpha=5$ e $\beta=6$. Consideramos cada um dos 11 genes do modelo como gene alvo, e para cada gene, todos os subconjuntos $Z$ de tamanho $k=1, \ldots, 6$ foram considerados.

Para analisar a precisão do tCoD para capturar as relações entre os genes, seguimos com a seguinte abordagem. Para cada gene alvo $y$, nós identificamos o verdadeiro conjunto preditor $\mathcal{Z}$, de acordo com a Fig. 3.2. Por exemplo, para $y=\mathrm{SBF}$, temos $\mathcal{Z}=\{\mathrm{Cln} 3$, SBF, Clb1 $\}$, e o respectivo tCoD é 0.96 . A Tabela 5.2 resume o resultado deste experimento. Note que sempre temos $y \in \mathcal{Z}$ pois de acordo com o modelo de redes Booleanas com limiar, todo gene depende dele mesmo quando o input é nulo (veja Eq. 2.9).

\begin{tabular}{|c|l|c|}
\hline$y$ & \multicolumn{1}{|c|}{$\mathcal{Z}$} & $\theta_{\mathcal{Z}}(Y)$ \\
\hline \hline Cln3 & Cln3 & 0.0 \\
\hline MBF & Cln3, MBF, Clb1 & 0.95 \\
\hline SBF & Cln3, SBF, Clb1 & 0.96 \\
\hline Cln2 & SBF, Cln2 & 0.92 \\
\hline Cdh1 & Cln2, Cdh1, Cdc20, Clb5, Clb1 & 0.98 \\
\hline Swi5 & Swi5, Cdc20, Clb1, Mcm1 & 0.86 \\
\hline Cdc20 & Cdh1, Cdc20, Clb1, Mcm1 & 0.97 \\
\hline Clb5 & MBF, Cdc20, Clb5, Sic1 & 0.90 \\
\hline Sic1 & Cln2, Swi5, Cdc20, Clb5, Sic1, Clb1 & 0.98 \\
\hline Clb1 & Cdh1, Cdc20, Clb5, Sic1, Clb1, Mcm1 & 0.96 \\
\hline Mcm1 & Clb5, Clb1, Mcm1 & 0.80 \\
\hline
\end{tabular}

Tabela 5.2: Tabela contendo valores de $t C o D s$ calculados utilizando o verdadeiro conjunto preditor.

Como podemos ver na Tabela 5.2, o menor tCoD é 0.80, quando $y=\mathrm{Mcm} 1$, exceto para o Cln3 onde o tCoD é zero; como este gene possui apenas ele mesmo como preditor, não há ganho em termos de informação para predizer sua expressão gênica. Assim, assumimos um limiar $\mathcal{L}=0.8$, podendo afirmar que todo verdadeiro conjunto preditor $\mathcal{Z}$ possui tCoD maior do que $\mathcal{L}$.

Dado o limiar $\mathcal{L}$ e um gene alvo $y$, podemos obter todos os subconjuntos $Z$ tal que $\theta_{Z}(y) \geq \mathcal{L}$ e testar sua consistência. Na Tabela 5.3 , para cada gene $y$ e cada valor de $k$, indicamos a razão $T / T_{c}$, onde $T$ é o número total de conjuntos $Z$ onde $\theta_{Z}(y) \geq \mathcal{L}$ e $T_{c}$ é o número total de conjuntos consistentes. Em cada linha, existe um valor em negrito, que corresponde ao tamanho 
$k$ do verdadeiro conjunto preditor.

\begin{tabular}{|c|c|c|c|c|c|c|}
\hline \multirow{2}{*}{$y$} & \multicolumn{7}{|c|}{$k$} \\
\cline { 2 - 7 } & 1 & 2 & 3 & 4 & 5 & 6 \\
\hline \hline Cln3 & $\mathbf{0 / 0}$ & $0 / 0$ & $0 / 0$ & $0 / 0$ & $0 / 0$ & $0 / 0$ \\
\hline MBF & $1 / 0$ & $10 / 0$ & $\mathbf{4 5 / 1}$ & $120 / 8$ & $210 / 28$ & $252 / 56$ \\
\hline SBF & $0 / 0$ & $12 / 0$ & $\mathbf{6 1} / \mathbf{1}$ & $175 / 8$ & $305 / 28$ & $363 / 56$ \\
\hline Cln2 & $2 / 1$ & $\mathbf{1 9} / \mathbf{1 0}$ & $81 / 45$ & $204 / 120$ & $336 / 210$ & $378 / 252$ \\
\hline Cdh1 & $1 / 0$ & $10 / 0$ & $45 / 0$ & $120 / 0$ & $\mathbf{2 1 0} / \mathbf{1}$ & $252 / 6$ \\
\hline Swi5 & $0 / 0$ & $1 / 0$ & $9 / 1$ & $\mathbf{3 6 / 8}$ & $84 / 28$ & $126 / 56$ \\
\hline Cdc20 & $0 / 0$ & $0 / 0$ & $8 / 0$ & $\mathbf{5 7 / 1}$ & $164 / 7$ & $257 / 21$ \\
\hline Clb5 & $0 / 0$ & $0 / 0$ & $1 / 0$ & $\mathbf{8} / \mathbf{1}$ & $30 / 7$ & $65 / 21$ \\
\hline Sic1 & $1 / 0$ & $10 / 0$ & $45 / 0$ & $120 / 0$ & $210 / 0$ & $\mathbf{2 5 2} / \mathbf{1}$ \\
\hline Clb1 & $0 / 0$ & $0 / 0$ & $2 / 0$ & $21 / 0$ & $75 / 0$ & $\mathbf{1 3 8 / 1}$ \\
\hline Mcm1 & $0 / 0$ & $1 / 1$ & $\mathbf{9} / \mathbf{9}$ & $36 / 36$ & $84 / 84$ & $126 / 126$ \\
\hline
\end{tabular}

Tabela 5.3: $T / T_{c}$ para cada gene alvo e $k=1, \ldots, 6$.

A dificuldade desta abordagem está no fato de que precisamos obter uma matriz de transição de estados $P$ de uma cadeia de Markov e sua correspondente distribuição estacionária $\Pi$ para calcularmos os tCoDs. Uma abordagem para recuperar uma matriz de transição a partir de dados pode ser utilizada neste caso, como por exemplo, proposta em (Martins-Jr et al., 2009). Nossos estudos teóricos mostram que modelos baseados em cadeias de Markov podem ser utilizados em processos de inferência de redes. Quando poucas amostras de dados temporais estão disponíveis, propomos uma abordagem baseada em problemas de satisfação de restrições, apresentada nas próximas seções.

\subsection{Gerando redes consistentes usando CSP}

Como vimos na Seção 2.1, os dados de expressão gênica podem ser temporais ou estacionários. Aqui, estaremos tratando de dados temporais. Apresentaremos nesta seção uma abordagem baseada em problemas de satisfação de restrições (CSP) para gerar redes Booleanas com limiar (tBN) consistentes com os dados temporais disponíveis. Definiremos a consistência de uma rede mais adiante. Em suma, utilizamos os dados e o modelo tBN para gerar restrições, e utilizamos um solver CSP para encontrar soluções para o problema. Neste contexto, cada solução é uma matriz de regulação representando as interações gênicas de uma tBN.

\subsubsection{Formulando o CSP}

Para colocar o problema de gerar tBNs a partir de dados temporais no contexto de CSP, temos que definir o conjunto de variáveis, o domínio destas variáveis e o conjunto de restrições. Considere que os genes são $x_{1}, x_{2}, \ldots, x_{n}$. Assim, a matriz de regulação é definida por $A=\left\{a_{i, j}\right.$ : $1 \leq i, j \leq n\}$, onde $a_{i, j} \in\{-1,0,1\}$ (veja Eq. 2.7). O que desejamos é encontrar matrizes de regulação (tBNs) a partir de dados temporais. Relembrando o modelo de redes Booleanas com limiar, uma propriedade importante é que cada linha da matriz de regulação é independente uma da outra. Assim, para cada gene $x_{i}, i=1,2, \ldots, n$, definimos um CSP $\mathcal{C}_{i}$ por um conjunto de 
$n$ variáveis $V_{i}=\left\{a_{i, 1}, a_{i, 2}, \ldots, a_{i, n}\right\}$, correspondente a $i$-ésima linha da matriz $A$; uma coleção de domínios $D_{i, 1}, D_{i, 2}, \ldots, D_{i, n}$, onde cada $D_{i, j}=\{-1,0,1\}$; e um conjunto de restrições a ser definido.

\subsubsection{Gerando restrições do CSP}

Para gerar as restrições do CSP utilizamos os dados temporais de expressão gênica. Seja $\mathbf{T}=\{s(1), s(2), \ldots, s(m)\}$ um conjunto de dados temporais consistindo de $m$ instantes de tempo, onde $s(t) \in\{0,1\}^{n}$, para $t=1,2, \ldots, m$. Assumimos que existe uma ordem em que estas amostras foram obtidas:

$$
s(1) \rightarrow s(2) \rightarrow \cdots \rightarrow s(m) .
$$

Cada amostra $s(t)$ pode ser vista como um estado no diagrama de transição de estados de uma tBN. Quando uma tBN reproduz a sequência de estados dada por $\mathbf{T}$ dizemos que a tBN é consistente com os dados. Podem existir várias redes consistentes com $\mathbf{T}$, como também pode não existir rede alguma. Encontrar tBNs consistentes é um problema inverso mal posto difícil de ser tratado.

Uma maneira direta de gerar redes consistentes com um conjunto de dados é realizar uma busca exaustiva, testando a consistência de cada rede. O número total de matrizes (tBNs) é $3^{n^{2}}$, mas como as linhas da matriz são independentes, podemos testar a consistência de cada linha separadamente. O total de linhas é $3^{n}$, e como temos $n$ linhas, o total de linhas testadas é $n 3^{n}$. Esta abordagem foi utilizada em (Lau et al., 2007).

Em (Higa et al., 2010), exploramos propriedades matemáticas de redes Booleanas com limiar para evitar a busca exaustiva. Uma extensão deste trabalho foi apresentada em (Higa et al., 2011b), onde formalizamos o problema de encontrar tBNs consistentes no contexto de problemas de satisfação de restrições. A seguir, apresentamos como as restrições do CSP são obtidas através dos dados temporais e do modelo tBN.

\section{Primeiro conjunto de restrições}

O primeiro conjunto de restrições é gerado observando os dados temporais em triplas, $s(t-$ $1), s(t)$ e $s(t+1)$. Iremos utilizar o termo "estado" quando nos referirmos a uma amostra $s(t)$. Assim, note que se dois estados consecutivos $s(t-1)$ e $s(t)$ diferem apenas em um único gene $x_{k}$, então qualquer gene $x_{i}$ que tem o seu valor alterado de $s(t)$ para $s(t+1)$ é diretamente regulado por $x_{k}$, de acordo com o modelo tBN.

Para ilustrar esta situação, considere os dados temporais da Tabela 5.4. Observando os estados $s(1)$ e $s(2)$ podemos ver que apenas o gene $x_{2}$ tem o seu valor alterado, de 1 para 0 . Além disso, olhando para os estados $s(2)$ e $s(3)$, podemos ver que $x_{3}$ tem o seu valor alterado de 0 para 1 . Pelo modelo tBN, esta alteração em $x_{3}$ foi necessariamente causada pelo gene $x_{2}$. De fato, $x_{2}$ inibe $x_{3}$ no instante de tempo $t=1$. Em $t=2$, o gene $x_{2}$ se torna inativo (por auto degradação ou pelo gene $x_{1}$, que é o único gene expresso em $t=1$ ). A partir do momento em que $x_{2}$ é inibido, o gene $x_{3}$ é ativado. Neste caso podemos dizer que $x_{1}$ é o gene responsável por essa ativação, pois é o único gene expresso em $t=2$. Com esta ideia, formulamos a seguinte proposição: 


\begin{tabular}{|c||c|c|c|c|}
\hline & $x_{1}(t)$ & $x_{2}(t)$ & $x_{3}(t)$ & $x_{4}(t)$ \\
\hline \hline$s(1)$ & 1 & $\mathbf{1}$ & 0 & 0 \\
\hline$s(2)$ & 1 & $\mathbf{0}$ & $\mathbf{0}$ & 0 \\
\hline$s(3)$ & 1 & 0 & $\mathbf{1}$ & 0 \\
\hline$s(4)$ & 1 & 0 & 1 & 1 \\
\hline$s(5)$ & 0 & 0 & 1 & 1 \\
\hline
\end{tabular}

Tabela 5.4: Um exemplo de dados temporais contendo 5 amostras e 4 genes. De $s(1)$ para $s(2)$ apenas o gene $x_{2}$ tem o seu valor alterado. De $s(2)$ para $s(3)$ vimos que $x_{3}$ tem seu valor alterado para 1 . Pelo modelo $t B N$, esta alteração foi causada necessariamente pelo gene $x_{2}$.

Proposição 1. Sejam $s(t-1), s(t)$ e $s(t+1)$ três estados consecutivos de uma rede Booleana com limiar. Se os estados $s(t-1)$ e $s(t)$ diferem apenas em um único gene $x_{k}$, então para cada gene $x_{i}$ tal que $x_{i}(t) \neq x_{i}(t+1)$, temos que $x_{k}$ regula $x_{i}$ diretamente, ou seja, $a_{i, k} \neq 0$ na matriz de regulação.

Demonstração. Suponha que os estados $s(t-1)$ e $s(t)$ diferem apenas com relação ao gene $x_{k}$, e que exista um pelo menos um gene $x_{i}$ tal que $x_{i}(t) \neq x_{i}(t+1)$. Assim, temos que os somatórios $\sum_{j} a_{i, j} x_{j}(t-1)$ e $\sum_{j} a_{i, j} x_{j}(t)$ possuem sinais diferentes. Dado que $x_{k}$ é o único gene possuindo valores diferentes entre $s(t-1)$ e $s(t)$, esta diferença de sinal deve, obrigatoriamente, ter sido causada por $x_{k}$. Portanto, $a_{i, k} \neq 0$.

\section{Segundo conjunto de restrições}

Para gerar o segundo conjunto de restrições, levamos em consideração dois estados consecutivos, $s(t)$ e $s(t+1)$. Uma observação importante é que apenas os genes expressos no instante de tempo $t$ podem alterar a expressão dos genes no tempo $t+1$. Isto pode ser visto pelas Eq. 2.8 e 2.9. Assim, os genes expressos podem nos dar uma ideia de quais genes podem estar regulando outros genes, apesar de que em alguns casos, o tipo de regulação (ativação ou inibição) não pode ser determinado desta maneira. No entanto, o input dado pelo somatório da Eq. 2.8 pode nos ajudar a encontrar relações de regulação a partir dos dados temporais. Por exemplo, se observarmos que um gene $x_{i}$ tem o seu valor alterado de 0 (no tempo $t$ ) para 1 (no tempo $t+1$ ), podemos deduzir que o input no tempo $t$ é positivo, e que apenas os genes expressos em $t$ podem ser responsáveis por este input positivo.

Proposição 2. Para cada gene $x_{i}$, as transições de $x_{i}(t)$ para $x_{i}(t+1)$ geram restrições envolvendo as variáveis $a_{i, j}$ de acordo com a Tabela 5.5 .

Demonstração. Vamos provar a primeira restrição; as demais restrições podem ser demonstradas de maneira análoga. Desejamos provar que se $x_{i}(t)=1$ e $x_{i}(t+1)=0$, então $\sum_{j: x_{j}(t)=1} a_{i, j}<0$. De acordo com as Eq. 2.8 e 2.9, a única maneira de alterar o valor de um gene $x_{i}$ de 1 (no tempo $t$ ) para 0 (no tempo $t+1$ ) é quando $(i) \sum_{j} a_{i, j} x_{j}(t)<0$. Considerando apenas os genes $x_{i}$ tal que $x_{j}(t)=1$ (pois apenas estes genes influenciam no somatório), podemos reescrever $(i)$ como $\sum_{j: x_{j}(t)=1} a_{i, j}<0$. 


\begin{tabular}{|c|c|c|}
\hline$x_{i}(t)$ & $x_{i}(t+1)$ & Restrições \\
\hline \hline 1 & 0 & $\sum_{j: x_{j}(t)=1} a_{i, j}<0$ \\
\hline 0 & 1 & $\sum_{j: x_{j}(t)=1} a_{i, j}>0$ \\
\hline 0 & 0 & $\sum_{j: x_{j}(t)=1} a_{i, j} \leq 0$ \\
\hline 1 & 1 & $\sum_{j: x_{j}(t)=1} a_{i, j} \geq 0$ \\
\hline
\end{tabular}

Tabela 5.5: Restrições geradas a partir da análise de pares de estados $s(t)$ e $s(t+1)$. Por exemplo, na primeira linha temos o caso em que $x_{i}(t)=1$ e $x_{i}(t+1)=0$. Portanto, sabemos que o somatório na terceira coluna deve ser necessariamente negativo.

Para ver um exemplo, considere os dados temporais da Tabela 5.4. No estado $s(3)$ existem dois genes expressos, $x_{1}$ e $x_{3}$. Estes genes são os únicos que podem contribuir para com o sinal do input em cada gene no próximo instante de tempo. Observando o gene $x_{4}$, podemos ver que o seu valor é alterado de $0(t=3)$ para $1(t=4)$. De acordo com as Eq. 2.8 e 2.9, neste caso o input deve ser positivo, ou seja, $\sum_{j=1}^{4} a_{4, j} x_{j}(3)>0$. Considerando apenas os genes expressos em $t=3$, devemos ter $a_{4,1}+a_{4,3}>0$. Portanto, podemos ter

$$
\begin{array}{lll}
a_{4,1}=1 & \text { e } & a_{4,3}=1, \mathrm{ou} \\
a_{4,1}=1 & \text { e } & a_{4,3}=0, \mathrm{ou} \\
a_{4,1}=0 & \text { e } & a_{4,3}=1 .
\end{array}
$$

O mesmo procedimento pode ser aplicado para todos os genes, gerando diversas restrições para o CSP.

\section{Terceiro conjunto de restrições}

O terceiro conjunto de restrições é gerado observando pares de estados consecutivos nos dados temporais. Seja $t_{1}$ e $t_{2}$ dois instantes de tempo tal que

$$
\cdots s\left(t_{1}\right) \rightarrow s\left(t_{1}+1\right) \rightarrow \cdots \rightarrow \cdots s\left(t_{2}\right) \rightarrow s\left(t_{2}+1\right) \cdots .
$$

Suponha que os estados $s\left(t_{1}\right)$ e $s\left(t_{2}\right)$ são muito parecidos. Assim, a diferença entre $s\left(t_{1}+1\right)$ e $s\left(t_{2}+1\right)$ deve ser causada pelos genes diferentemente expressos entre seus estados predecessores. Por exemplo, vamos supor que $s\left(t_{1}\right)$ e $s\left(t_{2}\right)$ diferem apenas em um único gene, neste caso, o gene $x_{4}$ :

$$
s\left(t_{1}\right)=\left(\begin{array}{l}
1 \\
0 \\
1 \\
\mathbf{0}
\end{array}\right), s\left(t_{2}\right)=\left(\begin{array}{l}
1 \\
0 \\
1 \\
\mathbf{1}
\end{array}\right) \text {. }
$$


Suponha também que sucessão de estados ocorre da seguinte maneira:

$$
\left(\begin{array}{l}
1 \\
0 \\
1 \\
0
\end{array}\right) \longrightarrow\left(\begin{array}{l}
0 \\
0 \\
0 \\
0
\end{array}\right) \rightarrow \cdots \rightarrow\left(\begin{array}{l}
1 \\
0 \\
1 \\
1
\end{array}\right) \longrightarrow\left(\begin{array}{l}
1 \\
1 \\
1 \\
1
\end{array}\right)
$$

Portanto, a diferença entre $s\left(t_{1}+1\right)$ e $s\left(t_{2}+1\right)$ neste caso deve ser causada pela diferença de expressão do gene $x_{4}$. Pare este exemplo, considere o gene $x_{1}$. No primeiro par de estados, podemos ver que o valor passa de 1 para 0 , e no segundo par de estados não há mudança no valor, permanecendo em 1 . Seja $I$ o input total no gene $x_{1}$ gerado pelos genes cujos valores são os mesmos em $s\left(t_{1}\right)$ e $s\left(t_{2}\right), M$ o input gerado por $x_{4}$ no instante de tempo $t_{1}$, e $\bar{M}$ o input gerado por $x_{4}$ em $t_{2}$. Portanto, para explicar a mudança do valor de $x_{1}$ no primeiro par, devemos ter

$$
I+M<0
$$

para que $x_{1}$ seja inibido de $t_{1}$ para $t_{1}+1$, e

$$
I+\bar{M} \geq 0
$$

para que o valor de $x_{1}$ permaneça em 1 de $t_{2}$ para $t_{2}+1$. Como $a_{i, j}$ representa a relação de regulação do gene $x_{j}$ sobre $x_{i}$, podemos calcular $I, M$ e $\bar{M}$ como segue:

$$
\begin{gathered}
I=\left(\begin{array}{lll}
a_{1,1} & a_{1,2} & a_{1,3}
\end{array}\right) \cdot\left(\begin{array}{l}
1 \\
0 \\
1
\end{array}\right)=a_{1,1}+a_{1,3}, \\
M=a_{1,4} \cdot 0=0 \mathrm{e} \\
\bar{M}=a_{1,4} \cdot 1=a_{1,4} .
\end{gathered}
$$

Assim, temos

$$
\left\{\begin{array} { l } 
{ I + M < 0 } \\
{ I + \overline { M } \geq 0 }
\end{array} \rightarrow \left\{\begin{array} { l } 
{ a _ { 1 , 1 } + a _ { 1 , 3 } + 0 < 0 } \\
{ a _ { 1 , 1 } + a _ { 1 , 3 } + a _ { 1 , 4 } \geq 0 }
\end{array} \rightarrow \left\{a_{1,4}>0 .\right.\right.\right.
$$

Sendo assim, devemos ter obrigatoriamente $a_{1,4}=1$ na matriz de regulação para que a tBN seja consistente com os dados temporais. Se $s\left(t_{1}\right)$ e $s\left(t_{2}\right)$ diferem em mais do que um único gene, algumas hipóteses de regulação podem ser geradas. De fato, geramos um sistema de desigualdades com os inputs de cada gene, para cada combinação de pares consecutivos.

Proposição 3. Sejam $t_{a}$ e $t_{b}, t_{a} \neq t_{b}$, dois instantes de tempo. As transições de $x_{i}\left(t_{a}\right)$ para $x_{i}\left(t_{a}+1\right)$ e de $x_{i}\left(t_{b}\right)$ para $x_{i}\left(t_{b}+1\right)$ geram restriçôes para as varáveis $a_{i, j}$ de acordo com a Tabela 5.6.

Demonstração. Vamos provar a primeira restrição; as demais restrições podem ser demonstradas 
de maneira análoga. Logo, queremos mostrar que se $\left.x_{i}\left(t_{a}\right)=1, x_{i}\left(t_{a}+1\right)=0\right), x_{i}\left(t_{b}\right)=0$ e $x_{i}\left(t_{b}+1\right)=1$, então

$$
\sum_{j: x_{j}\left(t_{a}\right)=1 \mathrm{e} x_{j}\left(t_{b}\right)=0} a_{i, j}-\sum_{j: x_{j}\left(t_{b}\right)=1 \mathrm{e} x_{j}\left(t_{a}\right)=0} a_{i, j}<0 .
$$

Considerando a mudança de $x_{i}\left(t_{a}\right)=1$ para $x_{i}\left(t_{a}+1\right)=0$, pela Proposição 2 , temos que $\sum_{j: x_{j}\left(t_{a}\right)=1} a_{i, j}<0$. Podemos escrever o conjunto de índices de todos os genes expressos no tempo $t_{a}$, $E\left(t_{a}\right)=\left\{j: x_{j}\left(t_{a}\right)=1\right\}$, como uma união de dois conjuntos disjuntos:

$$
E\left(t_{a}\right)=\left\{j: x_{j}\left(t_{a}\right)=1 \text { e } x_{j}\left(t_{b}\right)=0\right\} \cup\left\{j: x_{j}\left(t_{a}\right)=1 \text { e } x_{j}\left(t_{b}\right)=1\right\}
$$

Assim,

$$
\sum_{j: x_{j}\left(t_{a}\right)=1} a_{i, j}=\sum_{j: x_{j}\left(t_{a}\right)=1 \mathrm{e} x_{j}\left(t_{b}\right)=0} a_{i, j}+\sum_{j: x_{j}\left(t_{a}\right)=1 \mathrm{e} x_{j}\left(t_{b}\right)=1} a_{i, j}<0 .
$$

Analogamente, pela mudança de $x_{i}\left(t_{b}\right)=0$ para $x_{i}\left(t_{b}+1\right)=1$, temos que

$$
\sum_{j: x_{j}\left(t_{b}\right)=1} a_{i, j}=\sum_{j: x_{j}\left(t_{b}\right)=1 \mathrm{e} x_{j}\left(t_{a}\right)=0} a_{i, j}+\sum_{j: x_{j}\left(t_{b}\right)=1 \mathrm{e} x_{j}\left(t_{a}\right)=1} a_{i, j}>0 .
$$

\begin{tabular}{|c|c|c|}
\hline$x_{i}\left(t_{a}\right) \rightarrow x_{i}\left(t_{a}+1\right)$ & $x_{i}\left(t_{b}\right) \rightarrow x_{i}\left(t_{b}+1\right)$ & Restrições para $a_{i, j}$ \\
\hline $1 \rightarrow 0$ & $0 \rightarrow 1$ & $\sum_{j: x_{j}\left(t_{a}\right)=1 \mathrm{e} x_{j}\left(t_{b}\right)=0} a_{i, j}-\sum_{j: x\left(t_{b}\right)=1 \mathrm{e} x\left(t_{a}\right)=0} a_{i, j}<0$ \\
\hline $0 \rightarrow 1$ & $0 \rightarrow 0$ & $\underset{j: x_{j}\left(t_{a}\right)=1 \mathrm{e} x_{j}\left(t_{b}\right)=0}{-} a_{i, j}+\sum_{j: x\left(t_{b}\right)=1 \mathrm{e} x\left(t_{a}\right)=0} a_{i, j}<0$ \\
\hline $1 \rightarrow 1$ & $0 \rightarrow 0$ & $\underset{j: x_{j}\left(t_{a}\right)=1 \mathrm{e} x_{j}\left(t_{b}\right)=0}{-a_{i, j}}+\sum_{j: x\left(t_{b}\right)=1 \mathrm{e} x\left(t_{a}\right)=0} a_{i, j} \leq 0$ \\
\hline $0 \rightarrow 0$ & $0 \rightarrow 1$ & $\sum_{j: x_{j}\left(t_{a}\right)=1 \mathrm{e} x_{j}\left(t_{b}\right)=0} a_{i, j}-\sum_{j: x\left(t_{b}\right)=1 \mathrm{e} x\left(t_{a}\right)=0} a_{i, j}<0$ \\
\hline $0 \rightarrow 1$ & $1 \rightarrow 0$ & $\underset{j: x_{j}\left(t_{a}\right)=1 \mathrm{e} x_{j}\left(t_{b}\right)=0}{-\sum} a_{i, j}+\sum_{j: x\left(t_{b}\right)=1 \mathrm{e} x\left(t_{a}\right)=0} a_{i, j}<0$ \\
\hline $1 \rightarrow 1$ & $1 \rightarrow 0$ & $\underset{j: x_{j}\left(t_{a}\right)=1 \mathrm{e} x_{j}\left(t_{b}\right)=0}{-\sum} a_{i, j}+\sum_{j: x\left(t_{b}\right)=1 \mathrm{e} x\left(t_{a}\right)=0} a_{i, j}<0$ \\
\hline $0 \rightarrow 0$ & $1 \rightarrow 1$ & $\sum_{j: x_{j}\left(t_{a}\right)=1 \mathrm{e} x_{j}\left(t_{b}\right)=0} a_{i, j}-\sum_{j: x\left(t_{b}\right)=1 \mathrm{e} x\left(t_{a}\right)=0} a_{i, j} \leq 0$ \\
\hline $1 \rightarrow 0$ & $1 \rightarrow 1$ & $\sum_{j: x_{j}\left(t_{a}\right)=1 \mathrm{e} x_{j}\left(t_{b}\right)=0} a_{i, j}-\sum_{j: x\left(t_{b}\right)=1 \mathrm{e} x\left(t_{a}\right)=0} a_{i, j}<0$ \\
\hline
\end{tabular}

Agora, subtraindo as duas últimas desigualdades, temos

$$
\sum_{j: x_{j}\left(t_{a}\right)=1 \mathrm{e} x_{j}\left(t_{b}\right)=0} a_{i, j} \quad-\sum_{j: x_{j}\left(t_{b}\right)=1 \mathrm{e} x_{j}\left(t_{a}\right)=0} a_{i, j}<0 .
$$

Tabela 5.6: Restrições obtidas observando pares de transições $s\left(t_{a}\right) \rightarrow s\left(t_{a}+1\right)$ e $s\left(t_{b}\right) \rightarrow s\left(t_{b}+1\right)$. 


\subsubsection{Analisando as conexões entre os genes}

Para cada gene $x_{i}$ o algoritmo gera uma coleção de linhas consistentes $R_{i}=\left\{r_{i 1}, r_{i 2}, \ldots, r_{i m}\right\}$ usando as restrições geradas de acordo com as Proposições 1, 2 e 3. Um CSP solver pode ser utilizado para encontrar as soluções. Cada linha consistente $r_{i k}=\left(a_{i, 1}^{k}, a_{i, 2}^{k}, \ldots, a_{i, n}^{k}\right)$ possui $n$ entradas $a_{i, j}^{k}$, cada uma correspondendo a um tipo de conexão de entrada (inibição, ativação ou sem conexão) no gene $x_{i}$ a partir de $x_{j}$. Escolhendo uma linha para cada gene $x_{i}, i=1, \ldots, n$, podemos montar uma matriz consistente e analisar a frequência com que cada tipo de conexão aparece.

Formalmente, seja um par de genes $x_{i}$ e $x_{j}$. Sejam $\alpha_{i, j}, \beta_{i, j}$ e $\gamma_{i, j}$, a quantidade de vezes em que o gene $x_{j}$ ativa, não possui conexão e inibe $x_{i}$, respectivamente, considerando várias matrizes de regulação consistentes com os dados temporais. Podemos calcular a proporção com que $x_{j}$ ativa $x_{i}$ :

$$
\frac{\alpha_{i, j}}{\alpha_{i, j}+\beta_{i, j}+\gamma_{i, j}} .
$$

Analogamente, podemos calcular a proporção com que $x_{j}$ não possui conexão e inibe $x_{i}$.

Para analisar estas conexões, montamos um gráfico de barras (como em (Lau et al., 2007)), ilustrado na Fig. 5.3. Nesta figura, temos um pequeno exemplo contendo 6 genes: A, B, C, D, E e F. Na Fig. 5.3a estamos analisando as conexões de entrada do gene C. Cada tipo possível de conexão é denotado por uma cor: branco (ativação), cinza (sem conexão) e preto (inibição). Assim, podemos ver que o gene A, por exemplo, ativa o gene $\mathrm{C}$ em aproximadamente $1 / 3$ das soluções. O gene A também inibe ou não possui conexão com o gene $\mathrm{C}$ nesta mesma proporção. Analisando as conexões de entrada do gene E (Fig. 5.3b), percebemos que o gene A ativa E em $100 \%$ das soluções. Se todas as soluções consistentes possíveis forem geradas para montar o gráfico de barras, isso significa que uma aresta de ativação do gene A para o gene E deve estar presente em toda solução consistente. Este tipo de conexão é chamada de determinada. O mesmo acontece com os genes B e D na Fig. 5.3b (note que no caso do gene D, a "conexão" é determinada no sentido de que sabemos que D não interage com E). Quando uma barra apresenta apenas duas cores, como por exemplo, a barra do gene D na Fig. 5.3a, dizemos que a conexão é parcialmente determinada.

Para ajudar a validar os resultados, calculamos o rank das interações entre genes. Para um par de genes $x_{i}$ e $x_{j}$, o rank é definido por:

$$
\xi(i, j)=\xi(j, i)=\operatorname{inh}\left(x_{i} \leftarrow x_{j}\right)+\operatorname{act}\left(x_{i} \leftarrow x_{j}\right)+i n h\left(x_{j} \leftarrow x_{i}\right)+\operatorname{act}\left(x_{j} \leftarrow x_{i}\right),
$$

onde $\operatorname{inh}\left(x_{i} \leftarrow x_{j}\right)$ e $\operatorname{act}\left(x_{i} \leftarrow x_{j}\right)$ denotam a frequência estimada de inibição $\left(a_{i, j}=-1\right)$ e ativação $\left(a_{i, j}=1\right)$, respectivamente. Dessa maneira, o rank mede a frequência com que um par de genes está conectado nas soluções consistentes, levando em conta as duas direções (de $x_{i}$ para $x_{j}$ e vice-versa). A ideia é buscar na literatura (quando dados reais são utilizados) ou olhar a rede original (dados artificiais) pelas interações possuindo maior rank. 


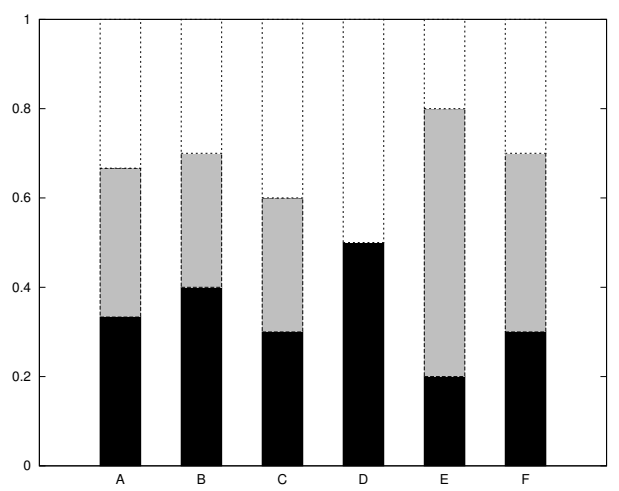

(a) Conexões de entrada - Gene $C$

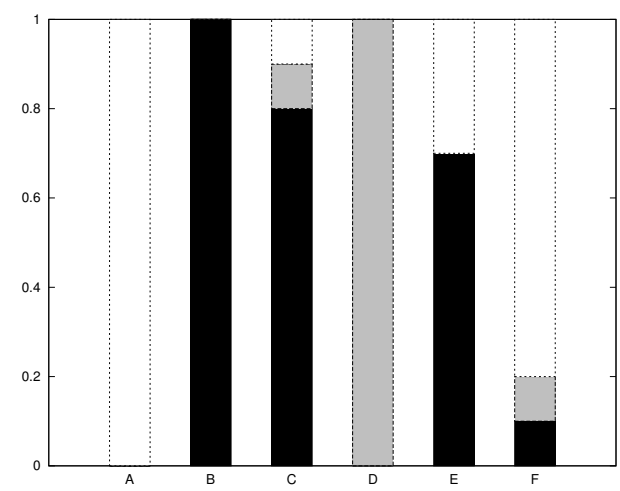

(b) Conexões de entrada - Gene E

Figura 5.3: Um exemplo de gráfico de barras mostrando a proporção das conexões de entradas nos genes C e E. Cada tipo possível de conexão é denotado por uma cor: branco (ativação), cinza (sem conexão) e preto (inibição).

\section{Resultados com dados artificiais}

Aplicamos esta metodologia em dados artificiais gerados pelo modelo de (Li et al., 2004). Utilizamos os estados da Tabela 3.2 como os dados temporais de expressão gênica para gerar as restrições do CSP. Para cada gene $x_{i}, i=1, \ldots, 11$, geramos todas as linhas consistentes. Assim, montamos todas as matrizes consistentes possíveis e analisamos as conexões, conforme as Fig. 5.4 e 5.5. Por estas figuras, detectamos 11 conexões determinadas e 13 parcialmente determinadas. Estas conexões são representadas na Fig. 5.6, onde as arestas em negrito representam as conexões determinadas. As arestas restantes representam as conexões parcialmente determinadas. Note que nesta figura não explicitamos o tipo de conexão, apenas a sua direção.

Usando as frequências das conexões, calculamos o rank (Eq. 5.23) e classificamos as interações. A Tabela 5.7 mostra os 10 maiores valores. Para validar os resultados, consideramos os 5, 10, 15, 20 e 25 maiores ranks, verificando quais conexões estão presentes na rede do ciclo celular da levedura (Fig. 3.2). Assim, calculamos a taxa de verdadeiro positivo, como mostra a Fig. 5.7. Podemos ver que, considerando os 25 maiores ranks, a taxa de verdadeiro positivo fica em torno de 0.75 .

\begin{tabular}{|c|c||c|}
\hline$x_{i}$ & $x_{j}$ & $\xi(i, j)$ \\
\hline \hline Clb5 & Mcm1 & 1.72 \\
Cln3 & SBF & 1.70 \\
Clb5 & Clb1 & 1.68 \\
Cln3 & MBF & 1.66 \\
Cln1 & Sic1 & 1.66 \\
Sic1 & Clb1 & 1.66 \\
Swi5 & Cdc20 & 1.65 \\
Clb1 & Mcm1 & 1.61 \\
Cdh1 & Clb1 & 1.55 \\
Cln1 & Cdh1 & 1.54 \\
\hline
\end{tabular}

Tabela 5.7: 10 maiores ranks usando dados artificiais. 


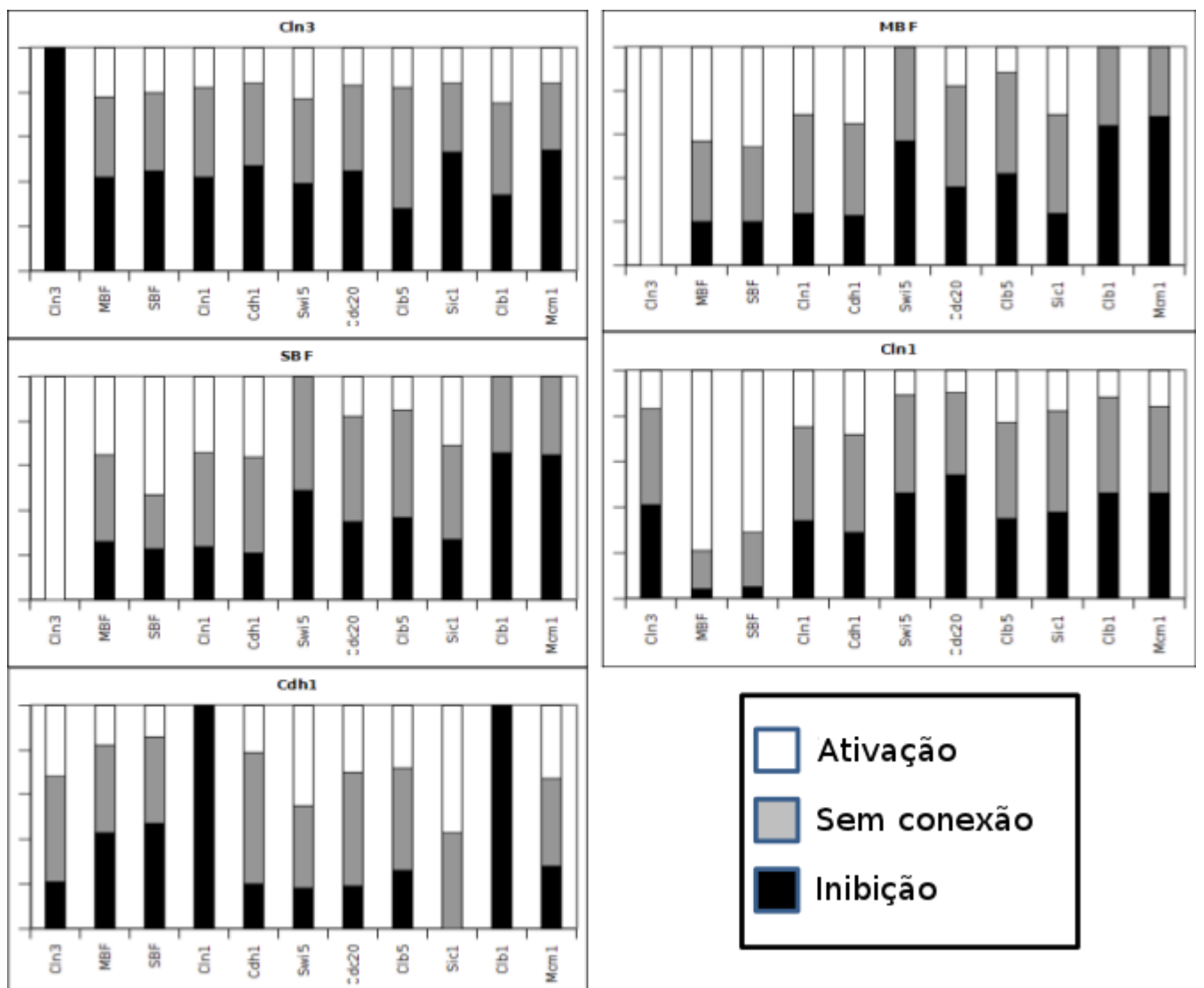

Figura 5.4: Gráfico de barras para os genes Cln3, MBF, SBF, Cln1 e Cdh1.

Discussão Observando as Fig. 5.4 e 5.5, podemos notar que em alguns casos, algumas barras onde as três possibilidades (ativação, sem conexão e inibição) são observadas, uma delas é muito pouco frequente. Este fato, juntamente com o fato de algumas conexões serem determinadas ou parcialmente determinadas, mostra que a via do ciclo celular restringe algumas conexões, e assim, restringe a rede como um todo. É importante observar que existe uma certa dependência entre as conexões. O conhecimento a priori de uma interação gênica pode enviesar outras conexões. Por exemplo, suponha que dois genes, A e B, tenham que produzir um input positivo em um gene $\mathrm{C}$, de acordo com as restrições impostas pelos dados. Se sabemos a priori que o gene A não interage com o gene $\mathrm{C}$, então o gene $\mathrm{B}$ deve possuir uma interação de ativação sobre o gene C. Sendo assim, é válido notar que não podemos simplesmente montar uma rede apenas selecionando as conexões mais frequentes para cada gene, pois esta rede pode não ser consistente com os dados. Apesar disso, as conexões determinadas e parcialmente determinadas podem ser utilizadas para guiar experimentos em wetlab. Com relação à validação através dos ranks, Fig. 5.7, as taxas de verdadeiro positivo são bastante satisfatórias.

\section{Resultados com dados biológicos}

Também aplicamos esta metodologia em dados biológicos de células HeLa, uma das linhagens celulares mais antigas e utilizadas em pesquisas (Rahbari et al., 2009). Estas células são derivadas de células de câncer cervical de uma mulher afro-americana chamada Henrietta Lacks, que morreu da doença em 1951. Nós utilizamos os dados disponibilizados por (Whitfield et al., 


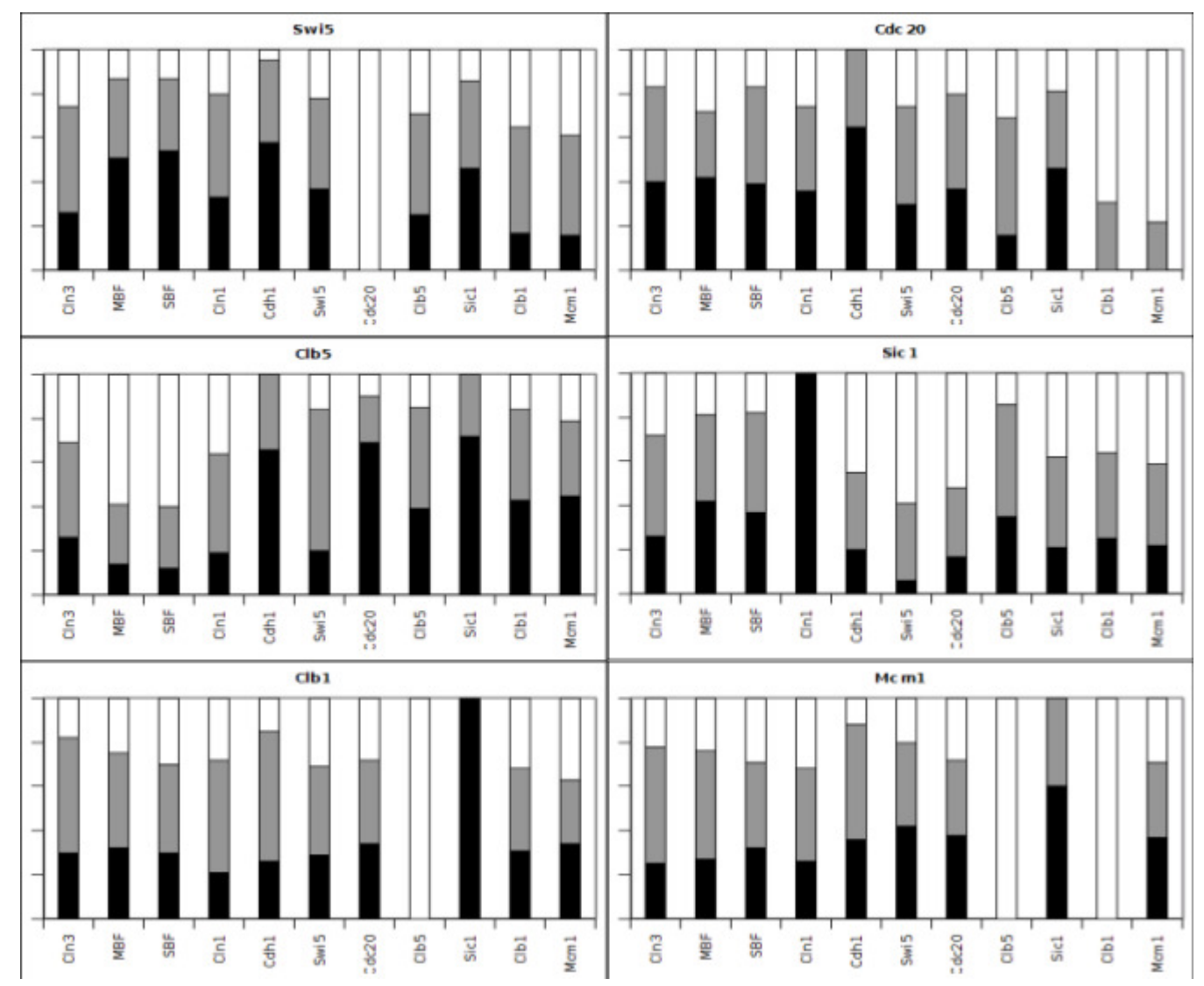

Figura 5.5: Gráfico de barras para os outros genes: Swi5, Cdc20, Clb5, Sic1, Clb1 e Mcm1.

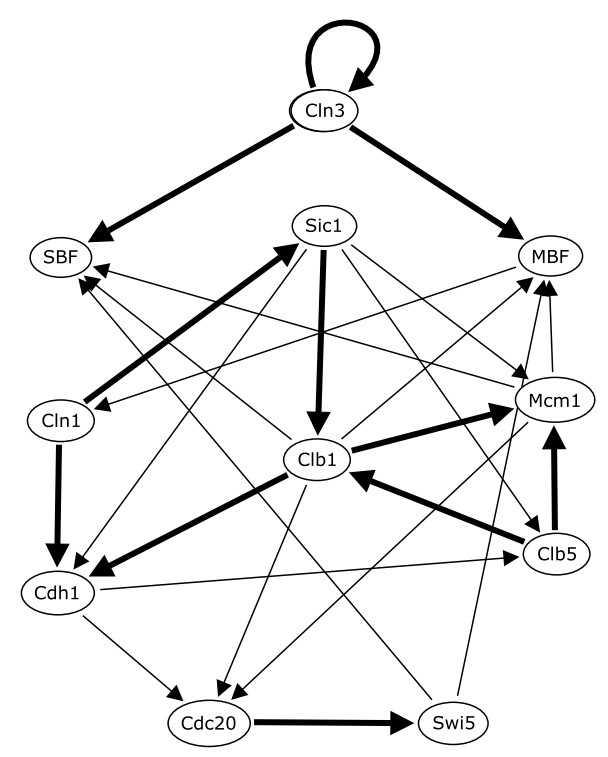

Figura 5.6: Conexões determinadas (negrito) e parcialmente determinadas. Note que a direção da seta não indica necessariamente ativação.

2002) onde a expressão gênica durante o ciclo celular foi caracterizado utilizando cDNA microarrays. Foi utilizado um dos cinco conjuntos de dados disponíveis, consistindo de 46 amostras e 20 genes. Estas 46 amostras correspondem a aproximadamente três ciclos; os 20 genes apresentam um "pico" na expressão gênica em determinada fase, de acordo com a Tabela 5.8. De acordo 


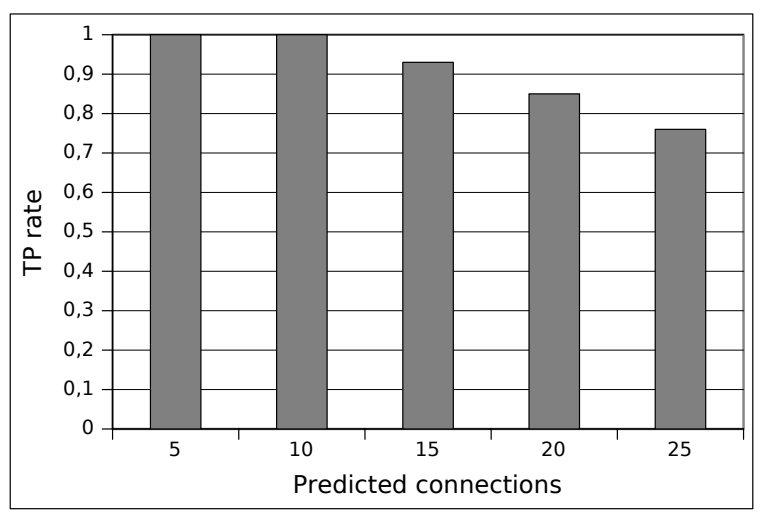

Figura 5.7: Taxa de verdadeiro positivo (TP rate) para os maiores ranks calculados. Levamos em conta os 5, 10, 15, 20 e 25 maiores ranks.

com (Whitfield et al., 2002), estes genes fazem parte da regulação do processo de ciclo celular. Para discretizar os dados, simplesmente calculamos, para cada gene $x_{i}$ a média da sua expressão gênica. Assim, se o valor da expressão gênica de um gene excede o valor da média, o seu valor final é 1 ; caso contrário é 0 .

\begin{tabular}{|c|l|}
\hline Fase & Genes \\
\hline \hline G1/S & CCNE1, E2F1, CDC6 e PCNA \\
\hline S & RFC4, DHFR, RRM2 e RAD51 \\
\hline G2 & CDC2, TOP2A, CCNF e CCNA2 \\
\hline G2/M & STK15, BUB1, CCNB1 e PLK \\
\hline M/G1 & PTTG1, RAD21, VEGFC e CDKN3 \\
\hline
\end{tabular}

Tabela 5.8: Os 20 genes cuja expressão gênica apresenta alta concentração durante determinada fase do ciclo celular.

Outro passo de pré-processamento foi necessário para dividir os dados em três, correspondendo aos três ciclos. Considerando os dados $S=\{s(1), s(2), \ldots, s(46)\}$, identificamos os vetores binários correspondentes aos atratores da rede. Por exemplo, os estados consecutivos $s(1), \ldots, s(5)$ são muito similares e nós os consideramos como um atrator de um único estado (singleton). A mesma abordagem foi tomada para as sequências de estados $s(16), s(17), s(18)$; $s(30), s(31), s(32)$ e $s(43), \ldots, s(46)$. Apesar de que estes estados binários consecutivos podem ser diferentes, assumimos que esta diferença é causada por ruídos nos dados.

Nós identificamos três ciclos celulares: $C_{1}=s(6), \ldots, s(17) ; C_{2}=s(19), \ldots, s(31)$ e $C_{3}=$ $s(33), \ldots, s(47)$. Sendo assim, para aplicar a metodologia, consideramos os ciclos separadamente. De acordo com (Whitfield et al., 2002), no terceiro ciclo, as células podem estar em fases diferentes, comprometendo o experimento. Portanto, utilizamos os ciclos $C_{1}$ e $C_{3}$.

Para cada gene $x_{i}$, foram geradas 10000 linhas consistentes, para cada ciclo. Para construir os gráficos de barras, utilizamos as soluções encontradas para os dois ciclos. Por exemplo, para o gene CDC2, o gráfico de barras é apresentado na Fig. 5.8. Os gráficos de todos os 20 genes podem ser vistos no Apêndice A.

Também realizamos um experimento, supondo que genes em uma fase só podem ser regulados por fases vizinhas, de acordo com a Tabela 5.8. Por exemplo, genes da fase G2/M não podem ser 


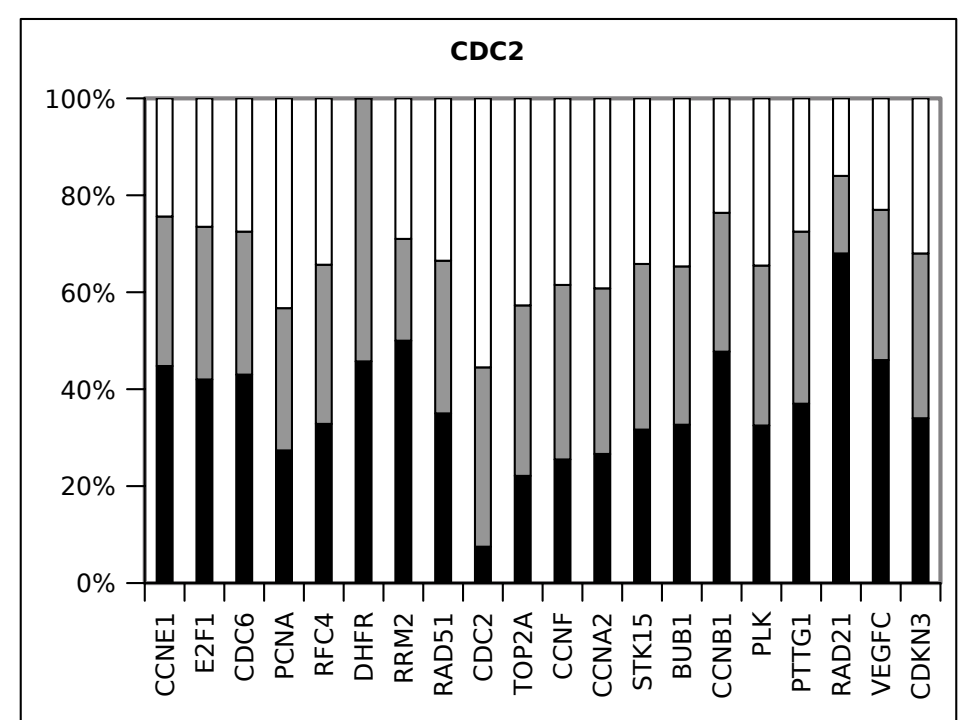

Figura 5.8: Gráfico de barras para as conexões de entrada do gene CDC2.

regulados pelos genes das fases G1/S e S. Assim, restringimos o espaço de busca das linhas consistentes. Algumas exceções são consideradas, por exemplo, permitimos que o gene CCNE1 seja regulado por qualquer outro gene, pois pela literatura este gene interage com um grande número de genes. Dizemos que neste experimento estamos inserindo algum "conhecimento biológico". Os gráficos são apresentados no Apêndice B.

Utilizando os gráficos de barras, calculamos os ranks das interações. As Tabelas 5.9 e 5.10 mostram os 10 maiores ranks, considerando e não considerando conhecimento biológico, respectivamente. Para algumas interações, foram encontradas referências na literatura, indicadas na última coluna de cada tabela.

\begin{tabular}{|c|c|c|l|}
\hline$x_{i}$ & $x_{j}$ & $\xi(i, j)$ & Referência bibliográfica \\
\hline \hline DHFR & TOP2A & 1.85 & \\
DHFR & RAD21 & 1.8 & \\
CCNE1 & CDC2 & 1.78 & Koff et al. (1992); Shanahan et al. (1999) \\
CCNE1 & CCNF & 1.75 & \\
RAD51 & STK15 & 1.75 & \\
BUB1 & PTTG1 & 1.75 & \\
RRM2 & CDC2 & 1.74 & Chan et al. (1999) \\
CDC2 & STK15 & 1.74 & \\
E2F1 & DHFR & 1.71 & Chiang et al. (1998); DeGregori et al. (1995) \\
CCNE1 & RAD51 & 1.69 & \\
\hline
\end{tabular}

Tabela 5.9: Os 10 maiores ranks calculados com os dados de células HeLa. Para algumas interações encontramos referências na literatura, como indicado na tabela.

Discussão Os resultados dos experimentos mostram que uma análise similar com relação aos dados artificiais também pode ser aplicada neste caso de células HeLa. Apesar de que, nenhuma conexão determinada foi detectada neste caso. Isso se deve ao número maior de genes e ao pouco número de amostras. Um número maior de amostras poderia gerar mais restrições para o 


\begin{tabular}{|c|c|c|l|}
\hline$x_{i}$ & $x_{j}$ & $\xi(i, j)$ & Referência bibliográfica \\
\hline \hline RRM2 & TOP2A & 2 & \\
RRM2 & CDC2 & 1.82 & \\
CDC2 & CCNF & 1.78 & Kong et al. $(2000)$ \\
CCNF & CCNA2 & 1.72 & \\
CCNE1 & CDC2 & 1.68 & Koff et al. $(1992) ;$ Shanahan et al. $(1999)$ \\
CDC2 & RAD21 & 1.68 & \\
CDC2 & PTTG1 & 1.68 & Holt et al. (2008) \\
TOP2A & CCNF & 1.67 & \\
DHFR & TOP2A & 1.66 & \\
PCNA & RFC4 & 1.66 & Cai et al. (1997); Ohta et al. (2002) \\
\hline
\end{tabular}

Tabela 5.10: Os 10 maiores ranks calculados com os dados de células HeLa, adicionando conhecimento biológico. Para algumas interações encontramos referências na literatura, como indicado na tabela.

CSP, fazendo com que mais conexões parcialmente determinadas ou até mesmo determinadas, surjam em um experimento similar. Como mencionamos no caso de dados artificiais, a introdução de algum conhecimento a priori também poderia restringir as conexões. Esta fato reforça a necessidade da participação/integração de biólogos especialistas durante o processo de inferência.

Esta abordagem apresentada para gerar linhas (e por sua vez, matrizes) consistentes é utilizada no algoritmo de inferência de redes baseado no paradigma de crescimento de semente. Este algoritmo é descrito a seguir.

\subsection{Algoritmo baseado em crescimento de semente}

Nesta seção iremos descrever o algoritmo de inferência proposto, baseado no paradigma de crescimento de semente de genes (Higa et al., 2011a). Como mencionamos anteriormente, uma semente é um pequeno conjunto de genes envolvidos em algum fenômeno biológico de interesse. Assim, desejamos agregar mais genes a este conjunto e inferir redes que sejam biologicamente interessantes, a partir de dados temporais de expressão gênica. Apesar do grande número de genes encontrados no genoma de um organismo, acreditamos que um pequeno subconjunto de genes é responsável por manter uma determinada função regulatória. Assim, o método visa inferir pequenas subredes de genes. O algoritmo possui dois passos principais: o passo de crescimento de semente e o passo de amostragem. No primeiro passo, adicionamos genes à semente, e no segundo, selecionamos algumas redes de acordo com alguns critérios que iremos apresentar mais adiante.

O modelo adotado é o de redes Booleanas com limiar e tomamos como entrada os dados temporais de expressão gênica e uma semente inicial. O passo de crescimento de semente pode ser visto como um problema de seleção de características, onde as características são os genes. Para calcular o valor da função critério para selecionar um gene, utilizamos a abordagem baseada em CSP descrita na seção anterior para gerar tBNs consistentes com os dados. Veremos mais adiante como esta função critério foi projetada. A saída do passo de crescimento é um subconjunto de genes, que serve como entrada para o passo de amostragem.

O algoritmo tem como saída um conjunto de redes, e não uma única rede. Assim, no passo de 
amostragem, devemos filtrar as redes seguindo algum critério. Em suma, estamos interessados em tBNs em que o número de atratores seja pequeno e que tenha uma bacia de atração predominante, como no modelo da levedura proposto por (Li et al., 2004). Apesar da ordem de execução dos passos (primeiro o crescimento e depois a amostragem), achamos que do ponto de vista do leitor é mais fácil compreender o algoritmo como um todo apresentando primeiro o passo de amostragem. Sendo assim, apresentaremos a seguir o passo de amostragem, o passo de crescimento de semente, e os resultados obtidos.

\subsubsection{Passo de amostragem}

Vamos supor que $X=\left\{x_{1}, x_{2}, \ldots, x_{n}\right\}$ é o conjunto de genes em estudo. A entrada para o passo de amostragem é uma série temporal $\mathbf{T}=\{s(1), s(2), \ldots, s(m)\}$ e um subconjunto $G=\left\{x_{i_{1}}, x_{i_{2}}, \ldots, x_{i_{\kappa}}\right\}$, onde $G \subseteq X$ (vamos assumir que $G$ é a saída do passo de crescimento de semente). Assim, uma tBN consistente formada pelos genes em $G$ é uma matriz de regulação $A$ de dimensão $\kappa \times \kappa$. Cada linha $r_{i}$ de $A$ é uma solução para o gene $x_{i}$. Assim, $r_{i}$ é um vetor tal que

$$
r_{i}=\left(a_{i, 1}, a_{i, 2}, \ldots, a_{i, \kappa}\right)
$$

onde $a_{i, j} \in\{-1,0,1\}$, para $j=1,2, \ldots, \kappa$.

Para cada gene $x_{i}$ podem existir várias linhas consistentes $r_{i}^{1}, r_{i}^{2}, \ldots, r_{i}^{m_{i}}$. Para gerar estas linhas, utilizamos a abordagem baseada em problemas de satisfação de restrições (CSP) apresentada na Seção 5.2. Dado que $x_{i}$ possui $m_{i}$ linhas consistentes, o número total de tBNs consistentes é $m_{1} \times m_{2} \times \cdots \times m_{\kappa}$. Assim, neste passo é feita uma amostragem destas redes, que são analisadas com relação a sua estrutura e dinâmica. Com relação à estrutura, verificamos a conectividade de entrada dos genes e o número de componentes conexas; e com relação à dinâmica, analisamos o número de atratores e o tamanho das bacias de atração.

\section{Conectividade e número de componentes conexas}

Como vimos na Seção 2.3, a conectividade $k_{i}$ de um gene $x_{i}$ é o número de genes tomados como entrada da função Booleana $f_{i}$. Em termos de matriz de regulação $A, k_{i}$ é o número de elementos não nulos na $i$-ésima linha. Dado isso, podemos considerar apenas linhas consistentes onde $a \leq k_{i} \leq b$, para $i=1, \ldots, \kappa$, onde $0<a \leq b$ são parâmetros inteiros denotando a conectividade mínima e máxima, respectivamente.

Uma das intuições de Kauffman era de que os atratores das redes Booleanas deveriam corresponder a tipos celulares, e é amplamente aceitável que sistemas complexos adaptáveis, tais como o genoma, operam na "fronteira do caos" (Shmulevich et al., 2002b). Simulações têm mostrado que redes Booleanas com baixa conectividade, especificamente, $k_{i}=2$, apresentam uma dinâmica entre o regime estável e caótico (Kauffman, 1993). Além disso, é biologicamente plausível esperar que uma proteína interage com um pequeno número de proteínas para realizar a sua função, com exceção de alguns genes (hub genes). Neste trabalho, utilizamos $a=2$ e $b=3$.

Para montar uma matriz (tBN), devemos selecionar uma linha consistente para cada gene $x_{i} \in G$, onde $a \leq k_{i} \leq b$. Além disso, deixamos em aberto a possibilidade de gerar redes 
possuindo um gene $h u b$. Aqui, um gene $h u b$ é um gene possuindo uma conectividade de saída alta, como nas redes scale-free (Barabási e Albert, 1999). A opção de gerar redes com um gene $h u b$ é especificada pelo usuário. Além disso, se existe um gene que já é conhecido como um gene $h u b$ na literatura, é possível defini-lo como o gene $h u b$ no passo de amostragem.

Outro ponto que levamos em consideração é o número de componentes conexas do grafo orientado induzido pela matriz de regulação $A$. Consideramos apenas grafos possuindo uma única componente conexa. Biologicamente, exigimos isto pois desejamos inferir uma pequena subrede de genes relacionados ao fenômeno em estudo, e não vários módulos de regulação.

\section{Atratores e bacias de atração}

O número total de tBNs consistente pode ser muito grande, mas estamos interessados em redes que podem ser biologicamente significantes. A questão é: como podemos identificar estas redes analisando a sua dinâmica? Para isso, estamos tomando o mesmo conceito encontrado em (Kauffman, 1993) e (Huang, 1999) (e outros trabalhos) onde é estabelecido que atratores estáveis são aqueles possuindo uma grande bacia de atração, e são formados por número pequeno de estados (por exemplo, atratores singletons). Apesar de que o espaço de estados de uma tBN pode ser grande, muitos estados não são biologicamente significantes. Por outro lado, os atratores podem representar tipos celulares ou estágios (diferenciação, proliferação, apoptose, etc.).

Para analisar uma tBN de acordo com seus atratores e suas bacias de atração, considere uma tBN selecionada a partir do espaço de redes consistentes, ou seja, uma matriz $A$. Sejam $\mathcal{A}_{1}, \mathcal{A}_{2}, \ldots, \mathcal{A}_{r}$ os atratores desta tBN com suas respectivas bacias de atração $\mathcal{B}_{1}, \mathcal{B}_{2}, \ldots, \mathcal{B}_{r}$. Denotamos por $\left|\mathcal{A}_{i}\right|\left(\left|\mathcal{B}_{i}\right|\right)$ o número de estados do atrator $\mathcal{A}_{i}$ (bacia $\mathcal{B}_{i}$ ). Dado isso, supondo que os estados são equiprováveis, a probabilidade de encontrar um estado arbitrário da rede em uma bacia $\mathcal{B}_{i}, i=1, \ldots, r$, é

$$
\mathrm{P}\left(Y_{i}=1\right)=\frac{\left|\mathcal{B}_{i}\right|}{\sum_{j=1}^{r}\left|\mathcal{B}_{j}\right|},
$$

onde $Y_{i}$ é uma variável aleatória binária denotando o fato de que um estado arbitrário se encontra na bacia $\mathcal{B}_{i}\left(Y_{i}=1\right)$. Com estas probabilidades, podemos calcular a seguinte entropia:

$$
H_{A}=-\sum_{i=1}^{r} \mathrm{P}\left(Y_{i}=1\right) \lg \left[\mathrm{P}\left(Y_{i}=1\right)\right] .
$$

A entropia (entropia de Shannon (Vajda et al., 1950)) é uma medida de incerteza associada à uma variável aleatória. Neste caso, a entropia atinge o valor máximo quando todas as bacias de atração possuem o mesmo tamanho. Desta maneira, estaremos buscando por redes possuindo apenas uma grande bacia de atração, ou seja, um valor baixo para a entropia.

\section{O algoritmo para a amostragem}

O algoritmo para realizar a amostragem de redes recebe como entrada o conjunto $G$ de genes, a série temporal $\mathbf{T}$, e os parâmetros $\mathcal{M}$ (número de redes a serem analisadas), $a$ e $b$ (conectividade de entrada mínima e máxima dos genes, respectivamente). Além disso, o usuário pode optar 
por selecionar redes contendo um gene $h u b$. Um passo de pré-processamento é necessário para encontrar as linhas consistentes para cada gene, usando a abordagem baseada em CSP. Assim, cada gene $x_{i} \in G$ possui um conjunto de linhas consistentes $R_{i}=\left\{r_{i}^{1}, r_{i}^{1}, \ldots, r_{i}^{m_{i}}\right\}$.

Com relação aos dados temporais $\mathbf{T}=\{s(1), \ldots, s(m)\}$, levamos em consideração que estes dados podem conter ruídos. Sendo assim, consideramos que uma perturbação pode ocorrer em algum instante de tempo $t$. Dessa maneira, um parâmetro $t$ é utilizado, onde $0 \leq t \leq m-1$, denotando que a transição de $s(t)$ para $s(t+1)$ foi causada por uma perturbação. O valor $t=0$ indica que não houve perturbação. Durante o passo de crescimento de semente, que iremos descrever mais adiante, veremos como um valor de $t$ é obtido; este valor é utilizado no passo de amostragem. Quando $t \neq 0$, dividimos os dados em $\mathbf{T}^{\prime}=\{s(1), \ldots, s(t)\}$ e $\mathbf{T}^{\prime \prime}=$ $\{s(t+1), \ldots, s(m)\}$. Assim, a rede tBN deve ser consistente com $\mathbf{T}^{\prime}$ e $\mathbf{T}^{\prime \prime}$, e é considerada uma tBN com perturbação.

Observando apenas a expressão dos genes em $G$, uma amostra em $t$ é um subvetor $s^{\prime}(t)=$ $\left[x_{i_{1}}(t), x_{i_{2}}(t), \ldots, x_{i_{\kappa}}(t)\right]$. Assim, é possível que uma sequência de transições $s^{\prime}(t) \rightarrow s^{\prime}(t+1) \rightarrow$ $\cdots \rightarrow s^{\prime}(t+\Delta t)$ esteja presente nos dados e que $s^{\prime}(t)=s^{\prime}(t+1)=\cdots=s^{\prime}(t+\Delta t)$. Neste caso, um passo de pré-processamento remove as amostras $s^{\prime}(t+1), \ldots, s^{\prime}(t+\Delta t)$ antes de gerar as soluções. Biologicamente, assumimos que esta sequência de transições ocorre pois no intervalo $t$ até $t+\Delta t$ não houve tempo suficiente para observarmos mudanças nas expressões dos genes em $G$, e esta sequência de estados repetidos não adicionam informação para o passo de amostragem.

A saída do algoritmo de amostragem é um conjunto de redes possuindo as entropias mais baixas. A quantidade de redes finais também pode ser um parâmetro para o algoritmo; em nossos experimentos, fixamos em $10 \%$ das redes possuindo os menores valores de entropia. O algoritmo pode ser descrito como segue:

Passo 0 : Para cada gene $x_{i} \in G$, encontre o conjunto de linhas consistentes $R_{i}$, considerando uma perturbação em $t$, se este for o caso;

Passo 1 : Monte uma matriz de regulação, selecionando uma linha consistente em $R_{i}$ para cada gene $x_{i} \in G$, de acordo com os parâmetros $a$ e $b$, e possivelmente selecionando um gene $h u b$;

Passo 2 : Se a tBN possui uma única componente conexa, vá para o Passo 3; caso contrário, vá para o Passo 1;

Passo 3 : Identifique os atratores da tBN; calcule a entropia;

Passo 4 : Se o número de redes analisadas for menor que $\mathcal{M}$, vá para o Passo 1; caso contrário, vá para o Passo 5;

Passo 5 : Selecione $10 \%$ das tBNs possuindo a menor entropia.

Como afirmado em (Higa et al., 2011b), uma desvantagem deste algoritmo é o Passo 0, que é exponencial no número de genes. Como estamos trabalhando com redes pequenas, o número de genes é pequeno, tornando possível a execução do algoritmo. No Passo 3, para identificar os atratores, a tBN deve ser simulada para que o diagrama de transição de estados possa ser construído. 
Este passo também é exponencial pois o número de estados da rede cresce exponencialmente com o número de genes. Este é o preço que deve ser pago para que seja feita uma análise da dinâmica da rede. A seguir, apresentamos o passo de crescimento de semente.

\subsubsection{Passo de crescimento de semente}

Nesta seção, iremos descrever como o conjunto de genes $G$, passado como entrada para o algoritmo de amostragem, é obtido. Uma semente $S=\left\{x_{i_{1}}, x_{i_{2}}, \ldots, x_{i_{k}}\right\}, S \subset X$, é um pequeno subconjunto de $k$ genes. De fato, estamos modelando a situação em que é conhecido que $x_{i_{1}}, x_{i_{2}}, \ldots, x_{i_{k}}$ participam do fenômeno biológico sendo estudado. O objetivo é identificar outros genes que interagem com os genes da semente e adicioná-los a um conjunto $Z$. Desta maneira, após o crescimento da semente, teremos um subconjunto $S \cup Z$ de genes. Este subconjunto é o conjunto $G$, passado para o algoritmo de amostragem.

Inicialmente o conjunto $Z$ é vazio. A cada passo do algoritmo de crescimento, selecionamos um gene candidato $x_{c} \in X-(S \cup Z)$ e o adicionamos a $Z$. Note que o conjunto $S$ nunca é alterado e o processo de crescimento para, uma vez que um certo número $d$ de genes é adicionado a $Z$. Assim, $d$ é um parâmetro do algoritmo. Após o crescimento da semente, esperamos ter um subconjunto $Z=\left\{x_{i_{k+1}}, x_{i_{k+2}}, \ldots, x_{i_{k+d}}\right\}$ de genes (pode ser que menos do que $d$ genes sejam adicionados). Alguns genes em $Z$ podem ter interações já conhecidas com os genes em $S$, ou mesmo com outros genes em $Z$. Outras interações podem ser verificadas em wetlab. Desta maneira, o algoritmo de inferência pode nos ajudar a realizar uma análise exploratória das interações gênicas.

O crescimento de semente pode ser visto como um problema de seleção de características. Assim, nós utilizamos o algoritmo de seleção de características improved forward floating selection (IFFS) (Nakariyakul e Casasent, 2009), apresentado na Seção 2.5.2. Neste contexto de seleção de características, a cada passo do algoritmo um gene candidato $x^{*} \in X-(S \cup Z)$ é selecionado tal que

$$
x^{*}=\underset{x_{c} \in X-(S \cup Z)}{\arg \max } J(c),
$$

onde $J(c)$ é o valor da função critério relativo ao gene candidato $x_{c}$. Na verdade, como iremos ver, o valor da função critério não depende somente de $x_{c}$, mas também de $S$, do conjunto atual de genes adicionados $Z$, e dos dados temporais T. Contudo, usamos $J(c)$ ao invés de $J(c, S, Z, \mathbf{T})$ para simplificar a notação. O gene candidato selecionado é aquele que provê uma boa variabilidade de tBNs para o passo de amostragem e uma baixa incerteza com relação as interações gênicas.

A função critério $J$ deve calcular uma pontuação para cada gene candidato $x_{c}$. Observando apenas a expressão gênica dos genes em $S \cup Z \cup\left\{x_{c}\right\}$, podemos gerar matrizes consistentes, ou seja, tBNs, e calcular uma pontuação baseada na variabilidade destas matrizes. Para projetar a função $J$, baseamos em três pontos: consistência dos dados, número de tBNs consistentes e entropia média destas soluções.

Nas subseções a seguir, consideramos uma série temporal $\mathbf{T}$ que serve como entrada para o algoritmo e supomos que $S=\left\{x_{i_{1}}, x_{i_{2}}, \ldots, x_{i_{k}}\right\}$ é a semente, e $Z=\left\{x_{i_{k+1}}, x_{i_{k+2}}, \ldots, x_{i_{k+l}}\right\}$, $l<d$, é o conjunto atual de genes adicionados (pode ser o caso inicial quando $Z$ é vazio). 


\section{Consistência dos dados}

A consistência com os dados garante que um gene candidato $x_{c}$, combinado com os genes em $S \cup Z$ podem gerar tBNs consistentes com relação aos dados T. Desta maneira, para um gene candidato arbitrário $x_{c}$, podemos gerar matrizes consistentes usando a mesma abordagem baseada em CSP, apresentada na Seção 5.2, considerando apenas os genes em $S \cup Z \cup\left\{x_{c}\right\}$. Dado que $|S|=k$ e $|Z|=l$, uma tBN é representada por uma matriz $A$ de dimensão $\ell \times \ell$, onde $\ell=k+l+1$.

Novamente, a desvantagem é que o número de matrizes possíveis cresce exponencialmente. $\mathrm{O}$ que enfatizamos aqui é que a semente é um conjunto pequeno de genes e adicionamos um gene por vez em $Z$, mantendo $\ell$ pequeno. Dado isso, para cada gene candidato, o algoritmo gera várias soluções contendo um pequeno número de genes. Nós consideramos apenas as tBNs consistentes e calculamos uma pontuação baseada no número de soluções e na entropia média destas soluções, como mostramos a seguir.

\section{Número de tBNs consistentes}

A função critério leva em consideração o número de matrizes consistentes geradas ao adicionar $x_{c}$ a $Z$. Um gene que, se adicionado, gera uma grande variabilidade de soluções, têm preferência sobre os genes que geram poucas soluções. Biologicamente, esta variabilidade é importante devido aos complexos mecanismos de regulação, muitas vezes desconhecidos, que fazem parte de organismo. Por exemplo, fatores de transcrição podem atuar sozinhos ou com outras proteínas para realizarem suas funções (Roeder, 1996). Uma proteína pode agir ativando um gene em uma situação, e inibindo em outra. Outro fato é que uma proteína pode se dobrar (folding), tomando uma forma tridimensional específica, definindo a sua função (Alberts et al., 2007). Neste passo de crescimento de semente, procuramos manter esta variabilidade de mecanismos regulatórios, deixando a tarefa de selecionar as redes que possam ser interessantes para o passo de amostragem.

No passo de crescimento de semente, também levamos em consideração a conectividade mínima (a) e máxima $(b)$ de cada gene em $S \cup Z \cup\left\{x_{c}\right\}$, como no passo de amostragem. Também utilizamos $a=2$ e $b=3$. Um parâmetro $\eta$ também é utilizado, onde $\eta>0$. Este parâmetro indica quando considerar ou não a conectividade mínima e máxima. Enquanto $\ell<\eta$, consideramos qualquer solução, independente da conectividade. Em geral, $\eta$ é um valor baixo e foi introduzido pois quando $\ell$ é pequeno pode ser difícil encontrar soluções com a conectividade limitada. Assim, no começo do processo de crescimento, pode ser que o algoritmo não leve em consideração a conectividade mínima e máxima de entrada dos genes. Depois de adicionar um certo número de genes, teremos $\ell \geq \eta$, e então o algoritmo passa a considerar os parâmetros $a$ e $b$. Obviamente, quando $k$ (tamanho da semente inicial) é grande o suficiente, $\eta$ perde a sua utilidade. Neste trabalho, usamos $\eta=5$.

Dado que cada gene $x_{i} \in S \cup Z \cup\left\{x_{c}\right\}$ pode ter $m_{i}$ linhas consistentes, tomando uma linha para cada gene, montamos uma matriz de regulação $A$. O número total de matrizes consistentes 


$$
\delta_{c}=\prod_{i=1}^{\ell} m_{i}
$$

O número máximo de matrizes (consistentes ou não) é $3^{\ell^{2}}$. Quando $\ell \geq \eta$, consideramos apenas soluções onde cada linha $r_{i}=\left(a_{i, 1}, \ldots, a_{i, \ell}\right)$ da matriz possui conectividade $k_{i}, a \leq k_{i} \leq b$. Neste caso, cada linha possui $2^{j}\left(\begin{array}{l}\ell \\ j\end{array}\right)$ configurações possíveis, para $j=a, a+1, \ldots, b$. Portanto, definimos o número máximo de matrizes para um conjunto $S \cup Z \cup\left\{x_{c}\right\}$ por

$$
\Delta_{c}= \begin{cases}3^{\ell^{2}}, & \text { se } \ell<\eta \\
\sum_{j=a}^{b}\left[2^{j}\left(\begin{array}{l}
\ell \\
j
\end{array}\right)\right]^{\ell}, & \text { caso contrário }\end{cases}
$$

Assim, definimos a proporção de soluções consistentes por

$$
\mathcal{P}(c)= \begin{cases}0, & \text { se } \delta_{c}=0 \\ \lg \delta_{c} / \lg \Delta_{c}, & \text { caso contrário } .\end{cases}
$$

onde lg é o logaritmo na base 2, utilizado apenas para evitar valores muito pequenos pois $\Delta_{c} \gg \delta_{c}$. Note que, quando $\delta_{c}=1$ temos $\mathcal{P}(c)=0$, como no caso em que $\delta_{c}=0$. Dessa maneira, quando apenas uma solução é encontrada é tão ruim quanto no caso em que nenhuma solução é encontrada. Vale a pena notar que para dois genes candidatos $x_{c_{1}}$ e $x_{c_{2}}$, temos $\Delta_{c_{1}}=\Delta_{c_{2}}$ quando ambos estão competindo para serem adicionados a $Z$. O algoritmo tende a favorecer genes possuindo valores mais altos de $\mathcal{P}(c)$.

\section{Entropia média das soluções}

A entropia também é utilizada neste passo, mas relacionada a outra variável aleatória. Utilizando as soluções consistentes geradas pelos genes em $S \cup Z \cup\left\{x_{c}\right\}$, podemos calcular a entropia destas soluções. A entropia média mede a incerteza das conexões entre os genes, de uma maneira global. Por exemplo, considere um par de genes $x_{i}$ e $x_{j}$. Se uma aresta de ativação de $x_{i}$ para $x_{j}$ está presente em toda solução consistente, então não há incerteza com relação a esta aresta. No caso oposto, quando a consistência é obtida com $x_{i}$ ativando, inibindo ou sem conexão com $x_{j}$, a incerteza é alta. Do ponto de vista de alguém que esteja tentando inferir relações gênicas, um nível de incerteza baixo pode ser desejável.

Quando a incerteza é baixa, o número total de soluções tende a ser baixo também. Suponha que para um dado conjunto $S \cup Z \cup\left\{x_{c}\right\}$ exista apenas uma única solução consistente (é claro que esta situação é pouco provável). Neste caso, não há incerteza (menor entropia possível) e o gene candidato seria considerado um bom gene a ser adicionado. Por outro lado, isto implica que não há uma certa variabilidade de soluções, desejável no passo de amostragem. Por esta razão, veremos que a função critério é projetada para prover ao usuário uma maneira de buscar por um balanço entre a proporção de soluções consistentes e a entropia média.

Seja $x_{i}, x_{j} \in S \cup Z \cup\left\{x_{c}\right\}$ um par de genes e suponha que todas linhas consistentes foram geradas para o gene $x_{i}$ (considerando a conectividade mínima e máxima, se for o caso). Sejam 
$\alpha_{i, j}(c), \beta_{i, j}(c)$ e $\gamma_{i, j}(c)$ a quantidade de vezes em que $x_{j}$ ativa, não possui conexão e inibe $x_{i}$, respectivamente, considerando as linhas consistentes de $x_{i}$ (como no gráfico de barras da Fig. 5.3). Se usarmos uma variável aleatória discreta $X_{i, j}$ com possíveis valores em $\{-1,0,1\}$ para denotar a conexão de $x_{j}$ para $x_{i}$, podemos calcular a seguinte probabilidade

$$
\mathrm{P}\left(X_{i, j}=1\right)=\frac{\alpha_{i, j}(c)}{\alpha_{i, j}(c)+\beta_{i, j}(c)+\gamma_{i, j}(c)} .
$$

Similarmente, podemos calcular $\mathrm{P}\left(X_{i, j}=0\right)$ e $\mathrm{P}\left(X_{i, j}=-1\right)$. Assim, é possível calcular a entropia

$$
H\left(X_{i, j}\right)=-\sum_{\lambda} \mathrm{P}\left(X_{i, j}=\lambda\right) \lg \left(\mathrm{P}\left(X_{i, j}=\lambda\right)\right),
$$

onde $\lambda \in\{-1,0,1\}$ e lg é o logaritmo na base 2 . Neste caso, $H\left(X_{i, j}\right) \leq-\lg (1 / 3)$, e o valor máximo é atingido quando $\alpha_{i, j}(c)=\beta_{i, j}(c)=\gamma_{i, j}(c)$. Como desejamos maximizar a pontuação para o gene que minimiza a entropia, tomamos a média de $-\lg (1 / 3)-H\left(X_{i, j}\right)$ sobre todos os genes $x_{j}$ :

$$
H_{i}=\frac{1}{\ell} \sum_{j}-\left[\lg (1 / 3)+H\left(X_{i, j}\right)\right]
$$

Finalmente, a entropia média é calculada por

$$
\mathcal{H}(c)=\frac{1}{\ell} \sum_{i} H_{i}
$$

que mede o nível de incerteza das soluções de uma maneira global.

\section{Função critério}

A função critério para avaliar um gene candidato $x_{c}$ é baseada nas medidas $\mathcal{P}(c)$ e $\mathcal{H}(c)$ :

$$
J(c)=\omega \mathcal{P}(c)+(1-\omega) \mathcal{H}(c),
$$

onde $0 \leq \omega \leq 1$ é um fator de balanço entre $\mathcal{P}(c)$ e $\mathcal{H}(c)$. Se usarmos $\omega=1$, então o algoritmo sempre irá adicionar o gene candidato que gera o maior número de soluções. Por outro lado, $\omega=0$ irá favorecer genes possuindo baixa incerteza, não importando a quantidade de soluções. Neste trabalho, utilizamos $\omega=0.5$. Desta maneira, a função critério é projetada para selecionar um gene candidato que provê uma certa variabilidade de soluções, enquanto mantém o nível de incerteza razoavelmente baixo.

\section{O algoritmo de crescimento de semente}

O algoritmo de crescimento de semente é baseado no algoritmo IFFS (Seção 2.5.2). O algoritmo tenta encontrar um gene para adicionar (SFS), remover (SBS) ou substituir (Replace), primeiramente sem considerar uma perturbação nos dados T. Se $J(c)=0$ para todo gene candidato, ou seja, nenhum deles juntamente com os genes em $S \cup Z$ provê soluções consistentes, então o algoritmo busca novamente, desta vez considerando que uma única perturbação ocorreu 
em T, em algum instante de tempo. Assim, o algoritmo considera um perturbação em $t$, para $t=1, \ldots, m-1$. O algoritmo calcula o valor da função critério para cada valor de $t$, e o maior valor é utilizado para avaliar o gene candidato $x_{c}$. Se nenhuma solução consistente for encontrada para os genes candidatos, o algoritmo é encerrado. Note que consideramos apenas uma única perturbação na série temporal. Como em geral a quantidade de amostras é pequena, considerar que várias transições foram causadas por perturbações seria o mesmo que considerar que os dados são muito ruidosos. Como no passo de amostragem, também é realizado um pré-processamento para remover os estados consecutivos repetidos, quando observamos apenas os genes em $S \cup Z \cup\left\{x_{c}\right\}$.

A entrada do algoritmo é a série temporal $\mathbf{T}$ e a semente inicial $S$. Além disso, também devem ser configurados os parâmetros $a, b, \eta$ e $\omega$. O algoritmo pode ser descrito em passos, como segue:

Passo $0: Z \leftarrow \emptyset$;

Passo 1 : (SFS) Encontre o melhor gene candidato $x^{*}$ usando o algoritmo SFS. Se nenhum candidato for encontrado, vá para o Passo 4. Caso contrário, faça $Z \leftarrow Z \cup\left\{x^{*}\right\}$, e se $|Z|=d$, vá para o Passo 4 ;

Passo 2 : (SBS) Usando o método SFS, encontre o gene menos significante $\bar{x}$ em $Z$ e verifique se removendo ele resulta em um melhor conjunto de tamanho $|Z|-1$. Se sim, faça $Z \leftarrow Z-\{\bar{x}\}$ e repita o Passo 2. Caso contrário, vá para o Passo 3;

Passo 3 : (Replace) Substitua cada gene em $Z$ por cada gene candidato possível. Se a melhor substituição resulta em uma pontuação maior do que a atual, então substitua o gene fraco (característica fraca) pelo melhor gene encontrado, e vá para o Passo 2. Caso contrário, vá para o Passo 1;

Passo 4 : Retorne o conjunto $S \cup Z$.

Nos Passos 1, 2 e 3, devemos lembrar que existe um pré-processamento dos dados de entrada, antes de calcular o valor da função critério, para cada gene candidato. Este algoritmo segue o fluxograma da Fig. 2.11. Ao final de sua execução, esperamos obter um subconjunto $S \cup Z$ de $k+d$ genes, que é passado como entrada para o passo de amostragem. Com relação ao parâmetro $t$ do passo de amostragem, se o último gene adicionado a $Z$ foi considerando que uma perturbação ocorreu no instante $t$, este valor é utilizado no passo de amostragem. Caso contrário, utilizamos $t=0$.

\subsubsection{Resultados}

Aplicamos o algoritmo de inferência nos mesmos dados artificiais e biológicos citados na Seção 5.2. Para validar o algoritmo, utilizamos a rede conhecida (ground truth) no caso dos dados artificiais do ciclo celular da levedura; no caso biológico de células HeLa, buscamos por referências na literatura a respeito das interações gênicas encontradas. Antes de apresentar os resultados, falaremos um pouco a respeito da implementação do algoritmo. 


\section{Implementação}

O passo de crescimento de semente foi implementado separadamente do passo de amostragem. Apesar disso, ambos foram implementados em linguagem $\mathrm{C}++$, por uma questão de desempenho na execução dos algoritmos. Como mencionamos na Seção 2.6, existem CSP solvers que fazem a busca por soluções de um problema de satisfação de restrições. Nós utilizamos uma biblioteca chamada Gecode ${ }^{2}$ (generic constraint development enviroment) (Tack, 2009). O Gecode tem vencido todas as edições (2008 a 2011) de uma competição conhecida como MiniZinc Challenge, que visa avaliar CSP solvers. Uma característica do Gecode é que ele pode utilizar todos os processadores de uma máquina de maneira transparente para o usuário, o que é importante para o nosso problema uma vez que realizamos uma busca intensiva por soluções do CSP, principalmente no passo de crescimento de semente.

No passo de amostragem, o ponto crítico é o cálculo da entropia (Eq. 5.26), pois para isso devemos simular a tBN e construir o diagrama de transição de estados. Utilizamos a biblioteca pthreads (POSIX threads) que provê uma API (application programming interface) para a criação e manipulação de threads. Assim, em uma máquina com $N$ processadores, podemos simular $N$ tBNs simultaneamente.

\section{Dados artificiais}

Realizamos alguns experimentos com dados artificiais do ciclo celular da levedura. Tomamos a série temporal da Tabela 3.2 como os dados de entrada. Em um dos experimentos, iniciamos com uma semente $S=\{\mathrm{Cdc} 20, \mathrm{Clb} 1\}, d=4$ (número de genes a serem adicionados) e $\mathcal{M}=1000$ (número de redes a serem observadas no passo de amostragem). Consideramos primeiro um experimento em que um gene $h u b$ foi selecionado aleatoriamente. Após o passo de crescimento de semente obtivemos o subconjunto $Z=\{\mathrm{Cln} 3, \mathrm{MBF}, \mathrm{Clb} 5, \mathrm{Cdh} 1\}$. Assim, $1000 \mathrm{tBNs}$ foram geradas aleatoriamente, contendo estes 6 genes, e a entropia (Eq. 5.26) foi calculada para cada uma. Na Fig. 5.9 temos o histograma das entropias calculadas. Destas redes, as 100 possuindo a menor entropia foram consideradas como a saída do algoritmo. O menor valor encontrado foi 0.08 , entre as 96 redes de menor entropia. Para as 100 redes, foi calculada a matriz de confusão (Tabela 5.11), onde tomamos a rede conhecida da Fig 3.2 como ground truth.

\begin{tabular}{c|c|c}
\hline Aresta & Inferida & Não inferida \\
\hline \hline Presente em GT & TP & FN \\
\hline Ausente em GT & FP & TN \\
\hline
\end{tabular}

Tabela 5.11: Matriz de confusão. $T P=$ verdadeiro positivo, $F N=$ falso negativo, $F P=$ falso positivo and $T N=$ verdadeiro negativo. GT é a rede ground truth.

Em seguida, calculamos a taxa de verdadeiro positivo (TPR) e a taxa de falso positivo (FPR), definidas por

$$
\mathrm{TPR}=\frac{\mathrm{TP}}{\mathrm{TP}+\mathrm{FN}} \text { e } \mathrm{FPR}=\frac{\mathrm{FP}}{\mathrm{FP}+\mathrm{TN}}
$$

\footnotetext{
${ }^{2}$ www.gecode.org
} 


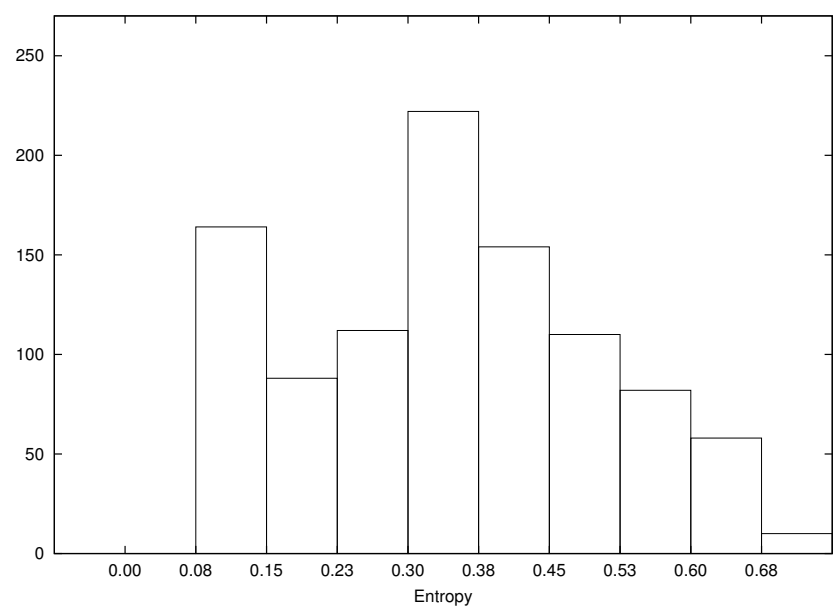

Figura 5.9: Histograma das entropias calculadas, considerando um gene hub aleatório, para os dados artificiais.

Marcamos os pontos (FPR, TPR) em um espaço ROC (receiver operating characteristic), como mostra a Fig. 5.10. Os pontos mais próximos de $(0,1)$ representam as melhores redes em termos de TPR e FPR. Muitos pontos estão sobrepostos, e existem dois pontos sobrepostos representando as duas melhores redes. Apresentamos uma delas, correspondendo à matriz de confusão da Tabela 5.12, na Fig. 5.11, onde os nós em diamante representam os genes da semente inicial. Arestas sólidas são aquelas que estão de acordo com a rede ground truth. Como podemos ver, as interações entre os genes de $S$ foram recuperadas, relembrando que os genes da semente inicial representam um pequeno subconjunto onde é conhecido que eles interagem em algum fenômeno biológico. Para esta rede, temos FPR $=0.24$ e TPR $=0.82$. O correspondente diagrama de transição de estados é mostrado na Fig. 5.12, onde cada ponto denota um estado, e uma aresta de um ponto a outro denota a transição de acordo com o modelo tBN. Neste diagrama temos $2^{6}=64$ estados onde o ponto preto denota o estado atrator (singleton, neste caso) possuindo a maior bacia de atração (63 estados). A via do ciclo celular representada pelos dados $\mathbf{T}$ é denotado pelo caminho em negrito. Vale a pena notar que este caminho possui menos estados do que temos nos dados $\mathbf{T}$. Isto ocorre devido ao pré-processamento que remove estados repetidos de $\mathbf{T}$ quando observamos apenas os genes em $S \cup Z$.

\begin{tabular}{c|c|c}
\hline Aresta & Inferida & Não inferida \\
\hline \hline Presente em GT & 9 & 2 \\
\hline Ausente em GT & 6 & 19 \\
\hline
\end{tabular}

Tabela 5.12: A matriz de confusão da rede apresentada na Fig. 5.11.

Podemos ver o diagrama da Fig. 5.12 como uma versão reduzida do diagrama da Fig. 3.3. Esta via representa as fases do ciclo celular, onde o atrator representa o estado $\mathrm{G}_{1}$ estacionário. Este atrator é o vetor binário (001000) e o primeiro estado da via é o vetor (101000). A única diferença entre estes dois estados é o gene mais à esquerda, que corresponde ao Cln3. Assim como afirmado em (Li et al., 2004), a célula se mantém no estado $\mathrm{G}_{1}$ estacionário (001000) esperando por outra rodada de divisão celular. Quando há uma concentração suficiente da proteína Cln3, 


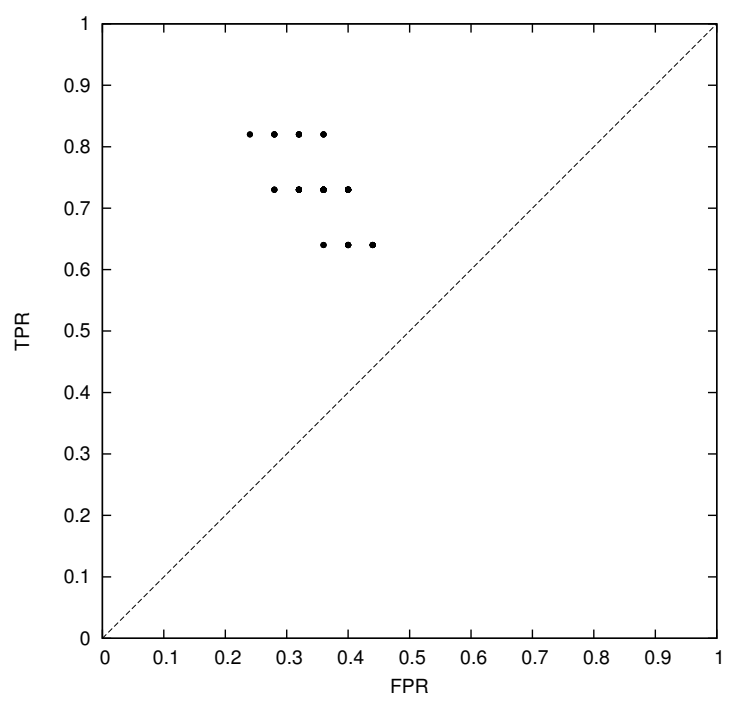

Figura 5.10: $O$ espaço ROC para o experimento com dados artificiais, considerando um gene hub selecionado aleatoriamente. Há 100 pontos neste espaço, mas muitos deles estão sobrepostos. Os pontos mais próximos de $(0,1)$ representam as melhores redes em termos de TPR e FPR.

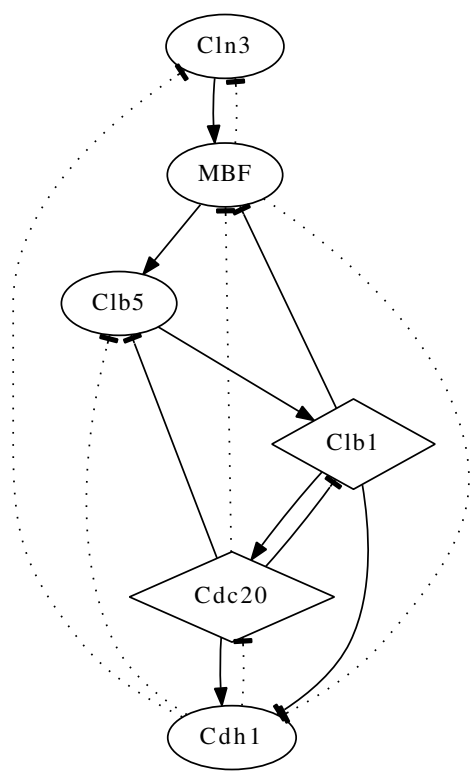

Figura 5.11: Rede inferida pelo algoritmo representada por um dos melhores pontos no espaço ROC da Fig. 5.10. Os nós em diamante são os genes da semente inicial. O gene Cdh1 foi selecionado aleatoriamente como um gene hub. As arestas sólidas são aquelas que estão de acordo com a rede ground truth. Esta figura foi feita com a ferramenta Graphviz (Ellson et al., 2002).

o processo de divisão é iniciado, e é por isso que no primeiro estado da via, (101000), o valor do gene Cln3 é 1 . Também vale notar que o caminho em negrito é contínuo, o que significa que a consistência foi atingida sem a necessidade de considerar uma perturbação em T. Para este experimento, os valores médios (considerando as 100 redes) de FPR e TPR são 0.36 e 0.73, respectivamente.

Em um segundo experimento, não consideramos um gene $h u b$, apenas a conectividade $k_{i}$, onde $2 \leq k_{i} \leq 3$. O histograma das entropias é apresentado na Fig. 5.13. O menor valor encontrado foi 0.098 entre 98 redes. Realizando a análise do espaço ROC, selecionamos a rede apresentada 


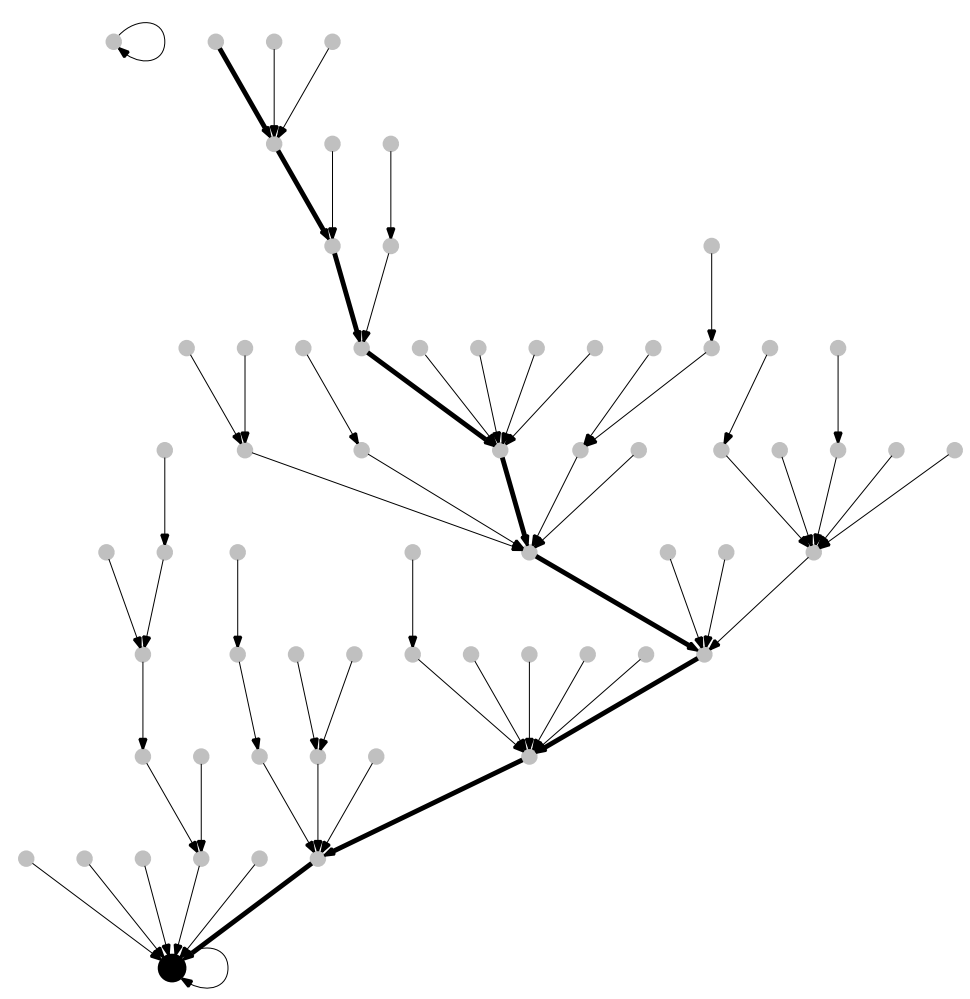

Figura 5.12: O diagrama de transição de estados da rede da Fig. 5.11. O caminho em negrito denota a via dada pela série temporal. O ponto preto denota o estado atrator. Esta figura também foi feita com a ferramenta Graphviz (Ellson et al., 2002).

na Fig. 5.14, e sua correspondente matriz de confusão é apresentada na Tabela 5.13. Esta rede é parecida com a rede da Fig. 5.11 e, comparando o seu diagrama de transição de estados (Fig. 5.15) com o diagrama da Fig. 5.12, podemos notar resultados similares com relação à via do ciclo celular. Neste experimento, os valores médios de FPR e TPR são 0.37 e 0.71, respectivamente. Na Tabela 5.14, resumimos alguns outros resultados com relação aos valores FPR e TPR.

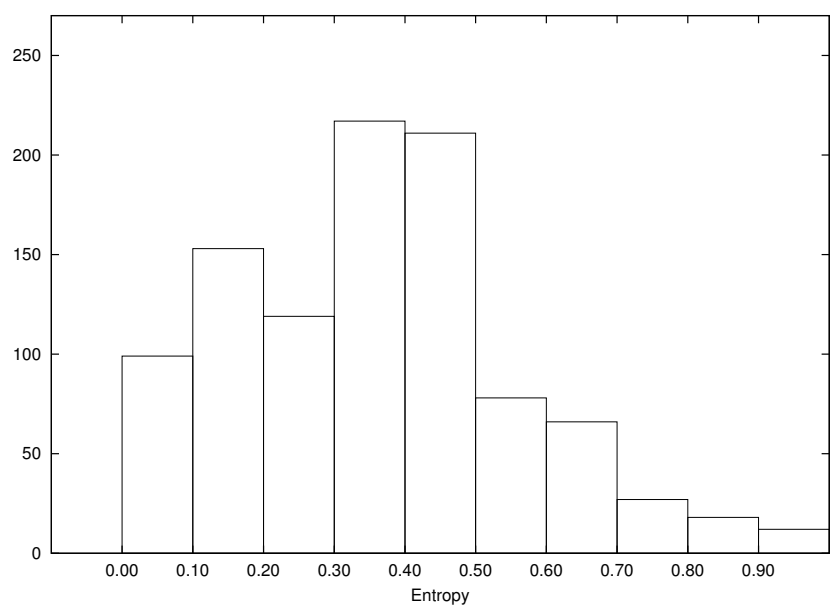

Figura 5.13: Histograma das entropias calculadas sem considerar um gene hub, para os dados artificiais. 


\begin{tabular}{c|c|c}
\hline Aresta & Inferida & Não inferida \\
\hline \hline Presente em GT & 10 & 2 \\
\hline Ausente em GT & 5 & 19 \\
\hline
\end{tabular}

Tabela 5.13: Matriz de confusão da rede da Fig. 5.14.

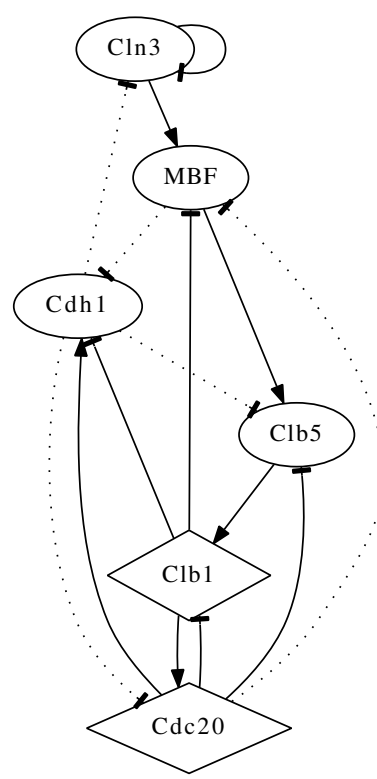

Figura 5.14: Rede inferida sem considerar um gene hub. Para esta rede temos $\mathrm{FPR}=0.21$ e TPR $=$ 0.83 .

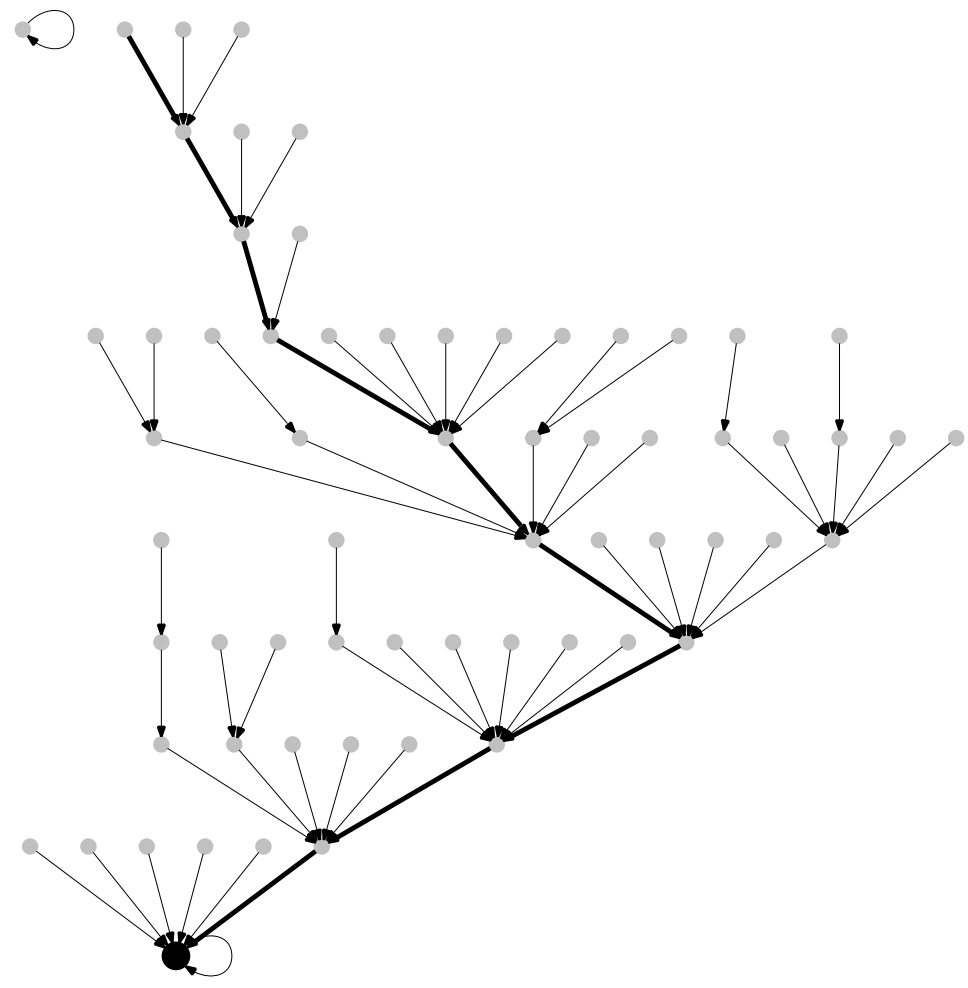

Figura 5.15: Diagrama de transição de estados da rede da Fig. 5.14. 


\begin{tabular}{c|c|c|c|c|c}
\hline$S$ & $Z$ & FPR (hub) & TPR (hub) & FPR & TPR \\
\hline \hline MBF, SBF & Cln3, Swi5, Cdc20, Clb1 & 0.36 & 0.75 & 0.36 & 0.75 \\
\hline MBF, Clb5 & Cln3, Cln1, Swi5, Cdc20 & 0.42 & 0.75 & 0.42 & 0.75 \\
\hline Cln1, Sic1 & Cln3, MBF, Cdh1, Swi5 & 0.44 & 0.75 & 0.42 & 0.75 \\
\hline Swi5, Mcm1 & Cln3, MBF, Cln1, Cdh1 & 0.43 & 0.86 & 0.41 & 0.82 \\
\hline
\end{tabular}

Tabela 5.14: Tabela resumindo alguns resultados com relação a FPR e TPR. S é a semente inicial e Z o conjunto de genes adicionados. Para cada semente, dois experimentos foram realizados: com e sem um gene hub aleatório. Os valores de FPR e TPR são médias calculadas a partir das 100 redes possuindo os menores valores de entropia.

\section{Dados biológicos}

Também aplicamos o algoritmo em dados biológicos de células HeLa. Utilizamos um dos cinco experimentos providos por (Whitfield et al., 2002), denominado "Thy-Thy 3", consistindo de 46 amostras representando aproximadamente três ciclos celulares. Cada fase do ciclo foi estimada através de citometria de fluxo, e nós utilizamos o primeiro ciclo, composto de 12 amostras. Estes dados foram discretizados em dois níveis com o algoritmo Bikmeans (Seção 2.1.1). Os dados discretizados são apresentados na Tabela 5.15.

\begin{tabular}{c||cccccccccccccccccccc}
\hline$t$ & $\mathbf{A}$ & $\mathbf{B}$ & $\mathbf{C}$ & $\mathbf{D}$ & $\mathbf{E}$ & $\mathbf{F}$ & $\mathbf{G}$ & $\mathbf{H}$ & $\mathbf{I}$ & $\mathbf{J}$ & $\mathbf{K}$ & $\mathbf{L}$ & $\mathbf{M}$ & $\mathbf{N}$ & $\mathbf{O}$ & $\mathbf{P}$ & $\mathbf{Q}$ & $\mathbf{R}$ & $\mathbf{S}$ & $\mathbf{T}$ \\
\hline \hline 1 & 1 & 1 & 1 & 1 & 1 & 1 & 1 & 0 & 1 & 1 & 0 & 1 & 0 & 0 & 1 & 0 & 0 & 0 & 0 & 0 \\
2 & 1 & 1 & 1 & 1 & 1 & 1 & 1 & 0 & 1 & 1 & 0 & 1 & 0 & 0 & 0 & 0 & 0 & 0 & 0 & 0 \\
3 & 1 & 1 & 1 & 1 & 1 & 1 & 1 & 0 & 1 & 1 & 0 & 1 & 0 & 0 & 1 & 0 & 0 & 0 & 1 & 0 \\
4 & 0 & 1 & 1 & 1 & 1 & 1 & 1 & 1 & 1 & 1 & 1 & 1 & 1 & 1 & 1 & 1 & 0 & 0 & 1 & 0 \\
5 & 0 & 0 & 0 & 0 & 0 & 1 & 1 & 1 & 1 & 1 & 1 & 1 & 1 & 1 & 1 & 1 & 1 & 0 & 1 & 0 \\
6 & 0 & 0 & 0 & 0 & 0 & 1 & 1 & 1 & 1 & 1 & 1 & 1 & 1 & 1 & 1 & 1 & 1 & 1 & 1 & 1 \\
7 & 0 & 0 & 0 & 0 & 0 & 1 & 0 & 1 & 1 & 1 & 1 & 1 & 1 & 1 & 1 & 1 & 1 & 0 & 1 & 1 \\
8 & 0 & 0 & 0 & 0 & 0 & 1 & 0 & 1 & 1 & 1 & 1 & 1 & 1 & 1 & 1 & 1 & 1 & 1 & 1 & 1 \\
9 & 0 & 0 & 0 & 0 & 0 & 1 & 0 & 1 & 0 & 1 & 1 & 1 & 1 & 1 & 1 & 1 & 1 & 1 & 1 & 1 \\
10 & 1 & 0 & 1 & 0 & 0 & 0 & 1 & 1 & 0 & 0 & 1 & 1 & 1 & 1 & 1 & 1 & 1 & 1 & 1 & 1 \\
11 & 1 & 1 & 0 & 0 & 0 & 1 & 1 & 1 & 0 & 0 & 0 & 1 & 1 & 1 & 1 & 1 & 1 & 1 & 1 & 1 \\
12 & 1 & 1 & 1 & 0 & 0 & 1 & 1 & 1 & 0 & 0 & 0 & 0 & 0 & 1 & 0 & 1 & 1 & 1 & 1 & 1 \\
\hline
\end{tabular}

Tabela 5.15: Dados discretizados das células HeLa. Cada linha representa um instante de tempo. Os nomes dos genes estão resumidos por uma letra maiúscula, como segue: CCNE1(A), E2F1(B), CDC6 (C), PCNA(D), RFC4(E), DHFR(F), RRM2(G), RAD51(H), CDC2(I), TOP2A(J), CCNF(K), CCNA2(L), STK15(M), BUB1(N), CCNB1(O), PLK(P), PTTG1(Q), RAD21(R), VEGFC(S) e CDKN3(T).

Em um dos experimentos, iniciamos com uma semente $S=\{$ E2F1, CCNA2, CDC2 $\}$ e $d=8$. Os parâmetros utilizados foram $a=2, b=3$ e $\mathcal{M}=1000$. Em um primeiro experimento, fixamos o gene CDC2 como hub, pois ele é conhecido por ter um papel chave no ciclo celular. O histograma das entropias é apresentado na Fig. 5.16. Na Fig. 5.17 temos a rede inferida possuindo a menor entropia (0.01). Como neste caso não temos a rede ground truth, validamos os resultados buscando na literatura pelas interações inferidas, indicadas pelas arestas sólidas na Fig. 5.17. Para isso, utilizamos a ferramenta NCBI Gene ${ }^{3}$. Por exemplo, a interação entre CDC2 e E2F1 é relatada em (Fagan et al., 1994). Além disso, ao invés de calcular a matriz de confusão, calculamos a razão $L / T$, onde $L$ é o número de arestas que encontramos na literatura e $T$ o total de arestas. Devemos ressaltar que consideramos as interações encontradas na literatura de maneira simétrica. Assim, uma referência de interação entre dois genes A e B, implica que

\footnotetext{
${ }^{3}$ http://www.ncbi.nlm.nih.gov/gene
} 
consideramos uma aresta de A para B e uma aresta de B para A, para calcular a razão $L / T$. Para a rede da Fig. 5.17 temos $L / T=0.29$.

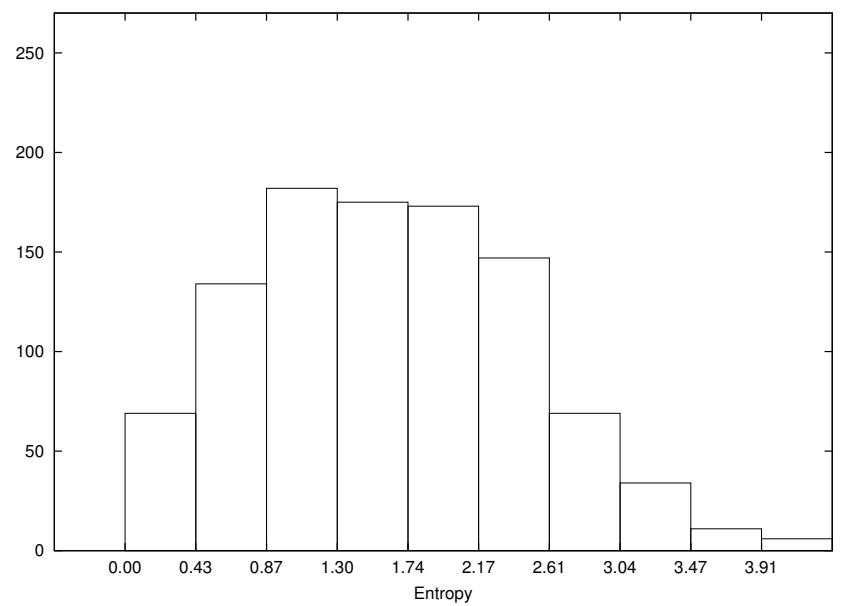

Figura 5.16: Histograma das entropias, considerando o gene CDC2 como hub, para os dados de células HeLa.

O diagrama de transição de estados da rede da Fig. 5.17 é apresentado na Fig. 5.18. A rede possui 3 atratores singletons, e a maior bacia possui 2046 estados, de um total de $2^{11}=2048$. Assim como no modelo da levedura (Li et al., 2004), existe um caminho na maior bacia que converge para o atrator, denotado pelo caminho em negrito na Fig. 5.18.

A maior razão $L / T$ considerando o gene CDC2 como $h u b$ é 0.47 e a rede correspondente é ilustrada na Fig. 5.19. A entropia desta rede é 0.45 e o seu correspondente diagrama de transição de estados é apresentado na Fig. 5.20. A razão $L / T$ média das 100 redes possuindo a menor entropia é 0.34 .

Em um outro experimento, não consideramos um gene $h u b$ na rede. O histograma das entropias é apresentado na Fig. 5.21. Entre as 100 redes possuindo a menor entropia, a rede da Fig. 5.22 é aquela que possui a maior razão $L / T$, cujo valor é 0.48 . O correspondente diagrama de transição de estados é ilustrado na Fig. 5.23. Este diagrama possui 15 atratores e a maior bacia de atração possui 1984 estados (dos 2048 possíveis). É possível ver que a via representada pela série temporal está contida na maior bacia, apesar de que o atrator singleton não é alcançado pela via. A rede possuindo a menor entropia é apresentada na Fig. 5.24.

\section{Comparação com o algoritmo de crescimento de semente anterior}

A comparação de novos algoritmos de inferência propostos com algoritmos já existentes faz-se necessário para a validação de um novo algoritmo, porém comparar estes algoritmos é uma tarefa difícil. A primeira dificuldade está na comparação de algoritmos que utilizam modelos de redes de regulação gênica diferentes. Por exemplo, um algoritmo baseado em um modelo contínuo e outro baseado em um modelo discreto. O primeiro modelo captura informações mais detalhadas sobre o mecanismo de regulação gênica, enquanto que o segundo representa a relação entre genes/proteínas de uma maneira menos detalhada. Mesmo quando o mesmo modelo é utilizado pode ser difícil realizar uma comparação. O algoritmo que desenvolvemos, por exemplo, utiliza 


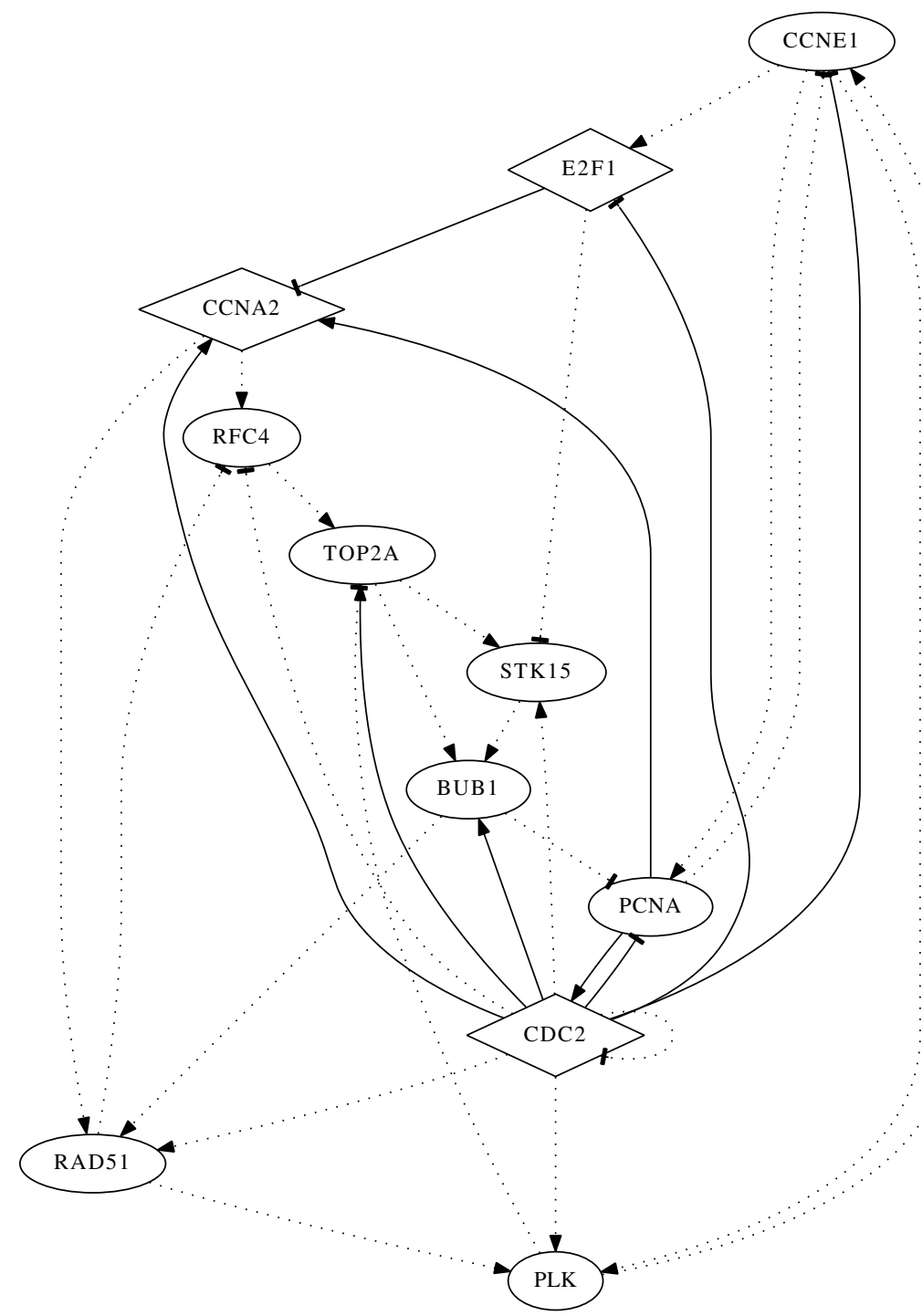

Figura 5.17: Rede possuindo a menor entropia (0.01) considerando o gene CDC2 como hub. Arestas sólidas representam interações encontradas na literatura.

redes Booleanas e o processo de inferência leva em consideração a dinâmica (bacias de atração) das redes analisadas. Existem outros algoritmos que também utilizam redes Booleanas, mas que não se preocupam com a dinâmica das redes inferidas. Sendo assim, comparar dois algoritmos de maneira justa é difícil, pois um pode ser melhor no que diz respeito à dinâmica das redes inferidas, enquanto que o outro pode ser melhor com relacão às relações entre genes recuperadas (geralmente medidas em termos de taxa de verdadeiros positivos e falsos negativos).

Para efeitos de comparação, utilizamos os dados artificiais do ciclo celular da levedura e comparamos os resultados obtidos com relação ao algoritmo de crescimento de semente proposto anteriormente por (Hashimoto et al., 2004). Ambos os algoritmos foram testados utilizando 20 sementes iniciais distintas. Para cada semente, calculamos a similaridade entre a rede original (rede $A$ ) e a rede inferida (rede $B$ ). A similaridade é definida por

$$
\text { Similaridade }(A, B)=\sqrt{\text { Sensibilidade } \times \text { Especificidade }},
$$




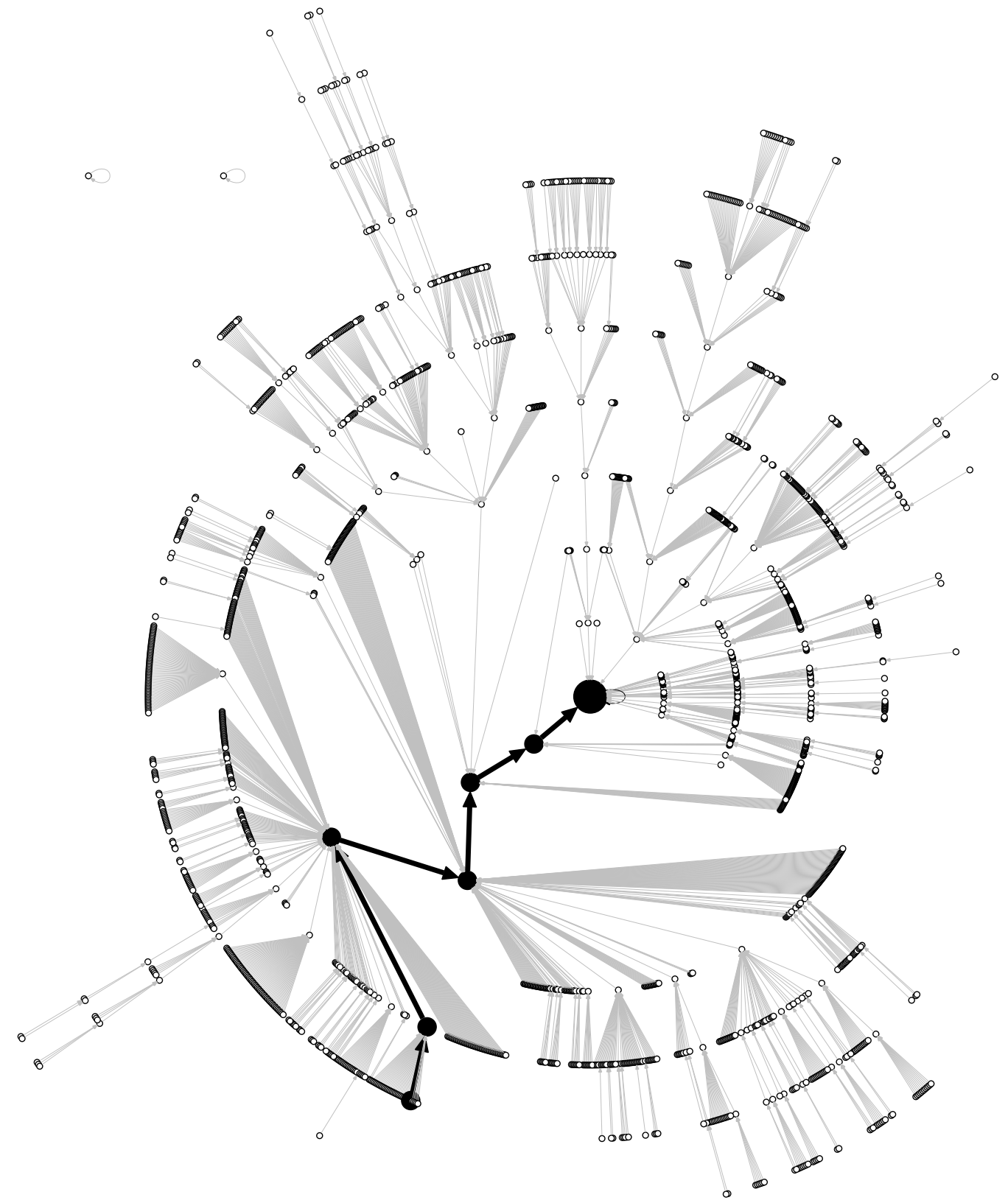

Figura 5.18: Diagrama de transição de estados da rede da Fig. 5.17. O caminho em negrito denota a via dada pela série temporal das células HeLa.

onde Sensibilidade $=T P /(T P+F P)$ e Especificidade $=T N /(T N+F P)(T P, F P$ e $T N$ são definidos na Tabela 5.11).

Na Tabela 5.16 apresentamos os valores das similaridades obtidas pelo algoritmo anterior e pelo algoritmo proposto. Para o algoritmo proposto, consideramos a maior similaridade encontrada entre as 100 redes possuindo as menores entropias. Podemos perceber que o algoritmo proposto apresenta valores maiores de similaridade.

\section{Discussões}

No caso do dados artificiais, a rede com a menor entropia não corresponde necessariamente ao melhor ponto (FPR, TPR) no espaço ROC. Da mesma maneira, no caso das células HeLa, 


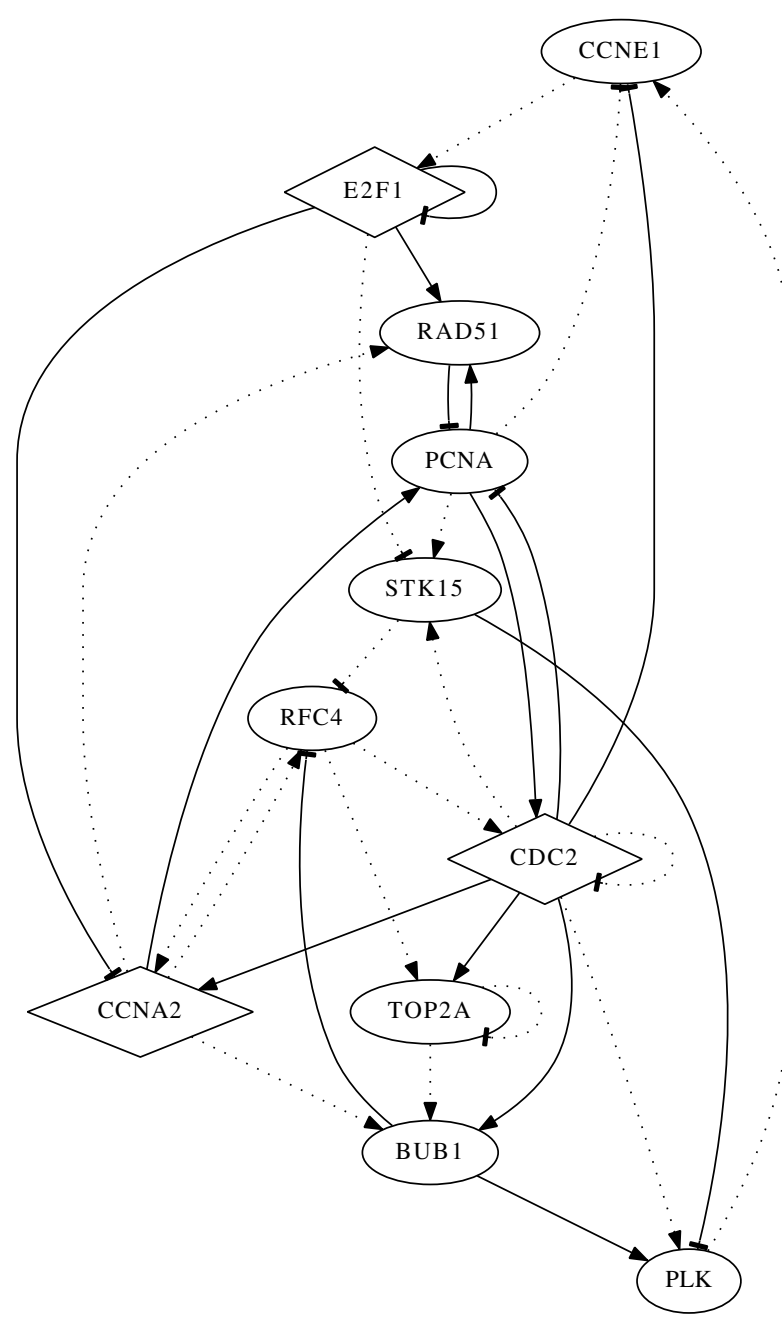

Figura 5.19: Rede possuindo a maior razão $L / T$ (0.47).

a rede com a menor entropia não corresponde à rede possuindo a maior razão $L / T$. Como esperado, não podemos garantir que a rede com a menor entropia possua o maior número de arestas que correspondam as arestas da rede ground truth ou referenciadas na literatura. Podemos apenas garantir que esta rede é estável e que esta estabilidade é biologicamente desejável. No caso da levedura, podemos ver na rede ground truth (Fig. 3.2) que apenas o gene Cln3 possui conectividade $k_{i}=1$, e que para outros cinco genes (Sic1, Cdh1, Clb1, Cdc20 e Swi5) temos $k_{i}>3$. Como utilizamos os parâmetros $a=2$ e $b=3$, sabemos que para estes genes não podemos recuperar todas as arestas de entrada. Apesar disso, o valor médio da taxa de verdadeiro positivo (0.73 e 0.71 , com e sem um gene $h u b$, respectivamente) é perfeitamente aceitável. Como na maioria dos algoritmos de inferência de redes, o método apresentado provê uma maneira de gerar e estudar hipóteses de regulações gênicas. Por exemplo, os gráficos de barras (e.g., Fig. 5.4 e 5.5) podem ser utilizados para analisar as conexões entre os genes e realizar uma verificação em wetlab. As arestas determinadas e parcialmente determinadas, por exemplo, podem ser interessantes neste aspecto.

Os histogramas das entropias mostraram que apesar de existirem diversas redes consistentes com os dados, a maioria delas não é estável, se definirmos "estável" como sendo uma rede 


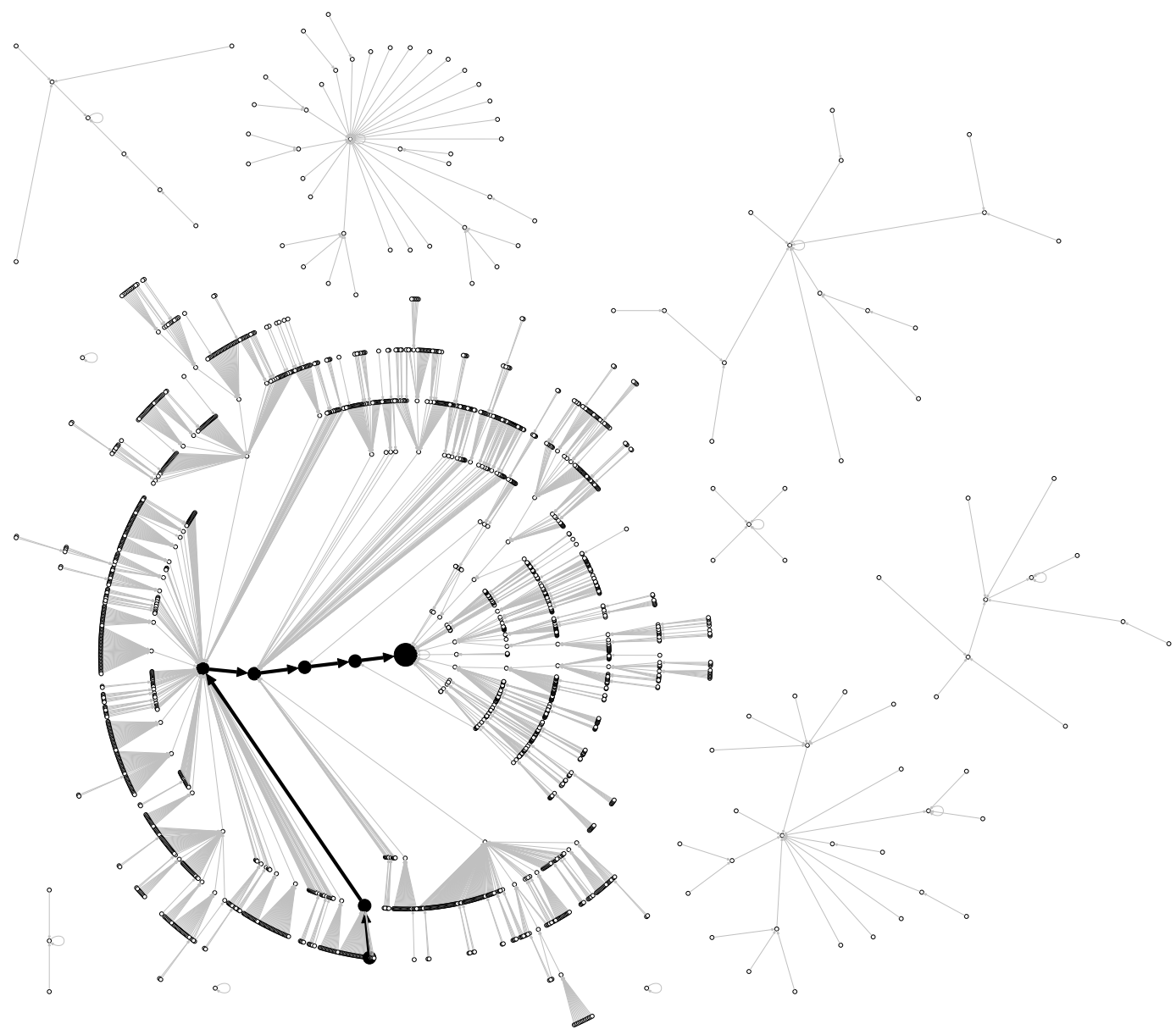

Figura 5.20: Diagrama de transição de estados da rede da Fig. 5.19.

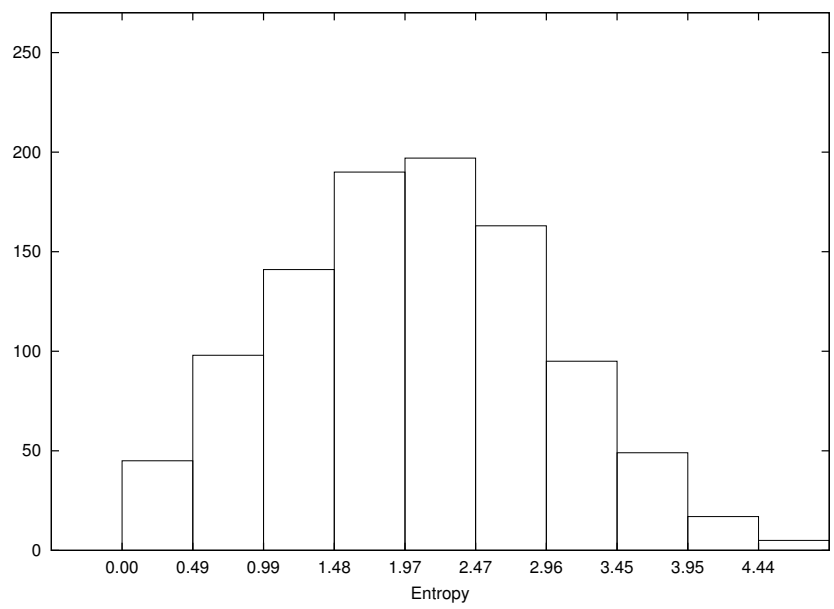

Figura 5.21: Histograma das entropias, sem considerar um gene hub, para os dados de células HeLa.

possuindo poucos atratores e uma bacia grande (entre outras bacias pequenas). Observando os diagramas de transição de estados, a via representada pela série temporal geralmente aparece na maior bacia, como esperado. Em alguns casos, o atrator faz parte desta via. Em outros casos, por exemplo, na Fig. 5.23, a via flui em direção ao atrator mas não o alcança, talvez devido ao pequeno número de amostras. Vale notar que o número de estados cresce exponencialmente com 


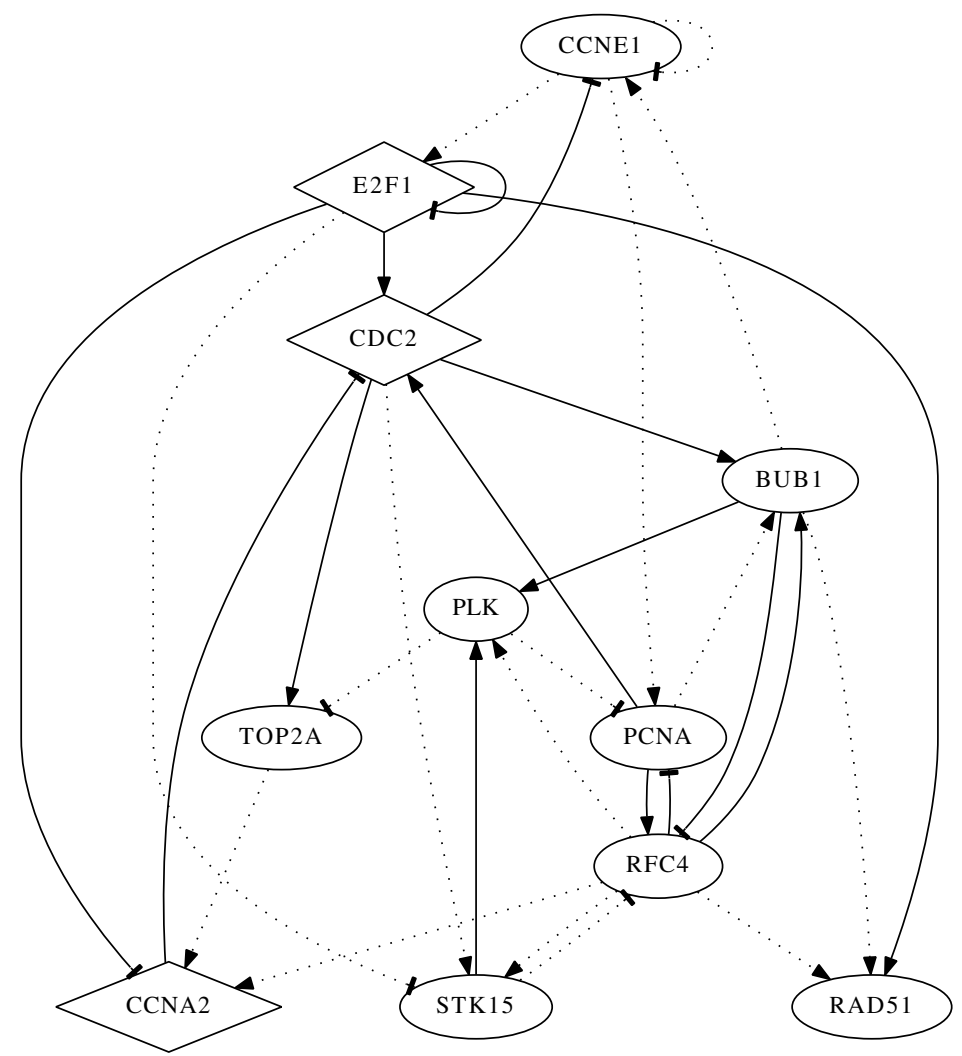

Figura 5.22: Rede inferida possuindo a maior razão $L / T$ (0.48), sem considerar um gene hub.

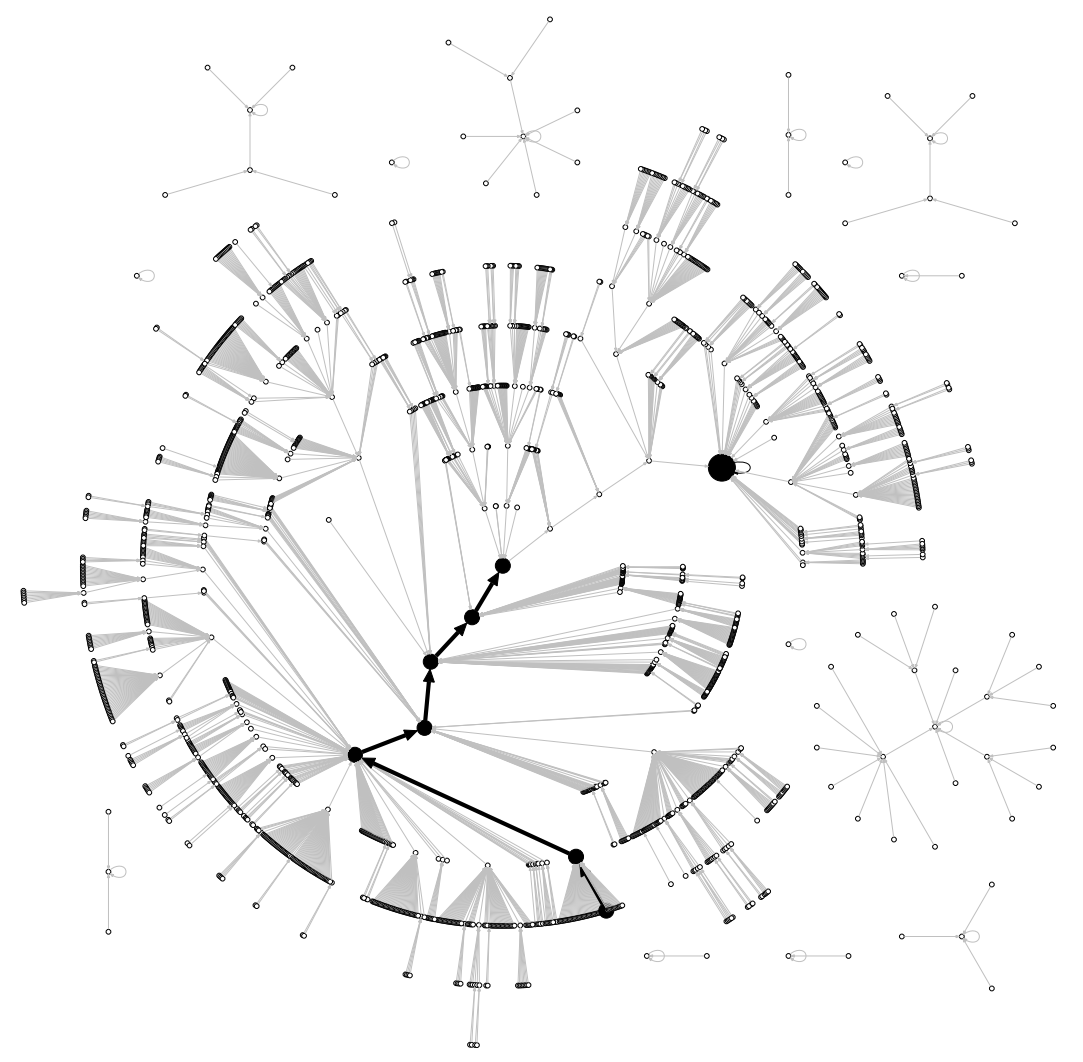

Figura 5.23: Diagrama de transição de estados da rede da Fig. 5.22. 


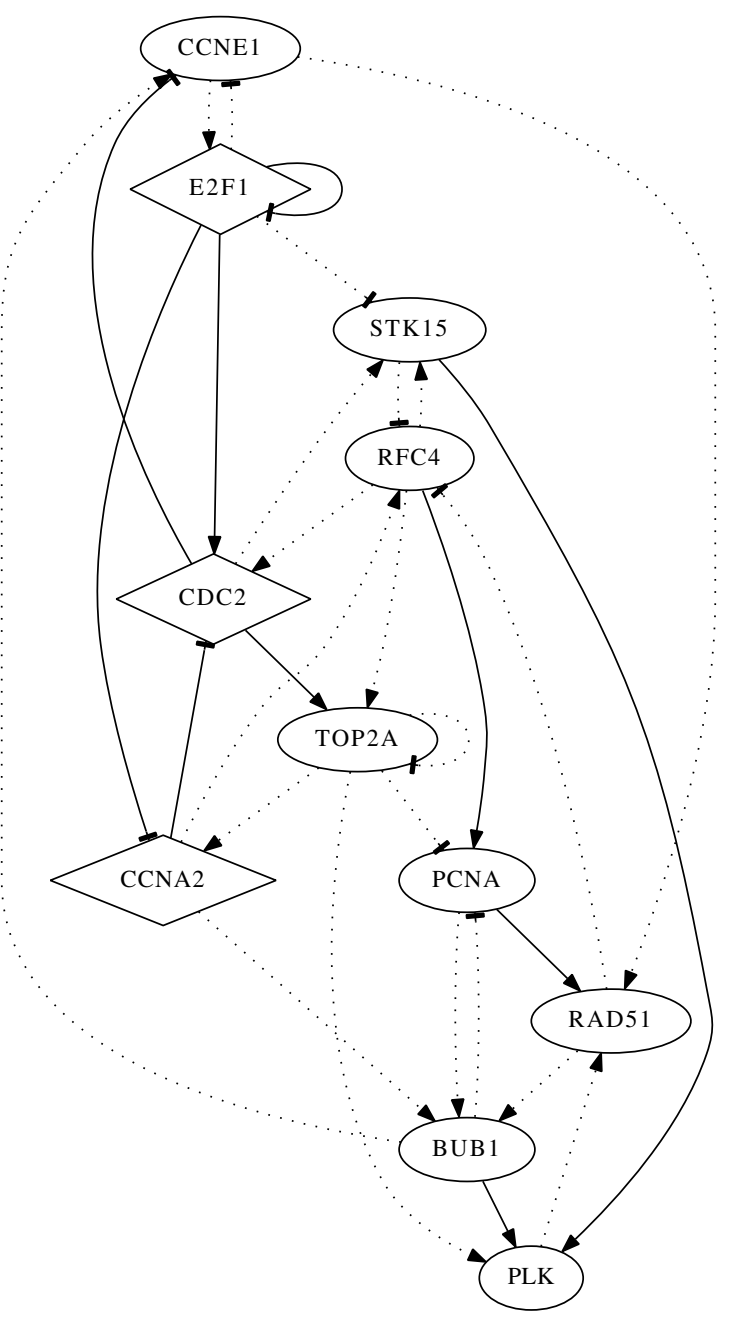

Figura 5.24: Rede inferida possuindo a menor entropia (0.006), sem considerar um gene hub.

o número de genes, mas uma grande quantidade de estados não são biologicamente significantes, como afirmado em (Huang, 1999; Kauffman, 1993). Os estados que se encontram no caminho em direção ao atrator são aqueles que certamente possuem algum significado biológico.

Como mencionamos, uma desvantagem do método é que o tempo de execução é exponencial no número de genes. Assim, sua aplicação é adequada quando o número de genes é pequeno. Este é o preço pago para gerar diversas redes, ao invés de apenas uma, e analisar a dinâmica destas redes. Em uma situação onde o número de genes é grande, uma pré-seleção de um subconjunto menor de genes por um especialista pode ser feita. Outra abordagem seria aplicar um algoritmo de agrupamento, e selecionar um representante de cada grupo.

As diversas redes que compõem a saída do algoritmo podem ser analisadas por um biólogo especialista e auxiliá-lo em experimentos em wetlab. Uma análise através de gráficos de barras, como da Fig. 5.3, também pode ser realizada com as redes inferidas. Assim, este método mostra-se útil para a inferência de redes de regulação gênica. 


\begin{tabular}{|c|c|c|}
\hline Semente \# & Anterior & Proposto \\
\hline \hline 1 & 0.10 & 0.71 \\
\hline 2 & 0.25 & 0.61 \\
\hline 3 & 0.10 & 0.63 \\
\hline 4 & 0.43 & 0.48 \\
\hline 5 & 0.28 & 0.57 \\
\hline 6 & 0.28 & 0.46 \\
\hline 7 & 0.10 & 0.54 \\
\hline 8 & 0.38 & 0.41 \\
\hline 9 & 0.28 & 0.57 \\
\hline 10 & 0.10 & 0.61 \\
\hline 11 & 0.28 & 0.57 \\
\hline 12 & 0.28 & 0.52 \\
\hline 13 & 0.25 & 0.57 \\
\hline 14 & 0.53 & 0.62 \\
\hline 15 & 0.27 & 0.72 \\
\hline 16 & 0.27 & 0.44 \\
\hline 17 & 0.38 & 0.50 \\
\hline 18 & 0.39 & 0.73 \\
\hline 19 & 0.39 & 0.62 \\
\hline 20 & 0.28 & 0.48 \\
\hline
\end{tabular}

Tabela 5.16: Similaridades obtidas pelo algoritmo de crescimento de semente anterior e o algoritmo proposto, para cada uma das 20 sementes testadas. 


\section{Capítulo 6}

\section{Conclusões}

\subsection{Considerações finais}

Organismos biológicos são complexos e em alguns aspectos ainda não são completamente compreendidos pelo homem. Sendo assim, é necessário que o conhecimento das mais diversas áreas (Biologia, Química, Matemática, Física, Ciência da Computação) seja aplicado em conjunto para que possamos cada vez mais compreender tais organismos. Em particular, a elucidação de mecanismos regulatórios pode nos auxiliar no compreendimento de fenômenos biológicos relacionados às doenças, como por exemplo, o câncer.

Neste trabalho, abordamos dois tópicos principais: a modelagem do ciclo celular da levedura (Sacchacomyces cerevisiae) e a inferência de redes de regulação gênica usando o paradigma de crescimento de semente. Com relação à modelagem, iniciamos este trabalho estudando modelos já existentes para o ciclo celular. Em particular, estudamos um modelo discreto e determinístico proposto por (Li et al., 2004), e uma versão estocástica deste modelo, proposta por (Zhang et al., 2006). Após este estudo, propomos uma extensão destes modelos, baseado em redes Booleanas probabilísticas sensíveis ao contexto, ou modelo cPBN. Este modelo, por sua vez, serviu de base para um segundo modelo proposto, baseado em cadeias de Markov não homogêneas (NHMC). Nos modelos que estudamos, após a divisão celular, a célula permanece em um estado chamado $\mathrm{G}_{1}$ estacionário por tempo indeterminado. É conhecido que o início do ciclo celular da levedura tem início através do crescimento da célula e da ciclina Cln3 em combinação com a quinase ciclina-dependente Cdc28 (ou Cdk1) (Cross, 1988). Uma vez que a célula inicia o processo de divisão, ela sai do estado $G_{1}$ estacionário. Nos modelos que propomos, este comportamento é modelado explicitamente, enquanto mantém a robustez apresentada pelos modelos anteriores.

A inferência de redes a partir de dados de expressão gênica é um problema mal posto e complexo. Primeiramente, estudamos o coeficiente de determinação $(\mathrm{CoD})$ para identificar interações entre genes. Em um caso real, estes CoDs são estimados através dos dados de expressão gênica. Fizemos um estudo teórico, calculando os CoDs (estacionários) a partir de uma distribuição de probabilidade estacionária previamente conhecida. Esta distribuição foi obtida através do modelo de (Zhang et al., 2006). Dessa maneira, foi possível analisar os resultados comparando as interações identificadas com a rede conhecida (ground truth). Nossas análises mostraram uma certa dificuldade em recuperar as interações conhecidas através dos CoDs estacionários. Como 
tentamos inferir a rede do ciclo celular, que é um fenômeno bem definido e dividido em fases, acreditamos que o fator tempo é essencial neste caso.

Um estudo teórico foi realizado, onde propomos os CoDs temporais, calculados através de uma matriz de transição de estados de uma cadeia de Markov ergódica e sua respectiva distribuição estacionária. Também utilizamos o modelo de (Zhang et al., 2006) neste estudo. Analisando os resultados, notamos uma significante melhoria, quando comparados com os resultados dos CoDs estacionários. A desvantagem do CoD temporal está no fato de que precisamos obter uma matriz de transição de estados. Uma abordagem para recuperar uma matriz de transição a partir de dados pode ser utilizada neste caso, como por exemplo, proposta em (Martins-Jr et al., 2009).

No caso em que poucas amostras de dados temporais estão disponíveis, propomos uma abordagem baseada em problemas de satisfação de restrições (CSP) para analisar as interações gênicas. Utilizamos o modelo de redes Booleanas com limiar (tBN) e os dados temporais para gerar restrições para o CSP. Um CSP solver foi usado para encontrar as soluções, que neste caso são linhas (consistentes com os dados) da matriz de regulação de uma tBN. Aplicamos esta metodologia em dados artificiais e biológicos de células HeLa. Os resultados mostraram que os dados restringem algumas conexões entre genes. No caso de células HeLa, o pouco número de amostras e uma quantidade maior de genes faz com que exista uma grande quantidade de linhas (e portanto, matrizes) consistentes com os dados. Um número maior de amostras poderia ajudar a restringir o espaço contendo estas linhas consistentes. De fato, nos dois casos, dados artificiais e biológicos, o conhecimento a priori pode ajudar a restringir algumas interações gênicas. Este fato reforça a necessidade da participação/integração de biólogos especialistas durante o processo de inferência. A metodologia proposta pode ser utilizada para guiar experimentos em wetlab.

Esta metodologia baseada em CSP foi utilizada no algoritmo de inferência de redes proposto. Este algoritmo tenta inferir pequenas redes contendo um subconjunto de genes, usando o paradigma de crescimento de semente. Neste contexto, uma semente é um pequeno subconjunto de genes de interesse, e "crescer" a semente significa agregar outros genes a este subconjunto, segundo algum critério. O algoritmo é baseado em dois passos: passo de crescimento e passo de amostragem. O primeiro passo pode ser visto como um problema de seleção de características. Assim, usamos como base um algoritmo chamado IFFS (Nakariyakul e Casasent, 2009) para selecionar os genes a serem agregados à semente. Utilizamos características do modelo tBN para projetar a função critério. No segundo passo, realizamos uma amostragem no espaço de redes consistentes com os dados, e filtramos algumas redes segundo um critério baseado na estabilidade destas redes.

Aplicamos o algoritmo em dados artificiais e biológicos de células HeLa. No caso de dados artificiais, utilizamos o modelo de (Li et al., 2004) para gerar os dados. Após a inferência, uma análise ROC foi realizada, mostrando resultados satisfatórios. Observando o diagrama de transição de estados das redes inferidas, alguns podem ser vistos como uma versão reduzida do diagrama da rede original. Para os dados biológicos, buscamos na literatura por interações conhecidas para validar as redes inferidas, encontrando resultados satisfatórios.

Uma característica interessante do nosso algoritmo é que a sua saída não é composta de uma única rede, e sim um conjunto de redes selecionadas segundo algum critério. Como mencionamos acima, o critério que adotamos leva em consideração a estabilidade de uma rede. Este conjunto 
de redes pode ser analisado por um biólogo especialista com o objetivo de guiar experimentos em wetlab. A participação de um biólogo também pode ser importante neste processo de inferência. Por exemplo, para pré-selecionar um gene hub. Em nossos experimentos com células HeLa, utilizamos o gene CDC2 como $h u b$ pois sabemos que este gene/proteína interage com uma variedade de genes/proteínas.

Com relação à complexidade de tempo do algoritmo, por ser exponencial no número de genes, sabemos que a sua aplicação está limitada a um conjunto pequeno de genes. No caso em que citamos, em que se deseja inferir uma rede pequena de genes, o tempo de execução é perfeitamente aceitável. Utilizando a biblioteca Gecode e uma implementação multithread, um dos experimentos utilizando células HeLa levou cerca de 7 minutos de execução (utilizando um processador Intel Core 2 Duo $2.00 \mathrm{GHz}$ ).

\subsection{Sugestões para pesquisas futuras}

Em nossos estudos com os CoDs temporários, os resultados apresentados são bastante teóricos e que ainda precisam ser aplicados em dados de expressão gênica. Os tCoDs dependem da matriz de transição que modela o processo biológico sendo estudado. Obter uma matriz a partir de dados também é, por sua vez, um problema inverso mal posto. Assim, a aplicação prática dos tCoDs pode ser investigada futuramente.

Muitos algoritmos de inferência têm sido propostos mas ainda necessitam ser aperfeiçoados (Marbach et al., 2010). No trabalho apresentado, utilizamos basicamente dados de expressão gênica, ou seja, transcriptoma. Outros tipos de dados estão se tornando cada vez mais disponíveis, como por exemplo, dados de interação proteína-proteína (proteomics) e de processos químicos envolvendo metabólitos (metabolomics). A ideia é que cada vez mais possamos integrar estes dados para melhorar os procedimentos de inferência de interações gênicas. Além disso, é necessário aplicar a nossa metodologia utilizando outros dados e em colaboração com um biólogo especialista que possa nos ajudar a aperfeiçoar o algoritmo.

No nosso algoritmo de inferência, dada uma tBN, precisamos construir seu diagrama de transição de estados. Este é um passo que pode consumir muito tempo, dependendo do número de genes. Sendo assim, a implementação do método tem um grande impacto no tempo de execução de um experimento. Nós implementamos este passo utilizando programação multithreading. Certamente, esta implementação pode ser aperfeiçoada utilizando técnicas de programação GPGPU (general-purpose computing on graphics processing unit) (Owens et al., 2007).

Além da modelagem e da inferência, outra possibilidade é estudar o controle de redes de regulação gênica, com o objetivo de determinar estratégias de intervenção terapêutica para alterar a dinâmica de uma rede, evitando estados indesejáveis, como citado em (Dougherty et al., 2010; Ghaffari et al., 2011). Este tipo de estudo pode ajudar a encontrar genes ou interações gênicas importantes em um processo biológico investigado.

Outro tópico que pode ser estudado é a redução de redes Booleanas. Quando trabalhamos com estas redes, o número de estados cresce exponencialmente com o número de genes. Sendo assim, estudos com o objetivo de reduzir tais redes também têm sido realizados, como em (Ghaffari et al., 2010). 


\section{Apêndice A}

\section{Resultados - células HeLa 1}

Neste apêndice, apresentamos os gráficos de barras para todos os genes do estudo envolvendo células HeLa (Seção 5.2.3).

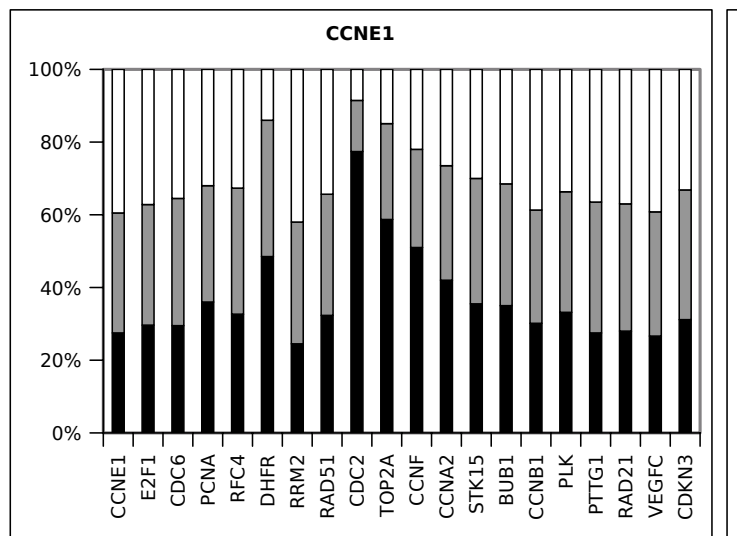

(a)

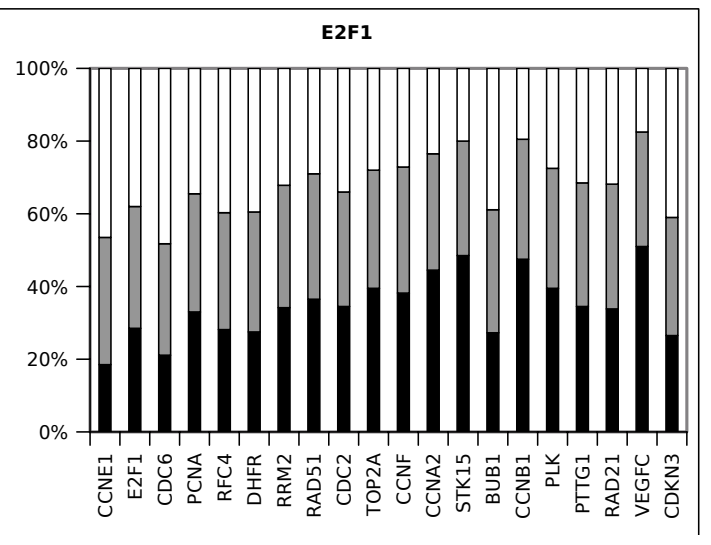

(b)

Figura A.1: Gráfico de barras para os genes CCNE1 e E2F1. 


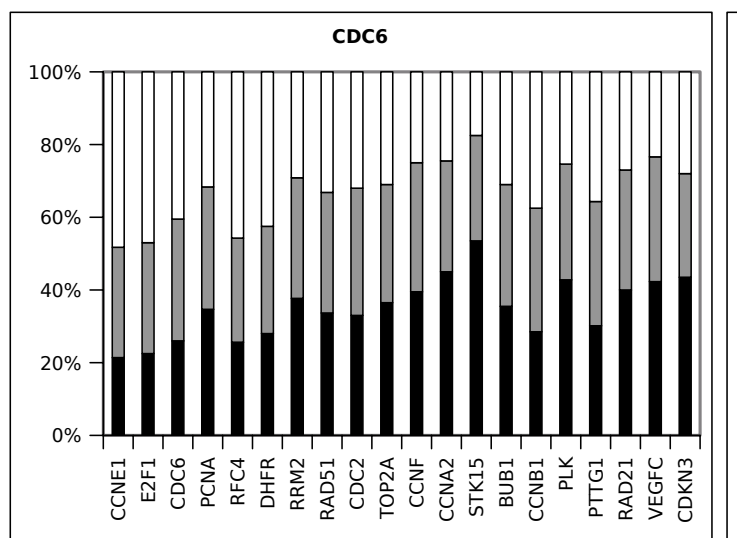

(a)

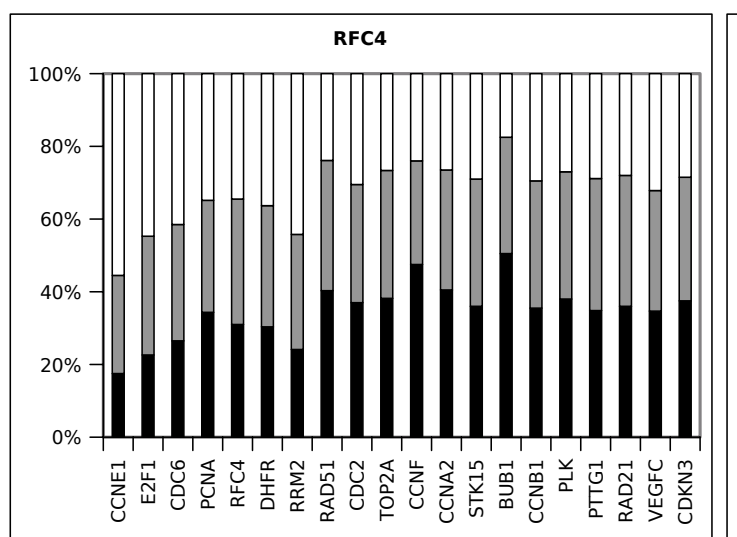

(c)

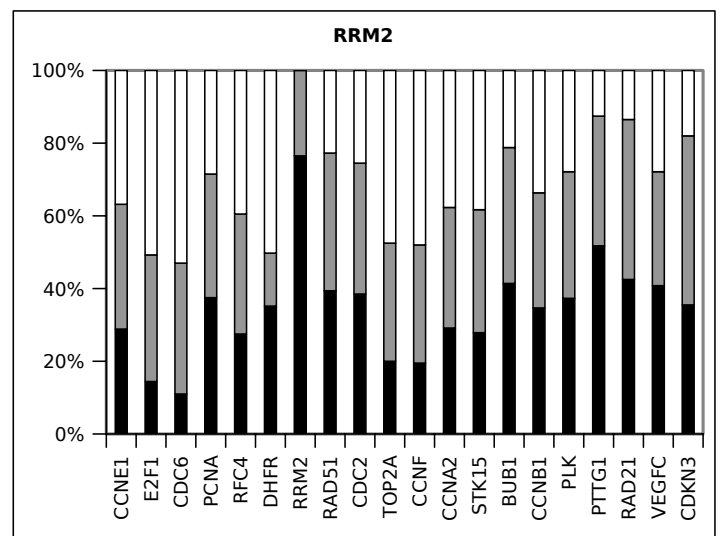

(e)

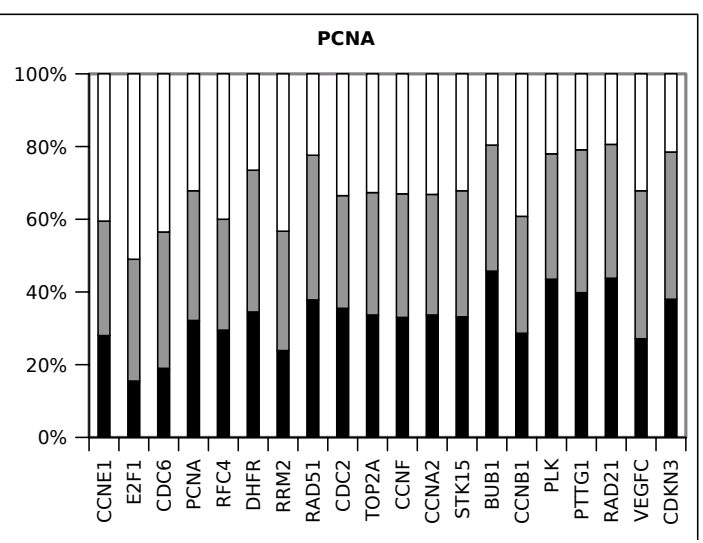

(b)

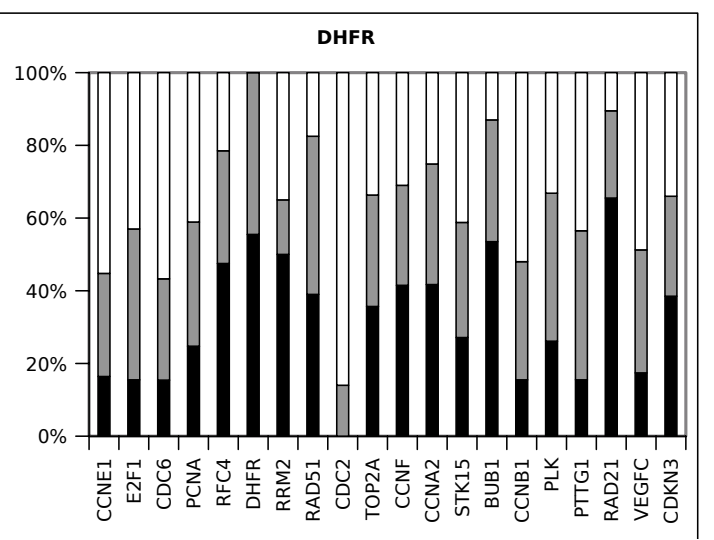

(d)

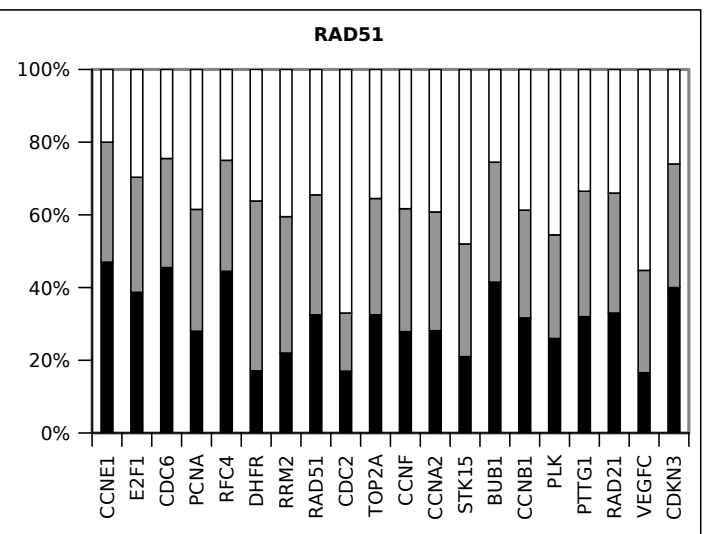

(f)

Figura A.2: Gráfico de barras para os genes CDC6, PCNA, RFC4, DHFR, RRM2 e RAD51. 


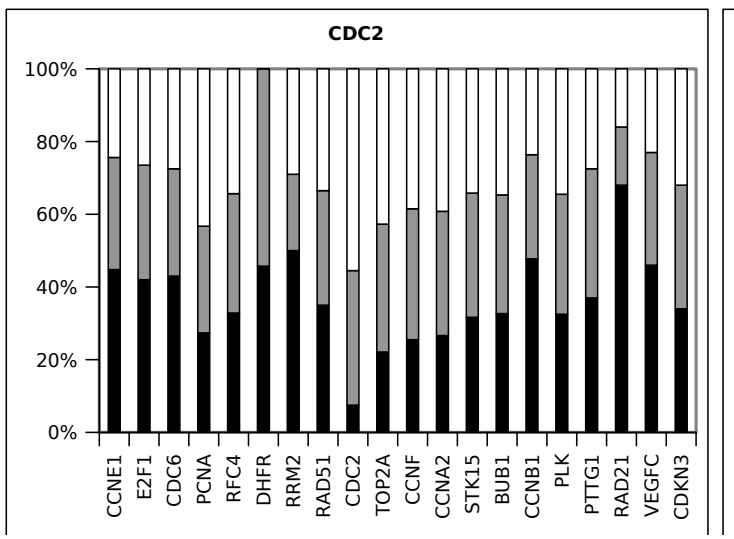

(a)

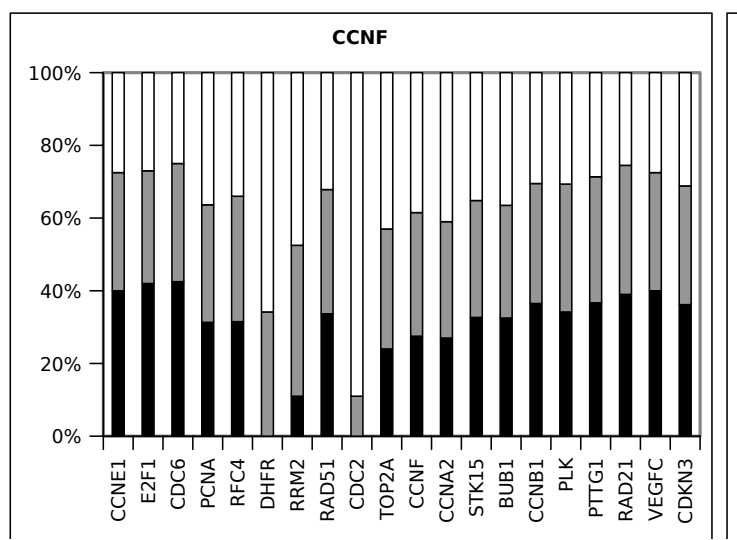

(c)

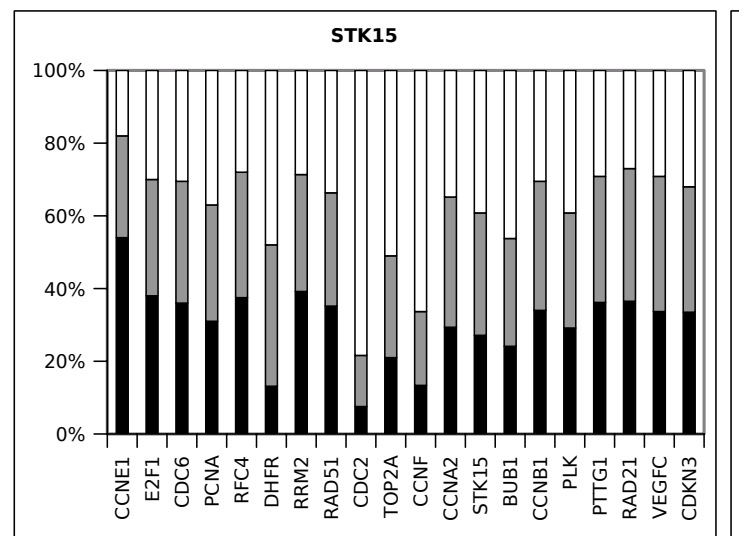

(e)

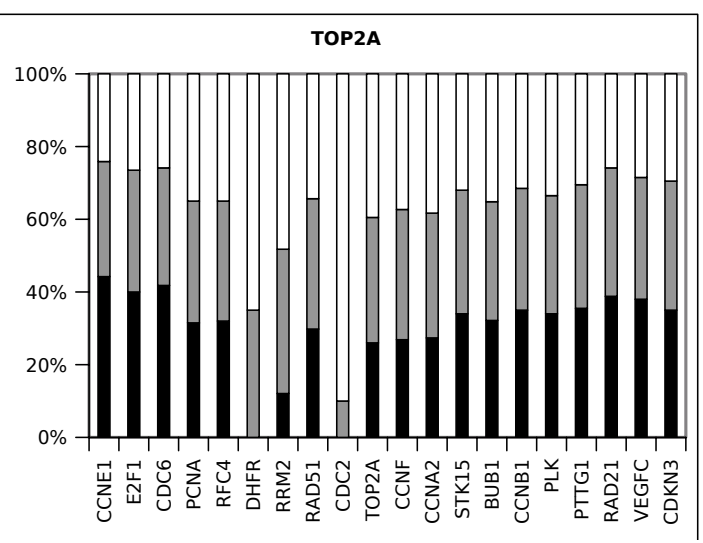

(b)

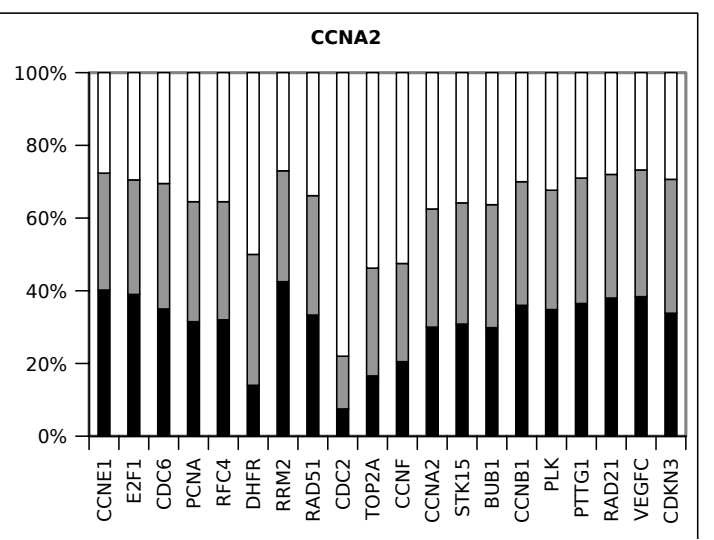

(d)

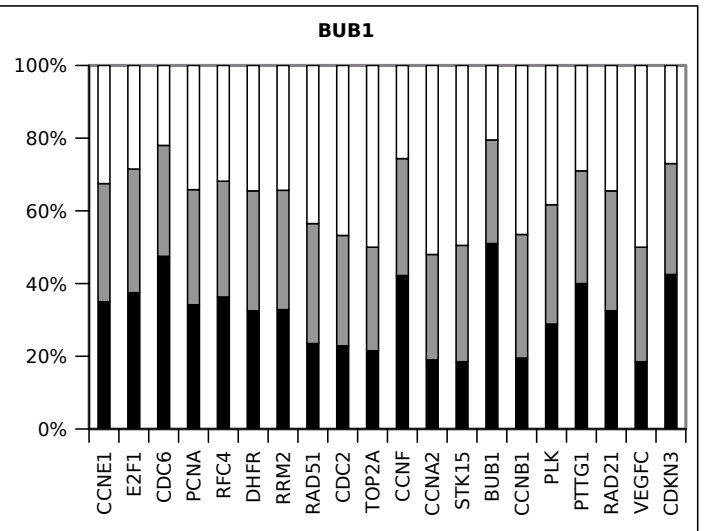

(f)

Figura A.3: Gráfico de barras para os genes CDC2, TOP2A, CCNF, CCNA2, STK15 e BUB1. 


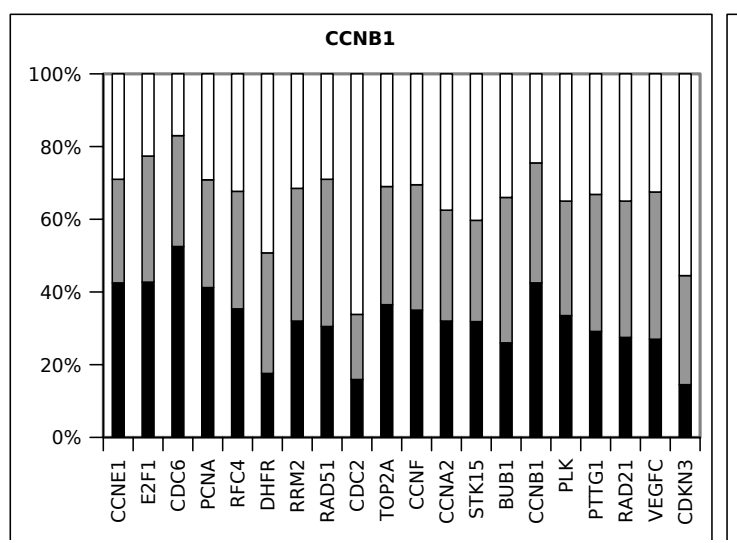

(a)

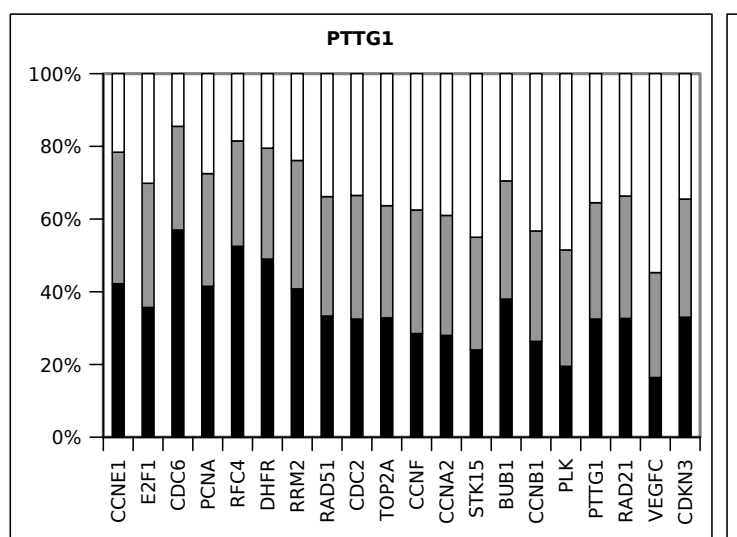

(c)

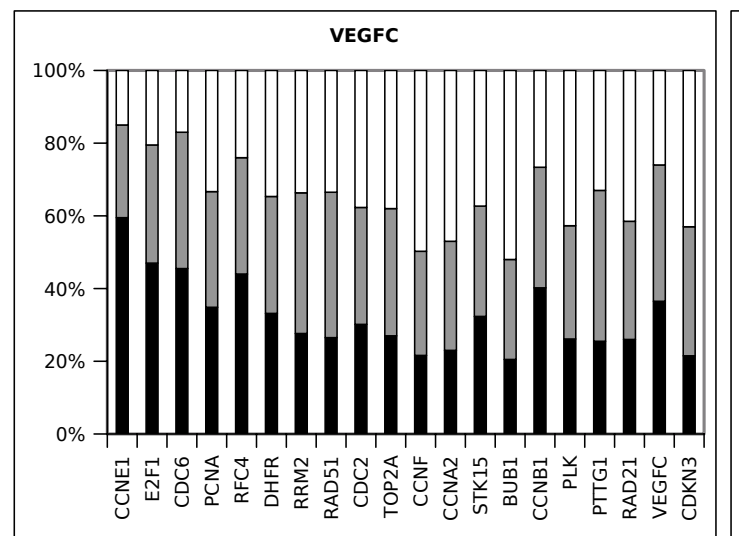

(e)

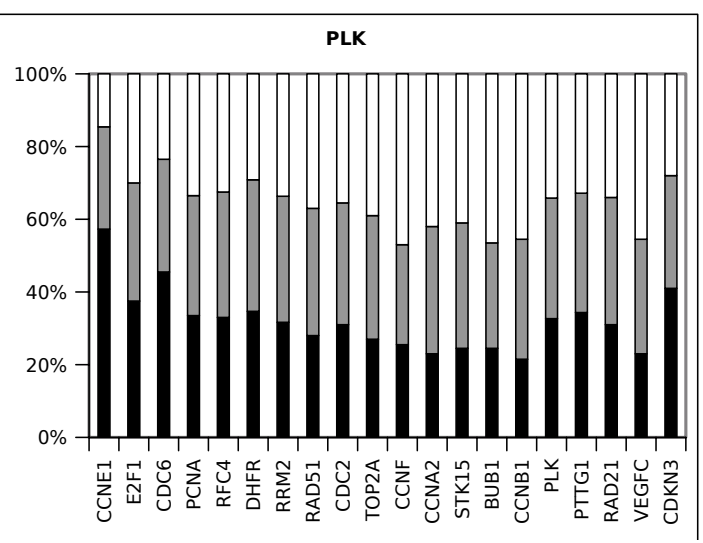

(b)

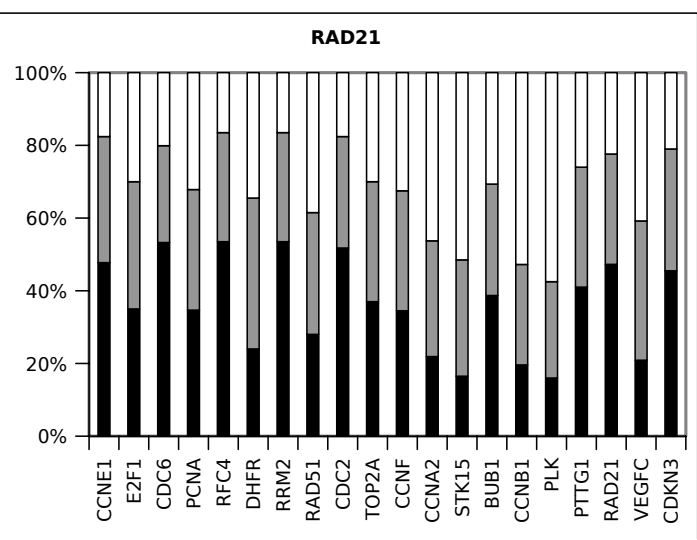

(d)

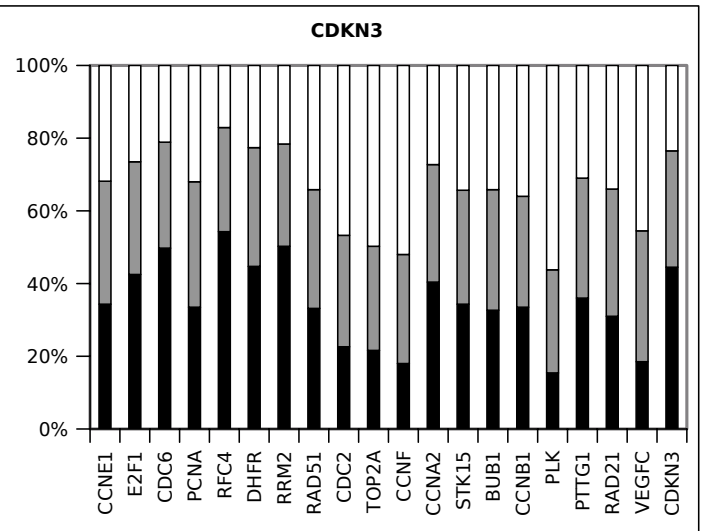

(f)

Figura A.4: Gráfico de barras para os genes CCNB1, PLK, PTTG1, RAD21, VEGFC e CDKN3. 


\section{Apêndice B}

\section{Resultados - células HeLa 2}

Neste apêndice, apresentamos os gráficos de barras para todos os genes do estudo envolvendo células HeLa, considerando o conhecimento biológico (Seção 5.2.3).

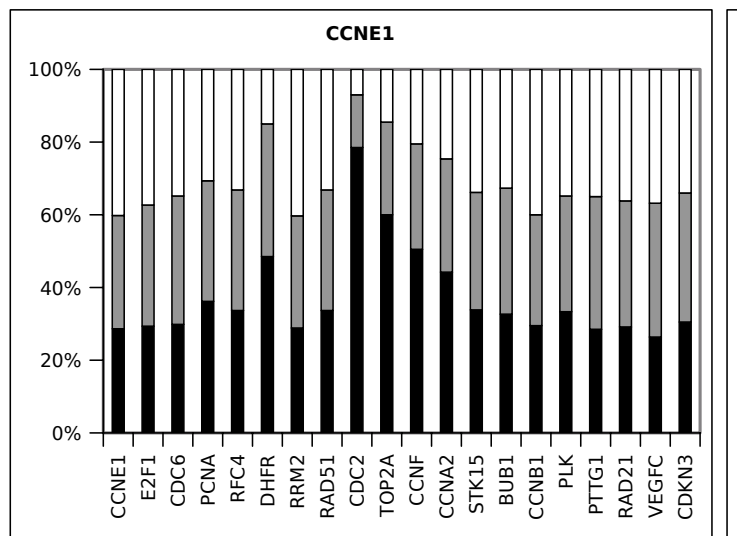

(a)

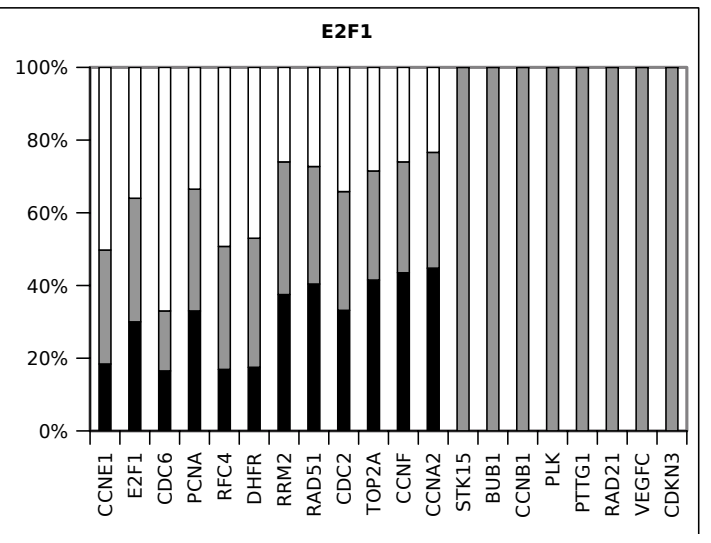

(b)

Figura B.1: Gráfico de barras para os genes CCNE1 e E2F1. 


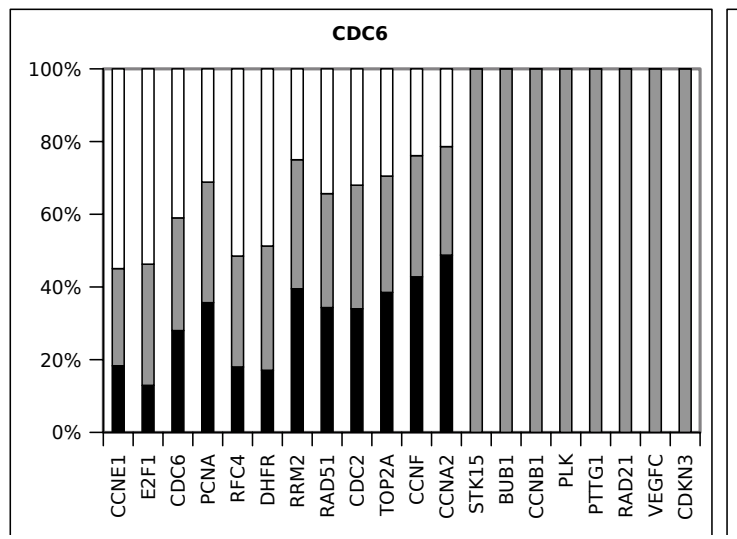

(a)

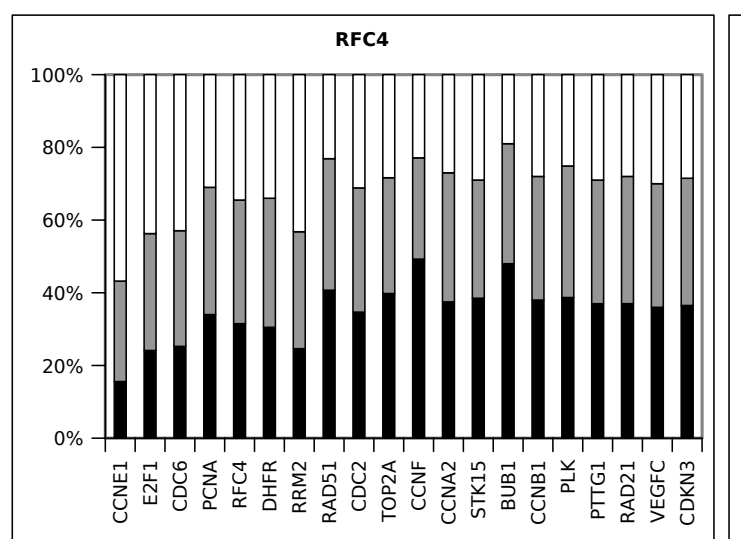

(c)

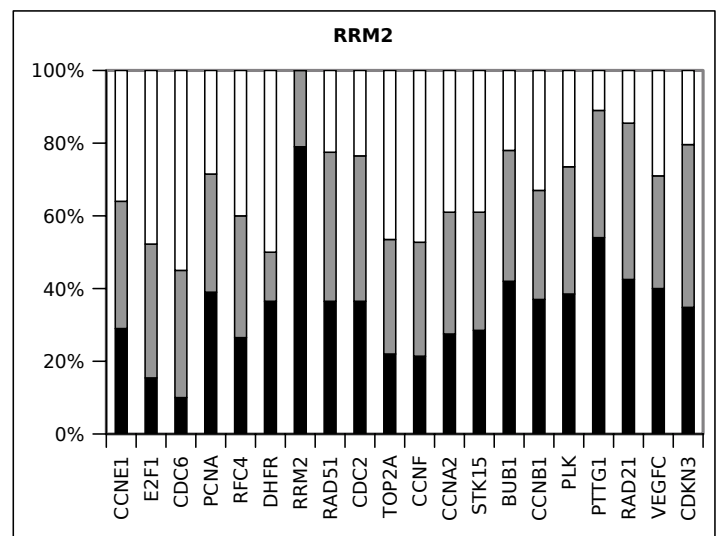

(e)

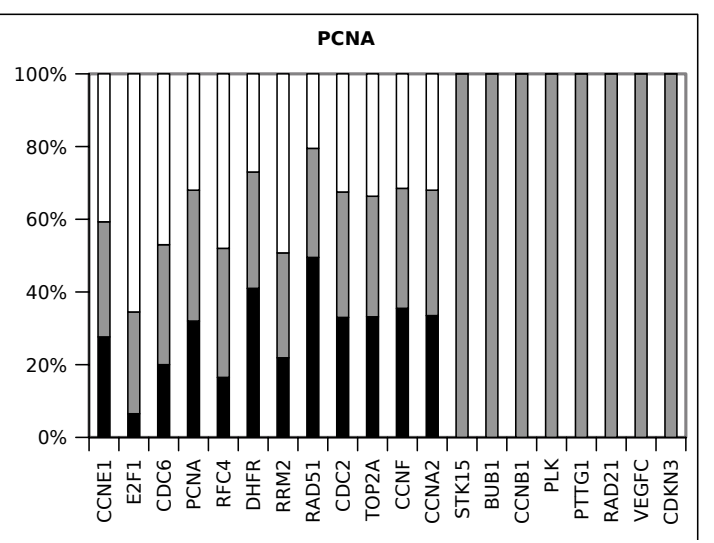

(b)

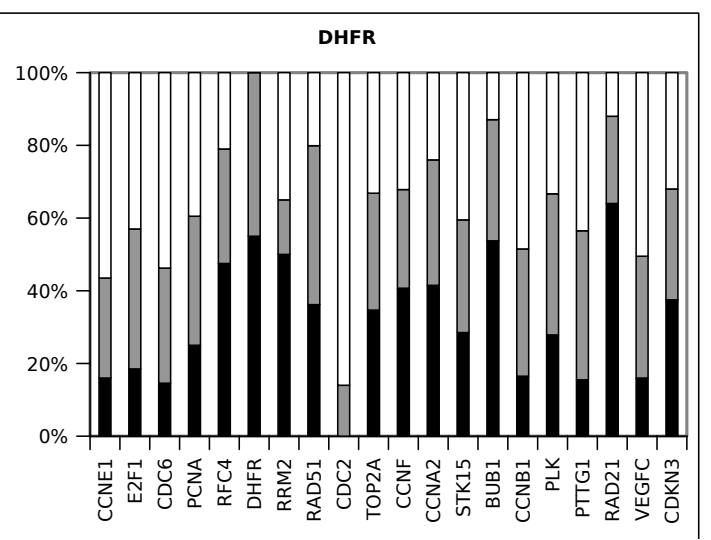

(d)

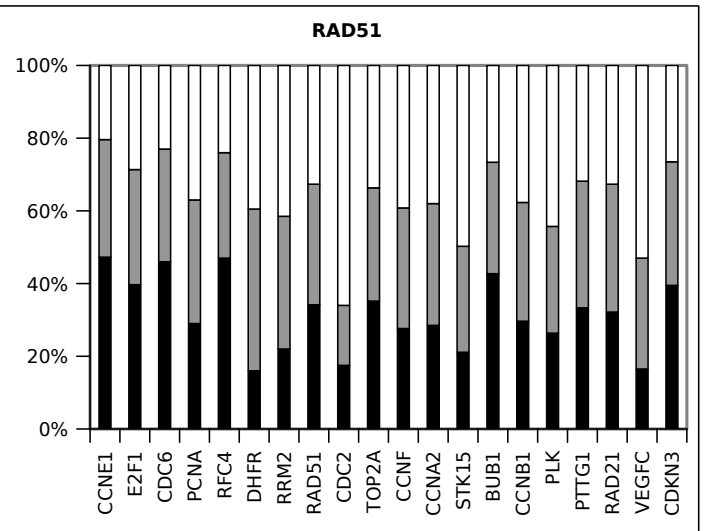

(f)

Figura B.2: Gráfico de barras para os genes CDC6, PCNA, RFC4, DHFR, RRM2 e RAD51. 


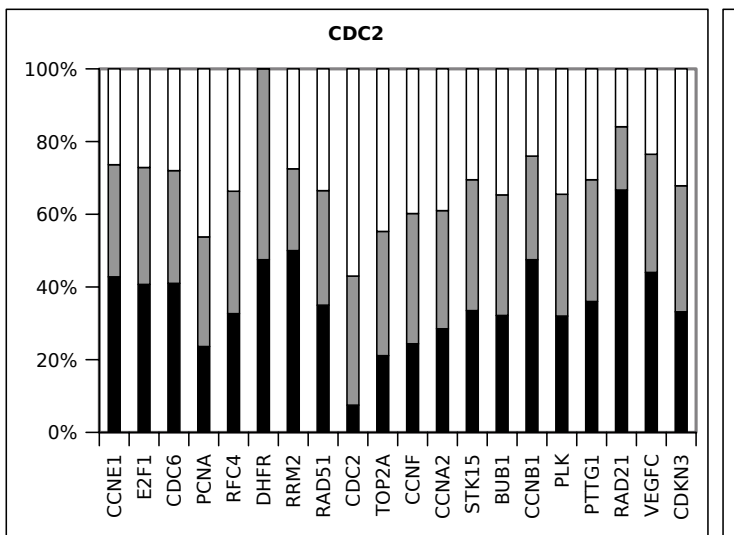

(a)

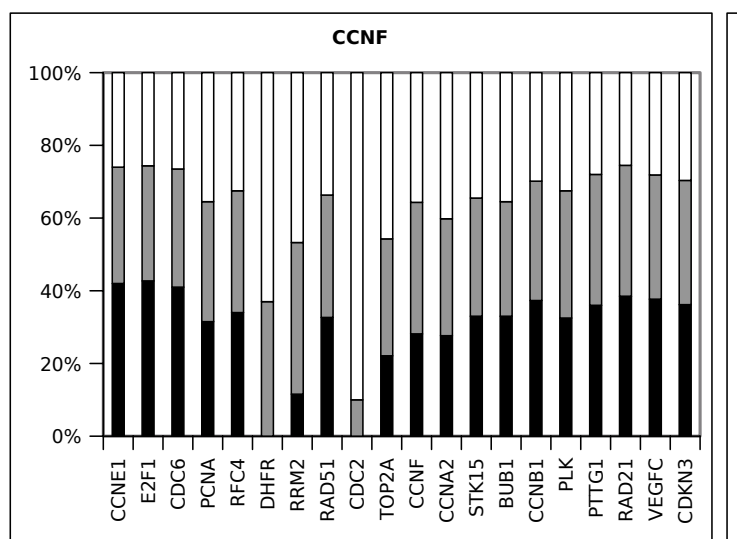

(c)

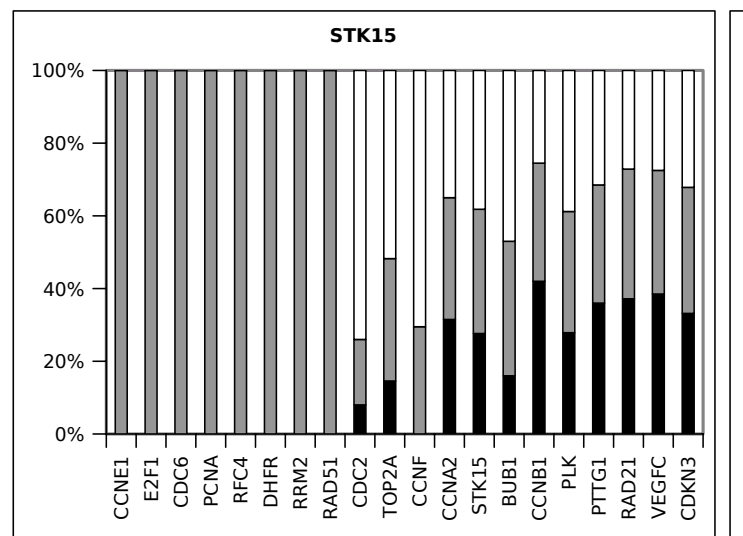

(e)

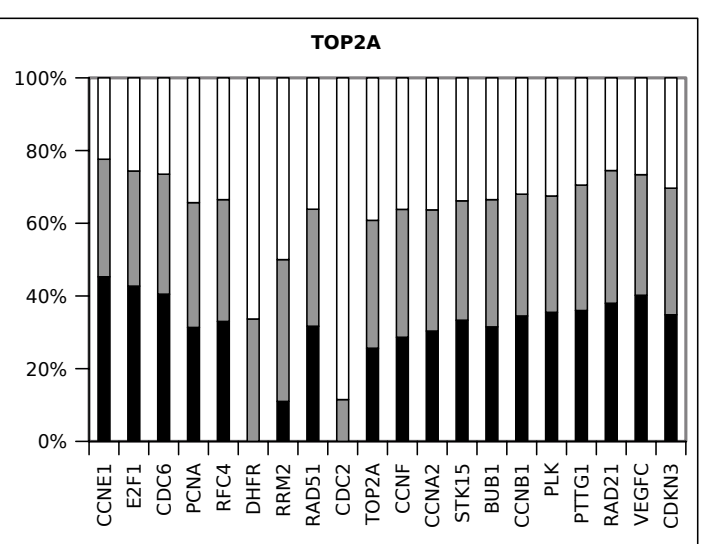

(b)

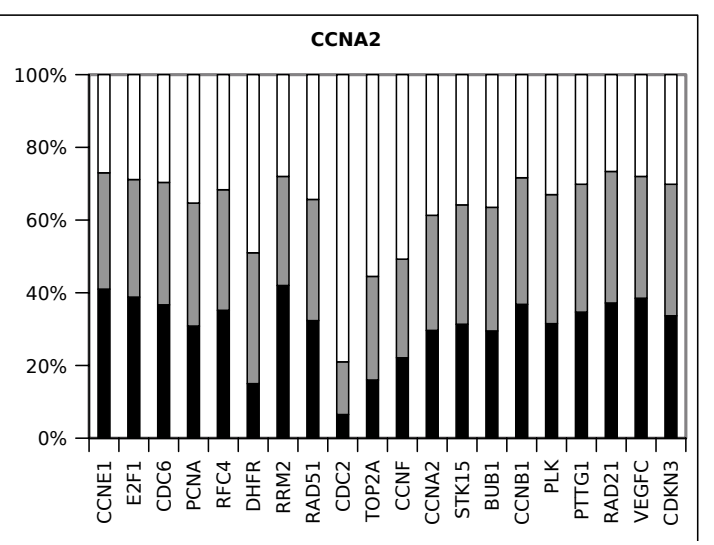

(d)

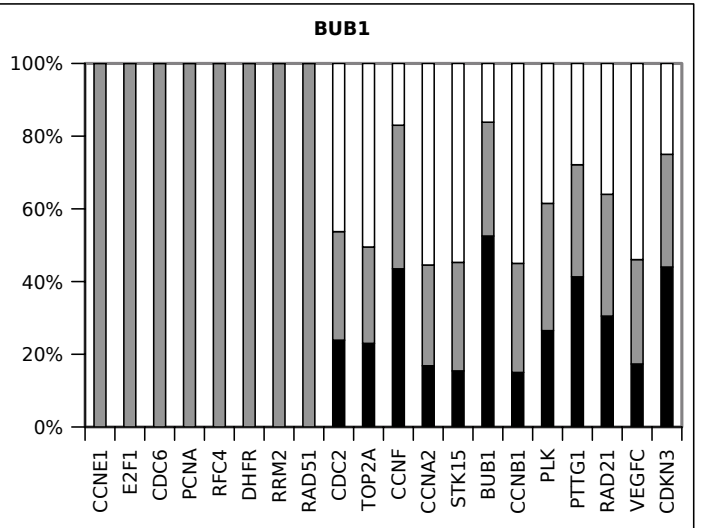

(f)

Figura B.3: Gráfico de barras para os genes CDC2, TOP2A, CCNF, CCNA2, STK15 e BUB1. 


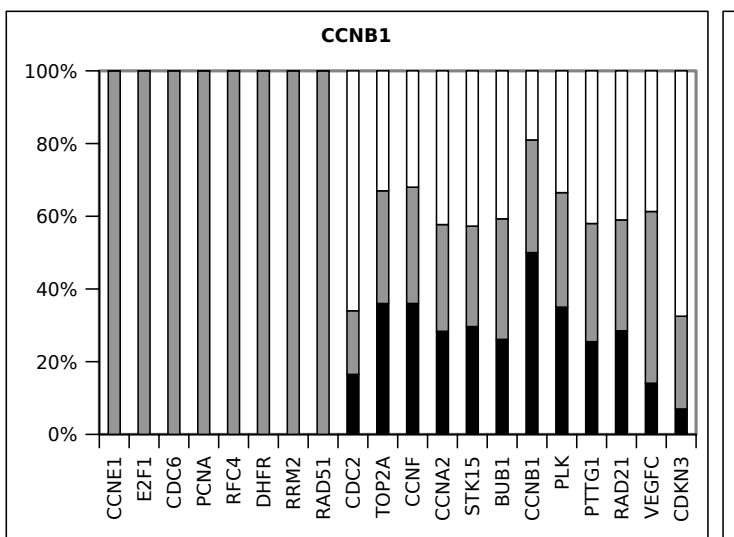

(a)

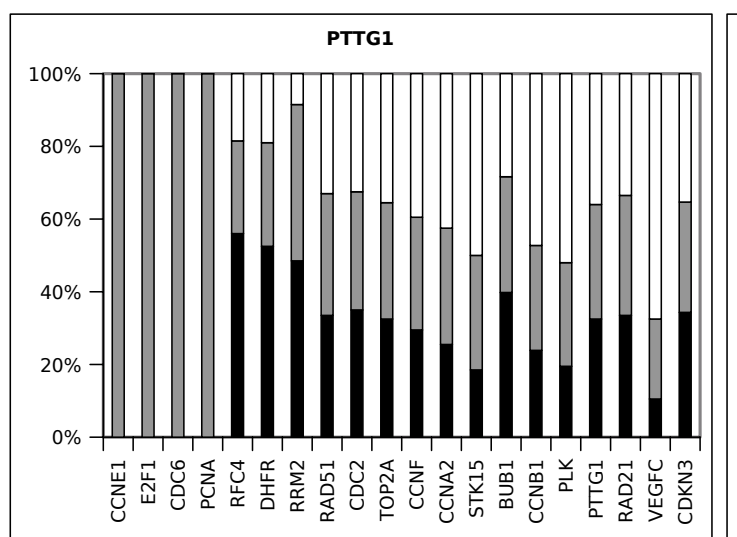

(c)

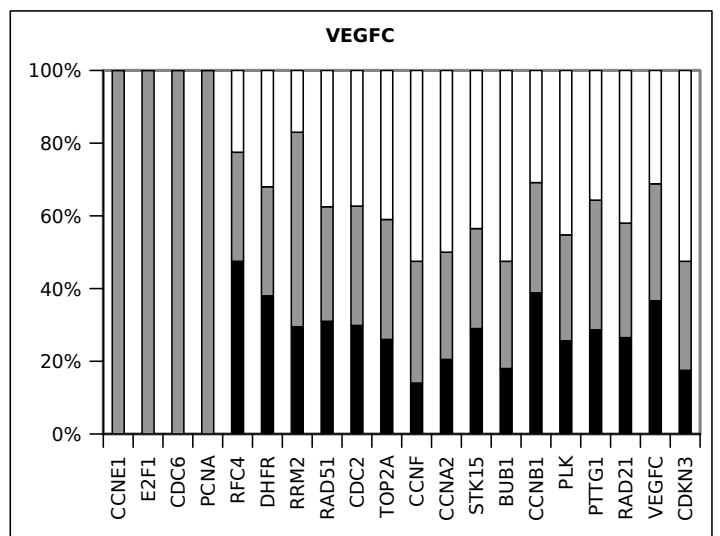

(e)

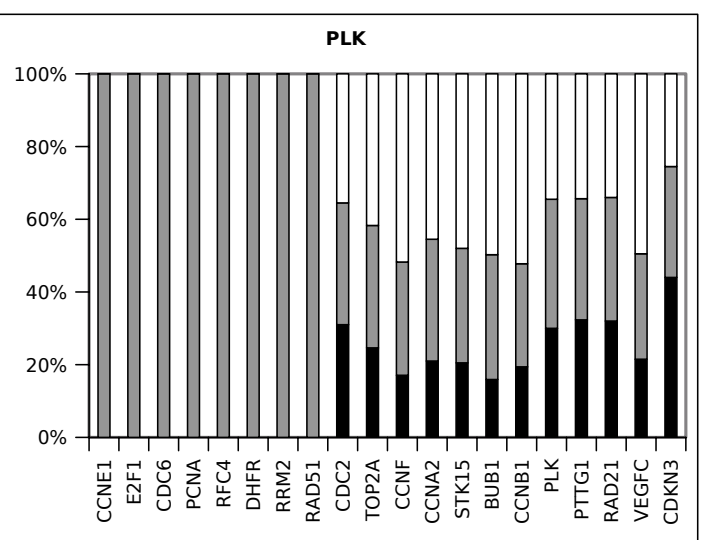

(b)

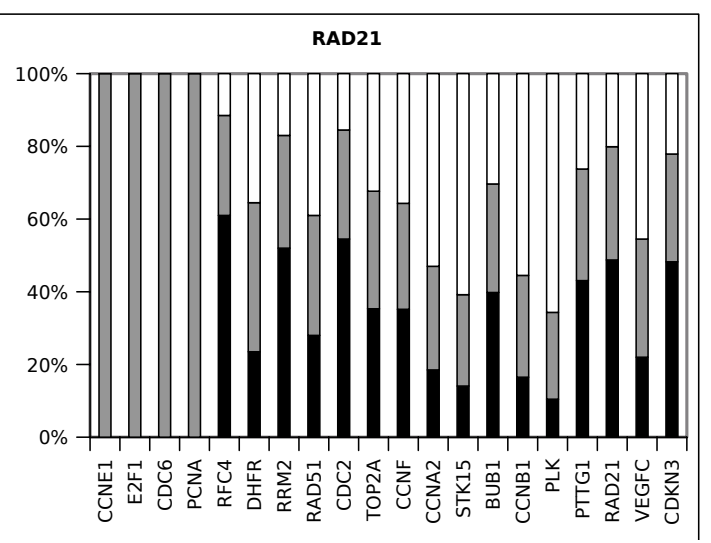

(d)

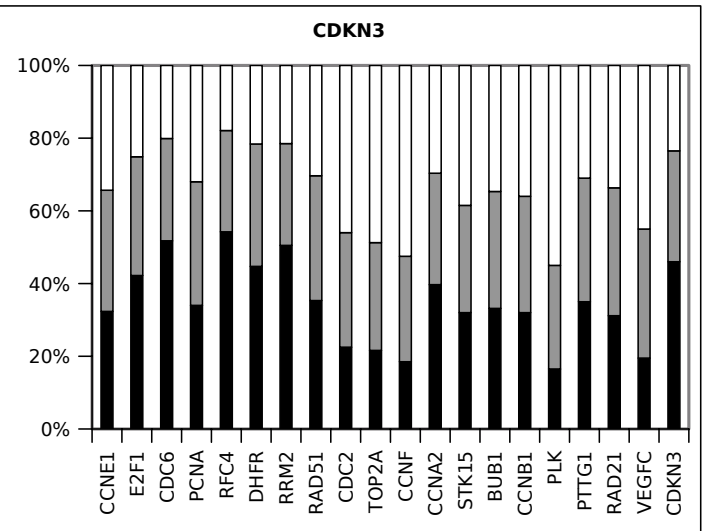

(f)

Figura B.4: Gráfico de barras para os genes CCNB1, PLK, PTTG1, RAD21, VEGFC e CDKN3. 


\section{Apêndice C}

\section{Trabalhos produzidos}

- "Modelling yeast cell-cycle with context probabilistic Boolean network" Carlos H. A. Higa e Ronaldo F. Hashimoto. X-Meeting 2007 - 3rd International Conference of the Brazilian Association for Bioinformatics and Computational Biology, São Paulo-SP Pôster.

- "Considerations on Using CoD for Inference of Gene Regulation Networks" Carlos H. A. Higa, Ronaldo F. Hashimoto, Roberto Hirata-Jr. e Nina S. T. Hirata. XMeeting 2008 - 4th International Conference of the Brazilian Association for Bioinformatics and Computational Biology, Salvador-BA, 2008 - Pôster premiado.

- "Inference of Gene Regulatory Network using Temporal Coefficient of Determination Obtained from Ergodic Markov Chains" Carlos H. A. Higa, Ronaldo F. Hashimoto, Roberto Hirata-Jr., Nina S. T. Hirata e Carlos S. Santos. GENSIPS'09 - IEEE International Workshop on Genomic Signal Processing and Statistics, Minneapolis-MN, 2009.

- "Budding yeast cell cycle modeled by context-sensitive probabilistic Boolean network" Carlos H. A. Higa, Henrique Stagni e Ronaldo F. Hashimoto. GENSIPS'09 IEEE International Workshop on Genomic Signal Processing and Statistics, Minneapolis$M N, 2009$.

- "Analysis of gene interactions using restricted Boolean networks and time-series data" Carlos H. A. Higa, Vitor H. P. Louzada e Ronaldo F. Hashimoto. Proceedings of the 6th Symposium on Bioinformatics Research and Applications - ISBRA 2010, Storrs-CT, 2010.

- "Constraint-based analysis of gene interactions using restricted Boolean networks and time-series data" Carlos H. A. Higa, Vitor H. P. Louzada, Tales P. Andrade e Ronaldo F. Hashimoto. BMC Proceedings 5(Suppl 2):S5, 2011.

- "Growing seed genes from time series data and thresholded Boolean networks with perturbation" Carlos H. A. Higa, Tales P. Andrade e Ronaldo F. Hashimoto. (submetido). 
- "A non homogeneous Markov chain model for the budding yeast cell cycle process" Carlos H. A. Higa, Henrique Stagni e Ronaldo F. Hashimoto. (em preparação). 


\section{Referências Bibliográficas}

Akutsu et al.(1999) T. Akutsu, S. Miyano e S. Kuhara. Identification of genetic networks from a small number of gene expression patterns under the Boolean network model. Pacific Symposium on Biocomputing, páginas 17-28. Citado na pág. 29

Alberts et al.(2007) B. Alberts, A. Johnson, J. Lewis, M. Raff, K. Roberts e P. Walter. Molecular Biology of the Cell. Garland Science, 5 edição. ISBN 0815341059. Citado na pág. 9, 43, 86

Barabási e Albert(1999) A L Barabási e R Albert. Emergence of Scaling in Random Networks. Science, 286:509-512. Citado na pág. 83

Barrera et al.(2004) J. Barrera, R. M. Cesar-Jr e D. C. Martins-Jr. A new annotation tool for malaria based on inference of probabilistic genetic networks. Em Proceedings of the 5th International Conference for the Critical Assessment of Microarray Data Analysis (CAMDA' 94), páginas 36-40. Citado na pág. 16, 17

Barrera et al.(2007) J. Barrera, R. M. Cesar-Jr, D. C. Martins-Jr, R. Z. N. Vêncio, E. F. Merino, M. M. Yamamoto, F. G. Leonardi, C. A. B. Pereira e H. A. Portillo. Constructing probabilistic genetic networks of Plasmodium falciparum from dynamical expression signals of the intraerythrocytic development cycle. Em Methods of Microarray Data Analysis $V$, chapter 2. Springer. Citado na pág. 2, 17, 29

Bilban et al.(2002) M. Bilban, L. K. Buehler, S. Head, G. Desoye e V. Quaranta. Normilizing DNA microarray data. Current Issues in Molecular Biology, 4:57-64. Citado na pág. 11

Braunewell e Bornholdt(2007) S. Braunewell e S. Bornholdt. Superstability of the yeast cell-cycle dynamics: Ensuring causality in the presence of biochemical stochasticity. Journal of Theoretical Biology, 245(4):638-643. Citado na pág. 47

Brun et al.(2005) M. Brun, R. E. Dougherty e I. Shmulevich. Steady-state probabilities for attractors in probabilistic Boolean networks. Signal Processing, 85:1993-2013. Citado na pág. 23, 25

Buck e Lieb(2004) M. J. Buck e J. D. Lieb. ChIP-chip: considerations for the design, analysis, and application of genome-wide chromatin immunoprecipitation experiments. Genomics, 83 (3):349-360. Citado na pág. 2

Butte e Kohane(2000) A. Butte e I. Kohane. Mutual information relevance networks: functional genomic clustering using pairwise entropy measurements. Em Proceeding of the Pacific Symposium on Biocomputing, volume 90, páginas 418-429. Citado na pág. 14, 26

Cai et al.(1997) J. Cai, E. Gibbs, F. Uhlmann, B. Phillips, N. Yao, M. O’Donnell e Hurwitz J. A complex consisting of human replication factor $\mathrm{C}$ p40, p37, and p36 subunits is a DNAdependent ATPase and an intermediate in the assembly of the holoenzyme. Journal of Biological Chemistry, 272(30):18974-18981. Citado na pág. 81 
Catlett(1991) J. Catlett. On changing continuous attributes into ordered discrete attributes. Em Proceedings of the European working session on learning on Machine Learning, páginas 164-178. Springer-Verlag New York. Citado na pág. 12

Chan et al.(1999) A. K. Chan, S. Persad, D. W. Litchfield e J. A. Wright. Ribonucleotide reductase R2 protein is phosphorylated at serine-20 by P34cdc2 kinase. Biochimica et Biophysica Acta (BBA) - Molecular Cell Research, 1448(3):363-371. Citado na pág. 80

Chang et al.(2008) C. Chang, Z. Ding, Y. S. Hung e P. C. W. C. Fung. Fast network component analysis (fastnca) for gene regulatory network reconstruction from microarray data. Bioinformatics, 24(11):1349-1358. Citado na pág. 28

Chen et al.(2004) K. C. Chen, L. Calzone, A. Csikasz-Nagy, F. R. Cross, B. Novak e J. J. Tyson. Integrative analysis of cell cycle control in budding yeast. Molecular Biology of the Cell, 15(8):3841-3862. Citado na pág. 15

Chen et al.(2002) Y. Chen, V. Kamat, E. R. Dougherty, M. L. Bittner, P. S. Meltzer e J. M. Trent. Ratio statistics of gene expression levels and applications to microarray data analysis. Bioinformatics, 18(9):1207-1215. Citado na pág. 10

Chiang et al.(1998) S. Y. Chiang, J. C. Azizkhan e T. A. Beerman. A comparison of DNAbinding drugs as inhibitors of E2F1- and Sp1-DNA complexes and associated gene expression. Biochemistry, 37(9):3109-3115. Citado na pág. 80

Cook(1971) S. A. Cook. The complexity of theorem-proving procedures. Em Proceedings of the third annual ACM symposium on Theory of computing (STOC), páginas 151-158. Citado na pág. 36

Cross(1988) F. R. Cross. DAF1, a mutant gene affecting size control, pheromone arrest, and cell cycle kinetics of Saccharomyces cerevisiae. Molecular Cell Biology, 8. Citado na pág. 105

Das et al.(2004) P. M. Das, K. Ramachandran, J. vanWert e R. Singal. Chromatin immunoprecipitation assay. Biotechniques, 37(6):961-969. Citado na pág. 2

Datta e Dougherty(2007) A. Datta e E. R. Dougherty. Introduction to Genomic Signal Processing with Control. CRC Press, 1 edição. ISBN 0849371988. Citado na pág. 10

DeGregori et al.(1995) J. DeGregori, T. Kowalik e Nevins J. R. Cellular targets for activation by the E2F1 transcription factor include DNA synthesis- and G1/S-regulatory genes. Molecular Cell Biology, 15(8):4215-4224. Citado na pág. 80

DeJong(2002) H. DeJong. Modeling and simulation of genetic regulatory systems: A literature review. Journal of Computational Biology, 9(1):67-103. Citado na pág. 14, 27

Devijver e Kittler(1982) P. A. Devijver e J. Kittler. Pattern Recognition: A Statistical Approach. Prentice Hall. Citado na pág. 33

D'Haeseleer et al.(1999) P. D'Haeseleer, S. Liang e R. Somogyi. Gene expression data analysis and modeling. Em Proceedings of the Pacific Symposium on Biocomputing, páginas 1-34. Citado na pág. 3

D'Haeseleer et al.(2000) P. D'Haeseleer, S. Liang e R. Somogyi. Genetic network inference: from co-expression clustering to reverse engineering. Bioinformatics, 16(8):707-726. Citado na pág. 29 
Di Bernardo et al.(2004) D. Di Bernardo, T. S. Gardner e J. J. Collins. Robust identification of large genetic networks. Pacific Symposium on Biocomputing, páginas 486-497. Citado na pág. 28

Dougherty e Xiao(2006) E. R. Dougherty e Y. Xiao. Design of probabilistic Boolean networks under the requirement of contextual data consistency. IEEE Transactions on Signal Processing, 54(9):3603-3613. Citado na pág. 29

Dougherty et al.(2000) E. R. Dougherty, S. Kim e Y. Chen. Coefficient of determination in nonlinear signal processing. Signal Processing, 80:2219-2235. Citado na pág. 3, 29, 63

Dougherty et al.(2010) E. R. Dougherty, R. Pal, X. Qian, M. L. Bittner e A. Datta. Stationary and structural control in gene regulatory networks: basic concepts. International Journal of Systems Science, 41(1):5-16. Citado na pág. 107

Dougherty et al.(1995) J. Dougherty, R. Kohavi e M. Sahami. Supervised and unsupervised discretization of continuous features. Em Proceedings of the Twelfth International Conference on Machine Learning, páginas 194-202. Citado na pág. 12

Duda et al.(2001) R. Duda, P. Hart e D. Stork. Pattern Classification (2nd Edition). WileyInterscience, 2 edição. ISBN 0471056693. Citado na pág. 30

Ellson et al.(2002) J Ellson, E Gansner, L Koutsofios, S North e G Woodhull. Graphviz - open source graph drawing tools. Em Petra Mutzel, Michael Junger e Sebastian Leipert, editors, Graph Drawing, volume 2265 of Lecture Notes in Computer Science, chapter 57, páginas 594597. Springer Berlin / Heidelberg. ISBN 978-3-540-43309-5. Citado na pág. 92, 93

Emmert-Streib e Dehmer(2008) F. Emmert-Streib e M. Dehmer. Analysis of Microarray Data: A Network-Based Approach. WILEY-VCH. Citado na pág. 26, 27

Espinosa-Soto et al.(2004) C. Espinosa-Soto, P. Padilla-Longoria e E. R. Alvarez-Buylla. A gene regulatory network model for Cell-Fate determination during arabidopsis thaliana flower development that is robust and recovers experimental gene expression profiles. Plant Cell, 16 (11):2923-2939. Citado na pág. 2

Fagan et al.(1994) R Fagan, K J Flint e N Jones. Phosphorylation of e2f-1 modulates its interaction with the retinoblastoma gene product and the adenoviral e4 19 kda protein. Cell, 78(5):799-811. Citado na pág. 95

Faith et al.(2007) J. J. Faith, B. Hayete, J. T. Thaden, I. Mogno, J. Wierzbowski, G. Cottarel, S. Kasif, J. J. Collins e T. S. Gardner. Large-Scale Mapping and Validation of Escherichia coli Transcriptional Regulation from a Compendium of Expression Profiles. PLoS Biology, 5(1): e8+. Citado na pág. 26

Friedman et al.(1999) N. Friedman, K. Murphy e S. Russell. Learning the structure of dynamic probabilistic networks. Em 15th Annual Conference on Uncertainty in Artificial Intelligence, páginas 139-147. Morgan Kaufmann. Citado na pág. 16, 17

Friedman et al.(2000) N. Friedman, M. Linial, I. Nachman e D. Peer. Using Bayesian networks to analyze expression data. Journal of Computational Biology, 7(6):601-620. Citado na pág. 2, 16

Fuente et al.(2004) A. Fuente, N. Bing, I. Hoeschele e P. Mendes. Discovery of meaningful associations in genomic data using partial correlation coefficients. Bioinformatics, 20(18): 3565-3574. Citado na pág. 28 
Fujita et al.(2009) A. Fujita, J. R. Sato, K. Kojima, L. R. Gomes, M. Nagasaki, M. C. Sogayar e S. Miyano. Identification and quantification of granger causality between gene sets. Journal of Bioinformatics and Computational Biology, páginas 679-701. Citado na pág. 29

Gardner e Faith(2005) T. S. Gardner e J. J. Faith. Reverse-engineering transcription control networks. Physics of Life Reviews, 2. Citado na pág. 14

Ghaffari et al.(2010) N. Ghaffari, I. Ivanov, X. Qian e E. R. Dougherty. A CoD-based reduction algorithm preserving the effects of stationary control policies. Bioinformatics, 26(12):15561563. Citado na pág. 107

Ghaffari et al.(2011) N. Ghaffari, I. Ivanov, X. Qian e E. R. Dougherty. A CoD-based stationary control policy for intervening in large gene regulatory networks. BMC Bioinformatics, 12 ((Suppl 10):S10):1556-1563. Citado na pág. 107

Goodwin(1963) B. C. Goodwin. Temporal Organization in Cells; A Dynamic Theory of Cellular Control Process. Academic Press. Citado na pág. 2, 14

Hache et al.(2009) H. Hache, H. Lehrach e R. Herwig. Reverse engineering of gene regulatory networks: A comparative study. EURASIP Journal on Bioinformatics and Systems Biology, 2009. Citado na pág. 2, 13, 14, 15, 27

Hashimoto et al.(2003) R. F. Hashimoto, E. R. Dougherty, M. Brun, Z. Zhou, M. L. Bittner e J. M. Trent. Efficient selection of feature sets possessing high coefficients of determination based on incremental determinations. Signal Processing, 83:695-712. Citado na pág. 3, 64

Hashimoto et al.(2004) R. F. Hashimoto, S. Kim, I. Shmulevich, W. Zhang, M. L. Bittner e E. R. Dougherty. Growing genetic regulatory networks from seed genes. Bioinformatics, 20 ? (8):1241-1247. Citado na pág. 3, 97

Hecker et al.(2009) M. Hecker, S. Lambeck, S. Toepfer, E. van Someren e E. Guthke. Gene regulatory network inference: Data integration in dynamic models - a review. BioSystems, 96: 86-103. Citado na pág. $2,13,16,28$

Herzberg et al.(2007) C. Herzberg, L. A. Weidinger, B. Dörrbecker, S. Hübner, J. Stülke e F. M. Commichau. SPINE: a method for the rapid detection and analysis of protein-protein interactions in vivo. Proteomics, 7(22):4032-4035. Citado na pág. 2

Higa e Hashimoto(2007) C. H. A. Higa e R. F. Hashimoto. Modelling yeast cell-cycle with context probabilistic boolean network. Em X-Meeting 2007 - 3rd International Conference of the Brazilian Association for Bioinformatics and Computational Biology. Citado na pág. 50

Higa et al.(2008) C. H. A. Higa, R. F. Hashimoto, R. Hirata Jr e N. S. T. Hirata. Considerations on using CoD for inference of gene regulation networks. Em X-Meeting 2008 - 4th International Conference of the Brazilian Association for Bioinformatics and Computational Biology. Citado na pág. 29,64

Higa et al.(2009a) C. H. A. Higa, R. F. Hashimoto, R. Hirata Jr, N. S. T. Hirata e C. S. Santos. Inference of gene regulatory network using temporal coefficient of determination obtained from ergodic Markov chains. Em IEEE International Workshop on Genomic Signal Processing and Statistics. Citado na pág. 29, 67

Higa et al.(2009b) C. H. A. Higa, H. Stagni e R. F. Hashimoto. Budding yeast cell cycle modeled by context-sensitive probabilistic Boolean network. Em IEEE International Workshop on Genomic Signal Processing and Statistics. Citado na pág. 49, 50 
Higa et al.(2010) C. H. A. Higa, V. H. P. Louzada e R. F. Hashimoto. Analysis of gene interactions using restricted Boolean networks and time-series data. Em M. Borodovsky, J. P. Gogarten, T. M. Przytycka e S. Rajasekaran, editors, Proceedings of the 6th Symposium on Bioinformatics Research and Applications, páginas 61-76. Springer-Verlag Berlin Heidelberg. Citado na pág. 70

Higa et al.(2011a) C. H. A. Higa, T. P. Andrade e R. F. Hashimoto. Growing seed genes from time series data and thresholded Boolean networks with perturbation. Submitted, 2011a. Citado na pág. 81

Higa et al.(2011b) C. H. A. Higa, V. H. P. Louzada, T. P. Andrade e R. F. Hashimoto. Constraint-based analysis of gene interactions using restricted Boolean networks and timeseries data. BMC Proceedings, 5(Suppl 2):S5. Citado na pág. 70, 84

Hogeweg(2011) P. Hogeweg. The Roots of Bioinformatics in Theoretical Biology. PLoS Computational Biology, 7(3):e1002021+. Citado na pág. 1

Holt et al.(2008) L. J. Holt, A. N. Krutchinsky e D. O. Morgan. Positive feedback sharpens the anaphase switch. Nature, 454(7202):353-357. Citado na pág. 81

Huang(1999) S. Huang. Gene expression profiling, genetic networks, and cellular states: an integrating concept for tumorigenesis and drug discovery. Journal of Molecular Medicine, 77 : 469-480. Citado na pág. 19, 83, 102

Huang e Ingber(2007) S. Huang e D. E. Ingber. A non-genetic basis for cancer progression and metastasis: Self-organizing attractors in cell regulatory networks. Breast Disease, 26:27-54. Citado na pág. 20

Huang et al.(2009) S. Huang, I. Ernberg e S. Kauffman. Cancer attractors: A systems view of tumors from a gene network dynamics and developmental perspective. Seminars in Cell $\mathbb{6}$ Developmental Biology, 20(7):869-876. Citado na pág. 20

IHGSC(2001) IHGSC. Initial sequencing and analysis of the human genome. Nature, 409: 860-921. Citado na pág. 1

Irons(2009) D. J. Irons. Logical analysis of the budding yeast cell cycle. Journal of Theoretical Biology, 257(4):543-559. Citado na pág. 47

Ivanov e Dougherty(2006) I. Ivanov e E. R. Dougherty. Modeling genetic regulatory networks: continuous or discrete? Journal of Biological Systems, 14(2):219-229. Citado na pág. 2

Karlebach e Shamir(2008) G. Karlebach e R. Shamir. Modelling and analysis of gene regulatory networks. Nature, 9:770-780. Citado na pág. 2, 3, 15, 18

Kastan e Bartek(2004) M. B. Kastan e J. Bartek. Cell-cycle checkpoints and cancer. Nature, 432(7015):316-323. Citado na pág. 42

Kauffman(1969) S. A. Kauffman. Metabolic stability and epigenesis in randomly constructed genetic nets. Journal of Theoretical Biology, 22(3):437-467. Citado na pág. 1, 2, 18, 20

Kauffman(1993) Stuart A. Kauffman. The Origins of Order: Self-Organization and Selection in Evolution. Oxford University Press. Citado na pág. 19, 20, 82, 83, 102

Kerr et al.(2000) M. K. Kerr, M. Martin e G. A. Churchill. Analysis of variance for gene expression microarray data. Journal of Computational Biology, 7(6):819-837. Citado na pág. 10 
Kitano(2002) H. Kitano. Systems Biology: A Brief Overview. Science, 295(5560):1662-1664. Citado na pág. 1

Koff et al.(1992) A. Koff, A. Giordano, D. Desai, K. Yamashita, J. W. Harper, S. Elledge, T. Nishimoto, D. O. Morgan, B. R. Franza e J. M. Roberts. Formation and activation of a cyclin E-cdk2 complex during the G1 phase of the human cell cycle. Science (New York, N.Y.), 257(5077):1689-1694. Citado na pág. 80, 81

Kong et al.(2000) M. Kong, E. A. Barnes, V. Ollendorff e D. J. Donoghue. Cyclin F regulates the nuclear localization of cyclin B1 through a cyclin-cyclin interaction. The EMBO Journal, 19(6):1378-1388. Citado na pág. 81

Lashkari et al.(1997) D. A. Lashkari, J. L. DeRisi, J. H. McCusker, A. F. Namath, C. Gentile, S. Y. Hwang, P. O. Brown e R. W. Davis. Yeast microarrays for genome wide parallel genetic and gene expression analysis. PNAS of the United States of America, 94(24):13057-13062. Citado na pág. 9

Lau et al.(2007) K. Y. Lau, S. Ganguli e C. Tang. Function constrains network architecture and dynamics: A case study on the yeast cell cycle boolean network. Physics Review E, 75(5): 1-9. Citado na pág. 70,75

Laubenbacher e Stigler(2004) R. Laubenbacher e B. Stigler. A computational algebra approach to the reverse engineering of gene regulatory networks. Journal of Theoretical Biology, 229(4):523-537. Citado na pág. 29

Lee et al.(2000) M. L. Lee, F. C. Kuo, G. A. Whitmore e J. Sklar. Importance of replication in microarray gene expression studies: statistical methods and evidence from repetitive cDNA hybridizations. PNAS of the United States of America, 97(18):9834-9839. Citado na pág. 10

Lee e Tzou(2009) W. P. Lee e W. S. Tzou. Computational methods for discovering gene networks from expression data. Briefings in Bioinformatics, 10(4):408-423. Citado na pág. 14, 15,16

Li et al.(2004) F. Li, T. Long, Y. Lu, Q. Ouyang e C. Thang. The yeast cell-cycle network is robustly designed. PNAS of the United States of America, 101(14):4781-4786. Citado na pág. 2, $3,41,42,43,44,45,46,47,49,50,76,82,91,96,105,106$

Li et al.(2007) S. Li, P. Brazhnik, B. Sobral e J. J. Tyson. A quantitative study of the division cycle of Caulobacter crescentus stalked cells. PLoS Computational Biology, preprint(2007): e9.eor+. Citado na pág. 15

Li et al.(2010) Y. Li, L. Liu, X. Bai, H. Cai, W. Ji, D. Guo e Y. Zhu. Comparative study of discretization methods of microarray data for inferring transcriptional regulatory networks. BMC Bioinformatics, 11(1):520+. Citado na pág. 12

Liang et al.(1998) S. Liang, S. Fuhrman e R. Somogyi. Reveal, a general reverse engineering algorithm for inference of genetic network architectures. Pacific Symposium on Biocomputing, páginas $18-29$. Citado na pág. 28

Lima(2009) L. A. Lima. Um algoritmo eficiente para o crescimento de redes sobre o grafo aleatório completo de um sistema de regulação gênica. Dissertação de Mestrado, Universidade de São Paulo. Citado na pág. 3

Locke et al.(2005) J. C. W. Locke, M. M. Southern, L. Kozma-Bognár, V. Hibberd, P. E. Brown, M. S. Turner e A. J. Millar. Extension of a genetic network model by iterative experimentation and mathematical analysis. Molecular Systems Biology, 1(1). Citado na pág. 15 
Lopes(2011) F. M. Lopes. Redes complexas de expressão gênica: sintese, identificação, análise e aplicações. Tese de Doutorado, Universidade de São Paulo. Citado na pág. 29

Lopes et al.(2008) F. M. Lopes, R. M. Cesar-Jr e L. F. Costa. Agn simulation and validation model. Em Advances in Bioinformatics and Computational Biology, Lecture Notes in Bioinformatics, páginas 169-173. Citado na pág. 29

Lopes et al.(2011) F. M. Lopes, R. M. Cesar-Jr. e L. F. Costa. Gene Expression Complex Networks: synthesis, identification, and analysis. Journal of Computational Biology, 18(10): 1353-1367. Citado na pág. 29

Mackworth(1977) A. K. Mackworth. Consistency in networks of relations. Artificial Intelligence, 8(1):99-118. Citado na pág. 40

MacQueen(1967) J. B. MacQueen. Methods for classification and analysis of multivariate observations. Em Proceedings of the 5th Berkley Symposium on Mathematical Statistics and Probability, páginas 281-297. University of California Press. Citado na pág. 12

Marbach et al.(2010) D. Marbach, R. J. Prill, T. Schaffter, C. Mattiussi, D. Floreano e G. Stolovitzky. Revealing strengths and weaknesses of methods for gene network inference. PNAS of the United States of America, 107(14):6286-6291. Citado na pág. 107

Margolin et al.(2006) A. A. Margolin, I. Nemenman, K. Basso, C. Wiggins, G. Stolovitzky, R. Dalla Favera e A. Califano. ARACNE: an algorithm for the reconstruction of gene regulatory networks in a mammalian cellular context. BMC Bioinformatics, 7 Suppl 1. Citado na pág. 14, 26

Marill e Green(1963) T Marill e D Green. On the effectiveness of receptors in recognition systems. IEEE Trans. Inf. Theory, 9(1):917-922. Citado na pág. 32

Marriott e Stuckey(1998) K. Marriott e P. J. Stuckey. Programming with Constraints: An Introduction. The MIT Press. Citado na pág. 40

Marshall et al.(2007) S. Marshall, L. Yu, Y. Xiao e E. R. Dougherty. Inference of probabilistic Boolean networks from a single observed temporal sequence. EURASIP Journal on Bioinformatics and Systems Biology, 2007. Citado na pág. 29

Martins-Jr(2008) D. C. Martins-Jr. Seleção de características e predição intrinsecamente multivariada em identificação de redes de regulação gênica. Tese de Doutorado, Universidade de São Paulo. Citado na pág. 29

Martins-Jr et al.(2006) D. C. Martins-Jr, R. C. Cesar-Jr e J. Barrera. W-operator window design by minimization of mean conditional entropy. Pattern Analysis $\mathscr{G}$ Applications, páginas 139-153. Citado na pág. 29

Martins-Jr et al.(2009) D. C. Martins-Jr, E. A. Oliveira, P. J. S. Silva, R. F. Hashimoto e R. M. Cesar-Jr. Revealing temporal genetic regulatory networks from steady-state distributions. Em IEEE International Workshop on Genomic Signal Processing and Statistics. Citado na pág. 69, 106

Murray(1994) A. Murray. Cell cycle checkpoints. Current Opinion in Cell Biology, 6:872-876. Citado na pág. 42

Nakariyakul e Casasent(2009) S. Nakariyakul e D. P. Casasent. An improvement on floating search algorithms for feature subset selection. Pattern Recognition, 42(9):1932-1940. Citado na pág. $32,34,35,85,106$ 
Needham et al.(2007) C. J. Needham, J. R. Bradford, A. J. Bulpitt e D. R. Westhead. A primer on learning in Bayesian networks for computational biology. PLoS Computational Biology, 3 (8):e129+. Citado na pág. 28

Ohta et al.(2002) S. Ohta, Y. Shiomi, K. Sugimoto, C. Obuse e T. Tsurimoto. A proteomics approach to identify proliferating cell nuclear antigen (PCNA)-binding proteins in human cell lysates. Identification of the human CHL12/RFCs2-5 complex as a novel PCNA-binding protein. Journal of Biological Chemistry, 277(43):40362-40367. Citado na pág. 81

Owens et al.(2007) J. D. Owens, D. Luebke, N. Govindaraju, M. Harris, J. Krüger, A. Lefohn e T. J. Purcell. A Survey of General-Purpose Computation on Graphics Hardware. Computer Graphics Forum, 26(1):80-113. Citado na pág. 107

Peña et al.(2005) J.M. Peña, J. Björkegren e J. Tegnér. Growing Bayesian network models of gene networks from seed genes. Bioinformatics, 21(Suppl. 2):ii224-ii229. Citado na pág. 3

Pudil et al.(1994) P Pudil, J Novovicova e J Kittler. Floating search methods in FeatureSelection. Pattern Recognition Letters, 15(11):1119-1125. Citado na pág. 33

Quackenbush(2002) J. Quackenbush. Microarray data normalization and transformation. Nature Genetics, 32 Suppl:496-501. Citado na pág. 11

Rahbari et al.(2009) R. Rahbari, T. Sheahan, V. Modes, P. Collier, C. Macfarlane e R. M. Badge. A novel L1 retrotransposon marker for HeLa cell line identification. Biotechniques, 46 (4):277-284. Citado na pág. 77

Roeder(1996) R. G. Roeder. The role of general initiation factors in transcription by RNA polymerase II. Trends in Biochemical Sciences, 21(9):327-335. Citado na pág. 86

Ross(2007) S. M. Ross. Introduction to Probability Models. Academic Press, 9 edição. Citado na pág. 54,66

Russell e Norvig(2002) S. Russell e P. Norvig. Artificial Intelligence: A Modern Approach (2nd Edition). Prentice Hall, 2 edição. ISBN 0137903952. Citado na pág. 36, 37, 38, 40

Savageau(1969) M. A. Savageau. Biochemical systems analysis. I. Some mathematical properties of the rate law for the component enzymatic reactions. Journal Theoretical Biology, 25 (3):365-369. Citado na pág. 14

Savageau(1970) M. A. Savageau. Biochemical Systems Analysis. Adison-Wesley. Citado na pág. 2

Schena et al.(1995) M. Schena, D. Shalon, R. W. Davis e P. O. Brown. Quantitative monitoring of gene expression patterns with a complementary DNA microarray. Science, 270(5235):467470. Citado na pág. 2,9

Selbach e Mann(2006) M. Selbach e M. Mann. Protein interaction screening by quantitative immunoprecipitation combined with knockdown (QUICK). Nature Methods, 3(12):981-983. Citado na pág. 2

Shalon et al.(1996) D. Shalon, S. J. Smith e P. O. Brown. A DNA microarray system for analyzing complex DNA samples using two-color fluorescent probe hybridization. Genome Research, 7(6):639-645. Citado na pág. 2 
Shanahan et al.(1999) F. Shanahan, W. Seghezzi, D. Parry, D. Mahony e E. Lees. Cyclin E associates with BAF155 and BRG1, components of the mammalian SWI-SNF complex, and alters the ability of BRG1 to induce growth arrest. Molecular and Cellular Biology, 19(2): 1460-1469. Citado na pág. 80, 81

Shmulevich e Zhang(2002) I Shmulevich e W. Zhang. Binary analysis and optimization-based normalization of gene expression data. Bioinformatics, 18(4):555-565. Citado na pág. 18

Shmulevich et al.(2002a) I. Shmulevich, E. R. Dougherty, S. Kim e W. Zhang. Probabilistic Boolean networks: a rule-based uncertainty model for gene regulatory networks. Bioinformatics, 18(2):261-274. Citado na pág. 2, 24, 25

Shmulevich et al.(2002b) I. Shmulevich, E. R. Dougherty e W. Zhang. From Boolean to probabilistic Boolean networks as models of genetic regulatory networks. Proceedings of the IEEE, 90(11):1778-1792. Citado na pág. 18, 19, 20, 24, 82

Shmulevich et al.(2002c) I. Shmulevich, E. R. Dougherty e W. Zhang. Gene perturbation and intervention in probabilistic Boolean networks. Bioinformatics, 18(10):1319-1331. Citado na pág. 22,23

Sima et al.(2009) C. Sima, J. Hua e S. Jung. Inference of Gene Regulatory Networks Using Time-Series Data: A Survey. Current Genomics, 10(6):416-429. Citado na pág. 11, 63

Spellman et al.(1998) P. T. Spellman, G. Sherlock, M. Q. Zhang, V. R. Iyer, K. Anders, M. B. Eisen, P. O. Brown, D. Botstein e B. Futcher. Comprehensive identification of cell cycleregulated genes of the yeast Saccharomyces cerevisiae by microarray hybridization. Molecular Biology of the Cell, 9(12):3273-3297. Citado na pág. 42

Szallasi et al.(2006) Zoltan Szallasi, Jörg Stelling e Vipul Periwal. System modeling in cell biology : from concepts to nuts and bolts. MIT Press. ISBN 0262195488. Citado na pág. 15

Tack(2009) G. Tack. Constraint propagation: models, techniques, implementation. Tese de Doutorado, Universität des Saarlandes. Citado na pág. 90

Trepode et al.(2007) N. W. Trepode, H. A. Armelin, M. Bittner, J. Barrera, M. D. Gubitoso e R. F. Hashimoto. A robust structural pgn model for control of cell-cycle progression stabilized by negative feedbacks. EURASIP Journal on Bioinformatics and Systems Biology, 2007:11 pages. Citado na pág. 17

Tsang(1993) E Tsang. Foundations of Constraint Satisfaction. Academic Press. Citado na pág. 40

Tseng et al.(2001) G. C. Tseng, M. K. Oh, L. Rohlin, J. C. Liao e W. H. Wong. Issues in cDNA microarray analysis: quality filtering, channel normalization, models of variation and assessment of gene effects. Nucleic Acids Research, 29(12):2549-2557. Citado na pág. 11

Tu et al.(2002) Y. Tu, G. Stolovitzky e U. Klein. Quantitative noise analysis for gene expression microarray experiments. PNAS of the United States of America, 99(22):14031-14036. Citado na pág. 10

Vahedi et al.(2009) G. Vahedi, I. Ivanov e E. R. Dougherty. Inference of Boolean networks under constraint on bidirectional gene relationships. IET Systems Biology Journal, 3:191-202. Citado na pág. 29

Vajda et al.(1950) S Vajda, C E Shannon e W Weaver. The mathematical theory of communication. The Mathematical Gazette, 34(310):312+. Citado na pág. 83 
Venter(2001) J. C. Venter. The sequence of the human genome. Science, 291:1304-1351. Citado na pág. 1

Vilela et al.(2008) M. Vilela, I. C. Chou, S. Vinga, A. T. T. Vasconcelos, E. O. Voit e J. S. Almeida. Parameter optimization in S-system models. BMC Systems Biology, 2(1). Citado na pág. 15

Waddington(1972) C. H. Waddington. Towards a Theoritical Biology. Edinburgh University Press. Citado na pág. 1

Wang et al.(2009) Z. Wang, M. Gerstein e M. Snyder. RNA-Seq: a revolutionary tool for transcriptomics. Nature Reviews Genetics, 10(1):57-63. Citado na pág. 2

Werbos(1990) P. J. Werbos. Backpropagation through time: what it does and how to do it. Proceedings of the IEEE, 78(10):1550-1560. Citado na pág. 15, 27

Werhli et al.(2006) A. V. Werhli, M. Grzegorczyk e D. Husmeier. Comparative evaluation of reverse engineering gene regulatory networks with relevance networks, graphical gaussian models and bayesian networks. Bioinformatics, 22(20). Citado na pág. 14, 27

Whitfield et al.(2002) M. L. Whitfield, G. Sherlock, A. J. Saldanha, J. I. Murray, C. A. Ball, K. E. Alexander, J. C. Matese, C. M. Perou, M. M. Hurt, P. O. Brown e D. Botstein. Identification of genes periodically expressed in the human cell cycle and their expression in tumors. Molecular biology of the cell, 13(6):1977-2000. Citado na pág. 77, 79, 95

Whitney(1971) A. W. Whitney. A direct method of nonparametric measurement selection. IEEE Trans. Comput., 20(9):1100-1103. Citado na pág. 32

Wikipedia(2011a) Wikipedia. Dna microarray — Wikipedia, the free encyclopedia, 2011a. URL http://en.wikipedia.org/wiki/DNA_microarray. [Online; accessed 2-October-2011]. Citado na pág. 11

Wikipedia(2011b) Wikipedia. RNA splicing - Wikipedia, the free encyclopedia, 2011b. URL http://en.wikipedia.org/wiki/RNA_splicing. [Online; accessed 2-October-2011]. Citado na pág. 9

Wikipedia(2011c) Wikipedia. Transcription - Wikipedia, the free encyclopedia, 2011c. URL http://en.wikipedia.org/wiki/Transcription_(genetics). [Online; accessed 2-October-2011]. Citado na pág. 8

Yang et al.(2002) Y. H. Yang, S. Dudoit, P. Luu, D. M. Lin, V. Peng, J. Ngai e T. P. Speed. Normalization for cDNA microarray data: a robust composite method addressing single and multiple slide systematic variation. Nucleic Acids Research, 30(4):e15. Citado na pág. 11

Zhang et al.(2006) Y. Zhang, M. Quian, Q. Ouyang, M. Deng, F. Li e C. Tang. Stochastic Model of Yeast Cell-Cycle Network. Physica D, 219:35-39. Citado na pág. 3, 41, 45, 46, 49, 50, $51,52,53,54,59,64,65,68,105,106$

Zhao et al.(2006) W. Zhao, E. Serpedin e E. R. Dougherty. Inferring gene regulatory networks from time series data using the minimum description length principle. Bioinformatics, 22(17): 2129-2135. Citado na pág. 29

Zhao et al.(2008) W. Zhao, E. Serpedin e E. R. Dougherty. Inferring Connectivity of Genetic Regulatory Networks Using Information-Theoretic Criteria. IEEE Transactions on Computational Biology and Bioinformatics, 5(2):262-274. Citado na pág. 26

Zheng et al.(2007) M. Zheng, L. O. Barrera, B. Ren e Y. N. Wu. ChIP-chip: Data, model, and analysis. Biometrics, 63(3):787-796. Citado na pág. 2 


\section{Índice Remissivo}

algoritmos de inferência

equações diferenciais ordinárias, 27

modelos gráficos Gaussianos, 26

redes genéticas probabilísticas, 28

algoritmos de inferência, 25

redes de relevância, 25

redes Bayesianas, 27

redes Booleanas, 28

redes neurais, 26

amostragem, 82, 83

atrator, 19, 58, 83

bacia de atração, 19, 83

Ben Hesper, 1

bikmeans, 12

Bill Clinton, 1

biologia sistêmica, 1

$\mathrm{C}++, 89$

cadeia de Markov, 45, 49, 69

cadeia de Markov não homogênea, 50

checkpoint, 42

ciclo celular, 41, 49

CoD, 28

CoD estacionário, 64

CoD temporal, 65

coeficiente de determinação, 28, 64

conectividade, 18,82

conexão determinada, 75

conexão parcialmente determinada, 75

Conrad Hal Waddington, 1

consistência, 67, 70, 85

contexto, 49

cPBN, 50

Craig Venter, 1

CSP, 35, 89

csp, 69

dados biológicos, 77

dados artificiais, 76, 90

dados biológicos, 93

diagrama de transição de estados, 19, 95, 96 discretização, 11

distribuição estacionária, 46, 50

DNA, 8

entropia, 28, 83, 87, 88, 95, 96

erro de Bayes, 64

expressão gênica, 8

microarrays, 9

falso negativo, 90

falso positivo, 90

fluxo, 54

FPR, 90

Francis Collins, 1

função critério, 85

Gecode, 89

gene hub, 82, 84

gráfico de barras, 75

HeLa, 77, 93

Henrietta Lacks, 77

Hiroaki Kitano, 1

IFFS, 85, 88

inferência, 63, 81

input, 20

kmeans, 12

levedura, 41

matriz de confusão, 90

microarray, 10, 77

Minizinc, 89

modelagem, 49

modelos de GRN

equações diferenciais ordinárias, 14

redes genéticas probabilísticas, 17

modelos de GRN, 13

modelos gráficos Gaussianos, 14

redes Bayesianas, 15

redes de relevância, 14 
redes neurais, 15

Paulien Hogeweg, 1

perturbação, 22

probabilidade de fluxo, 53, 66

pthreads, 90

rank, $75,76,80$

reconhecimento de padrões, 29

redes Booleanas, 18

BN com perturbação, 22

BN com limiar, 20

PBN, 23

ROC, 91

SBS, 88

scale-free, 83

seleção de características, 30

IFFS, 33

SBS, 32

SFFS, 32

SFS, 32

semente, $3,81,85,88$

SFS, 88

singleton, 19, 96

splicing, 9

Stuart Kauffman, 1

taxa de falso positivo, 90

taxa de verdadeiro positivo, 90

TPR, 90

transcrição, 8

verdadeiro negativo, 90

verdadeiro positivo, 90 